\title{
Design of an electron-withdrawing benzonitrile ligand for Ni-catalyzed cross- coupling involving tertiary nucleophiles
}

\author{
L. Reginald Mills, Racquel K. Edjoc, and Sophie A. L. Rousseaux* \\ Davenport Research Laboratories, Department of Chemistry, University of Toronto \\ 80 St. George St., Toronto, ON, M5S 3H6 \\ *sophie.rousseaux@utoronto.ca
}

\section{Supporting Information: Experimental Data}

\section{Table of contents}

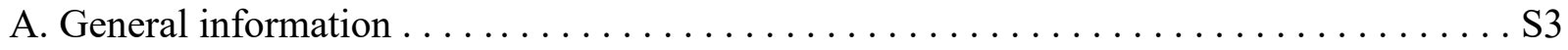

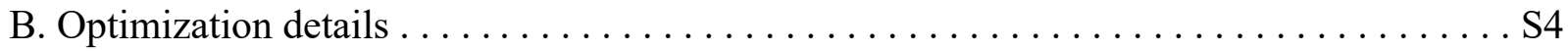

Table S1. Evaluation of ligands . . . . . . . . . . . . . . . . . S5

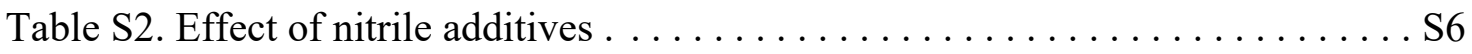

Table S3. Evaluation of transnitrilation time using $\mathrm{PhMgBr} \cdot \mathrm{LiBr} \ldots \ldots \ldots \ldots \mathrm{S} 6$

Table S4. Evaluation of Grignard reagents for transnitrilation . . . . . . . . . . S7

Table S5. Evaluation of solvent and additives . . . . . . . . . . . . S8

Table S6. Evaluation of Ni sources $\ldots \ldots \ldots \ldots \ldots \ldots \ldots \ldots \ldots \ldots \ldots \ldots$

C. Preparation of benzonitrile ligands . . . . . . . . . . . . . . . . . . . . . S10

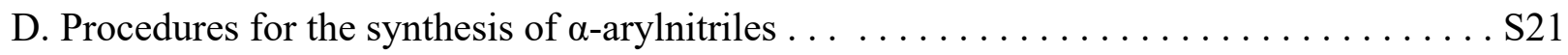

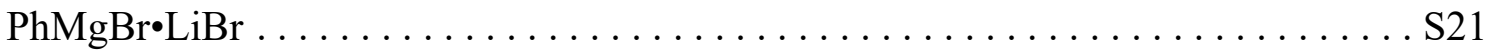

Graphical Procedure for preparation of $\mathrm{PhMgBr} \cdot \mathrm{LiBr} \ldots \ldots \ldots \ldots \ldots \ldots . \mathrm{S} 21$

General Procedure A: Preparation of $\alpha$-arylnitriles (2) from malononitriles (4) . . . S24

Graphical procedure for decyanation-metalation (General Procedure A, Step 1) . . . S25

Graphical procedure for Ni-catalyzed $\alpha$-arylation (General Procedure A, Step 2) . . . S26

Table S7. Representative unsuccessful substrates . . . . . . . . . . . . . . . . . S29

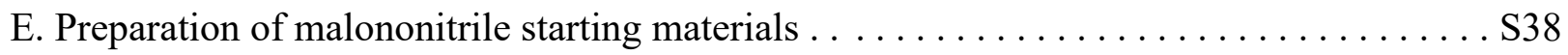


General Procedure B: Preparation of malononitrile starting materials . . . . . . . S38

F. Preparation of aryl iodide starting materials $\ldots \ldots \ldots \ldots \ldots \ldots \ldots \ldots \ldots$

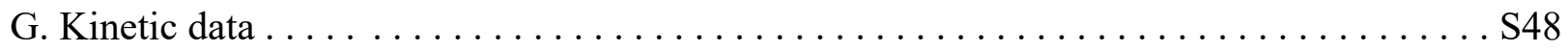

H. Hammett study with respect to $4-\mathrm{X}_{-}-\mathrm{C}_{6} \mathrm{H}_{4} \mathrm{I} \ldots \ldots \ldots \ldots \ldots \ldots \ldots \ldots \ldots \ldots \ldots \ldots \ldots \ldots \ldots \ldots$

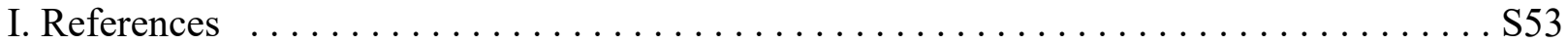

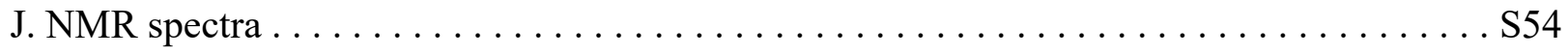




\section{A. General information}

Unless otherwise noted, all reactions were set up on benchtop and run under Ar or $\mathrm{N}_{2}$ using flame-dried glassware and anhydrous solvents. PhMe and THF were purchased as HPLC-grade (inhibitor-free) from Caledon or Sigma-Aldrich and were dried using a PureSolv MD 5 solvent purification system. PhMe used for nickel-catalyzed arylation chemistry was degassed by sonicating under vacuum for $15 \mathrm{~min}$ prior to use. THF used for decyanation and nickel-catalyzed arylation chemistry was dried over activated $3 \AA$ molecular sieves for $3 \mathrm{~d}$ before use, and was stored over sieves in a Schlenk flask sealed with a glass stopper and vacuum grease. $\mathrm{NiCl}_{2}(\mathrm{dme})$ was prepared from $\mathrm{NiCl}_{2}$ and ethylene glycol dimethyl ether ${ }^{1}$ and was stored in a glovebox. $\mathrm{NiCl}_{2}(\mathrm{PhCN})_{4}$ was prepared from $\mathrm{NiCl}_{2}$ and $\mathrm{PhCN} .{ }^{2}$ A Doyle ligand was prepared according to the literature procedure. ${ }^{3}$ Lithium bromide was purchased as anhydrous-grade from SigmaAldrich and was stored in a glovebox. Amino alcohols were prepared from the corresponding amino acid using $\mathrm{NaBH}_{4}$ and $\mathrm{I}_{2}{ }^{4}$ All other commercial reagents and starting materials were used as-is. Compounds were purified by flash column chromatography using SiliCycle SilicaFlash P60 silica gel. The 8- and 16-mL culture tubes used for reactions were purchased from Fisher Scientific (catalogue nos. 14-957-76A and 14-959-35A) and were sealed using size 19 rubber septa and electrical tape.

GC-MS data was obtained on a Shimadzu GCMS-QP2010 SE; yields represent peak areas calibrated against each compound's response factor relative to $n$-dodecane as internal standard. NMR spectra were recorded on Varian MercuryPlus $400 \mathrm{MHz}$ or Bruker AvanceIII $400 \mathrm{MHz}$ spectrometers. TLC samples were run on EMD Millipore TLC Silica gel $60 \mathrm{~F}_{254}$ plates and were visualized by UV or by staining with $\mathrm{KMnO}_{4}$, phosphomolybdic acid (PMA), or $p$-anisaldehyde stains. Melting points were obtained on a Fisher-Johns Melting Point Apparatus. High-resolution mass spectra (HRMS) were recorded on a JEOL AccuTOF JMS-T1000LV mass spectrometer equipped with a Direct Analysis in Real Time (DART) ion source. 


\section{B. Optimization details}

Procedure for optimization: Arylation optimization reactions were performed on 0.10-mmol according to General Procedure A (see section D) using the appropriate reaction components with the modification that (1-cyano-1-phenylethyl)magnesium bromide (1) was prepared as a stock solution in excess from $\alpha$-methylbenzyl cyanide and $\mathrm{PhMgBr} \bullet \mathrm{LiBr}$.

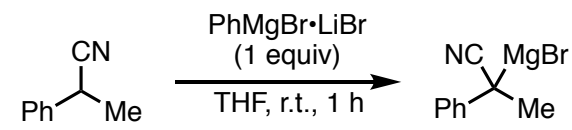

(1-Cyano-1-phenylethyl)magnesium bromide (1) from $\alpha$-methylbenzyl cyanide (for use during optimization of the $\alpha$-arylation reaction): From $\alpha$-methylbenzyl cyanide, nitrile $\alpha$ anion was prepared according to General Procedure A (Step 1) (see Section D) with the modification that deprotonation of $\alpha$-methylbenzyl cyanide was achieved at r.t. Stock solution of nitrile $\alpha$-anion was generally prepared in excess (e.g., $1.0 \mathrm{mmol}$ ) to be used for several arylation reactions, and was prepared daily and immediately before use. To a flame-dried 16-mL culture tube with a stir bar was added $\alpha$-methylbenzyl cyanide $(0.13 \mathrm{~g}, 1.0 \mathrm{mmol}, 1.0$ equiv). For a desired stock solution concentration of $0.60 \mathrm{M}$, the required solution volume was calculated to be $1.67 \mathrm{~mL}$. The required amount of $\mathrm{PhMgBr} \cdot \mathrm{LiBr}$ was calculated to be $0.78 \mathrm{~mL}(0.78 \mathrm{~mL}$ of a $1.28 \mathrm{M}$ solution in THF, $1.0 \mathrm{mmol}, 1.0$ equiv), and the required amount of additional THF to achieve a total volume of $1.67 \mathrm{~mL}$ was calculated to be $0.89 \mathrm{~mL}(1.67-0.78=0.89 \mathrm{~mL})$. Thus, THF $(0.89 \mathrm{~mL})$ was added, followed by $\mathrm{PhMgBr} \cdot \mathrm{LiBr}(0.78 \mathrm{~mL}$ of a $1.28 \mathrm{M}$ solution in THF, $1.0 \mathrm{mmol}, 1.0$ equiv) (total reaction volume $=1.67 \mathrm{~mL}, 0.60 \mathrm{M}$ ). The reaction was stirred at r.t. for $1 \mathrm{~h}$ to yield the $\alpha$-magnesiated nitrile as a $0.60 \mathrm{M}$ solution in THF. ${ }^{13} \mathrm{C} \mathrm{NMR}$ analysis of the $\alpha$-metalated nitrile revealed it to have both carbon-bound and nitrogen-bound character, consistent with characterization of a related magnesiated nitrile ${ }^{5}{ }^{13} \mathbf{C}\left\{{ }^{1} \mathbf{H}\right\} \mathbf{N M R}(125 \mathrm{MHz}$, THF, 298 K): 148.10, 128.05, 127.28, 117.00, 112.38, 34.66, 13.20 ppm. 
Table S1. Evaluation of ligands
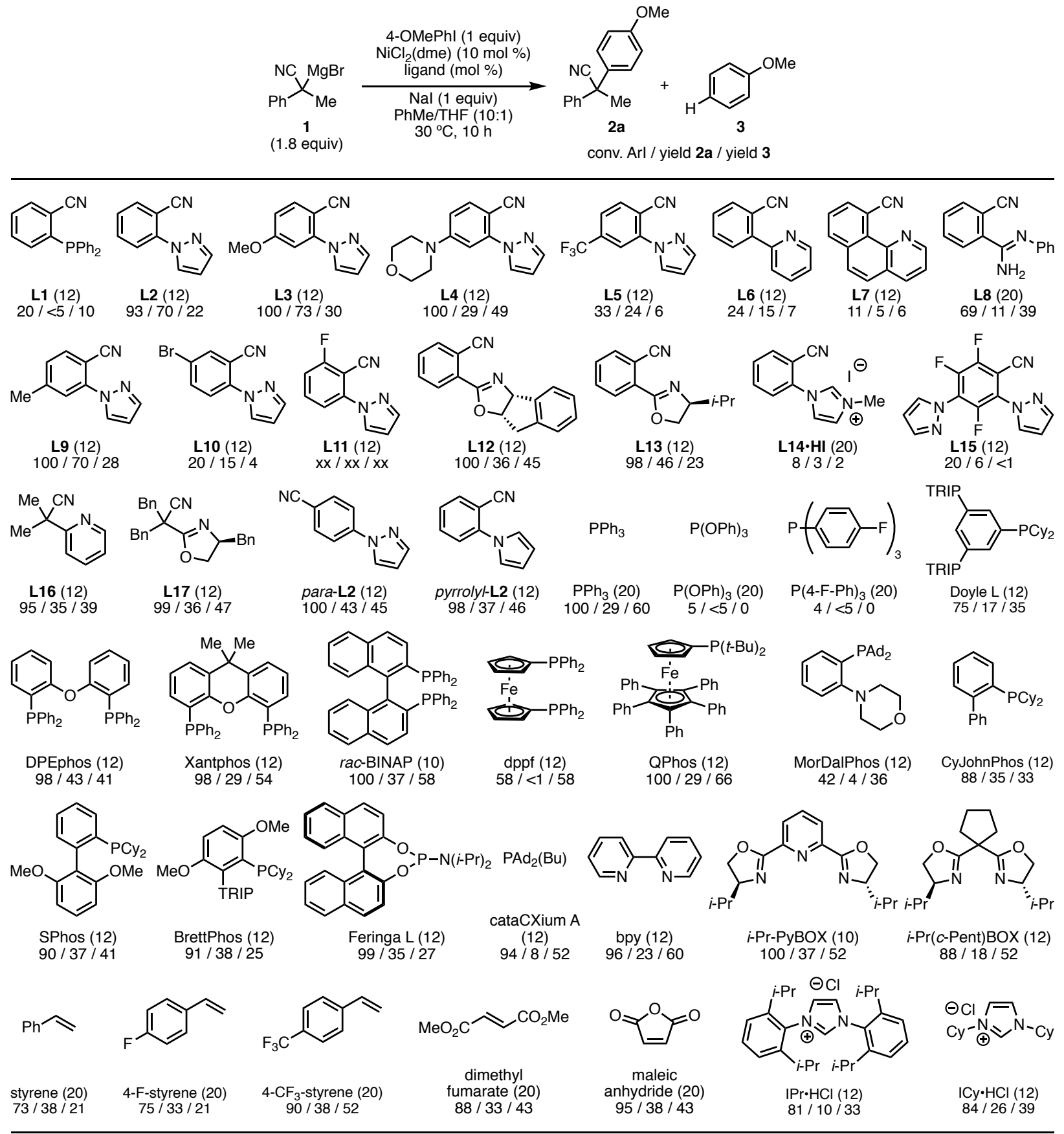

Reactions performed on 0.10-mmol scale. Conversion and yields determined by GC-MS using $n$-dodecane as an internal standard. TRIP $=2,4,6$-triisopropylphenyl. 
Table S2. Effect of nitrile additives

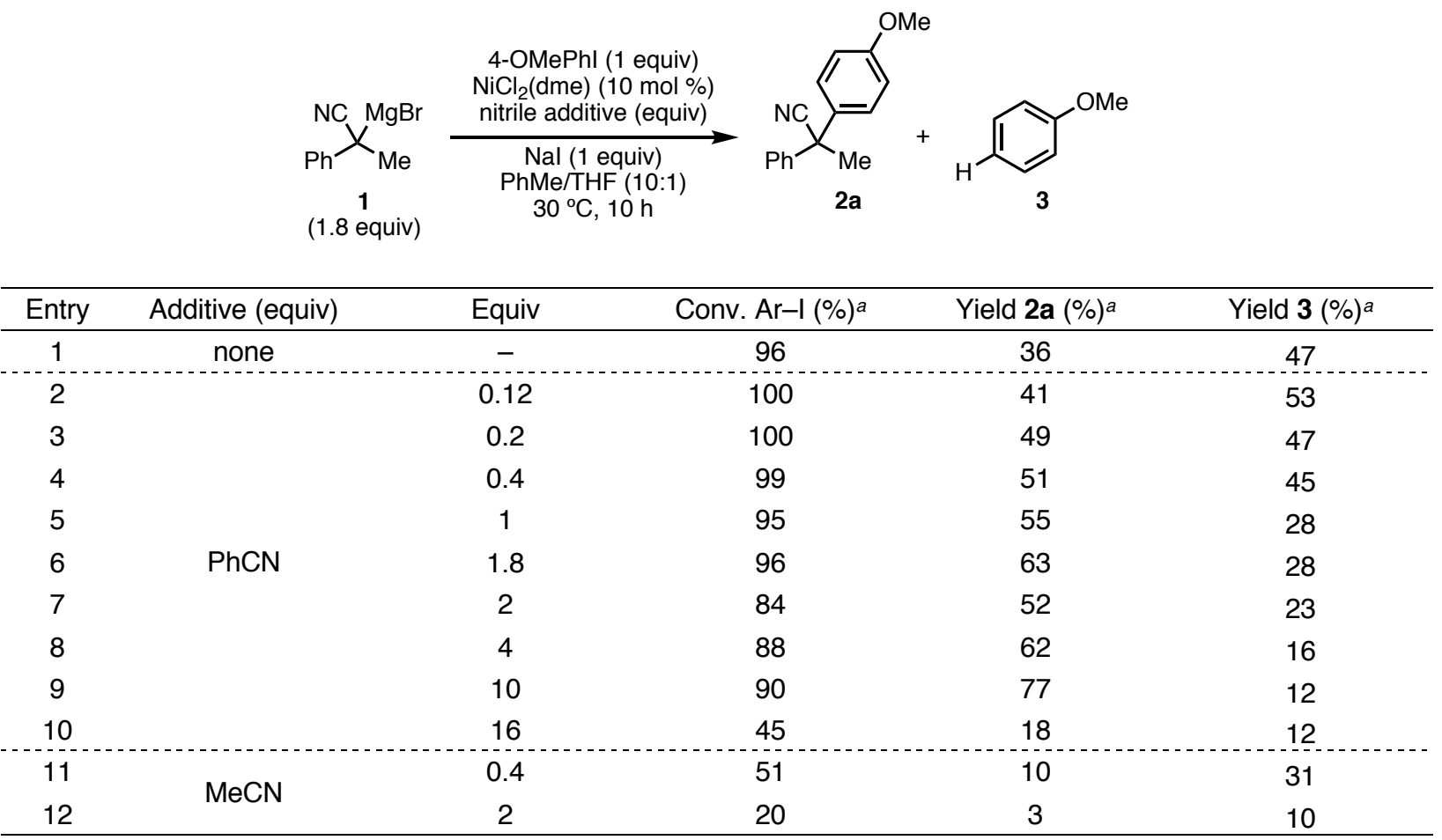

aDetermined by GC-MS using dodecane as an internal standard.

Table S3. Evaluation of transnitrilation time using $\mathrm{PhMgBr} \cdot \mathrm{LiBr}$

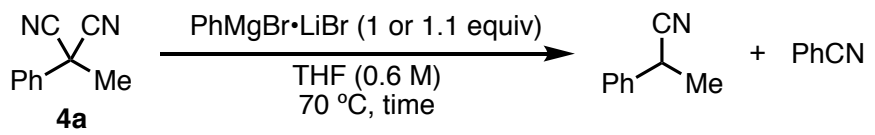

\begin{tabular}{|c|c|c|c|c|c|}
\hline Entry & Equiv $\mathrm{PhMgBr} \cdot \mathrm{LiBr}$ & Time (min) & $\begin{array}{c}\text { Conversion } 4 \mathbf{a} \\
(\%)^{a}\end{array}$ & $\begin{array}{c}\text { Yield a- } \\
\text { methylbenzyl } \\
\text { cyanide }(\%)^{a}\end{array}$ & Yield $\mathrm{PhCN}(\%)^{a}$ \\
\hline \multirow{5}{*}{1} & \multirow{5}{*}{1.0} & 5 & 87 & 102 & 102 \\
\hline & & 10 & 91 & 101 & 104 \\
\hline & & 20 & 94 & 92 & 96 \\
\hline & & 30 & 99 & 103 & 104 \\
\hline & & 40 & 100 & 96 & 98 \\
\hline \multirow{5}{*}{2} & \multirow{5}{*}{1.1} & 5 & 93 & 101 & 106 \\
\hline & & 10 & 95 & 107 & 108 \\
\hline & & 20 & 98 & 94 & 104 \\
\hline & & 30 & 99 & 101 & 106 \\
\hline & & 40 & 100 & 96 & 100 \\
\hline
\end{tabular}

aDetermined by GC-MS using $n$-dodecane as internal standard. 
Table S4. Evaluation of Grignard reagents for transnitrilation

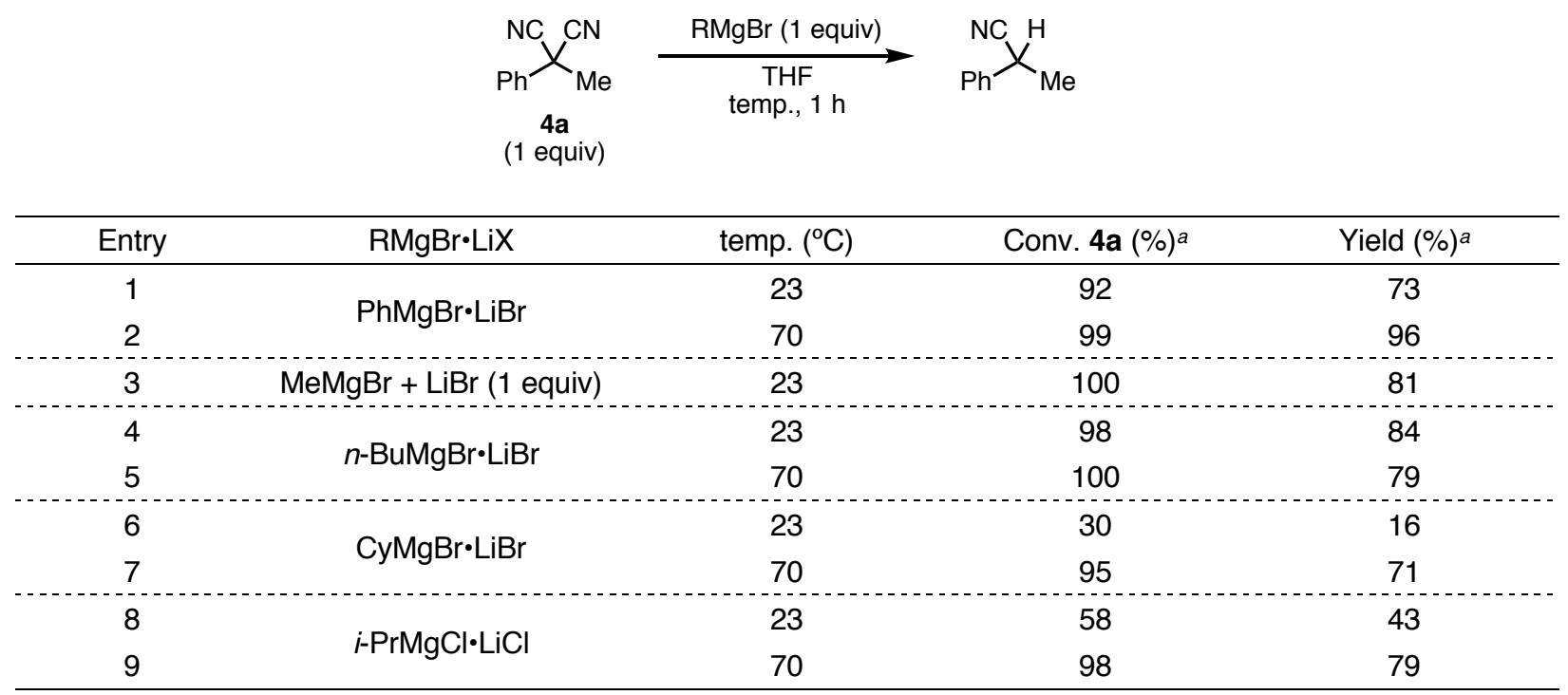

aDetermined by GC-MS using $n$-dodecane as internal standard. 
Table S5. Evaluation of solvent, additives, and $\mathrm{PhMgBr} \bullet \mathrm{LiBr}$ equiv

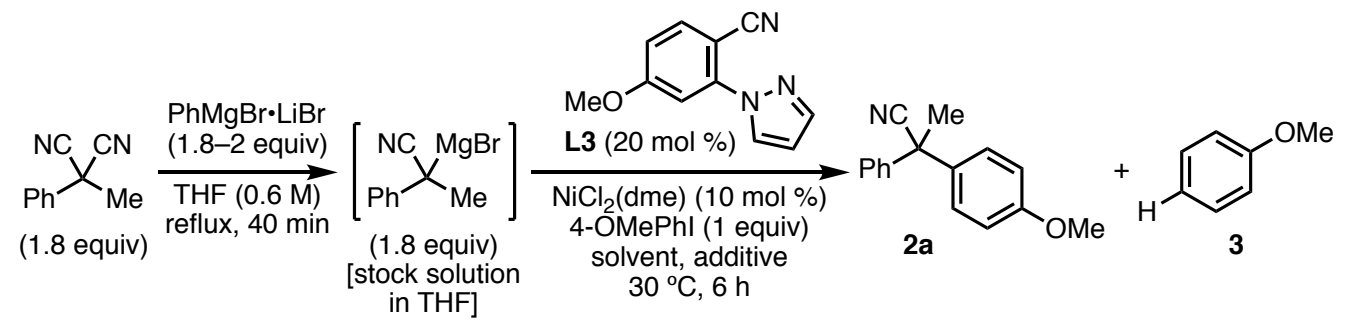

\begin{tabular}{|c|c|c|c|c|c|c|}
\hline Entry & $\begin{array}{c}\text { Equiv } \\
\mathrm{PhMgBr} \cdot \mathrm{LiBr}\end{array}$ & Solvent $(\mathrm{mL})$ & Additive & $\begin{array}{c}\text { Conv. Ar-I } \\
(\%)^{a}\end{array}$ & $\begin{array}{c}\text { Yield 2a } \\
(\%)^{a}\end{array}$ & $\begin{array}{c}\text { Yield } 3 \\
(\%)^{a}\end{array}$ \\
\hline 1 & 1.80 & $\mathrm{PhMe} / \mathrm{THF}(1.2: 0.3)$ & $\mathrm{Nal}$ & 85 & 53 & 19 \\
\hline 2 & 1.85 & $\mathrm{PhMe} / \mathrm{THF}(1.2: 0.3)$ & $\mathrm{Nal}$ & 99 & 57 & 26 \\
\hline 3 & 1.90 & $\mathrm{PhMe} / \mathrm{THF}(1.2: 0.3)$ & $\mathrm{Nal}$ & 99 & 58 & 28 \\
\hline 4 & 1.95 & $\mathrm{PhMe} / \mathrm{THF}(1.2: 0.3)$ & $\mathrm{Nal}$ & 45 & 22 & 16 \\
\hline 5 & 2.00 & $\mathrm{PhMe} / \mathrm{THF}(1.2: 0.3)$ & $\mathrm{Nal}$ & 18 & 9 & 5 \\
\hline 6 & 2.20 & $\mathrm{PhMe} / \mathrm{THF}(1.2: 0.3)$ & $\mathrm{Nal}$ & 6 & $<5$ & 0 \\
\hline 7 & 1.85 & $\mathrm{PhMe} / \mathrm{THF}(3.0: 0.3)$ & $\mathrm{Nal}$ & 100 & 70 & 20 \\
\hline 8 & 1.85 & $\mathrm{PhMe} / \mathrm{THF}(3.0: 0.23)$ & $\mathrm{Nal}$ & 85 & 60 & 19 \\
\hline 9 & 1.85 & $\mathrm{PhMe} / \mathrm{THF}(3.0: 0.18)$ & $\mathrm{Nal}$ & 61 & 38 & 18 \\
\hline $10^{b}$ & 1.85 & PhMe $(3.0)^{b}$ & $\mathrm{Nal}$ & 28 & 10 & 12 \\
\hline 11 & 1.85 & DMF/THF (3.0:0.3) & $\mathrm{Nal}$ & 83 & 0 & 74 \\
\hline 12 & 1.85 & $\mathrm{MeCN} / \mathrm{THF}(3.0: 0.3)$ & $\mathrm{Nal}$ & 0 & 0 & 0 \\
\hline 13 & 1.85 & $\mathrm{PhCN} / \mathrm{THF}(3.0: 0.3)$ & $\mathrm{Nal}$ & 0 & 0 & 0 \\
\hline 14 & 1.85 & 1,4-dioxane/THF (3.0:0.3) & $\mathrm{Nal}$ & 94 & 18 & 63 \\
\hline 15 & 1.85 & $\mathrm{PhCF}_{3} / \mathrm{THF}(3.0: 0.3)$ & $\mathrm{Nal}$ & 98 & 50 & 36 \\
\hline 16 & 1.85 & CPME/THF (3.0:0.3) & $\mathrm{Nal}$ & 0 & 1 & 0 \\
\hline 17 & 1.85 & THF (3.3) & $\mathrm{Nal}$ & 79 & 23 & 47 \\
\hline 18 & 1.85 & MTBE/THF (3.0:0.3) & $\mathrm{Nal}$ & 0 & 0 & 0 \\
\hline 19 & 1.85 & $p$-xylene/THF (3.0:0.3) & $\mathrm{Nal}$ & 51 & 34 & 12 \\
\hline 20 & 1.85 & $\mathrm{PhMe} / \mathrm{THF}(3.0: 0.3)$ & $\mathrm{NaCl}$ & 94 & 58 & 23 \\
\hline 21 & 1.85 & $\mathrm{PhMe} / \mathrm{THF}(3.0: 0.3)$ & $\mathrm{NaBr}$ & 89 & 57 & 24 \\
\hline 22 & 1.85 & $\mathrm{PhMe} / \mathrm{THF}(3.0: 0.3)$ & $\mathrm{KI}$ & 90 & 56 & 24 \\
\hline 23 & 1.85 & $\mathrm{PhMe} / \mathrm{THF}(3.0: 0.3)$ & TBAI & 86 & 35 & 41 \\
\hline 24 & 1.85 & $\mathrm{PhMe} / \mathrm{THF}(3.0: 0.3)$ & $\mathrm{LiCl}$ & 86 & 50 & 21 \\
\hline 25 & 1.85 & $\mathrm{PhMe} / \mathrm{THF}(3.0: 0.3)$ & Lil & 91 & 60 & 18 \\
\hline 26 & 1.85 & $\mathrm{PhMe} / \mathrm{THF}(3.0: 0.3)$ & $\mathrm{NaOAc}$ & 98 & 39 & 21 \\
\hline 27 & 1.85 & $\mathrm{PhMe} / \mathrm{THF}(3.0: 0.3)$ & $\mathrm{Mgl}_{2}$ & 86 & 62 & 16 \\
\hline 28 & 1.85 & $\mathrm{PhMe} / \mathrm{THF}(3.0: 0.3)$ & none & 100 & 83 & 21 \\
\hline 29 & 1.85 & $\mathrm{PhMe} / \mathrm{THF}(1.2: 0.3)$ & none & 100 & 77 & 28 \\
\hline 30 & 1.85 & $\mathrm{PhMe} / \mathrm{THF}(2.1: 0.3)$ & none & 100 & 78 & 21 \\
\hline 31 & 1.85 & $\mathrm{PhMe} / \mathrm{THF}(4.5: 0.3)$ & none & 95 & 71 & 21 \\
\hline 32 & 1.85 & $\mathrm{PhMe} / \mathrm{THF}(6.0: 0.3)$ & none & 94 & 70 & 19 \\
\hline
\end{tabular}

aDetermined by GC-MS using dodecane as internal standard.

${ }^{b} \mathrm{~A}$ solvent-switch (THF to $\mathrm{PhMe}$ ) of the a-anion solution was performed. 
Table S6. Evaluation of Ni sources

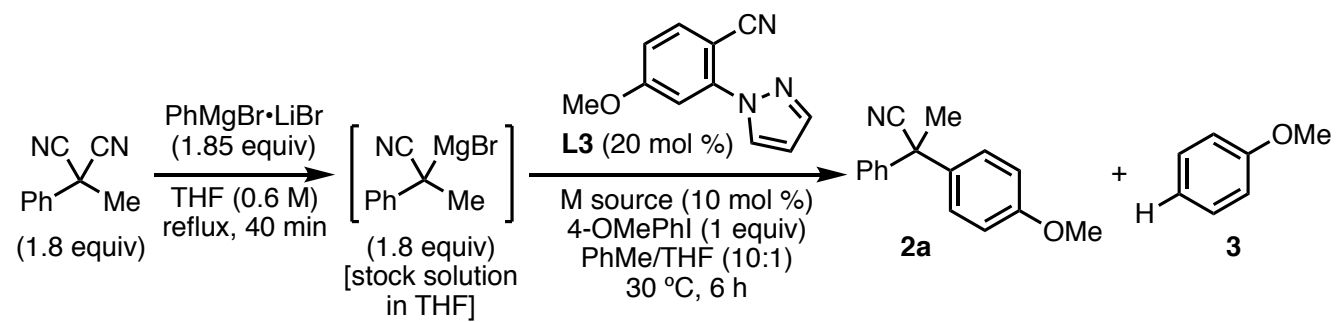

\begin{tabular}{ccccc}
\hline Entry & $\mathrm{M} \mathrm{source}$ & Conv. Ar-I (\%) & Yield 2a $(\%)^{a}$ & ${\text { Yield } \mathbf{3}(\%)^{a}}^{a}$ \\
\hline 1 & $\mathrm{NiCl}_{2}(\mathrm{dme})$ & 100 & 83 & 21 \\
2 & $\mathrm{NiBr}_{2}(\mathrm{dme})$ & 51 & 40 & 16 \\
3 & $\mathrm{Ni}(\mathrm{acac})_{2}$ & 55 & 31 & 16 \\
4 & $\mathrm{Ni}(\mathrm{cod})_{2}$ & 60 & 32 & 21 \\
5 & $\mathrm{Ni}(\mathrm{OAc})_{2}$ & 0 & 0 & 0 \\
6 & $\mathrm{Nil}_{2}$ & 0 & 0 & 0 \\
7 & $\mathrm{NiCl}_{2}(\mathrm{PhCN})_{4}$ & 1 & 1 & 5 \\
8 & $\mathrm{NiCl}_{2}(\mathrm{tmeda})$ & 55 & 19 & 29 \\
9 & $\mathrm{NiCl}_{2}$ & 0 & 0 & 0 \\
10 & $\mathrm{NiCl}_{2} \cdot 6 \mathrm{H}_{2} \mathrm{O}$ & 14 & 3 & 7 \\
11 & $\mathrm{none}_{1}$ & 0 & 0 & 0 \\
12 & $\mathrm{Pd}(\mathrm{OAc})_{2}{ }^{b}$ & 100 & 10 & 49 \\
\hline
\end{tabular}

aDetermined by GC-MS using dodecane as internal standard.

${ }^{b}$ CyJohnPhos (10 mol \%) was used instead of L3. 


\section{Preparation of benzonitrile ligands}

Safety note: All reactions involving metal cyanide salts were performed in a well ventilated fumehood and care was taken to ensure reaction and workup solutions were kept basic. All respective glassware was double-rinsed in the fumehood after use and all cyanide-containing solutions were disposed of appropriately.

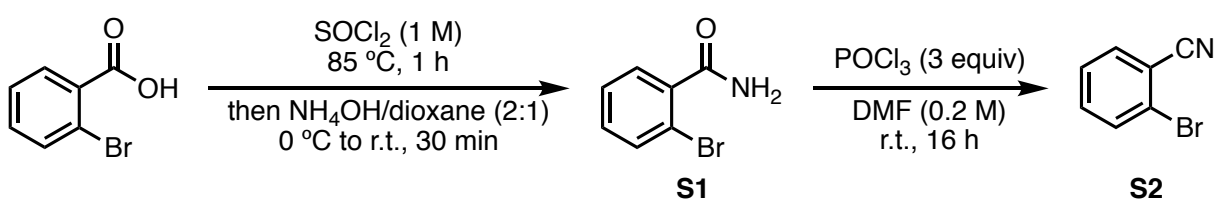

2-Bromobenzamide (S1): To a 250-mL flask was added 2-bromobenzoic acid (12 g, $60 \mathrm{mmol}$, 1.0 equiv) and thionyl chloride ( $60 \mathrm{~mL}, 823 \mathrm{mmol}, 14$ equiv). The flask was equipped with a reflux condenser and the reaction was heated at reflux at $85^{\circ} \mathrm{C}$ until the solution turned clear (ca. $10 \mathrm{~min}$ ), then for an additional $1 \mathrm{~h}$ at the same temperature. The reaction was cooled to r.t. and concentrated. To the concentrate was added $\mathrm{PhH}(100 \mathrm{~mL})$ and the solution was concentrated again. The concentrate was dissolved in 1,4-dioxane (reagent grade; $100 \mathrm{~mL}$ ) and was transferred to a 1-L Erlenmeyer flask. The solution was cooled to $0{ }^{\circ} \mathrm{C}$ and $\mathrm{NH}_{4} \mathrm{OH}(200 \mathrm{~mL})$ was added at once. The reaction was stirred at r.t. for $30 \mathrm{~min}$. The solution was extracted with $\operatorname{DCM}(\times 3)$ and the organic extracts were combined, washed with brine $(\times 1)$, dried over $\mathrm{MgSO}_{4}$, and concentrated to yield the product as a white solid which was used in the next step without further purification.

2-Bromobenzonitrile (S2): To a 500-mL flask were added 2-bromobenzamide (crude material from previous step, ca. $60 \mathrm{mmol}, 1$ equiv) and DMF (reagent grade; $300 \mathrm{~mL}, 0.20 \mathrm{M}$ ). $\mathrm{POCl}_{3}(17$ $\mathrm{mL}, 180 \mathrm{mmol}, 3.0$ equiv) was added at r.t. and the reaction was stirred at r.t. for $16 \mathrm{~h}$. The solution was poured into a 2-L Erlenmeyer flask and was diluted with $\mathrm{H}_{2} \mathrm{O}(500 \mathrm{~mL})$. The solution was cooled to $0{ }^{\circ} \mathrm{C}$ and was neutralized with solid $\mathrm{NaHCO}_{3}$ to bring the solution to $\mathrm{pH}$ 8. The solution was extracted with $\mathrm{Et}_{2} \mathrm{O}(\times 3)$ and the organic fractions were combined, washed with brine, dried over $\mathrm{MgSO}_{4}$, and concentrated to yield the product as a white solid (8.1 g, 45 mmol, $75 \%$ over 2 steps). ${ }^{1} \mathbf{H}$ NMR $\left(400 \mathrm{MHz}, \mathrm{CDCl}_{3}, 298 \mathrm{~K}\right): \delta_{\mathrm{H}} 7.79-7.65(\mathrm{~m}, 2 \mathrm{H}), 7.55-7.40$ (m, 2H) ppm; ${ }^{13} \mathbf{C}\left\{{ }^{1} \mathbf{H}\right\}$ NMR (100 MHz, $\left.\mathrm{CDCl}_{3}, 298 \mathrm{~K}\right): \delta_{\mathrm{C}} 134.3,133.9,133.2,127.6,125.4$, 117.1, $116.0 \mathrm{ppm} ; \mathbf{R}_{\mathbf{f}}(9: 1$ hexanes/EtOAc; UV): 0.46 .

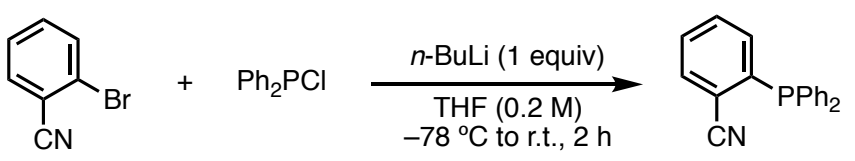

(1 equiv) (1 equiv)

2-(Diphenylphosphaneyl)benzonitrile (L1): ${ }^{6}$ To a flame-dried 100-mL flask was added THF $(25 \mathrm{~mL}, 0.20 \mathrm{M})$. The solution was sparged with Ar for $15 \mathrm{~min}$ and 2-bromobenzonitrile $(0.91 \mathrm{~g}$, $5.0 \mathrm{mmol}, 1.0$ equiv) was added. The solution was cooled to $-78{ }^{\circ} \mathrm{C}$ and $n$-BuLi $(3.4 \mathrm{~mL}$ of a $1.46 \mathrm{M}$ solution in hexanes, $5.0 \mathrm{mmol}, 1.0$ equiv) was added dropwise. The solution was stirred at $-78^{\circ} \mathrm{C}$ for $1 \mathrm{~h}$. To a separate flame-dried 25 -mL flask was added THF $(5.0 \mathrm{~mL})$. The solution was sparged with Ar for $15 \mathrm{~min}$, and chlorodiphenylphosphine $(0.92 \mathrm{~mL}, 5.0 \mathrm{mmol}, 1.0$ equiv) was added. The solution of chlorodiphenylphosphine in THF was transferred to the solution of lithiated $\mathbf{S 2}$ dropwise using a syringe. The reaction was stirred for $1 \mathrm{~h}$ at $-78^{\circ} \mathrm{C}$ and then at r.t. 
for $30 \mathrm{~min}$. The reaction was opened to air, diluted with $\mathrm{Et}_{2} \mathrm{O}$, washed with $\mathrm{H}_{2} \mathrm{O}(\times 1)$ and brine $(\times 1)$, dried over $\mathrm{MgSO}_{4}$, and concentrated. The crude residue was purified by flash column chromatography (gradient of 5-10\% EtOAc/hexanes) to yield the product as a white solid $(0.34$ g, $1.2 \mathrm{mmol}, 24 \%)$. Analytical data: ${ }^{6} \mathbf{1} \mathbf{H}$ NMR (400 MHz, $\left.\mathrm{CDCl}_{3}, 298 \mathrm{~K}\right): \delta_{\mathrm{H}} 7.75-7.67(\mathrm{~m}, 1 \mathrm{H})$, 7.54-7.23 (m, 12H), 7.09-7.01 (m, 1H) ppm; ${ }^{31}$ P NMR (162 MHz, $\left.\mathrm{CDCl}_{3}, 298 \mathrm{~K}\right): \delta_{\mathrm{P}}-8.43$; ${ }^{13} \mathbf{C}\left\{{ }^{1} \mathbf{H}\right\}$ NMR $\left(100 \mathrm{MHz}, \mathrm{CDCl}_{3}, 298 \mathrm{~K}\right): \delta_{\mathrm{C}} 143.1(\mathrm{~d}, J=19.7 \mathrm{~Hz}), 134.7(\mathrm{~d}, J=10.2 \mathrm{~Hz})$, $134.1(\mathrm{~d}, J=20.3 \mathrm{~Hz}), 133.8(\mathrm{~d}, J=4.7 \mathrm{~Hz}), 133.4,132.4,129.4,128.86,128.85$ (d, $J=7.3 \mathrm{~Hz})$, $118.0(\mathrm{~d}, J=32.6 \mathrm{~Hz}), 117.6(\mathrm{~d}, J=3.7 \mathrm{~Hz}) \mathrm{ppm} ; \mathbf{R}_{\mathbf{f}}(9: 1$ hexanes/EtOAc; UV/p-anisaldehyde): 0.36 .

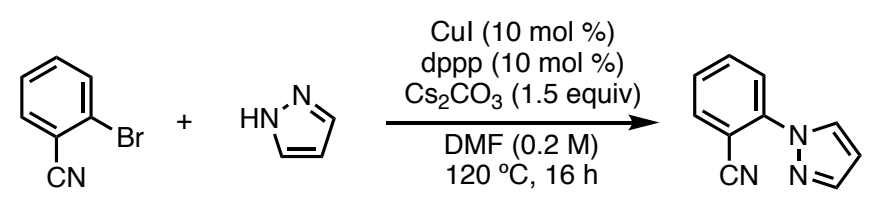

(1 equiv) (1.2 equiv)

2-(1H-Pyrazol-1-yl)benzonitrile) (L2): To a flame-dried 100-mL round-bottom flask was added 2-bromobenzonitrile $(0.91 \mathrm{~g}, 5.0 \mathrm{mmol}, 1.0$ equiv), pyrazole $(0.41 \mathrm{~g}, 6.0 \mathrm{mmol}, 1.2 \mathrm{equiv})$, copper(I) iodide (95 mg, $0.50 \mathrm{mmol}, 10 \mathrm{~mol} \%$ ), dppp (0.21 g, $0.50 \mathrm{mmol}, 10 \mathrm{~mol} \%$ ), cesium carbonate $(2.4 \mathrm{~g}, 7.5 \mathrm{mmol}, 1.5$ equiv), and DMF $(25 \mathrm{~mL}, 0.20 \mathrm{M})$. The reaction was sealed with a septum and electrical tape and was stirred at $120{ }^{\circ} \mathrm{C}$ for $16 \mathrm{~h}$. The reaction was cooled to r.t., quenched with sat. aq. $\mathrm{NH}_{4} \mathrm{Cl}$, and extracted with EtOAc $(\times 3)$. The organic fractions were combined, washed with $\mathrm{NaCl}(\times 1)$, dried over $\mathrm{MgSO}_{4}$, and concentrated. The crude residue was purified by flash column chromatography (gradient of 20-40\% EtOAc/hexanes) to yield the product as an orange oil $(0.61 \mathrm{~g}, 3.6 \mathrm{mmol}, 72 \%)$. Analytical data: ${ }^{1}{ }^{1} \mathbf{H} ~ \mathbf{~ M R}\left(400 \mathrm{MHz}, \mathrm{CDCl}_{3}\right.$, $298 \mathrm{~K}): \delta_{\mathrm{H}} 8.19-8.11(\mathrm{~m}, 1 \mathrm{H}), 7.88-7.66(\mathrm{~m}, 4 \mathrm{H}), 7.48-7.39(\mathrm{~m}, 1 \mathrm{H}), 6.60-6.51(\mathrm{~m}, 1 \mathrm{H}) \mathrm{ppm}$; ${ }^{13} \mathbf{C}\left\{{ }^{1} \mathbf{H}\right\}$ NMR $\left(100 \mathrm{MHz}, \mathrm{CDCl}_{3}, 298 \mathrm{~K}\right): \delta_{\mathrm{C}} 142.3,142.0,134.4,134.0,129.5,127.2,124.3$, 117.0, 108.5, 105.3 ppm; $\mathbf{R}_{\mathbf{f}}\left(9: 1\right.$ hexanes/EtOAc; $\left.\mathrm{UV} / \mathrm{KMnO}_{4}\right): 0.22$.

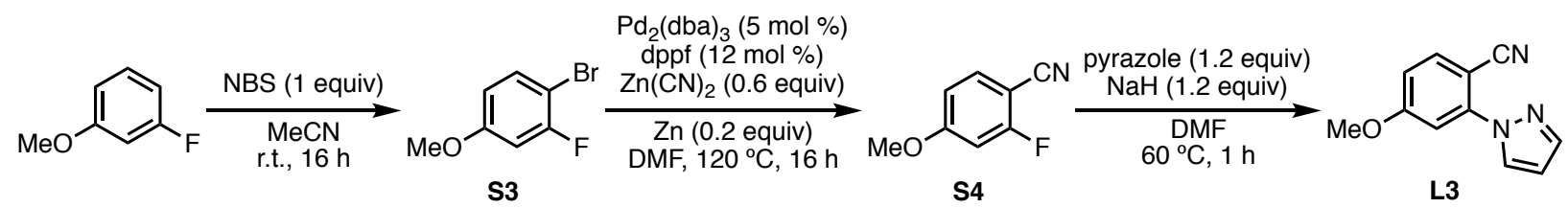

1-Bromo-2-fluoro-4-methoxybenzene (S3): ${ }^{8}$ To a $250-\mathrm{mL}$ flask with a stir bar were sequentially added $\mathrm{MeCN}(100 \mathrm{~mL}, 0.40 \mathrm{M})$, 3-fluoroanisole (4.9 mL, $40 \mathrm{mmol}, 1.0$ equiv), and $N$-bromosuccinimide ( $7.1 \mathrm{~g}, 40 \mathrm{mmol}, 1.0$ equiv), and the reaction was stirred at r.t. for $16 \mathrm{~h}$. The reaction was quenched with $\mathrm{H}_{2} \mathrm{O}$ and extracted with EtOAc $(\times 3)$, and the organic fractions were combined, washed with $\mathrm{H}_{2} \mathrm{O}(\times 1)$ and brine $(\times 1)$, dried over $\mathrm{MgSO}_{4}$, and concentrated to yield the product as a colourless oil $(7.87 \mathrm{~g}, 38.4 \mathrm{mmol}, 96 \%)$. Analytical data: ${ }^{9} \mathbf{H}$ NMR $(500 \mathrm{MHz}$, $\mathrm{CDCl}_{3}, 298 \mathrm{~K}$ ): $\delta_{\mathrm{H}} 7.40(\mathrm{dd}, J=8.9,8.1 \mathrm{~Hz}, 1 \mathrm{H}), 6.69$ (dd, $\left.J=10.5,2.9 \mathrm{~Hz}, 1 \mathrm{H}\right), 6.61$ (ddd, $J=$ 8.9, 2.9, $1.1 \mathrm{~Hz}, 1 \mathrm{H}), 3.78$ (s, 3H) ppm; ${ }^{19} \mathbf{F}\left\{{ }^{1} \mathbf{H}\right\}$ NMR $\left(376 \mathrm{MHz}, \mathrm{CDCl}_{3}, 298 \mathrm{~K}\right): \delta_{\mathrm{F}}-105.3$ ppm; ${ }^{13} \mathbf{C}\left\{{ }^{1} \mathbf{H}\right\}$ NMR $\left(125 \mathrm{MHz}, \mathrm{CDCl}_{3}, 298 \mathrm{~K}\right): \delta_{\mathrm{C}} 160.5(\mathrm{~d}, J=28.0 \mathrm{~Hz}), 207.3(\mathrm{~d}, J=206.3$ $\mathrm{Hz}), 133.4$ (d, $J=2.2 \mathrm{~Hz}), 111.5$ (d, $J=3.2 \mathrm{~Hz}), 103.0$ (d, $J=25.6 \mathrm{~Hz}), 99.4$ (d, $J=21.3 \mathrm{~Hz})$, $55.9 \mathrm{ppm}$.

2-Fluoro-4-methoxybenzonitrile (S4): Caution: Proper care was taken with cyanide handling (see safety note on page S10). To a flame-dried 100-mL flask with a stir bar were added zinc(II) 
cyanide ( $0.70 \mathrm{~g}, 6.0 \mathrm{mmol}, 0.60$ equiv), $\mathrm{Pd}_{2}(\mathrm{dba})_{3}(0.46 \mathrm{~g}, 0.50 \mathrm{mmol}, 0.050$ equiv), dppf ( 0.55 $\mathrm{g}, 1.0 \mathrm{mmol}, 0.10$ equiv), and activated $\mathrm{Zn}(0)$ dust $(0.13 \mathrm{~g}, 2.0 \mathrm{mmol}, 0.20$ equiv). The flask was evacuated and backfilled with $\mathrm{N}_{2}(\times 3)$ and DMF $(30 \mathrm{~mL}, 0.33 \mathrm{M})$ was added, followed by 1 bromo-2-fluoro-4-methoxybenzene $(1.3 \mathrm{~mL}, 10 \mathrm{mmol}, 1.0$ equiv). The reaction was stirred at $120^{\circ} \mathrm{C}$ for $16 \mathrm{~h}$. The reaction was cooled to r.t. and quenched with $\mathrm{H}_{2} \mathrm{O}$. The solution was extracted with EtOAc $(\times 3)$, and the organic fractions were combined, washed with $\mathrm{H}_{2} \mathrm{O}(\times 1)$ and brine $(\times 1)$, dried over $\mathrm{MgSO}_{4}$, and concentrated. The crude residue was purified by flash column chromatography (gradient of 10-30\% EtOAc/hexanes) to yield the product as an off-white solid (1.3 g, 8.6 mmol, 86\%). Analytical data: ${ }^{10}{ }^{1} \mathbf{H}$ NMR (400 MHz, $\left.\mathrm{CDCl}_{3}, 298 \mathrm{~K}\right): \delta_{\mathrm{H}} 7.52$ (dd, $J=$ 8.7, $7.4 \mathrm{~Hz}, 1 \mathrm{H}$ ), 6.77 (ddd, $J=8.7,2.4,0.7 \mathrm{~Hz}, 1 \mathrm{H}), 6.71$ (dd, $J=10.9,2.4 \mathrm{~Hz}, 1 \mathrm{H}), 3.86$ (s, $3 \mathrm{H}) \mathrm{ppm} ;{ }^{19} \mathbf{F}\left\{{ }^{1} \mathbf{H}\right\} \mathbf{N M R}\left(376 \mathrm{MHz}, \mathrm{CDCl}_{3}, 298 \mathrm{~K}\right): \delta_{\mathrm{F}}-104.1 \mathrm{ppm}$.

4-Methoxy-2-(1H-pyrazol-1-yl)benzonitrile (L3): To a flame-dried 100-mL flask with a stir bar was added pyrazole $(0.70 \mathrm{~g}, 10.3 \mathrm{mmol}, 1.2$ equiv $)$, and the flask was evacuated and backfilled with $\mathrm{N}_{2}(\times 3)$. DMF $(30 \mathrm{~mL}, 0.29 \mathrm{M})$ was added. The reaction was cooled to $0{ }^{\circ} \mathrm{C}$, briefly opened to air, and sodium hydride $(0.41 \mathrm{~g}$ of a $60 \% \mathrm{w} / \mathrm{w}$ dispersion in mineral oil, 10.3 mmol, 1.2 equiv) was added. The reaction was stirred at r.t. for $15 \mathrm{~min}$, then 2-fluoro-4methoxybenzonitrile ( $1.3 \mathrm{~g}, 8.6 \mathrm{mmol}, 1.0$ equiv) was added, and the reaction was stirred at 60 ${ }^{\circ} \mathrm{C}$ for $1 \mathrm{~h}$. The reaction was cooled to r.t. and quenched with sat. aq. $\mathrm{NaHCO}_{3}$. The solution was extracted with EtOAc $(\times 3)$, and the organic fractions were combined, washed with $\mathrm{H}_{2} \mathrm{O}(\times 1)$ and brine $(\times 1)$, dried over $\mathrm{MgSO}_{4}$, and concentrated. The crude residue was purified by flash column chromatography (gradient of 10-40\% EtOAc/hexanes) to yield the product as an off-white solid (1.2 g, 6.0 mmol, 70\%). Analytical data: ${ }^{11} \mathbf{H}$ NMR (400 MHz, $\left.\mathrm{CDCl}_{3}, 298 \mathrm{~K}\right): \delta_{\mathrm{H}} 8.21$ (dd, $J=$ 2.7, $0.8 \mathrm{~Hz}, 1 \mathrm{H}), 7.79(\mathrm{~d}, J=1.8 \mathrm{~Hz}, 1 \mathrm{H}), 7.66(\mathrm{dd}, J=8.7,0.8 \mathrm{~Hz}, 1 \mathrm{H}), 7.34(\mathrm{dd}, J=2.7,1.1$ $\mathrm{Hz}, 1 \mathrm{H}), 6.92$ (ddd, $J=8.7,2.5,0.7 \mathrm{~Hz}, 1 \mathrm{H}), 6.54$ (ddd, $J=2.6,1.8,0.7 \mathrm{~Hz}, 1 \mathrm{H}), 3.92$ (s, 3H) ppm; ${ }^{13} \mathbf{C}\left\{{ }^{1} \mathbf{H}\right\} \mathbf{N M R}\left(100 \mathrm{MHz}, \mathrm{CDCl}_{3}, 298 \mathrm{~K}\right): \delta_{\mathrm{C}} 163.9,144.0,142.3,135.8,129.8,117.7$, 114.2, 109.3, 108.6, 96.6, 56.1 ppm; $\mathbf{R}_{\mathbf{f}}(7: 3$ hexanes/EtOAc; UV/KMnO 4$): 0.30$.
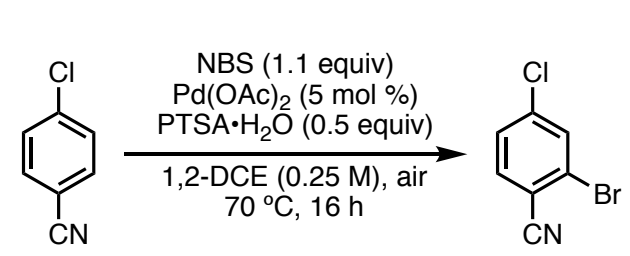

S5

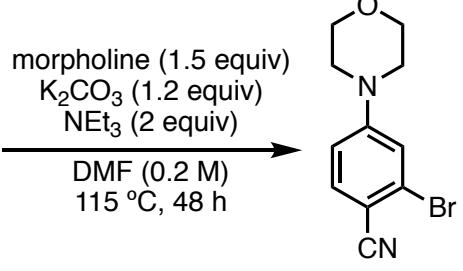

S6
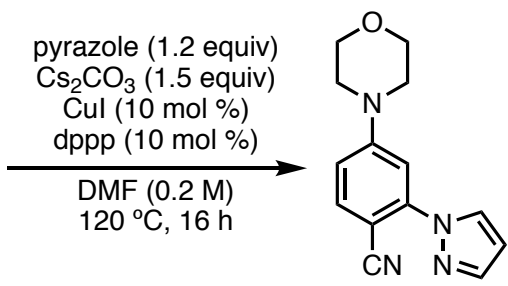

L4

2-Bromo-4-chlorobenzonitrile (S5): ${ }^{12}$ To a 50 -mL flame-dried flask with stir bar were added 4chlorobenzonitrile ( $0.69 \mathrm{~g}, 5.0 \mathrm{mmol}, 1.0$ equiv), $N$-bromosuccinimide $(0.89 \mathrm{~g}, 5.0 \mathrm{mmol}, 1.0$ equiv), palladium(II) acetate (56 mg, $0.25 \mathrm{mmol}, 5.0 \mathrm{~mol} \%$ ), $p$-toluenesulfonic acid monohydrate ( $0.48 \mathrm{~g}, 2.5 \mathrm{mmol}, 0.50$ equiv), and 1,2-dichloroethane ( $20 \mathrm{~mL}, 0.25 \mathrm{M})$. The reaction was sealed and stirred at $70^{\circ} \mathrm{C}$ for $16 \mathrm{~h}$ under an atmosphere of air. The reaction was cooled to r.t., quenched with sat. aq. $\mathrm{NH}_{4} \mathrm{Cl}$, and extracted with $\mathrm{DCM}(\times 3)$. The organic fractions were combined, washed with brine $(\times 1)$, dried over $\mathrm{MgSO}_{4}$, and concentrated. The crude residue was purified by flash column chromatography (gradient of $0-5 \%$ EtOAc/hexanes) to yield the product as a white solid $(0.37 \mathrm{~g}, 1.7 \mathrm{mmol}, 34 \%)$. Analytical data: ${ }^{13}{ }^{1} \mathbf{H ~} \mathbf{N M R}\left(400 \mathrm{MHz}, \mathrm{CDCl}_{3}\right.$, $298 \mathrm{~K}): \delta_{\mathrm{H}} 7.75-7.69(\mathrm{~m}, 1 \mathrm{H}), 7.63-7.57(\mathrm{~m}, 1 \mathrm{H}), 7.45-7.39(\mathrm{~m}, 1 \mathrm{H}) \mathrm{ppm} ;{ }^{13} \mathbf{C}\left\{{ }^{1} \mathbf{H}\right\} \mathbf{N M R}(100$ $\left.\mathrm{MHz}, \mathrm{CDCl}_{3}, 298 \mathrm{~K}\right): \delta_{\mathrm{C}} 140.0,134.9,133.3,128.3,126.0,116.4,114.4$ ppm; $\mathbf{R}_{\mathbf{f}}(9: 1$ hexanes/EtOAc; UV): 0.60. 
2-Bromo-4-morpholinobenzonitrile (S6): To a flame-dried 25-mL round-bottom flask with stir bar were added 2-bromo-4-chlorobenzonitrile ( $0.22 \mathrm{~g}, 1.0 \mathrm{mmol}, 1.0$ equiv) and potassium carbonate $\left(0.17 \mathrm{~g}, 1.2 \mathrm{mmol}, 1.2\right.$ equiv). The flask was sealed, evacuated and backfilled with $\mathrm{N}_{2}$ $(\times 3)$, and DMF $(5.0 \mathrm{~mL}, 0.20 \mathrm{M})$ was added, followed by triethylamine $(0.28 \mathrm{~mL}, 2.0 \mathrm{mmol}, 2.0$ equiv) and morpholine $\left(0.13 \mathrm{~mL}, 1.5 \mathrm{mmol}, 1.5\right.$ equiv). The reaction was stirred at $115^{\circ} \mathrm{C}$ for 48 h. The reaction was cooled to r.t., quenched with sat. aq. $\mathrm{NH}_{4} \mathrm{Cl}$, and extracted with EtOAc $(\times 3)$. The organic fractions were combined, dried over $\mathrm{MgSO}_{4}$, and concentrated. The crude residue was purified by flask column chromatography (gradient of 5-20\% EtOAc/hexanes) to yield the product as an off-white solid (45 $\mathrm{mg}, 0.17 \mathrm{mmol}, 17 \%$ ). The analytical data was consistent with literature. ${ }^{14}$

4-Morpholino-2-(1H-pyrazol-1-yl)benzonitrile (L4): To a flame-dried 16-mL culture tube were added 2-bromo-4-morpholinobenzonitrile (45 mg, $0.17 \mathrm{mmol}, 1.0$ equiv), pyrazole (14 $\mathrm{mg}$, $0.20 \mathrm{mmol}, 1.2$ equiv), copper(I) iodide (3.2 mg, $0.017 \mathrm{mmol}, 10 \mathrm{~mol} \%$ ), dppp (4.9 mg, 0.017 $\mathrm{mmol}, 10 \mathrm{~mol} \%)$, and cesium carbonate $(85 \mathrm{mg}, 0.26 \mathrm{mmol}, 1.5$ equiv). The reaction was stirred at $120^{\circ} \mathrm{C}$ for $16 \mathrm{~h}$ and was cooled to r.t. The reaction was quenched with sat. aq. $\mathrm{NH}_{4} \mathrm{Cl}$, extracted with EtOAc $(\times 2)$, and the organic fractions were combined, dried over $\mathrm{MgSO}_{4}$, and concentrated. The crude residue was purified by flash column chromatography (gradient of 20$30 \% \mathrm{EtOAc} / \mathrm{h}$ exanes) to yield the product as an off-white solid $(27 \mathrm{mg}, 0.11 \mathrm{mmol}, 65 \%)$. Analytical data: ${ }^{1} \mathbf{H}$ NMR $\left(400 \mathrm{MHz}, \mathrm{CDCl}_{3}, 298 \mathrm{~K}\right)$ : $\delta_{\mathrm{H}} 7.99-7.94(\mathrm{~m}, 1 \mathrm{H}), 7.78-7.74(\mathrm{~m}, 1 \mathrm{H})$, 7.67-7.61 (m, 1H), 7.51-7.47 (m, 1H), 7.30-7.23 (m, 2H), 3.97-3.88 (m, 4H), 3.36-3.26 (m, 4H) ppm; ${ }^{13} \mathbf{C}\left\{{ }^{1} \mathbf{H}\right\} \mathbf{N M R}\left(100 \mathrm{MHz}, \mathrm{CDCl}_{3}, 298 \mathrm{~K}\right): \delta_{\mathrm{C}} 156.9,144.0,142.2,135.7,127.0,118.1$, 111.4, 109.0, 108.9, 102.8, 66.8, $51.7 \mathrm{ppm}$; HRMS $m / z(\mathrm{M}+\mathrm{H})$ : calcd for $\mathrm{C}_{14} \mathrm{H}_{15} \mathrm{~N}_{4} \mathrm{O}(\mathrm{M}+\mathrm{H})$ : 255.1240; found: 255.1237 ; m.p.: $107-108^{\circ} \mathrm{C}$; $\mathbf{R}_{\mathbf{f}}(8: 2$ hexanes/EtOAc; UV): 0.22.

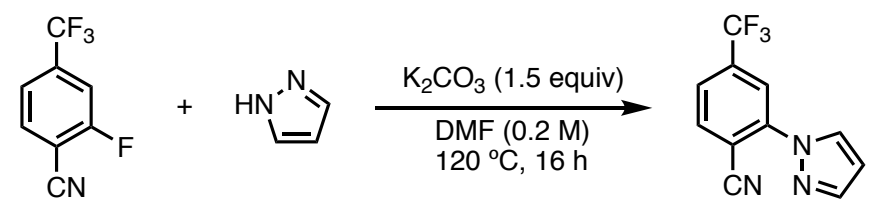

(1 equiv) (1.2 equiv)

2-(1H-Pyrazol-1-yl)-4-(trifluoromethyl)benzonitrile (L5): To a flame-dried 25-mL flask with stir bar were added pyrazole ( $82 \mathrm{mg}, 1.2 \mathrm{mmol}, 1.2$ equiv) and potassium carbonate $(0.21 \mathrm{~g}, 1.5$ mmol, 1.5 equiv). The flask was sealed and then evacuated and backfilled with $\mathrm{N}_{2}(\times 3)$. DMF $(5.0 \mathrm{~mL}, 0.20 \mathrm{M})$ was added, followed by 2-fluoro-4-(trifluoromethyl)benzonitrile $(0.14 \mathrm{~mL}, 1.0$ mmol, 1.0 equiv). The reaction was stirred at $120^{\circ} \mathrm{C}$ for $16 \mathrm{~h}$. The reaction was cooled to r.t., opened to air, quenched with sat. aq. $\mathrm{NH}_{4} \mathrm{Cl}$, and extracted with EtOAc $(\times 3)$. The organic fractions were combined, dried over $\mathrm{MgSO}_{4}$, and concentrated. The crude residue was purified by flash column chromatography (gradient of 5-15\% EtOAc/hexanes) to yield the product as a white solid (0.22 g, $0.93 \mathrm{mmol}, 93 \%) .{ }^{1} \mathbf{H}$ NMR (400 MHz, $\left.\mathrm{CDCl}_{3}, 298 \mathrm{~K}\right): \delta_{\mathrm{H}} 8.29-8.23$ (m, $1 \mathrm{H}), 8.17-8.12(\mathrm{~m}, 1 \mathrm{H}), 7.95-7.89(\mathrm{~m}, 1 \mathrm{H}), 7.89-7.81(\mathrm{~m}, 1 \mathrm{H}), 7.70-7.63(\mathrm{~m}, 1 \mathrm{H}), 6.64-6.56$ (m, 1H) ppm; ${ }^{19} \mathbf{F}\left\{{ }^{1} \mathbf{H}\right\}$ NMR $\left(376 \mathrm{MHz}, \mathrm{CDCl}_{3}, 298 \mathrm{~K}\right): \delta_{\mathrm{F}}-63.6 \mathrm{ppm} ;{ }^{13} \mathbf{C}\left\{{ }^{1} \mathbf{H}\right\} \mathbf{N M R}(100$ $\left.\mathrm{MHz}, \mathrm{CDCl}_{3}, 298 \mathrm{~K}\right): \delta_{\mathrm{C}} 143.0,142.4,135.9(\mathrm{q}, J=33.8 \mathrm{~Hz}), 135.3,129.5,123.9,123.4(\mathrm{q}, J=$ $3.6 \mathrm{~Hz}), 121.2(\mathrm{q}, J=3.9 \mathrm{~Hz}), 116.0,109.3,107.7 \mathrm{ppm}$; HRMS $m / z$ (DART): calcd for $\mathrm{C}_{11} \mathrm{H}_{7} \mathrm{~N}_{3} \mathrm{~F}_{3}(\mathrm{M}+\mathrm{H}): 238.0587$; found: 238.0596 ; m.p.: $50-51^{\circ} \mathrm{C} ; \mathbf{R}_{\mathbf{f}}(9: 1$ hexanes/EtOAc; UV): 0.43 . 


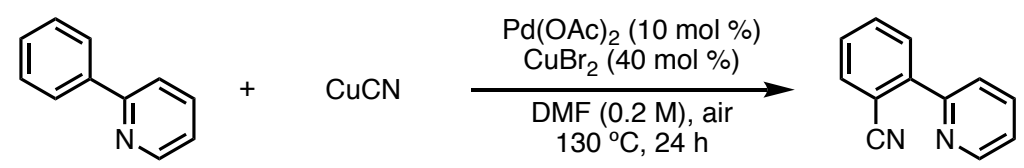

(1 equiv)

(1.2 equiv)

2-(Pyridin-2-yl)benzonitrile (L6): ${ }^{15}$ Caution: Proper care was taken with cyanide handling (see safety note on page S10). To a 100-mL flask were added 2-phenylpyridine (1.4 mL, $10 \mathrm{mmol}$, 1.0 equiv), copper(I) cyanide (1.1 g, $12 \mathrm{mmol}, 1.2$ equiv), palladium(II) acetate $(0.23 \mathrm{~g}, 1.0$ mmol, $10 \mathrm{~mol} \mathrm{\% ),} \mathrm{copper(II)} \mathrm{bromide}(0.89 \mathrm{~g}, 4.0 \mathrm{mmol}, 40 \mathrm{~mol} \%$ ), and DMF (50 mL, $0.20 \mathrm{M})$. The flask was equipped with a reflux condenser and was stirred under air at $130{ }^{\circ} \mathrm{C}$ for $24 \mathrm{~h}$. The solution was quenched with sat. aq. $\mathrm{NaHCO}_{3}$, extracted with EtOAc $(\times 3)$, and the organic fractions were combined, washed with brine $(\times 3)$, dried over $\mathrm{MgSO}_{4}$, and concentrated. The crude residue was purified by flash column chromatography (gradient of 0:0:100 to 30:20:50 EtOAc/DCM/hexanes) to yield the product as a pale yellow solid (0.77 g, $4.3 \mathrm{mmol}, 43 \%)$. Analytical data: ${ }^{15}{ }^{1} \mathbf{H}$ NMR $\left(400 \mathrm{MHz}, \mathrm{CDCl}_{3}, 298 \mathrm{~K}\right): \delta_{\mathrm{H}} 8.79(\mathrm{ddd}, J=4.9,1.8,1.0 \mathrm{~Hz}, 1 \mathrm{H})$, $7.88-7.76(\mathrm{~m}, 4 \mathrm{H}), 7.70(\mathrm{td}, J=7.7,1.4 \mathrm{~Hz}, 1 \mathrm{H}), 7.51$ (td, $J=7.6,1.3 \mathrm{~Hz}, 1 \mathrm{H}), 7.36$ (ddd, $J=$ 7.4, 4.8, $1.3 \mathrm{~Hz}, 1 \mathrm{H}) ;{ }^{13} \mathbf{C}\left\{{ }^{1} \mathbf{H}\right\}$ NMR $\left(100 \mathrm{MHz}, \mathrm{CDCl}_{3}, 298 \mathrm{~K}\right): 155.3,150.0,143.5,136.8$, 134.1, 132.8, 130.0, 128.7, 123.3, 123.2, 118.7, 111.1 ppm; $\mathbf{R}_{\mathbf{f}}$ (5:3:2 hexanes/EtOAc/DCM; UV): 0.32 .

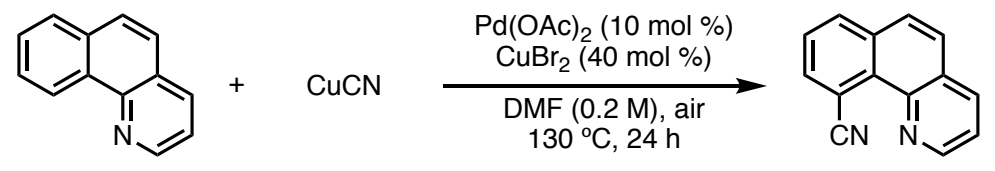

(1 equiv) (1.1 equiv)

Benzo[h]quinoline-10-carbonitrile (L7): ${ }^{15}$ Caution: Proper care was taken with cyanide handling (see safety note on page $\mathrm{S} 10)$. To a $50-\mathrm{mL}$ flask were added benzo[h]quinoline $(0.34 \mathrm{~g}$, $2.0 \mathrm{mmol}, 1.0$ equiv), copper(I) cyanide $(0.18 \mathrm{~g}, 2.2 \mathrm{mmol}, 1.1$ equiv), palladium(II) acetate (45 $\mathrm{mg}, 0.20 \mathrm{mmol}, 10 \mathrm{~mol} \%)$, copper(II) bromide $(0.19 \mathrm{~g}, 0.44 \mathrm{mmol}, 40 \mathrm{~mol} \%)$, and DMF (10 $\mathrm{mL}, 0.20 \mathrm{M})$. The flask was equipped with a reflux condenser and was stirred under air at $130{ }^{\circ} \mathrm{C}$ for $24 \mathrm{~h}$. The solution was quenched with sat. aq. $\mathrm{NaHCO}_{3}$, extracted with EtOAc $(\times 3)$, and the organic fractions were combined, washed with brine $(\times 3)$, dried over $\mathrm{MgSO}_{4}$, and concentrated. The crude residue was purified by flash column chromatography (gradient of 0:0:100 to 30:20:50 EtOAc/DCM/hexanes) to yield the product as an off-yellow solid (0.17 g, $0.84 \mathrm{mmol}, 42 \%)$. Analytical data: ${ }^{15}{ }^{1} \mathbf{H}$ NMR (400 MHz, $\left.\mathrm{CDCl}_{3}, 298 \mathrm{~K}\right): \delta 9.15(\mathrm{dd}, J=4.3,1.8 \mathrm{~Hz}, 1 \mathrm{H}), 8.24(\mathrm{dd}$, $J=8.1,1.8 \mathrm{~Hz}, 1 \mathrm{H}), 8.16(\mathrm{~m}, 2 \mathrm{H}), 7.83(\mathrm{~m}, 2 \mathrm{H}), 7.75(\mathrm{dd}, J=8.1,7.4 \mathrm{~Hz}, 1 \mathrm{H}), 7.64(\mathrm{dd}, J=8.1$, $4.3 \mathrm{~Hz}, 1 \mathrm{H}) ;{ }^{13} \mathbf{C}\left\{{ }^{1} \mathbf{H}\right\}$ NMR $\left(100 \mathrm{MHz}, \mathrm{CDCl}_{3}, 298 \mathrm{~K}\right): \delta_{\mathrm{C}} 148.5,144.6,136.3,135.7,134.1$, $132.7,130.8,127.4,127.4,127.1,127.0,123.1,120.8,109.0$ ppm; $\mathbf{R}_{\mathbf{f}}(7: 2: 1$ hexanes/EtOAc/DCM; UV): 0.29.

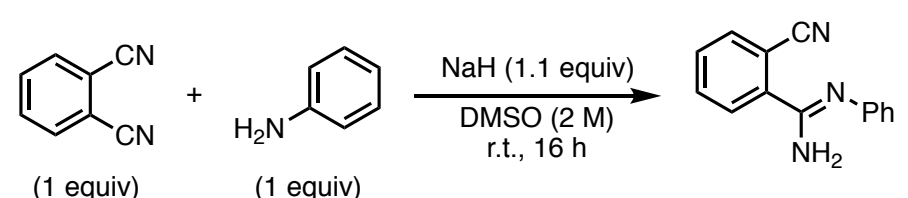

2-Cyano- $N$-phenylbenzimidamide (L8): To a flame-dried $25-\mathrm{mL}$ round-bottom flask with stir bar under $\mathrm{N}_{2}$ were added aniline $(0.91 \mathrm{~mL}, 10 \mathrm{mmol}, 1.0$ equiv) and DMSO (5.0 mL, $2.0 \mathrm{M})$. The flask was briefly opened to air and sodium hydride $(0.44 \mathrm{~g}$ of a $60 \% \mathrm{w} / \mathrm{w}$ dispersion in 
mineral oil, $11 \mathrm{mmol}, 1.1$ equiv) was added at once. The reaction was stirred at r.t. for $30 \mathrm{~min}$ under $\mathrm{N}_{2}$. The reaction was briefly opened to air and phthalonitrile (1.3 g, $10 \mathrm{mmol}, 1.0$ equiv) was added at once. The reaction was stirred at r.t. for $16 \mathrm{~h}$ under $\mathrm{N}_{2}$. The reaction was opened to air and poured into $\mathrm{H}_{2} \mathrm{O}(100 \mathrm{~mL})$, generating a precipitate. The precipitate was collected by filtration using a fritted funnel, was washed with $\mathrm{H}_{2} \mathrm{O}(\times 1)$ and pentane $(\times 1)$, and was dried under high vacuum to yield the product as a brown solid $(1.4 \mathrm{~g}, 6.3 \mathrm{mmol}, 63 \%) .{ }^{\mathbf{1}} \mathbf{H}$ NMR (400 MHz, DMSO- $\delta_{6}, 298 \mathrm{~K}$ ): $\delta_{\mathrm{H}} 8.65$ (br s, $\left.1 \mathrm{H}\right), 8.45$ (br s, $\left.1 \mathrm{H}\right), 7.93-7.77$ (m, 2H), 7.63-7.52 (m, 2H), 7.34-7.17 (m, 4H), 7.03 (dd, $J=7.2,7.2 \mathrm{~Hz}, 1 \mathrm{H}) \mathrm{ppm} ;{ }^{13} \mathbf{C}\left\{{ }^{1} \mathbf{H}\right\}$ NMR (100 MHz, DMSO$\left.\delta_{6}, 298 \mathrm{~K}\right): \delta_{\mathrm{C}} 171.4,164.9,150.3,140.5,135.1,130.8,130.0,128.0,123.6,123.1,121.3,120.6$ ppm; HRMS m/z (DART): calcd for $\mathrm{C}_{14} \mathrm{H}_{12} \mathrm{~N}_{3}$ (DART): 222.1026; found: 222.1026; m.p.: 177$179^{\circ} \mathrm{C}$.

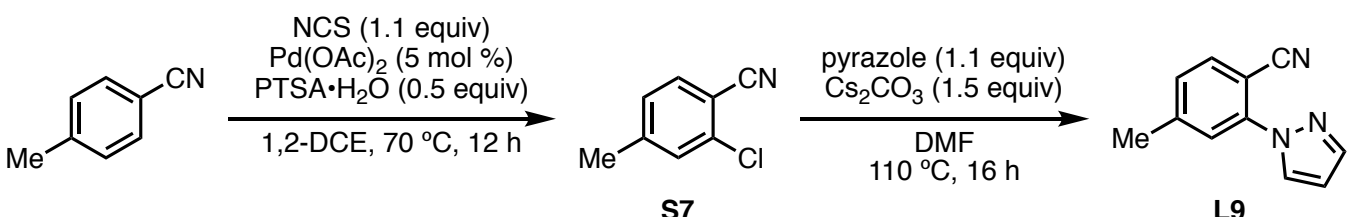

2-Chloro-4-methylbenzonitrile (S7): ${ }^{12}$ To a $100-\mathrm{mL}$ flask with a stir bar were sequentially added $\mathrm{Pd}(\mathrm{OAc})_{2}(90 \mathrm{mg}, 0.40 \mathrm{mmol}, 0.050$ equiv), $N$-chlorosuccinimide (1.2 g, $8.8 \mathrm{mmol}, 1.1$ equiv), PTSA $\bullet \mathrm{H}_{2} \mathrm{O}(0.76 \mathrm{~g}, 4.0 \mathrm{mmol}, 0.50$ equiv), DCE $(32 \mathrm{~mL}, 0.25 \mathrm{M})$, and $p$-tolunitrile $(0.95$ $\mathrm{mL}, 8.0 \mathrm{mmol}, 1.0$ equiv). The reaction was stirred at $70^{\circ} \mathrm{C}$ under air for $12 \mathrm{~h}$. The reaction was cooled to r.t., quenched with $\mathrm{H}_{2} \mathrm{O}$, and extracted with DCM $(\times 3)$, and the organic fractions were combined, washed with brine $(\times 1)$, dried over $\mathrm{MgSO}_{4}$, and concentrated. The crude residue was purified by flash column chromatography (gradient of 0-20\% EtOAc/hexanes) to yield the product as an off-white solid (0.34 g, $2.3 \mathrm{mmol}, 29 \%)$. Analytical data: ${ }^{12}{ }^{1} \mathbf{H}$ NMR (400 MHz, $\left.\mathrm{CDCl}_{3}, 298 \mathrm{~K}\right): \delta_{\mathrm{H}} 7.56-7.51(\mathrm{~m}, 1 \mathrm{H}), 7.34-7.30(\mathrm{~m}, 1 \mathrm{H}), 7.19-7.13(\mathrm{~m}, 1 \mathrm{H}), 2.41(\mathrm{~s}, 3 \mathrm{H}) \mathrm{ppm}$; ${ }^{13} \mathbf{C}\left\{{ }^{1} \mathbf{H}\right\}$ NMR $\left(100 \mathrm{MHz}, \mathrm{CDCl}_{3}, 298 \mathrm{~K}\right): \delta_{\mathrm{C}} 145.5,133.8,132.2,130.7,130.0,128.1,115.4$, $21.8 \mathrm{ppm}$.

4-Methyl-2-(1H-pyrazol-1-yl)benzonitrile (L9): To a 25-mL round-bottom flask with a stir bar were sequentially added 2-chloro-4-methylbenzonitrile $(0.30 \mathrm{~g}, 2.0 \mathrm{mmol}, 1.0$ equiv), pyrazole ( $0.16 \mathrm{~g}, 2.4 \mathrm{mmol}, 1.1$ equiv), cesium carbonate ( $0.98 \mathrm{~g}, 3.0 \mathrm{mmol}, 1.5$ equiv), and DMF (6.0 $\mathrm{mL}, 0.33 \mathrm{M}$ ), and the reaction was stirred at $110^{\circ} \mathrm{C}$ for $16 \mathrm{~h}$. The reaction was cooled to r.t., quenched with $\mathrm{H}_{2} \mathrm{O}$, and extracted with EtOAc $(\times 3)$. The organic fractions were combined, washed with brine $(\times 1)$, dried over $\mathrm{MgSO}_{4}$, and concentrated. The crude residue was purified by flash column chromatography (gradient of 10-50\% EtOAc/hexanes) to yield the product as a white solid (0.12 g, $0.65 \mathrm{mmol}, 33 \%)$. ${ }^{1} \mathbf{H}$ NMR (500 MHz, $\left.\mathrm{CDCl}_{3}, 298 \mathrm{~K}\right): \delta_{\mathrm{H}} 8.14(\mathrm{~d}, J=2.6$ $\mathrm{Hz}, 1 \mathrm{H}), 7.79(\mathrm{~d}, J=1.8 \mathrm{~Hz}, 1 \mathrm{H}), 7.65(\mathrm{~d}, J=8.0 \mathrm{~Hz}, 1 \mathrm{H}), 7.63-7.61(\mathrm{~m}, 1 \mathrm{H}), 7.24-7.21(\mathrm{~m}$, 1H), $6.53(\mathrm{dd}, J=2.6,1.8 \mathrm{~Hz}, 1 \mathrm{H}), 2.48(\mathrm{~s}, 3 \mathrm{H}) \mathrm{ppm} ;{ }^{13} \mathbf{C}\left\{{ }^{1} \mathbf{H}\right\} \mathbf{N M R}\left(125 \mathrm{MHz}, \mathrm{CDCl}_{3}, 298 \mathrm{~K}\right)$ : $\delta_{\mathrm{C}} 145.7,142.2,142.0,134.3,129.7,128.3,125.0,117.4,108.5,102.4,22.0 \mathrm{ppm} ;$ HRMS $\mathrm{m} / \mathrm{z}$ (DART): calcd for $\mathrm{C}_{11} \mathrm{H}_{10} \mathrm{~N}_{3}(\mathrm{M}+\mathrm{H})$ : 184.0869 ; found: 184.0869 ; m.p.: $49-50{ }^{\circ} \mathrm{C}$.

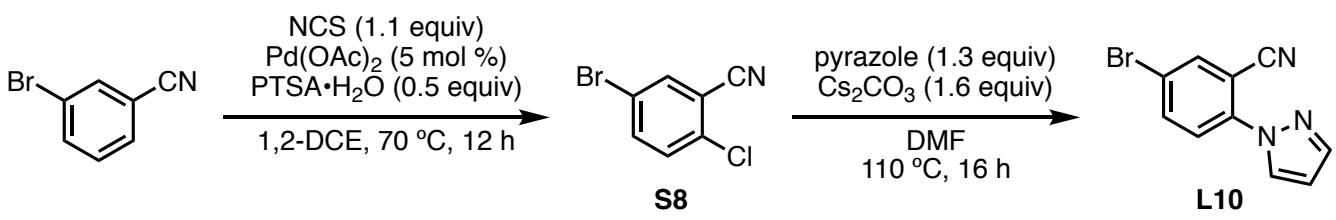


5-Bromo-2-chlorobenzonitrile (S8): ${ }^{12}$ To a 100 -mL flask with a stir bar were added 3bromobenzonitrile (1.5 g, $8.0 \mathrm{mmol}, 1.0$ equiv), $N$-chlorosuccinimide (1.2 g, $8.8 \mathrm{mmol}, 1.1$ equiv), palladium(II) acetate $\left(90 \mathrm{mg}, 0.40 \mathrm{mmol}, 0.050\right.$ equiv), $\mathrm{PTSA} \cdot \mathrm{H}_{2} \mathrm{O}(0.76 \mathrm{~g}, 4.0 \mathrm{mmol}$, 0.50 equiv), and DCE $(32 \mathrm{~mL}, 0.25 \mathrm{M})$. The reaction was stirred at $70{ }^{\circ} \mathrm{C}$ for $12 \mathrm{~h}$ under air. The reaction was cooled to r.t. and quenched with $\mathrm{H}_{2} \mathrm{O}$. The solution was extracted with DCM $(\times 3)$ and the organic extracts were combined, washed with $\mathrm{H}_{2} \mathrm{O}(\times 1)$ and brine $(\times 1)$, dried over $\mathrm{MgSO}_{4}$, and concentrated. The crude residue was purified by flash column chromatography (gradient of 0-20\% EtOAc/hexanes) to yield the product as an off-white solid (0.42 g, $1.9 \mathrm{mmol}$, 24\%). Analytical data: ${ }^{1} \mathbf{H}$ NMR $\left(400 \mathrm{MHz}, \mathrm{CDCl}_{3}, 298 \mathrm{~K}\right): \delta_{\mathrm{H}} 7.79(\mathrm{~d}, J=2.4 \mathrm{~Hz}, 1 \mathrm{H}), 7.66$ $(\mathrm{dd}, J=8.7,2.4 \mathrm{~Hz}, 1 \mathrm{H}), 7.39(\mathrm{~d}, J=8.6 \mathrm{~Hz}, 1 \mathrm{H}) \mathrm{ppm} ;{ }^{13} \mathbf{C}\left\{{ }^{1} \mathbf{H}\right\} \mathbf{N M R}\left(100 \mathrm{MHz}, \mathrm{CDCl}_{3}, 298\right.$ $\mathrm{K}): \delta_{\mathrm{C}} 137.2,136.5,136.1,131.5,120.6,115.2,114.7 \mathrm{ppm}$.

5-Bromo-2-(1H-pyrazol-1-yl)benzonitrile (L10): To a 25-mL flask with a stir bar were added 5-bromo-2-chlorobenzonitrile ( $0.40 \mathrm{~g}, 1.9 \mathrm{mmol}, 1.0$ equiv), pyrazole $(0.16 \mathrm{~g}, 2.4 \mathrm{mmol}, 1.3$ equiv), cesium carbonate $(0.98 \mathrm{~g}, 3.0 \mathrm{mmol}, 1.6 \mathrm{mmol})$, and DMF $(6.0 \mathrm{~mL}, 0.32 \mathrm{M})$, and the reaction was stirred at $110{ }^{\circ} \mathrm{C}$ for $16 \mathrm{~h}$. The reaction was quenched with $\mathrm{H}_{2} \mathrm{O}$ and extracted with EtOAc $(\times 3)$, and the organic extracts were combined, washed with brine $(\times 1)$, dried over $\mathrm{MgSO}_{4}$, and concentrated. The crude residue was purified by flash column chromatography (gradient of 10-50\% EtOAc/hexanes) to yield the product as a white solid $(0.27 \mathrm{~g}, 1.1 \mathrm{mmol}$, 58\%). Analytical data: ${ }^{16}{ }^{1} \mathbf{H}$ NMR $\left(500 \mathrm{MHz}, \mathrm{CDCl}_{3}, 298 \mathrm{~K}\right): \delta_{\mathrm{H}} 8.14(\mathrm{dd}, J=2.7,0.6 \mathrm{~Hz}, 1 \mathrm{H})$, $7.89(\mathrm{~d}, J=2.2 \mathrm{~Hz}, 1 \mathrm{H}), 7.83-7.79(\mathrm{~m}, 2 \mathrm{H}), 7.70(\mathrm{~d}, J=8.8 \mathrm{~Hz}, 1 \mathrm{H}), 6.55(\mathrm{dd}, J=2.6,1.8 \mathrm{~Hz}$, 1H) ppm; ${ }^{13} \mathbf{C}\left\{{ }^{1} \mathbf{H}\right\}$ NMR (125 MHz, $\left.\mathrm{CDCl}_{3}, 298 \mathrm{~K}\right): \delta_{\mathrm{C}} 142.7,141.1,137.3,136.7,129.5,125.7$, 120.2, 115.8, 109.1, 106.6 ppm.

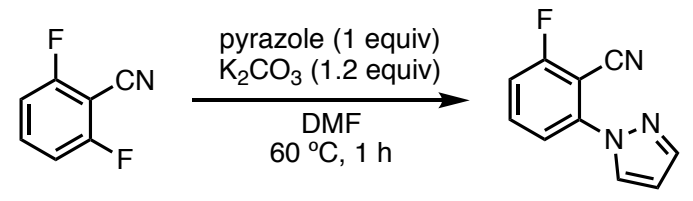

2-Fluoro-6-(1H-pyrazol-1-yl)benzonitrile (L11): To a 50-mL flask with a stir bar were added 2,6-difluorobenzonitrile ( $0.83 \mathrm{~g}, 6.0 \mathrm{mmol}, 1.0$ equiv), pyrazole ( $0.41 \mathrm{~g}, 6.0 \mathrm{mmol}, 1.0$ equiv), potassium carbonate $(0.99 \mathrm{~g}, 7.2 \mathrm{mmol}, 1.2$ equiv), and DMF $(15 \mathrm{~mL}, 0.40 \mathrm{M})$, and the reaction was stirred at $60{ }^{\circ} \mathrm{C}$ for $2 \mathrm{~h}$. The reaction was quenched with $\mathrm{H}_{2} \mathrm{O}$ and extracted with EtOAc $(\times 3)$, and the organic extracts were combined, washed with brine $(\times 1)$, dried over $\mathrm{MgSO}_{4}$, and concentrated. The crude residue was purified by flash column chromatography (gradient of 15$50 \% \mathrm{EtOAc} /$ hexanes $)$ to yield the product as a white solid $(0.93 \mathrm{~g}, 5.0 \mathrm{mmol}, 83 \%) .{ }^{1} \mathbf{H}$ NMR $\left(400 \mathrm{MHz}, \mathrm{CDCl}_{3}, 298 \mathrm{~K}\right): \delta_{\mathrm{H}} 8.17(\mathrm{~d}, J=2.6 \mathrm{~Hz}, 1 \mathrm{H}), 7.82(\mathrm{~d}, J=1.8 \mathrm{~Hz}, 1 \mathrm{H}), 7.71-7.60(\mathrm{~m}$, $2 \mathrm{H}), 7.19(\mathrm{td}, J=8.3,1.1 \mathrm{~Hz}, 1 \mathrm{H}), 6.56(\mathrm{dd}, J=2.6,1.8 \mathrm{~Hz}, 1 \mathrm{H}) \mathrm{ppm} ;{ }^{19} \mathbf{F}\left\{{ }^{1} \mathbf{H}\right\} \mathbf{~ N M R}(376 \mathrm{MHz}$, $\left.\mathrm{CDCl}_{3}, 298 \mathrm{~K}\right): \delta_{\mathrm{F}}-103.5 \mathrm{ppm} ;{ }^{13} \mathbf{C}\left\{{ }^{1} \mathbf{H}\right\} \mathbf{N M R}\left(100 \mathrm{MHz}, \mathrm{CDCl}_{3}, 298 \mathrm{~K}\right): \delta_{\mathrm{C}} 164.40(\mathrm{~d}, J=$ $258.4 \mathrm{~Hz}), 143.1,142.8,135.2$ (d, $J=9.9 \mathrm{~Hz}), 129.6,119.5$ (d, $J=3.5 \mathrm{~Hz}), 114.1$ (d, $J=16.2$ $\mathrm{Hz}), 112.1,109.1,95.4(\mathrm{~d}, J=18.8 \mathrm{~Hz}) \mathrm{ppm}$; HRMS $m / z$ (DART): calcd for $\mathrm{C}_{10} \mathrm{H}_{7} \mathrm{~N}_{3} \mathrm{~F}(\mathrm{M}+\mathrm{H})$ : 188.0619; found: 188.0624 ; m.p.: $62-63^{\circ} \mathrm{C}$. 


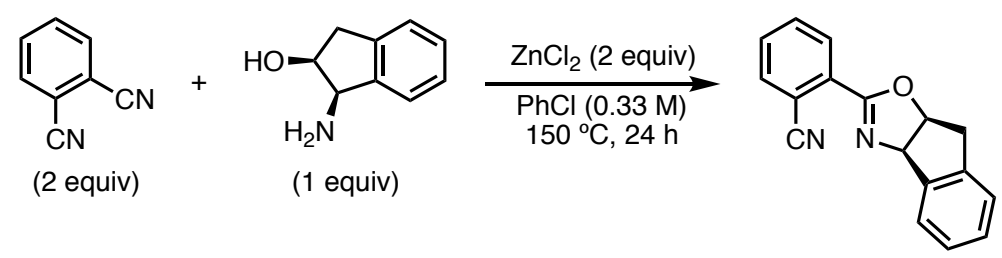

2-((3R,8S)-3,8-Dihydro-8H-indeno[1,2]oxazol-2-yl)benzonitrile (L12): To a flame-dried 50$\mathrm{mL}$ pear-shaped Schlenk flask was added phthalonitrile $(1.3 \mathrm{~g}, 10 \mathrm{mmol}, 2.0$ equiv), and $(1 R, 2 S)$ 1-amino-2,3-dihydro- $1 H$-inden-2-ol ( $0.75 \mathrm{~g}, 5.0 \mathrm{mmol}, 1.0$ equiv). The flask was sealed and brought into a glovebox and $\mathrm{ZnCl}_{2}(1.4 \mathrm{~g}, 10 \mathrm{mmol}, 2.0$ equiv) was added. The flask was sealed, removed from the glovebox, and chlorobenzene $(15 \mathrm{~mL}, 0.33 \mathrm{M})$ was added. The reaction was stirred at $150{ }^{\circ} \mathrm{C}$ for $24 \mathrm{~h}$. The reaction was cooled to r.t., opened to air, quenched with sat. aq. $\mathrm{NH}_{4} \mathrm{Cl}$, and extracted with EtOAc $(\times 3)$. The organic fractions were combined, washed with brine $(\times 1)$, dried over $\mathrm{MgSO}_{4}$, and concentrated. The crude residue was purified by flash column chromatography (gradient of 20-100\% EtOAc/hexanes) to yield the product as a green solid (0.13 g, $0.50 \mathrm{mmol}, 10 \%) .{ }^{1} \mathbf{H}$ NMR $\left(400 \mathrm{MHz}, \mathrm{CDCl}_{3}, 298 \mathrm{~K}\right): \delta_{\mathrm{H}} 7.90-7.78(\mathrm{~m}, 3 \mathrm{H}), 7.67-$ $7.57(\mathrm{~m}, 2 \mathrm{H}), 7.33-7.22(\mathrm{~m}, 3 \mathrm{H}), 5.71(\mathrm{~d}, J=7.6 \mathrm{~Hz}, 1 \mathrm{H}), 5.68-5.61(\mathrm{~m}, 1 \mathrm{H}), 3.62(\mathrm{dd}, J=17.5$, $8.8 \mathrm{~Hz}, 1 \mathrm{H}), 3.39(\mathrm{dd}, J=17.5,2.4 \mathrm{~Hz}, 1 \mathrm{H}) \mathrm{ppm} ;{ }^{13} \mathbf{C}\left\{{ }^{\mathbf{1}} \mathbf{H}\right\} \mathbf{N M R}\left(100 \mathrm{MHz}, \mathrm{CDCl}_{3}, 298 \mathrm{~K}\right): \delta_{\mathrm{C}}$ $162.3,159.5,141.0,139.0,138.5,132.42,132.37,129.4,129.2,127.6,127.3,125.4,123.9$, 122.9, 79.8, 62.0, $38.5 \mathrm{ppm}$; HRMS $m / z$ (DART): calcd for $\mathrm{C}_{17} \mathrm{H}_{13} \mathrm{~N}_{2} \mathrm{O}(\mathrm{M}+\mathrm{H}): 261.1022$; found: 261.1028 ; m.p.: $142-143^{\circ} \mathrm{C} ; \mathbf{R}_{\mathbf{f}}(7: 3$ hexanes/EtOAc; UV): 0.18 .

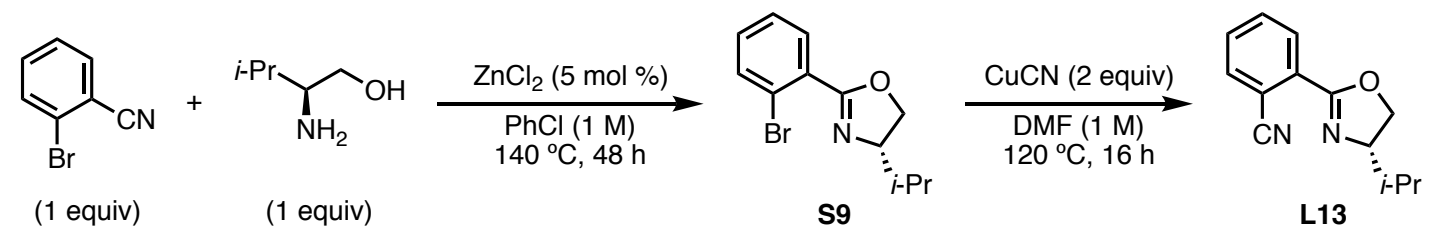

(S)-2-(2-Bromophenyl)-4-isopropyl-4,5-dihydrooxazole (S9): A flame-dried 50-mL two-neck flask was brought into a glovebox and zinc chloride $(68 \mathrm{mg}, 0.50 \mathrm{mmol}, 5 \mathrm{~mol} \%)$ was added. The flask was removed from the glovebox and $\mathbf{S 2}(1.8 \mathrm{~g}, 10 \mathrm{mmol}, 1.0$ equiv) and valinol (1.0 g, $10 \mathrm{mmol}, 1.0$ equiv) were added, followed by chlorobenzene $(10 \mathrm{~mL}, 1.0 \mathrm{M})$. The flask was equipped with a condenser and was refluxed at $140{ }^{\circ} \mathrm{C}$ for $48 \mathrm{~h}$. The solution was cooled to r.t. and quenched with sat. aq. $\mathrm{NH}_{4} \mathrm{Cl}$. The solution was extracted with EtOAc $(\times 3)$ and the organic fractions were combined, washed with brine $(\times 1)$, dried over $\mathrm{MgSO}_{4}$, and concentrated. The crude residue was purified by flash column chromatography (gradient of 5\%-10\%

EtOAc/hexanes) to yield the product as an orange oil ( $0.42 \mathrm{~g}, 1.6 \mathrm{mmol}, 16 \%)$. Analytical data: ${ }^{17}$ ${ }^{1} \mathbf{H}$ NMR $\left(400 \mathrm{MHz}, \mathrm{CDCl}_{3}, 298 \mathrm{~K}\right): \delta_{\mathrm{H}} 7.70-7.60(\mathrm{~m}, 2 \mathrm{H}), 7.38-7.24(\mathrm{~m}, 2 \mathrm{H}), 4.50-4.39(\mathrm{~m}$, $1 \mathrm{H}), 4.23-4.12(\mathrm{~m}, 2 \mathrm{H}), 1.99-1.83(\mathrm{~m}, 1 \mathrm{H}), 1.06(\mathrm{~d}, J=6.8 \mathrm{~Hz}, 3 \mathrm{H}), 0.99(\mathrm{~d}, J=6.8 \mathrm{~Hz}, 3 \mathrm{H})$ ppm; ${ }^{13} \mathbf{C}\left\{{ }^{1} \mathbf{H}\right\}$ NMR $\left(100 \mathrm{MHz}, \mathrm{CDCl}_{3}, 298 \mathrm{~K}\right): \delta_{\mathrm{C}} 162.9,133.7,131.5,131.3,130.2,127.1$, 121.8, 73.0, 70.4, 32.7, 18.8, 18.3 ppm; $\mathbf{R}_{\mathbf{f}}(8: 2$ hexanes/EtOAc; UV): 0.49.

(S)-2-(4-Isopropyl-4,5-dihydrooxazol-2-yl)benzonitrile (L13): Caution: Proper care was taken with cyanide handling (see safety note on page S10). To a flame-dried 8-mL culture tube with stir bar was added $\mathbf{S 9}(0.27 \mathrm{~g}, 1.0 \mathrm{mmol}, 1.0$ equiv) and copper(I) cyanide $(0.18 \mathrm{~g}, 2.0 \mathrm{mmol}, 2.0$ equiv). The tube was covered with a size-19 septum and was evacuated and backfilled with $\mathrm{N}_{2}$ $(\times 3)$ and DMF $(1.0 \mathrm{~mL}, 1.0 \mathrm{M})$ was added. The reaction was stirred at $120^{\circ} \mathrm{C}$ for $16 \mathrm{~h}$. The reaction was cooled to r.t., quenched with sat. aq. $\mathrm{NaHCO}_{3}$, and extracted with EtOAc $(\times 3)$. The organic fractions were combined, washed with $\mathrm{H}_{2} \mathrm{O}(\times 1)$, dried over $\mathrm{MgSO}_{4}$, and concentrated. 
The crude residue was purified by flash column chromatography (gradient of $20-40 \%$ EtOAc/hexanes) to yield the product as a white solid (30 $\mathrm{mg}, 0.14 \mathrm{mmol}, 14 \%)$. Analytical data: ${ }^{18}{ }^{1} \mathrm{H}$ NMR $\left(400 \mathrm{MHz}, \mathrm{CDCl}_{3}, 298 \mathrm{~K}\right): \delta_{\mathrm{H}} 8.07-7.98(\mathrm{~m}, 1 \mathrm{H}), 7.80-7.74(\mathrm{~m}, 1 \mathrm{H}), 7.67-$ $7.59(\mathrm{~m}, 1 \mathrm{H}), 7.59-7.51(\mathrm{~m}, 1 \mathrm{H}), 4.54-4.44(\mathrm{~m}, 1 \mathrm{H}), 4.26-4.14(\mathrm{~m}, 2 \mathrm{H}), 1.96-1.81(\mathrm{~m}, 1 \mathrm{H})$, $1.07(\mathrm{~d}, J=6.8 \mathrm{~Hz}, 3 \mathrm{H}), 0.98(\mathrm{~d}, J=6.8 \mathrm{~Hz}, 3 \mathrm{H}) \mathrm{ppm} ;{ }^{13} \mathbf{C}\left\{{ }^{1} \mathbf{H}\right\} \mathbf{N M R}\left(100 \mathrm{MHz}, \mathrm{CDCl}_{3}, 298\right.$ $\mathrm{K}): \delta_{\mathrm{C}} 160.7,134.6,132.3,131.1,130.5,130.0,117.8,111.9,73.2,71.0,33.0,18.8,18.4 \mathrm{ppm} ; \mathbf{R}_{\mathbf{f}}$ (9:1 hexanes/EtOAc; $\left.\mathrm{UV} / \mathrm{KMnO}_{4}\right): 0.16$.

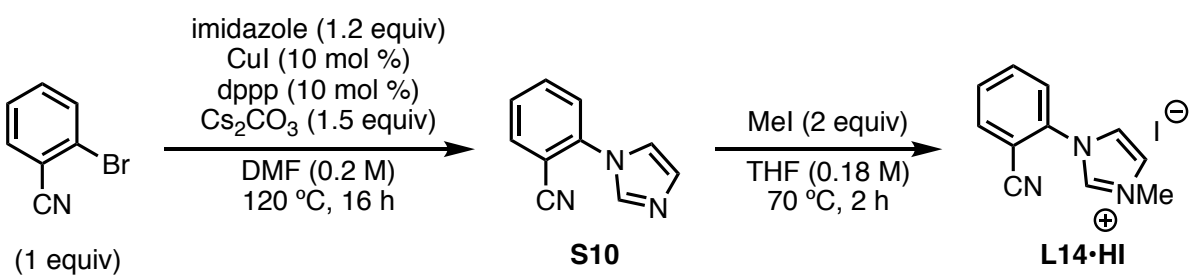

2-(1H-Imidazol-1-yl)benzonitrile (S10): To a flame-dried 50-mL round-bottom flask with stir bar were added 2-bromobenzonitrile $(0.55 \mathrm{~g}, 3.0 \mathrm{mmol}, 1.0$ equiv), imidazole $(0.25 \mathrm{~g}, 3.6 \mathrm{mmol}$, 1.2 equiv), copper(I) iodide ( $57 \mathrm{mg}, 0.30 \mathrm{mmol}, 10 \mathrm{~mol} \%)$, dppp ( $0.12 \mathrm{~g}, 0.30 \mathrm{mmol}, 10 \mathrm{~mol}$ $\%$ ), and cesium carbonate ( $1.5 \mathrm{~g}, 4.5 \mathrm{mmol}, 1.5$ equiv). The flask was sealed, evacuated and backfilled with nitrogen $(\times 3)$, and DMF $(15 \mathrm{~mL}, 0.20 \mathrm{M})$ was added. The reaction was stirred at $120^{\circ} \mathrm{C}$ for $16 \mathrm{~h}$. The reaction was cooled to r.t., quenched with sat. aq. $\mathrm{NH}_{4} \mathrm{Cl}$, and extracted with EtOAc $(\times 3)$. The organic fractions were combined, washed with brine $(\times 1)$, dried over $\mathrm{MgSO}_{4}$, and concentrated. The crude material was used in the next step without further purification.

1-(2-Cyanophenyl)-3-methyl-1 $\mathbf{H}$-imidazol-3-ium iodide (L14•HI): To a flame-dried 25 -mL flask were added $\mathbf{S 1 0}(0.30 \mathrm{~g}, 1.8 \mathrm{mmol}, 1.0$ equiv), THF $(10 \mathrm{~mL}, 0.18 \mathrm{M})$, and iodomethane $\left(0.22 \mathrm{~mL}, 3.6 \mathrm{mmol}, 2.0\right.$ equiv). The reaction was stirred at $70{ }^{\circ} \mathrm{C}$ for $2 \mathrm{~h}$; a white precipitate began forming within $15 \mathrm{~min}$. The reaction was cooled to r.t. The precipitate was filtered out using a fritted funnel and was washed with pentane $(\times 2)$. The solid was purified by recrystallization $\left(\mathrm{MeOH} / \mathrm{Et}_{2} \mathrm{O}\right)$ to yield the product as a beige powder $(0.37 \mathrm{~g}, 1.2 \mathrm{mmol}, 40 \%$ over 2 steps). ${ }^{1} \mathbf{H}$ NMR $\left(400 \mathrm{MHz}\right.$, DMSO- $\left.d_{6}, 298 \mathrm{~K}\right): \delta_{\mathrm{H}} 9.80-9.69(\mathrm{~m}, 1 \mathrm{H}), 8.36-8.29(\mathrm{~m}, 1 \mathrm{H})$, 8.29-8.22 (m, 1H), 8.13-8.02 (m, 2H), 7.99-7.85 (m, 2H), 4.05 (s 3H) ppm; ${ }^{13} \mathbf{C}\left\{{ }^{1} \mathbf{H}\right\}$ NMR $(100$ MHz, DMSO- $\left.d_{6}, 298 \mathrm{~K}\right): \delta_{\mathrm{C}} 138.4,136.8,135.5,135.0,131.8,127.8,124.8,123.9,115.6,109.1$, 36.9 ppm; m.p.: $94-95^{\circ} \mathrm{C}$.

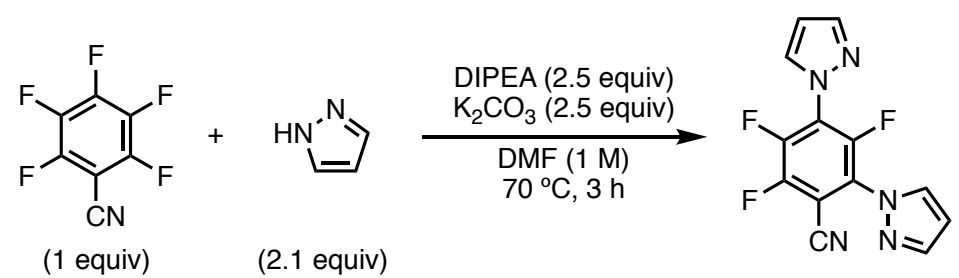

2,3,5-Trifluoro-4,6-di(1 H-pyrazol-1-yl)benzonitrile (L15): To a flame-dried 16-mL culture tube with stir bar were added pyrazole $(0.57 \mathrm{~g}, 8.4 \mathrm{mmol}, 2.1$ equiv) and potassium carbonate (1.4 g, $10 \mathrm{mmol}, 2.5$ equiv). The tube was sealed, evacuated and backfilled with $\mathrm{N}_{2}(\times 3)$, and DMF (4.0 mL, 1.0 M), 2,3,4,5,6-pentafluorobenzonitrile ( $0.50 \mathrm{~mL}, 4.0 \mathrm{mmol}, 1.0$ equiv), and DIPEA $\left(1.7 \mathrm{~mL}, 10 \mathrm{mmol}, 2.5\right.$ equiv) were added. The reaction was stirred for $3 \mathrm{~h}$ at $70^{\circ} \mathrm{C}$. The reaction was cooled to r.t., quenched with $\mathrm{H}_{2} \mathrm{O}$, and extracted with EtOAc $(\times 3)$. The organic 
fractions were combined, washed with brine $(\times 3)$, dried over $\mathrm{MgSO}_{4}$, and concentrated. The crude residue was purified by flash column chromatography (gradient of $10-40 \%$

EtOAc/hexanes) to yield the product as an off-white solid $(0.47 \mathrm{~g}, 1.6 \mathrm{mmol}, 40 \%) .{ }^{1} \mathbf{H} \mathbf{~ N M R}$ $\left(400 \mathrm{MHz}, \mathrm{CDCl}_{3}, 298 \mathrm{~K}\right): \delta_{\mathrm{H}} 7.91-7.75(\mathrm{~m}, 4 \mathrm{H}), 6.63-6.52(\mathrm{~m}, 2 \mathrm{H}) \mathrm{ppm} ;{ }^{19} \mathbf{F}\left\{{ }^{1} \mathbf{H}\right\} \mathbf{N M R}(376$ $\left.\mathrm{MHz}, \mathrm{CDCl}_{3}, 298 \mathrm{~K}\right): \delta_{\mathrm{F}}-129.5,-131.4 ;-139.5 \mathrm{ppm} ;{ }^{13} \mathbf{C}\left\{{ }^{1} \mathbf{H}\right\} \mathbf{N M R}\left(100 \mathrm{MHz}, \mathrm{CDCl}_{3}, 298\right.$ K): $149.7(\mathrm{ddd}, J=259.9,14.4,4.4 \mathrm{~Hz}), 146.0(\mathrm{ddd}, J=255.9,3.8,2.2 \mathrm{~Hz}), 143.9$ (ddd, $J=$ 259.6, 14.4, 3.5 Hz), 143.4, 142.9, 132.3 (dd, $J=2.7,2.7 \mathrm{~Hz}), 131.8$ (d, $J=5.1 \mathrm{~Hz}), 127.4$ (ddd, $J=13.9,4.5,2.0 \mathrm{~Hz}), 124.7(\mathrm{ddd}, J=14.2,11.2,2.8 \mathrm{~Hz}), 109.2(\mathrm{dd}, J=3.4,3.4 \mathrm{~Hz}), 109.1$, 108.8, 99.5 (ddd, $J=15.6,2.4,2.4 \mathrm{~Hz}$ ) ppm; HRMS $m / z$ (DART): calcd for $\mathrm{C}_{13} \mathrm{H}_{7} \mathrm{~N}_{5} \mathrm{~F}_{3}(\mathrm{M}+\mathrm{H})$ : 290.0648; found: 290.0644; m.p.: 89-90 ${ }^{\circ} \mathrm{C}$; $\mathbf{R}_{\mathbf{f}}(8: 2$ hexanes/EtOAc; UV): 0.25.

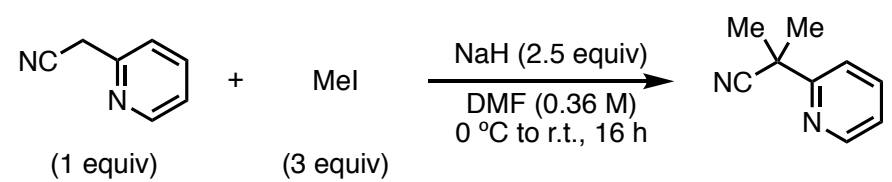

2-Methyl-2-(pyridin-2-yl)propanenitrile (L16): To a flame-dried 50-mL round-bottom flask with stir bar were added sodium hydride $(0.90 \mathrm{~g}$ of a $60 \% \mathrm{w} / \mathrm{w}$ dispersion in mineral oil, 23 mmol, 2.5 equiv) and DMF $(25 \mathrm{~mL}, 0.36 \mathrm{M})$. The solution was cooled to $0^{\circ} \mathrm{C}$ and 2-(pyridin-2yl)acetonitrile $(1.0 \mathrm{~mL}, 8.9 \mathrm{mmol}, 1.0$ equiv) was added. The solution was removed from the cooling bath and was stirred at r.t. for $1.5 \mathrm{~h}$. The solution was cooled to $0{ }^{\circ} \mathrm{C}$ and iodomethane (1.8 $\mathrm{mL}, 27 \mathrm{mmol}, 3.0$ equiv) was added. The solution was removed from the cooling bath and was stirred at r.t. for $16 \mathrm{~h}$. The reaction was quenched with $\mathrm{H}_{2} \mathrm{O}$, extracted with $\mathrm{DCM}(\times 1)$, and the organic fraction was dried over $\mathrm{Na}_{2} \mathrm{SO}_{4}$ and concentrated. The crude residue was purified by flash column chromatography (8:2 hexanes/EtOAc) to yield the product as a colourless oil (1.2 $\mathrm{g}$, $8.2 \mathrm{mmol}, 92 \%)$. Analytical data: ${ }^{19}{ }^{1} \mathbf{H}$ NMR $\left(400 \mathrm{MHz}, \mathrm{CDCl}_{3}, 298 \mathrm{~K}\right): \delta_{\mathrm{H}} 8.65-8.51(\mathrm{~m}, 1 \mathrm{H})$, 7.75-7.66 (m, 1H), 7.61-7.53 (m, 1H), 7.26-7.18 (m, 1H), 1.79-1.72 (m, 6H) ppm; ${ }^{13} \mathbf{C}\left\{{ }^{1} \mathbf{H}\right\}$ NMR (100 MHz, $\left.\mathrm{CDCl}_{3}, 298 \mathrm{~K}\right): \delta_{\mathrm{C}} 159.5,149.5,137.2,124.2,122.7,119.8,39.4,27.8 \mathrm{ppm} ; \mathbf{R}_{\mathbf{f}}$ (8:2 hexanes/EtOAc; UV): 0.50 .

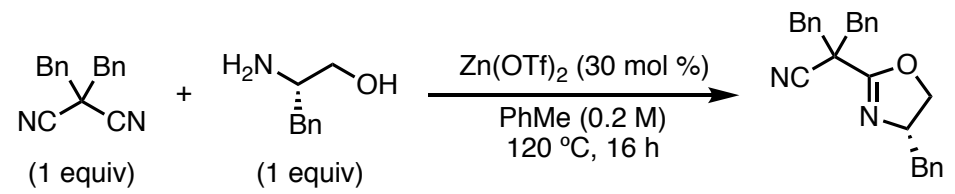

(S)-2-Benzyl-2-(4-benzyl-4,5-dihydrooxazol-2-yl)-3-phenylpropanenitrile (L17): To a flamedried 50-mL Schlenk flask with stir bar were added 2,2-dibenzylmalononitrile (1.3 g, $5.0 \mathrm{mmol}$, 1.0 equiv) and phenylalanol ( $0.76 \mathrm{~g}, 5.0 \mathrm{mmol}, 1.0$ equiv). The flask was sealed and brought into a glovebox and zinc(II) triflate $(0.55 \mathrm{~g}, 1.5 \mathrm{mmol}, 30 \mathrm{~mol} \%)$ was added. The flask was sealed, removed from the glovebox, and $\mathrm{PhMe}(25 \mathrm{~mL}, 0.20 \mathrm{M})$ was added. The reaction was stirred at $120^{\circ} \mathrm{C}$ for $16 \mathrm{~h}$ and was cooled to r.t., quenched with sat. aq. $\mathrm{NH}_{4} \mathrm{Cl}$, and extracted with EtOAc $(\times 3)$. The organic fractions were combined, washed with brine $(\times 1)$, dried over $\mathrm{MgSO}_{4}$, and concentrated. The crude residue was purified by flash column chromatography (gradient of 10$30 \% \mathrm{EtOAc} / \mathrm{hexanes})$ to yield the product as a colourless oil $(0.29 \mathrm{~g}, 0.76 \mathrm{mmol}, 15 \%)$. ${ }^{1} \mathbf{H} \mathbf{~ N M R}$ $\left(400 \mathrm{MHz}, \mathrm{CDCl}_{3}, 298 \mathrm{~K}\right): \delta_{\mathrm{H}} 7.44-7.15(\mathrm{~m}, 13 \mathrm{H}), 7.11-7.03(\mathrm{~m}, 2 \mathrm{H}), 4.32-4.20(\mathrm{~m}, 1 \mathrm{H}), 4.15$ $(\mathrm{dd}, J=9.3,8.4 \mathrm{~Hz}, 1 \mathrm{H}), 3.96(\mathrm{dd}, J=8.4,7.0 \mathrm{~Hz}, 1 \mathrm{H}), 3.27$ (dd, $J=14.6,13.5 \mathrm{~Hz}, 2 \mathrm{H}), 3.17$ (dd, $J=13.5,3.4 \mathrm{~Hz}, 2 \mathrm{H}), 2.93$ (dd, $J=13.8,5.1 \mathrm{~Hz}, 1 \mathrm{H}), 2.26$ (dd, $J=13.7,9.0 \mathrm{~Hz}, 1 \mathrm{H}) \mathrm{ppm}$; ${ }^{13} \mathbf{C}\left\{{ }^{1} \mathbf{H}\right\}$ NMR $\left(100 \mathrm{MHz}, \mathrm{CDCl}_{3}, 298 \mathrm{~K}\right): \delta_{\mathrm{C}} 162.8,137.5,134.4,134.3,130.2,130.1,129.2$, $128.6,128.5,128.5,127.9,127.8,126.6,119.0,72.7,67.5,47.4,43.3,43.1,41.4$ ppm; HRMS 
$m / z$ (DART): calcd for $\mathrm{C}_{26} \mathrm{H}_{25} \mathrm{~N}_{2} \mathrm{O}(\mathrm{M}+\mathrm{H}): 381.1961$; found: $381.1962 ; \mathbf{R}_{\mathbf{f}}(9: 1$ hexanes/EtOAc; $\left.\mathrm{UV} / \mathrm{KMnO}_{4}\right): 0.15$.

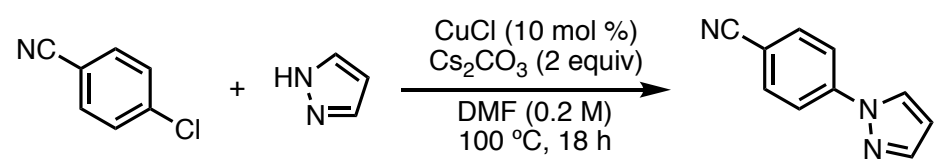

(1.5 equiv) (1 equiv)

4-(1H-Pyrazol-1-yl)benzonitrile (para-L2): To a 50-mL flask were added 4-chlorobenzonitrile ( $2.3 \mathrm{~g}, 7.5 \mathrm{mmol}, 1.5$ equiv), pyrazole ( $0.34 \mathrm{~g}, 5.0 \mathrm{mmol}, 1.0$ equiv), copper(I) chloride (50 mg, $0.50 \mathrm{mmol}, 10 \mathrm{~mol} \%)$, and cesium carbonate ( $3.3 \mathrm{~g}, 10 \mathrm{mmol}, 2.0$ equiv). The flask was sealed, evacuated and backfilled with $\mathrm{N}_{2}(\times 3)$, and DMF $(25 \mathrm{~mL}, 0.20 \mathrm{M})$ was added. The reaction was stirred at $100^{\circ} \mathrm{C}$ for $18 \mathrm{~h}$. The reaction was diluted with DCM, filtered through a pad of silica, washed with brine $(\times 3)$, dried over $\mathrm{MgSO}_{4}$, and concentrated. The crude residue was purified by flash column chromatography (gradient of 0:0:100 to 3:1:7 EtOAc/DCM/hexanes) to yield the product as a white solid (0.82 g, $4.9 \mathrm{mmol}, 98 \%)$. Analytical data: ${ }^{20}{ }^{1} \mathbf{H ~ N M R}\left(400 \mathrm{MHz}, \mathrm{CDCl}_{3}\right.$, $298 \mathrm{~K}): \delta_{\mathrm{H}} 7.99(\mathrm{dd}, J=2.6,0.6 \mathrm{~Hz}, 1 \mathrm{H}), 7.88-7.82(\mathrm{~m}, 2 \mathrm{H}), 7.78-7.73(\mathrm{~m}, 3 \mathrm{H}), 6.54(\mathrm{dd}, J=$ 2.6, $1.8 \mathrm{~Hz}, 1 \mathrm{H}) \mathrm{ppm} ;{ }^{13} \mathbf{C}\left\{{ }^{1} \mathbf{H}\right\} \mathbf{~ N M R}\left(100 \mathrm{MHz}, \mathrm{CDCl}_{3}, 298 \mathrm{~K}\right): \delta_{\mathrm{C}} 142.8,142.6,133.8,126.9$, 119.1, 118.5, 109.8, 109.2 ppm; $\mathbf{R}_{\mathbf{f}}(7: 2: 1$ hexanes/EtOAc/DCM; UV): 0.39.

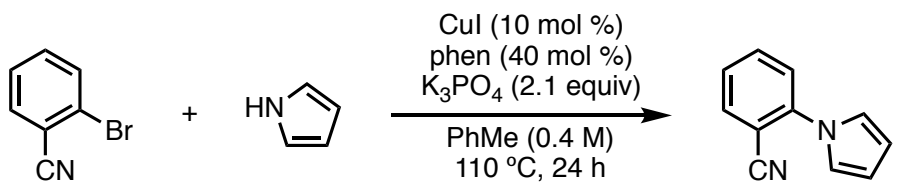

(1.2 equiv) (1 equiv)

2-(1-H-Pyrrol-1-yl)benzonitrile (pyrrolyl-L2): To a flame-dried 100-mL flask was added 2bromobenzonitrile (2.2 g, $12 \mathrm{mmol}, 1.2$ equiv), pyrrole $(0.69 \mathrm{~mL}, 10 \mathrm{mmol}, 1.0$ equiv), copper(I) iodide (0.19 g, $1.0 \mathrm{mmol}, 10 \mathrm{~mol} \%)$, 1,10-phenanthroline (0.72 g, $4.0 \mathrm{mmol}, 40 \mathrm{~mol} \%)$, and potassium phosphate (4.5 g, $21 \mathrm{mmol}, 2.1$ equiv). The flask was sealed, evacuated and backfilled with $\mathrm{N}_{2}(\times 3)$, and $\mathrm{PhMe}(25 \mathrm{~mL}, 0.40 \mathrm{M})$ was added. The reaction was stirred at $110^{\circ} \mathrm{C}$ for $24 \mathrm{~h}$. The solution was cooled to r.t., diluted with EtOAc, filtered through Celite, and the Celite pad was washed with EtOAc $(\times 1)$. The filtrate was concentrated and the crude residue was purified by flash column chromatography (gradient of 0-30\% EtOAc/hexanes) to yield the product as a pale yellow oil (1.1 g, $6.5 \mathrm{mmol}, 65 \%)$. Analytical data: ${ }^{21}{ }^{1} \mathbf{H} \mathbf{~ N M R}\left(400 \mathrm{MHz}, \mathrm{CDCl}_{3}, 298 \mathrm{~K}\right)$ : $\delta_{\mathrm{H}} 7.76(\mathrm{ddd}, J=7.8,1.6,0.5 \mathrm{~Hz}, 1 \mathrm{H}), 7.66(\mathrm{ddd}, J=8.1,7.6,1.6 \mathrm{~Hz}, 1 \mathrm{H}), 7.46-7.36(\mathrm{~m}, 2 \mathrm{H})$, 7.13-7.09 (m, 2H), 6.42-6.40 (m, 2H) ppm; ${ }^{13} \mathbf{C}\left\{{ }^{1} \mathbf{H}\right\} \mathbf{N M R}\left(100 \mathrm{MHz}, \mathrm{CDCl}_{3}, 298 \mathrm{~K}\right): \delta_{\mathrm{C}} 134.7$, 134.5, 134.1, 126.7, 125.3, 121.3, 117.1, 111.4, 107.1 ppm; $\mathbf{R}_{\mathbf{f}}(8: 2$ hexanes/EtOAc; $\left.\mathrm{UV} / \mathrm{KMnO}_{4}\right): 0.40$. 


\section{Procedures for the synthesis of a-arylnitriles}

$\mathrm{PhBr} \underset{\substack{\mathrm{THF}(1.7 \mathrm{M}) \\ \text { r.t., } 6 \mathrm{~h}}}{\stackrel{\mathrm{Mg}(1.2 \text { equiv })}{\mathrm{LiBr}(1.2 \text { equiv })}} \rightarrow \mathrm{PhMgBr}$-LiBr

Phenylmagnesium bromide-lithium bromide complex: To a 50-mL round-bottom flask with a stir bar were added magnesium turnings ( $1.5 \mathrm{~g}, 60 \mathrm{mmol}, 1.2$ equiv). The flask was flame-dried and cooled under vacuum and was then backfilled with $\mathrm{N}_{2}$. The flask was brought into a glovebox and lithium bromide ( $5.2 \mathrm{~g}, 60 \mathrm{mmol}, 1.2$ equiv) was added. The flask was again sealed, removed from the glovebox, and THF $(30 \mathrm{~mL}, 1.67 \mathrm{M})$ was added. The solution was stirred and the magnesium turnings were activated with 1,2-dibromoethane (ca. $0.050 \mathrm{~mL}, 0.60$ mmol). A syringe of bromobenzene $(5.3 \mathrm{~mL}, 50 \mathrm{mmol}, 1.0$ equiv) was added dropwise until initiation was observed (ca. $0.50 \mathrm{~mL}$ added). The remainder of bromobenzene was added portionwise over $2 \mathrm{~h}$ at r.t. under $\mathrm{N}_{2}$, cooling with a water bath as necessary. The reaction was then stirred for an additional $4 \mathrm{~h}$ at r.t. under $\mathrm{N}_{2}$ and was allowed to sit for $1 \mathrm{~h}$ before use. An aliquot was analyzed by GC-MS to confirm full consumption of bromobenzene. The solution was sealed using a septum covered with electrical tape and was stored at r.t. in a fumehood. $\mathrm{PhMgBr} \cdot \mathrm{LiBr}$ was titrated with $\mathrm{I}_{2}$ immediately before use (average of two titrations), and was prepared fresh every four weeks.

Titration of $\mathrm{PhMgBr} \cdot \mathrm{LiBr}$ using $\mathrm{I}_{2}:{ }^{22}$ To an 8 -mL threaded culture tube with a stir bar was added $\mathrm{LiCl}$ (ca. $21 \mathrm{mg}, 0.50 \mathrm{mmol}$ ), and the tube was flame-dried under vacuum and cooled under $\mathrm{N}_{2}$. The tube was briefly opened to air and $\mathrm{I}_{2}$ (ca. $127 \mathrm{mg}, 0.50 \mathrm{mmol}$ ) was added. The precise amount of $\mathrm{I}_{2}$ was recorded. The tube was evacuated and backfilled with $\mathrm{N}_{2}(\times 3)$ and $\mathrm{THF}$ $(2.0 \mathrm{~mL})$ was added. The solution was cooled to $0{ }^{\circ} \mathrm{C}$ and $\mathrm{PhMgBr} \cdot \mathrm{LiBr}$ was added dropwise to the solution. The volume of $\mathrm{PhMgBr} \cdot \mathrm{LiBr}$ required to consume the quantity of $\mathrm{I}_{2}$ and turn the solution colourless was used to calculate the titre of the reagent, which was typically $1.25-$ $1.30 \mathrm{M}$.

\section{Graphical Procedure for preparation of $\mathrm{PhMgBr} \cdot \mathrm{LiBr}$ :}
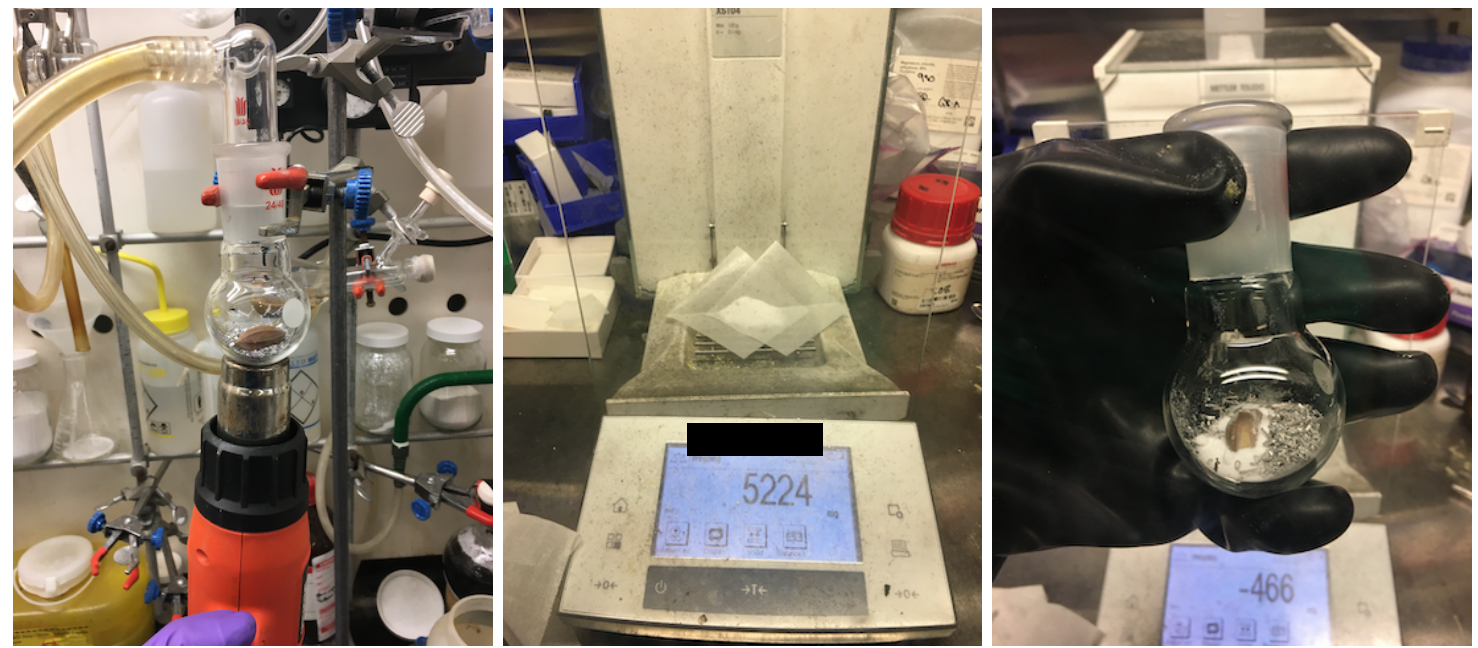

Figure S1. (Left) Flame-drying Mg turnings under high vacuum; (Center) Weighing $\mathrm{LiBr}$ in a glovebox; (Right) Addition of $\mathrm{LiBr}$ to the flask in a glovebox 

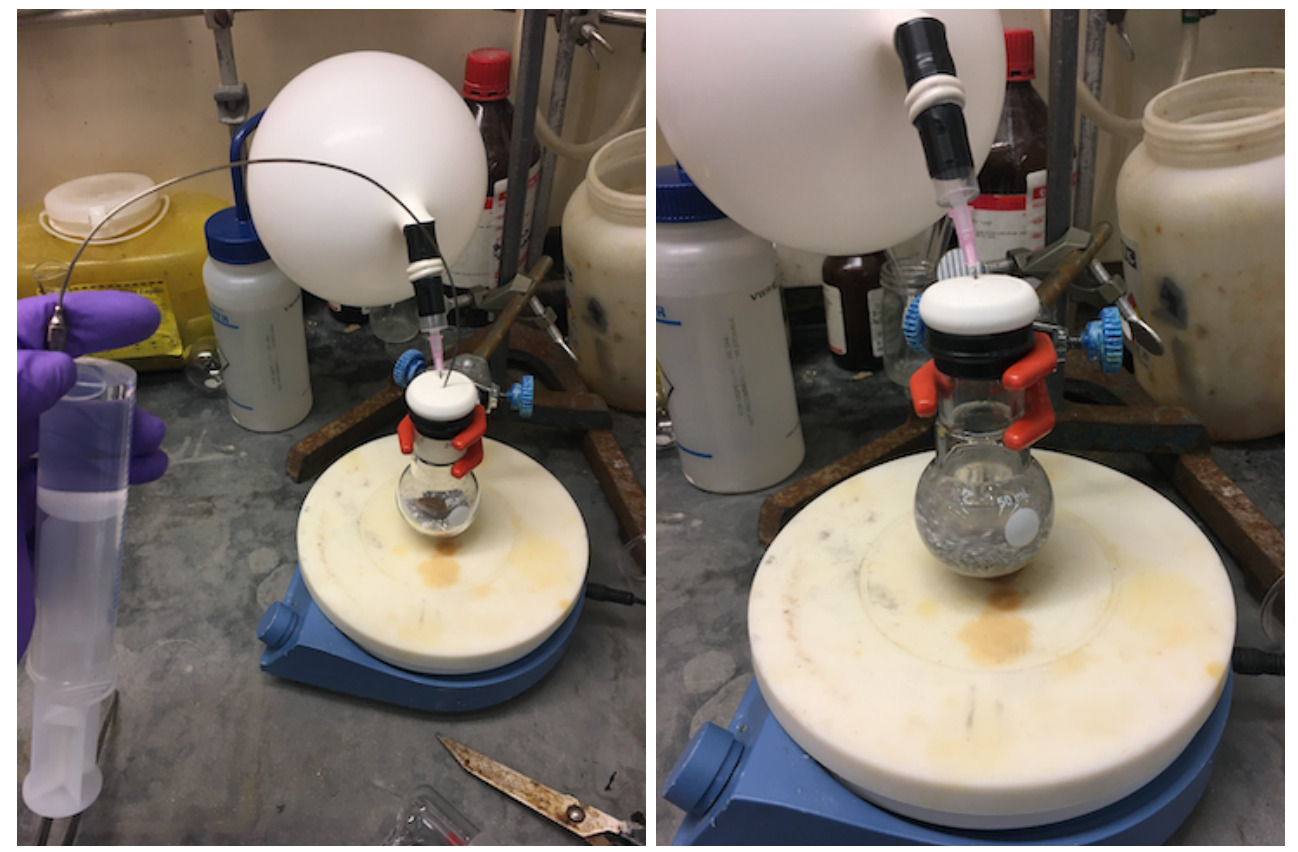

Figure S2. (Left) Flask containing Mg turnings and $\mathrm{LiBr}$ in a fumehood; (Right) Appearance after addition of THF $(30 \mathrm{~mL})$
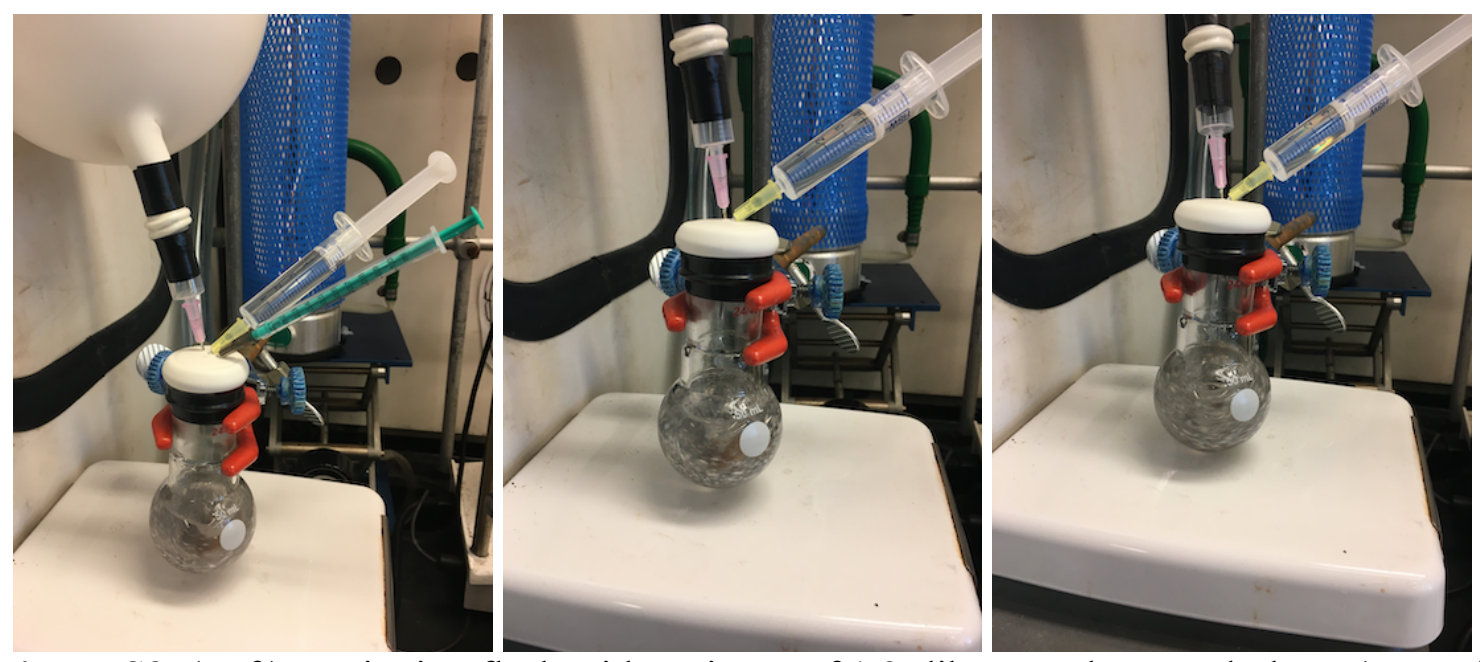

Figure S3. (Left) Equipping flask with syringes of 1,2-dibromoethane and $\mathrm{PhBr}$; (Center) Appearance after addition of 1,2-dibromoethane; (Right) Appearance after initiation is achieved 

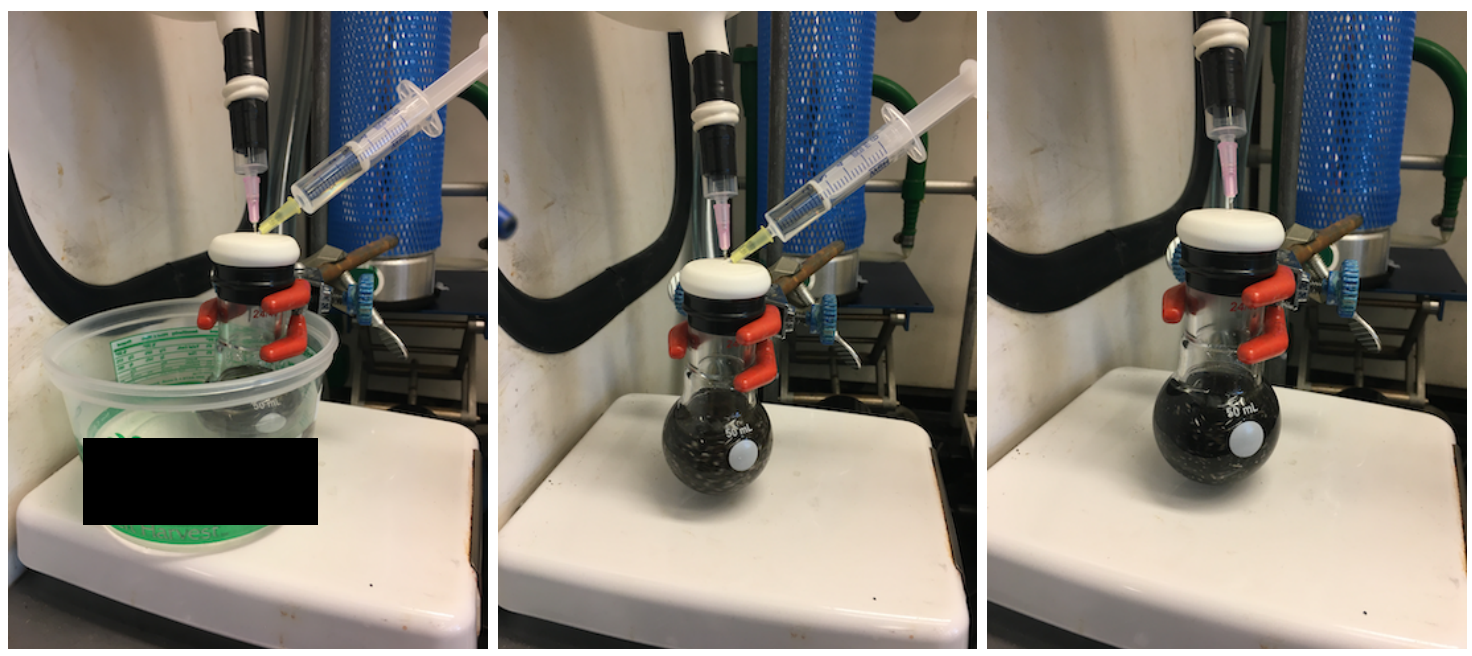

Figure S4. (Left) Cooling with a water bath as necessary; (Center) Appearance halfway through $\mathrm{PhBr}$ addition; (Right) Appearance after complete addition of $\mathrm{PhBr}$

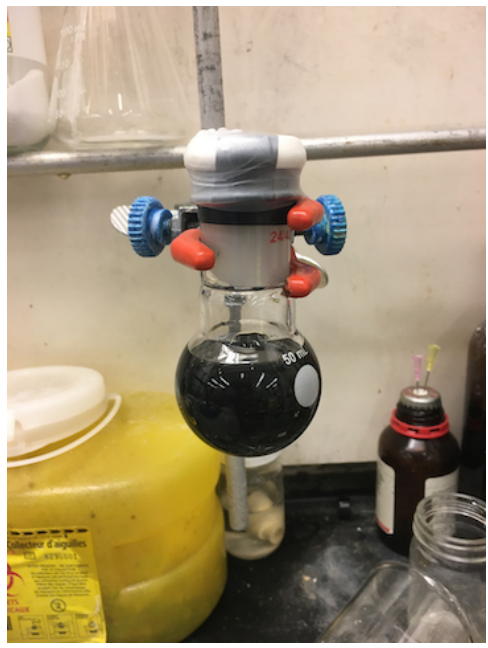

Figure S5. Storage of $\mathrm{PhMgBr} \bullet \mathrm{LiBr}$ in a fumehood 
General Procedure A: Preparation of $\alpha$-arylnitriles (2) from malononitriles (4)

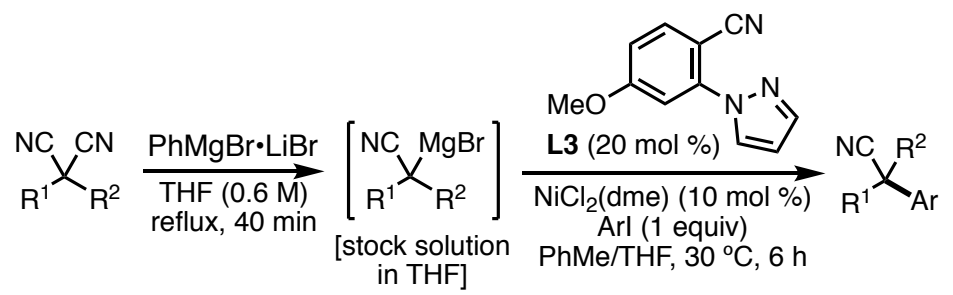

Step 1: A stock solution of the nitrile $\alpha$-anion was generally prepared in a slight excess (e.g., $0.65 \mathrm{mmol}$ ), compared to the prototypical arylation conditions performed on $0.30 \mathrm{mmol}$ scale using $0.54 \mathrm{mmol}$ of nitrile $\alpha$-anion ( $0.54 \mathrm{mmol}, 1.8$ equiv) (vide infra). Thus, to a flame-dried 8 $\mathrm{mL}$ threaded culture tube with a stir bar was added malononitrile (4) (0.65 mmol, 1.0 equiv). The tube was sealed with a size 19 rubber septum and electrical tape and was evacuated and backfilled with $\mathrm{N}_{2}(\times 3)$. For a desired stock solution concentration of $0.60 \mathrm{M}$, the required volume of THF was calculated to be $1.08 \mathrm{~mL}$. The required amount of $\mathrm{PhMgBr} \bullet \mathrm{LiBr}$ was calculated to be $0.51 \mathrm{~mL}(0.51 \mathrm{~mL}$ of a $1.28 \mathrm{M}$ solution in THF, $0.65 \mathrm{mmol}, 1.0$ equiv), and the required amount of additional THF to achieve the total volume of $1.08 \mathrm{~mL}$ was calculated to be $0.57 \mathrm{~mL}(1.08-0.51=0.57 \mathrm{~mL})$. Thus, THF $(0.57 \mathrm{~mL})$ was added, followed by $\mathrm{PhMgBr} \cdot \mathrm{LiBr}$ $(0.51 \mathrm{~mL}$ of a $1.28 \mathrm{M}$ solution in THF, $0.65 \mathrm{mmol}, 1.0$ equiv) (total reaction volume $=1.08 \mathrm{~mL}$, $0.60 \mathrm{M}$ ). The tube was added to a pre-heated $70^{\circ} \mathrm{C}$ oil bath and was stirred at this temperature for $40 \mathrm{~min}$. The solution was removed from the oil bath and was cooled to r.t. using a water bath to yield the nitrile $\alpha$-anion as a $0.60 \mathrm{M}$ stock solution in THF $(0.65 \mathrm{mmol}$ of a $0.60 \mathrm{M}$ stock solution in THF; decyanation-metalation was assumed to be quantitative, see Table S3). The stock solution of nitrile $\alpha$-anion was stable at r.t. in a fumehood over $12 \mathrm{~h}$, however was typically prepared immediately before use. Decyanation-metalation could be scaled up to 5.0-mmol scale without noticeable loss of performance.

Step 2: A 16-mL threaded culture tube was equipped with a size 19 rubber septum and a stir bar and was flame-dried under vacuum and cooled under $\mathrm{N}_{2}$. To the tube were added $\mathbf{L 3}$ (12 $\mathrm{mg}$, $0.060 \mathrm{mmol}, 20 \mathrm{~mol} \%$ ) and aryl iodide (if solid; $0.30 \mathrm{mmol}, 1.0$ equiv). The tube was sealed with the size 19 septum and electrical tape and was evacuated and backfilled with $\mathrm{N}_{2}(\times 3)$. The tube was brought into a glovebox and $\mathrm{NiCl}_{2}(\mathrm{dme})(6.6 \mathrm{mg}, 0.030 \mathrm{mmol}, 10 \mathrm{~mol} \%)$ was added. The tube was again sealed with a septum and electrical tape and was removed from the glovebox. PhMe (7.2 mL, degassed) was added, followed by aryl iodide (if liquid; $0.30 \mathrm{mmol}$, 1.0 equiv). The solution was sonicated for $30 \mathrm{~s}$ to evenly mix the reaction components. The solution was stirred and, while stirring, nitrile $\alpha$-anion $(0.90 \mathrm{~mL}$ of a $0.60 \mathrm{M}$ solution in THF, $0.54 \mathrm{mmol}, 1.8$ equiv) was added (total reaction volume $=8.1 \mathrm{~mL}$ of an $8: 1 \mathrm{PhMe} / \mathrm{THF}$ mixture, $0.037 \mathrm{M}$ ). (After the $\alpha$-anion is added, catalyst activation occurs, and the solution goes from yellow to black in a time-period of 5-10 s.) Immediately after $\alpha$-anion addition, the reaction was placed in a pre-heated $30^{\circ} \mathrm{C}$ oil bath and was stirred for $6 \mathrm{~h}$. The reaction was cooled to r.t., opened to air, and quenched with sat. aq. $\mathrm{NH}_{4} \mathrm{Cl}$. The solution was extracted with EtOAc $(\times 3)$, and the organic fractions were combined, filtered through a plug of $\mathrm{MgSO}_{4}$ and Celite, and concentrated. The crude residue was purified by flash column chromatography to yield $\alpha-$ arylnitrile. 
Graphical procedure for decyanation-metalation (General Procedure A, Step 1):
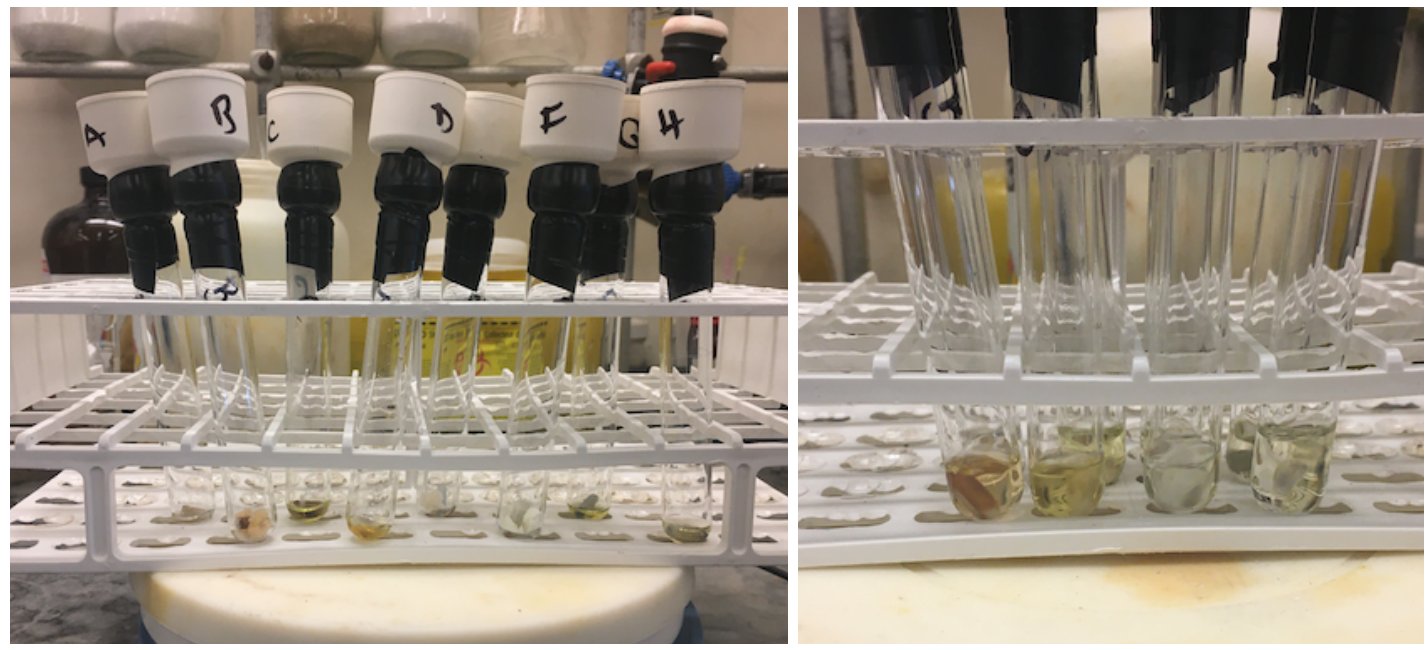

Figure S6. (Left) Reaction tubes containing disubstituted malononitriles; (Right) Appearance after addition of THF
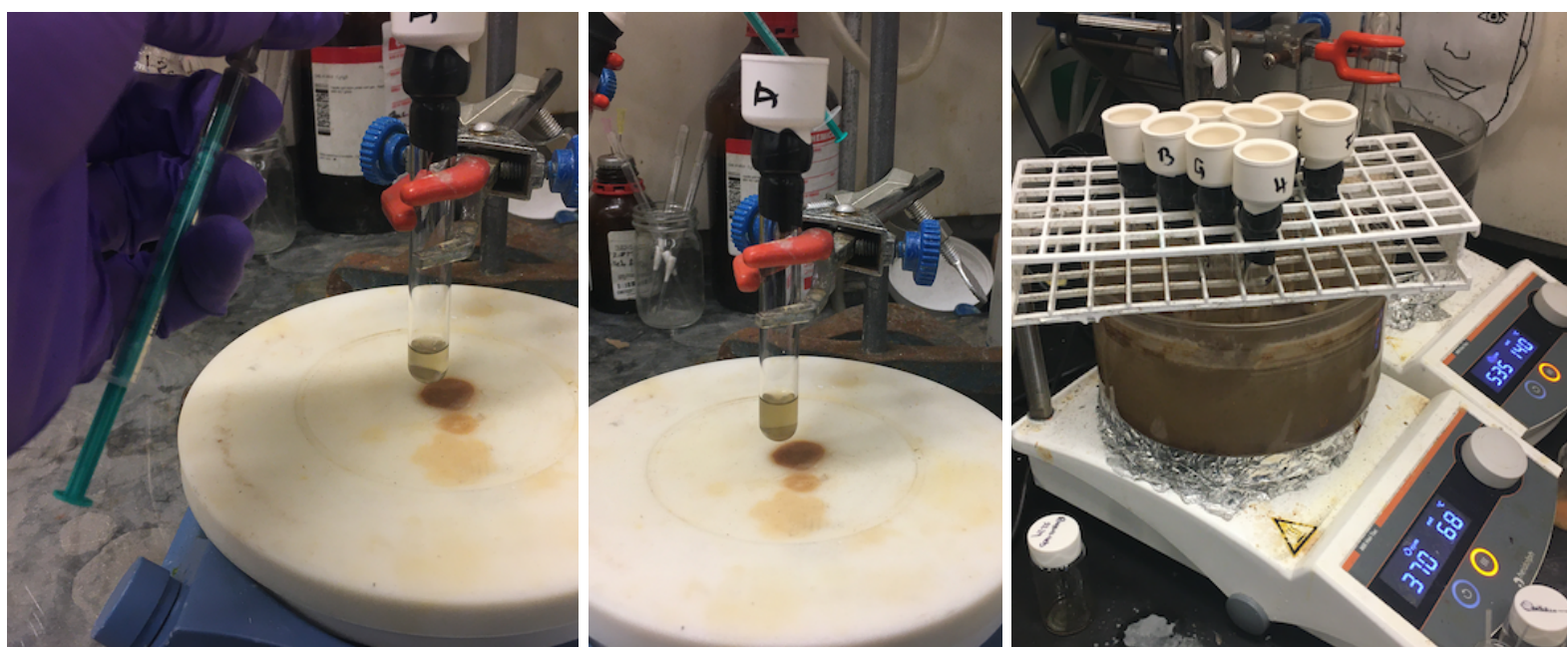

Figure S7. (Left) Addition of $\mathrm{PhMgBr} \bullet \mathrm{LiBr}$ solution; (Center) Appearance after complete addition of $\mathrm{PhMgBr} \cdot \mathrm{LiBr}$; (Right) Performing decyanation-metalation in a pre-heated $70{ }^{\circ} \mathrm{C}$ oil bath 

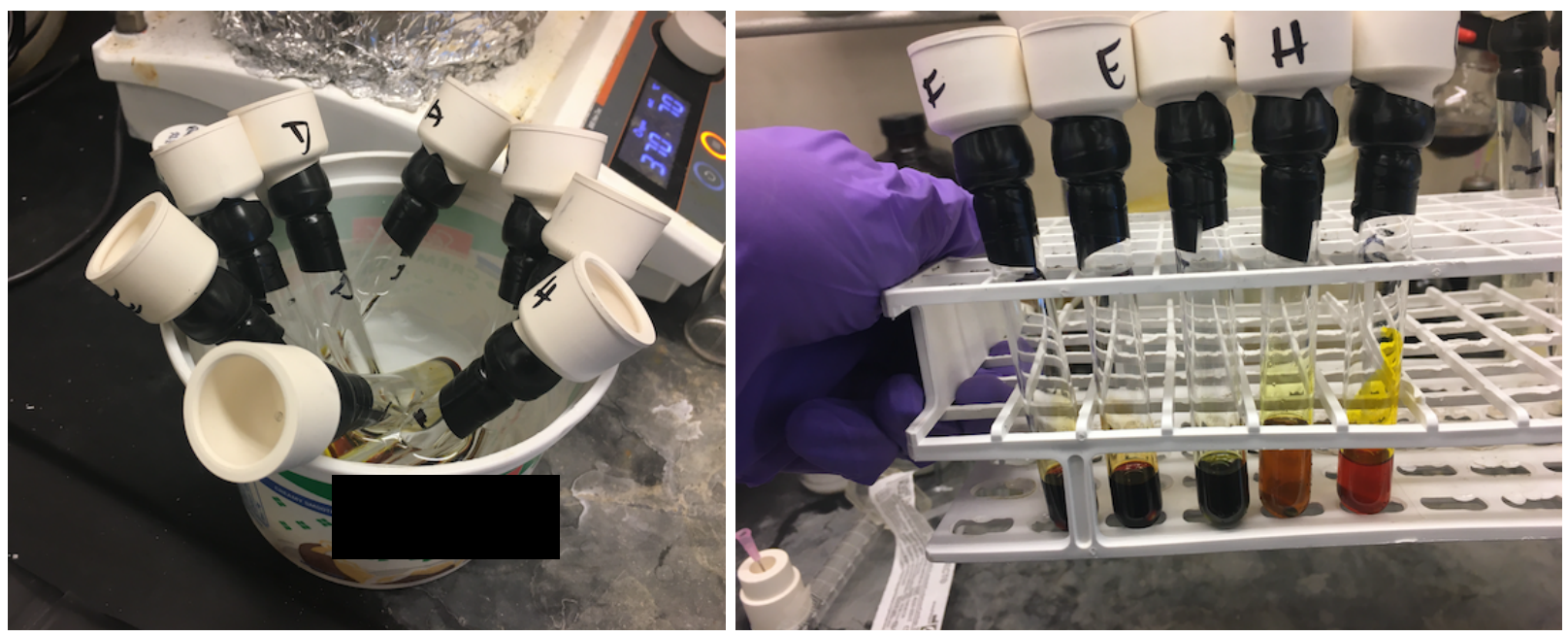

Figure S8. (Left) Cooling $\alpha$-magnesiated nitriles to r.t. in a water bath; (Right) Appearance of $\alpha$ magnesiated nitrile stock solutions

Graphical procedure for Ni-catalyzed $\alpha$-arylation (General Procedure A, Step 2):
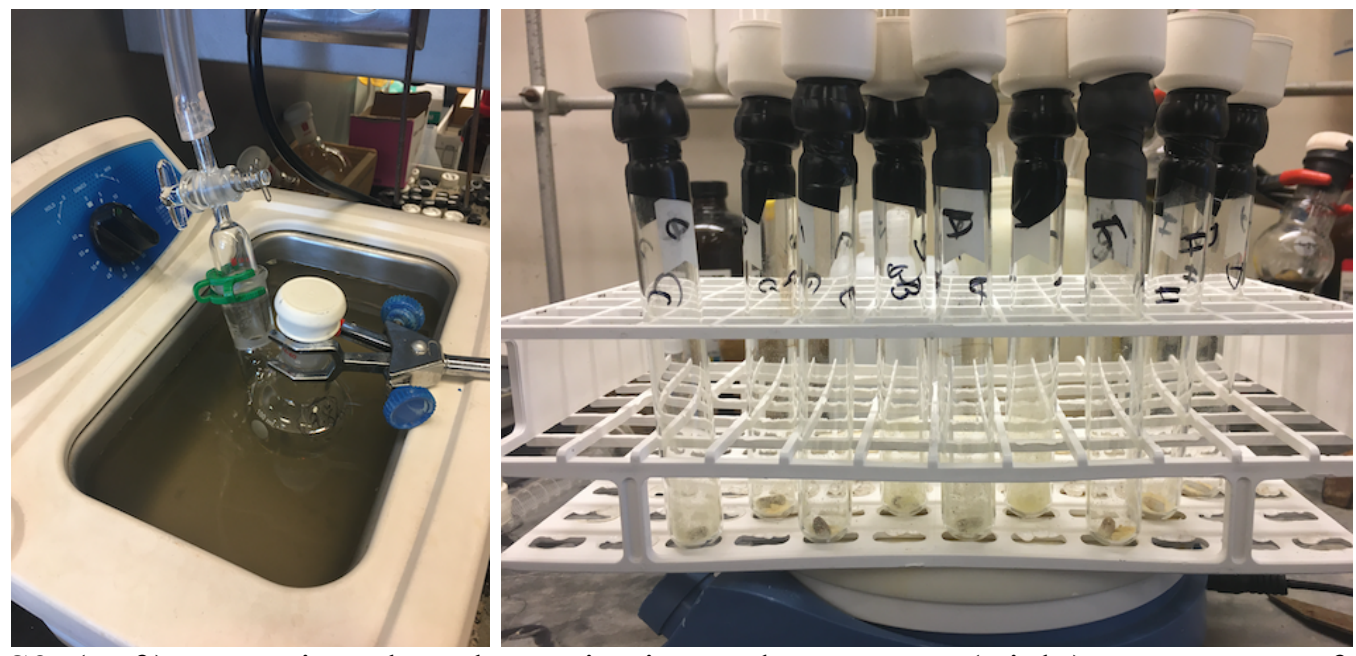

Figure S9. (Left) Degassing PhMe by sonicating under vacuum; (Right) Appearance of reaction tubes after addition of all solids 

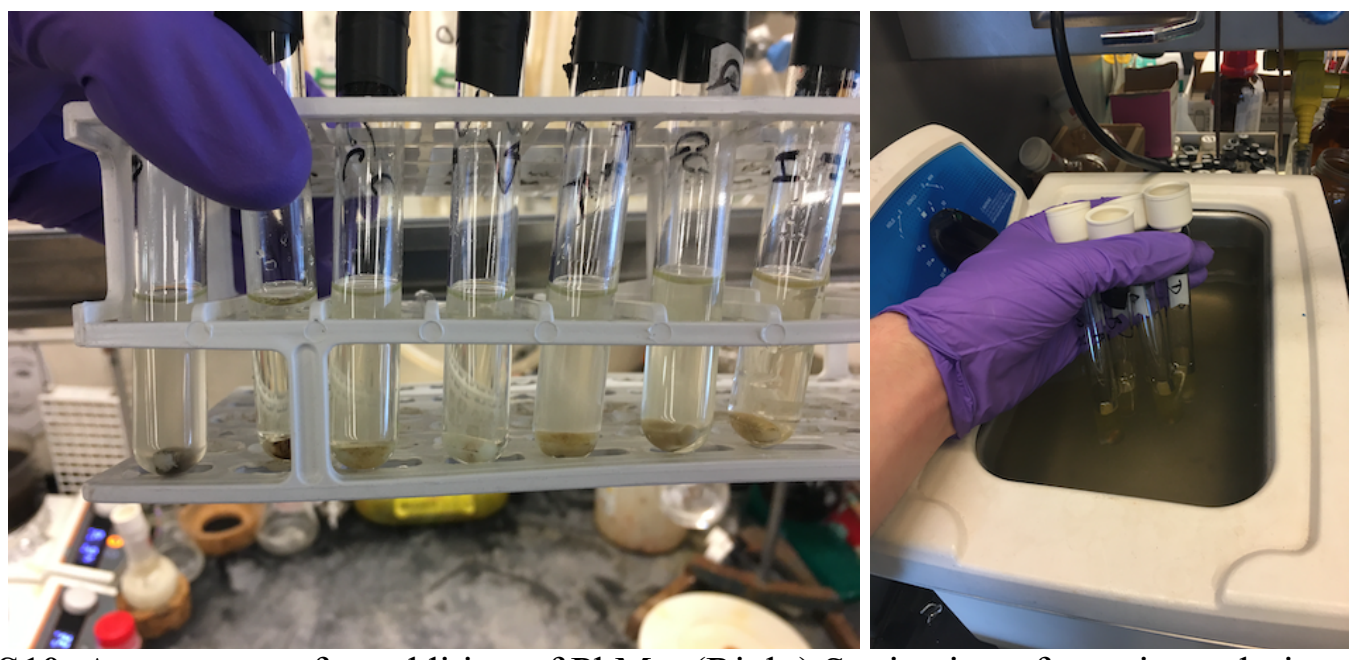

Figure S10. Appearance after addition of PhMe; (Right) Sonication of reaction solutions for $30 \mathrm{~s}$
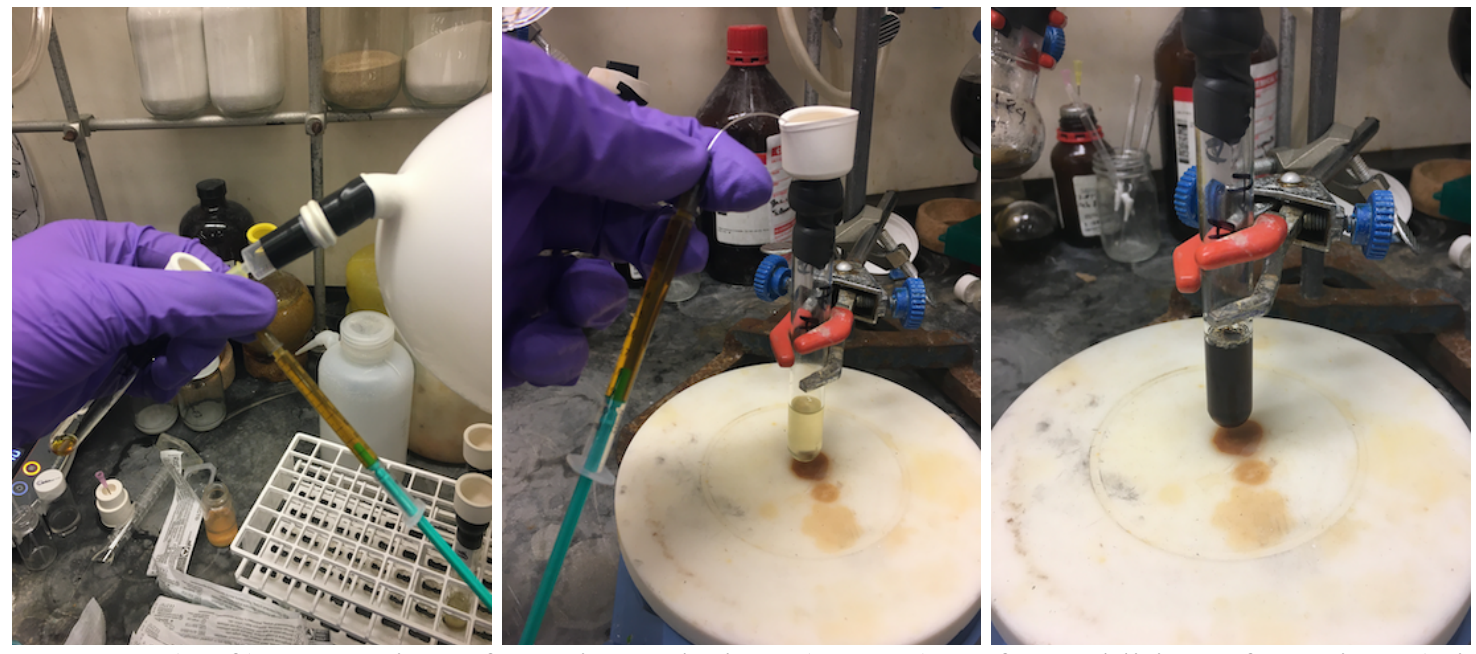

Figure S11. (Left) Extraction of $\alpha$-anion solution; (Center) Before addition of $\alpha$-anion; (Right) After addition of $\alpha$-anion and catalyst activation

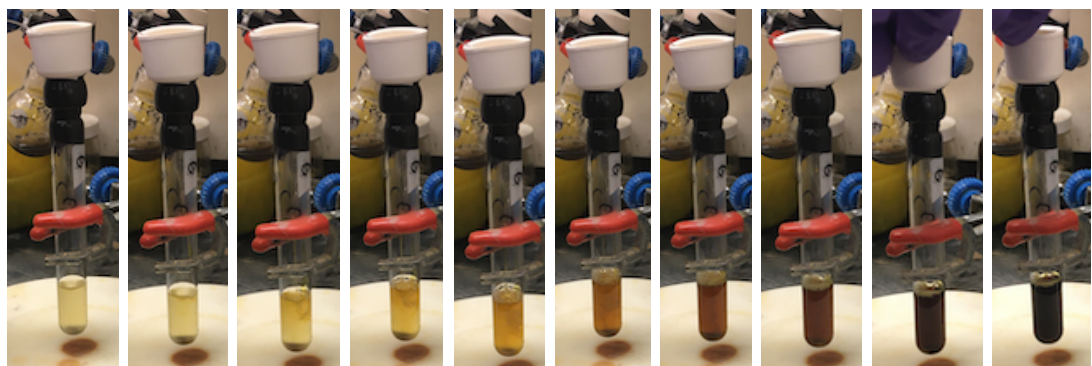

Figure S12. (Left to Right) Colour change after addition of $\alpha$-anion ( $0-10 \mathrm{~s}$ after addition) 


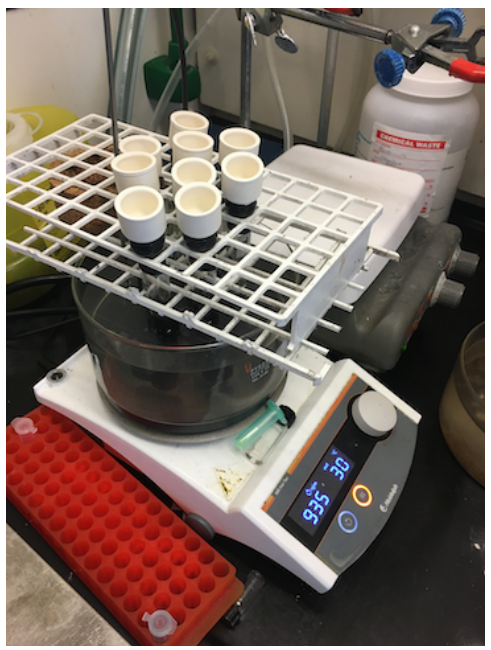

Figure S13. Stirring reactions in a pre-heated $30{ }^{\circ} \mathrm{C}$ oil bath

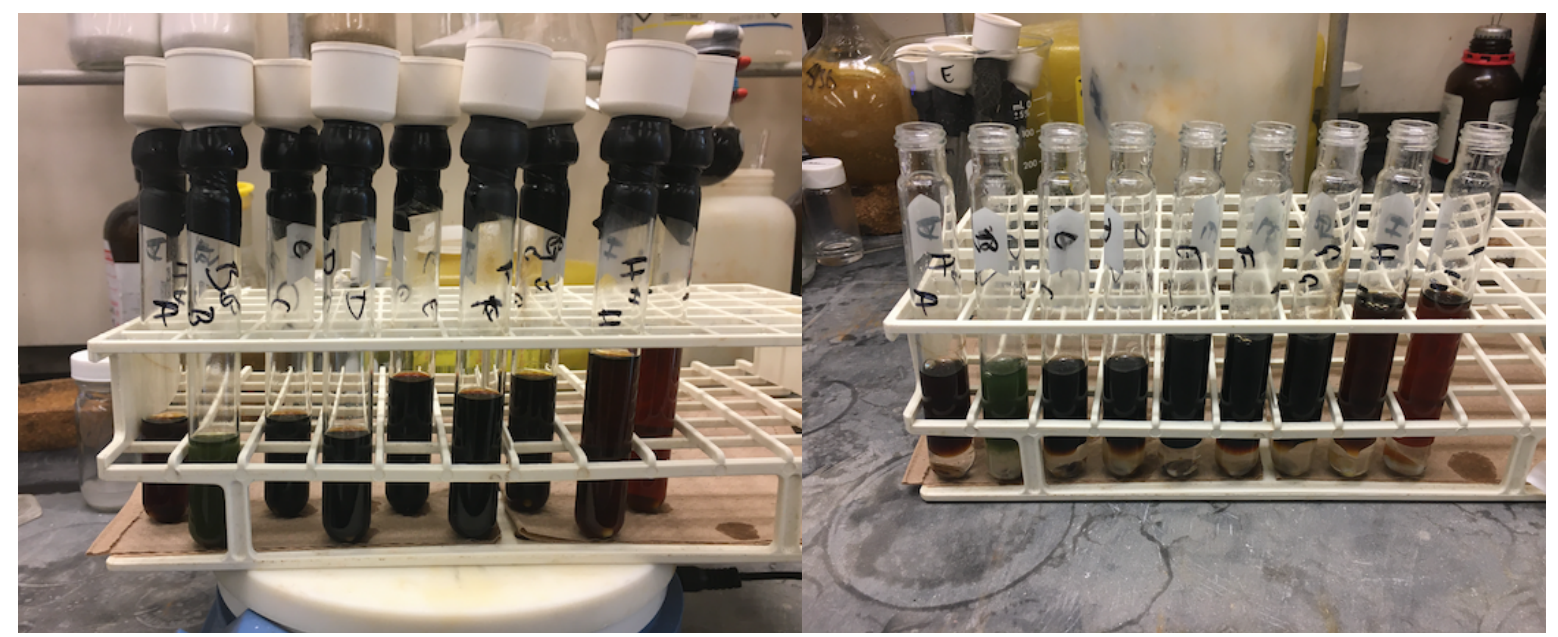

Figure S14. (Left) Appearance of reactions after 6 h; (Right) After addition of sat. aq. $\mathrm{NH}_{4} \mathrm{Cl}$
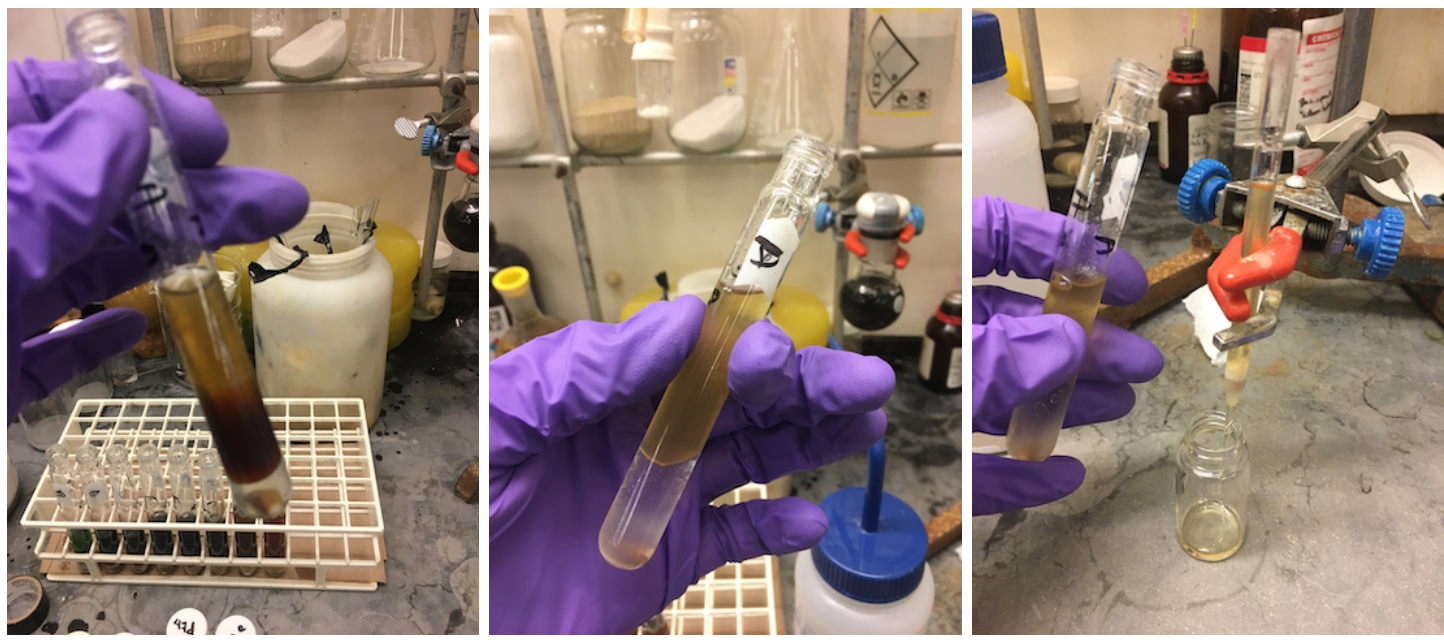

Figure S15. (Left) Appearance during extraction with EtOAc; (Center) Organic layer (top) and aqueous layer (bottom) after mixing; (Right) Filtration of the organic layer over a plug of Celite (bottom later) and $\mathrm{MgSO}_{4}$ (top layer) 

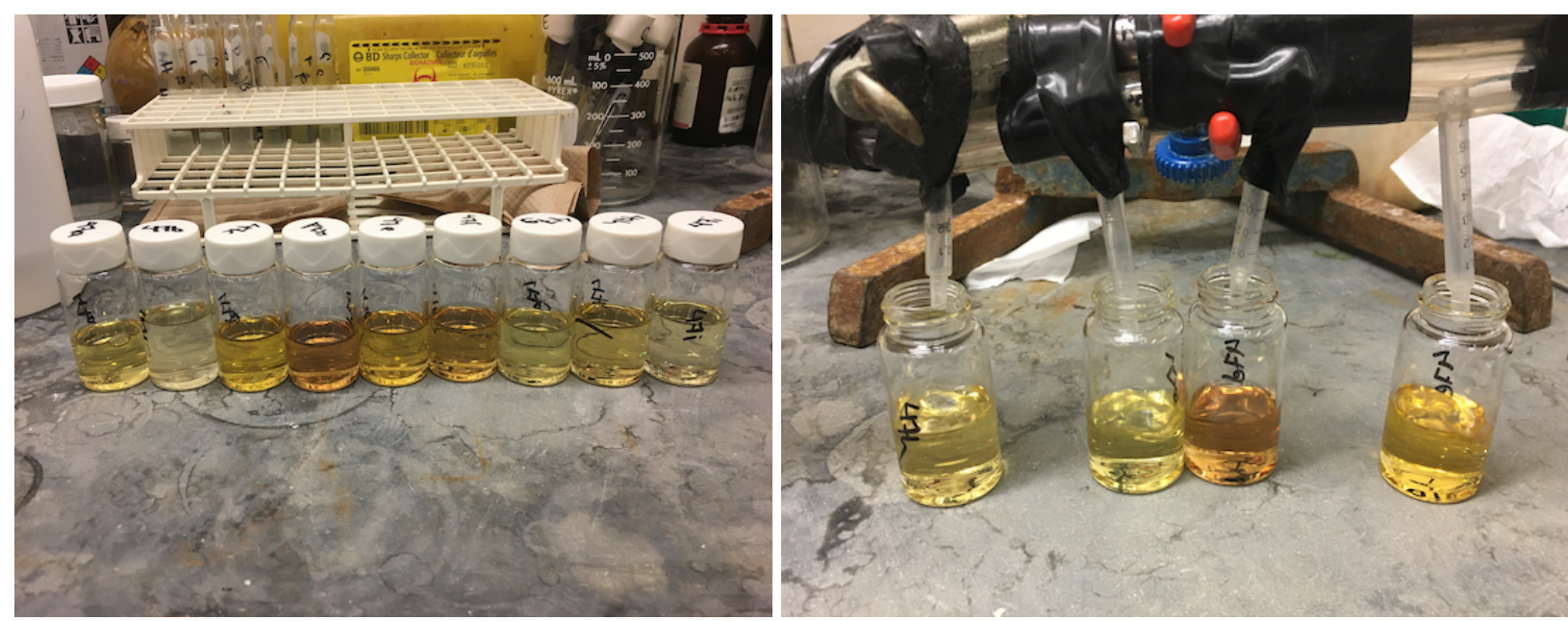

Figure S16. (Left) Appearance after filtration; (Right) Concentration under a stream of compressed air

Table S7. Representative unsuccessful substrates ( $<5 \%$ yield)

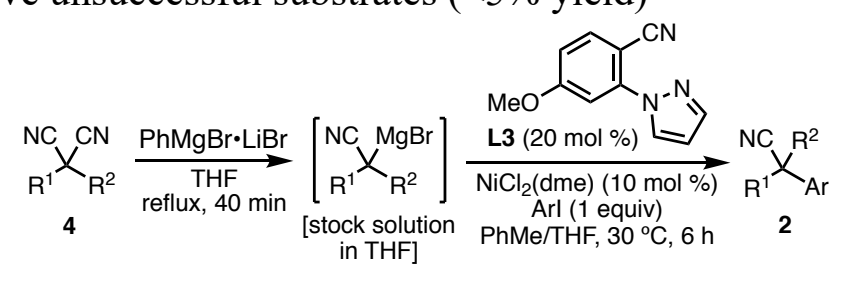

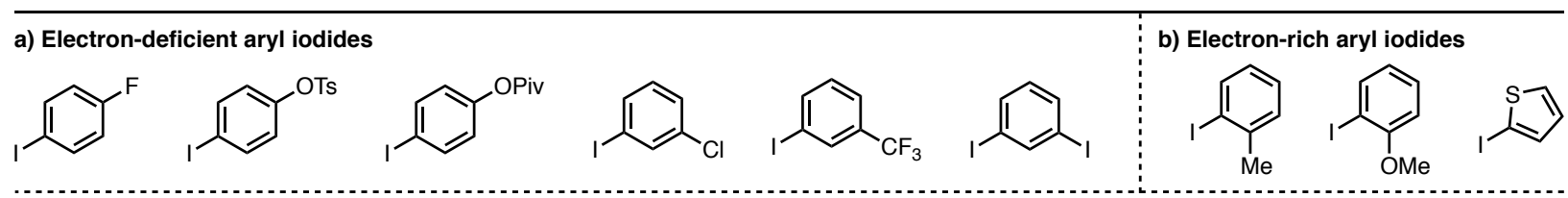

c) Aryl iodides with labile/incompatible functional groups
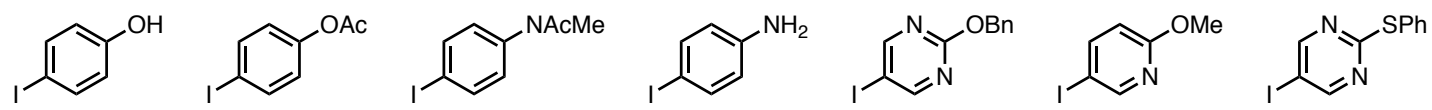

d) Electron-rich and bulky malononitriles<smiles>COc1ccc(C(C)(C#N)C#N)cc1</smiles><smiles>CCNc1ccc(C(C)(C)C#N)cc1</smiles><smiles>N#Cc1ccc(N2CCCC2)nc1</smiles><smiles>COc1ccccc1C(C)(C)C#N</smiles><smiles>CC(C)(N)c1cccc2cccnc12</smiles>

e) Dialkyl malononitriles

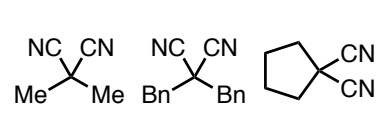<smiles>COc1ccc(C(C)(C)c2ccccc2)cc1</smiles>

2-(4-Methoxyphenyl)-2-phenylpropanenitrile (2a): Prepared on 0.20-mmol scale from 2phenyl-2-methylmalononitrile (4a) (56 mg, $0.36 \mathrm{mmol}, 1.8 \mathrm{equiv}$ ) and 4-iodoanisole (47 $\mathrm{mg}$, $0.20 \mathrm{mmol}, 1.0$ equiv). Arylation was performed using 1.8 equiv of $\alpha$-anion and $\mathrm{PhMe} / \mathrm{THF}$ (10:1). The crude residue was purified by flash column chromatography (gradient of 20-80\% 
$\mathrm{PhMe} /$ hexanes) to yield the product as a colourless oil (39 $\mathrm{mg}, 0.166 \mathrm{mmol}, 83 \%) .{ }^{1} \mathbf{H}$ NMR $\left(500 \mathrm{MHz}, \mathrm{CDCl}_{3}, 298 \mathrm{~K}\right): \delta_{\mathrm{H}} 7.39-7.33(\mathrm{~m}, 4 \mathrm{H}), 7.32-7.27(\mathrm{~m}, 3 \mathrm{H}), 6.90-6.86(\mathrm{~m}, 2 \mathrm{H}), 3.80$ (s, 3H), 2.06 (s, 3H) ppm; ${ }^{13} \mathbf{C}\left\{{ }^{1} \mathbf{H}\right\}$ NMR $\left(125 \mathrm{MHz}, \mathrm{CDCl}_{3}, 298 \mathrm{~K}\right): \delta_{\mathrm{C}} 159.3,141.8,133.4$, 129.0, 128.0, 127.9, 126.7, 123.8, 114.3, 55.5, 45.6, $28.5 \mathrm{ppm}$; HRMS $\mathrm{m} / z$ (DART): calcd for $\mathrm{C}_{16} \mathrm{H}_{19} \mathrm{~N}_{2} \mathrm{O}\left(\mathrm{M}+\mathrm{NH}_{4}\right)$ : 255.1492; found: 255.1495.<smiles>CC(C)(c1ccccc1)c1ccc(OCc2ccccc2)cc1</smiles>

2-(4-(Benzyloxy)phenyl)-2-phenylpropanenitrile (2b): Prepared on 0.30-mmol scale from 2methyl-2-phenylmalononitrile (4a) (84 mg, $0.54 \mathrm{mmol}, 1.8$ equiv) and 1-(benzyloxy)-4iodobenzene (S29) $(93 \mathrm{mg}, 0.30 \mathrm{mmol}, 1.0$ equiv). Arylation was performed using 1.8 equiv $\alpha$ anion and $\mathrm{PhMe} / \mathrm{THF}(8: 1)$. The crude residue was purified by flash column chromatography (gradient of 20-80\% PhMe/hexanes) to yield the product as a colourless oil $(68 \mathrm{mg}, 0.217 \mathrm{mmol}$, 72\%). ${ }^{1} \mathbf{H}$ NMR (500 MHz, $\left.\mathrm{CDCl}_{3}, 298 \mathrm{~K}\right): \delta_{\mathrm{H}} 7.45-7.26(\mathrm{~m}, 12 \mathrm{H}), 6.99-6.93(\mathrm{~m}, 2 \mathrm{H}), 5.06(\mathrm{~s}$, 2H), $2.06(\mathrm{~m}, 3 \mathrm{H}) \mathrm{ppm} ;{ }^{13} \mathbf{C}\left\{{ }^{1} \mathbf{H}\right\} \mathbf{N M R}\left(125 \mathrm{MHz}, \mathrm{CDCl}_{3}, 298 \mathrm{~K}\right): \delta_{\mathrm{C}} 158.5,141.8,136.8$, 133.7, 129.0, 128.8, 128.2, 128.1, 128.0, 127.6, 126.7, 123.7, 115.2, 70.2, 45.7, 28.5 ppm; HRMS $m / z$ (DART): calcd for $\mathrm{C}_{22} \mathrm{H}_{20} \mathrm{NO}(\mathrm{M}+\mathrm{H}): 314.1539$; found: 314.1547 .

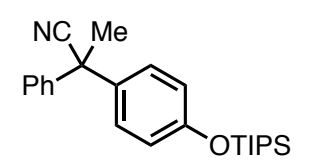

2-Phenyl-2-(4-((triisopropylsilyl)oxy)phenyl)propanenitrile (2c): Prepared on 0.30-mmol scale using 2-methyl-2-phenylmalononitrile (4a) $(84 \mathrm{mg}, 0.54 \mathrm{mmol}, 1.8$ equiv) and (4iodophenoxy)triisopropylsilane (S30) $(93 \mu \mathrm{L}, 0.30 \mathrm{mmol}, 1.0$ equiv). Arylation was performed using 1.8 equiv $\alpha$-anion and PhMe/THF (6:1). The crude residue was purified by flash column chromatography (gradient of $20-60 \% \mathrm{PhMe}$ /hexanes) to yield the product as a colourless oil (71 $\mathrm{mg}, 0.186 \mathrm{mmol}, 62 \%) .{ }^{1} \mathbf{H} \mathbf{N M R}\left(500 \mathrm{MHz}, \mathrm{CDCl}_{3}, 298 \mathrm{~K}\right): \delta_{\mathrm{H}} 7.38-7.27(\mathrm{~m}, 5 \mathrm{H}), 7.23-7.18$ (m, 2H), 6.87-6.83 (m, 2H), 2.05 (s, 3H), 1.25 (hept, $J=7.2 \mathrm{~Hz}, 3 \mathrm{H}), 1.09$ (d, $J=7.4 \mathrm{~Hz}, 18 \mathrm{H})$ ppm; ${ }^{13} \mathbf{C}\left\{{ }^{1} \mathbf{H}\right\}$ NMR $\left(125 \mathrm{MHz}, \mathrm{CDCl}_{3}, 298 \mathrm{~K}\right): \delta_{\mathrm{C}} 155.9,141.9,133.6,128.9,128.0,127.9$, 126.7, 123.9, 120.2, 45.7, 28.5, 18.0, 12.8 ppm; HRMS $m / z$ (DART): calcd for $\mathrm{C}_{24} \mathrm{H}_{37} \mathrm{~N}_{2} \mathrm{OSi}$ $\left(\mathrm{M}+\mathrm{NH}_{4}\right)$ : 397.2670 ; found: 397.2673 .

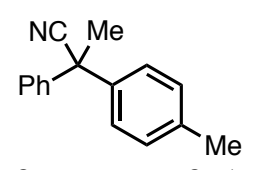

2-Phenyl-2-(p-tolyl)propanenitrile (2d): Prepared on 0.20-mmol scale using 2-methyl-2phenylmalnononitrile (4a) $(56 \mathrm{mg}, 0.36 \mathrm{mmol}, 1.8$ equiv) and 4-iodotoluene (44 mg, $0.20 \mathrm{mmol}$, 1.0 equiv). Arylation was performed using 1.8 equiv $\alpha$-anion and PhMe/THF (10:1). The crude residue was purified by flash column chromatography (gradient of $0-20 \% \mathrm{EtOAc} /$ hexanes) to yield the product as a colourless oil (28 mg, $0.126 \mathrm{mmol}, 63 \%) .{ }^{1} \mathbf{H} \mathbf{~ N M R}\left(400 \mathrm{MHz}, \mathrm{CDCl}_{3}\right.$, $298 \mathrm{~K}): \delta_{\mathrm{H}} 7.41-7.13(\mathrm{~m}, 9 \mathrm{H}), 2.34(\mathrm{~s}, 3 \mathrm{H}), 2.07(\mathrm{~s}, 3 \mathrm{H}) \mathrm{ppm} ;{ }^{13} \mathbf{C}\left\{{ }^{1} \mathbf{H}\right\} \mathbf{~ N M R}\left(100 \mathrm{MHz}, \mathrm{CDCl}_{3}\right.$, $298 \mathrm{~K}): \delta_{\mathrm{C}} 141.5,138.3,137.7,129.5,128.8,127.8,126.6,126.5,123.6,45.8,28.2,20.9 \mathrm{ppm} ; \mathbf{R}_{\mathbf{f}}$ (9:1 hexanes/EtOAc; $\left.\mathrm{KMnO}_{4}\right): 0.59$. 


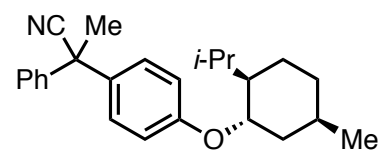

2-(4-(((1S,2R,5R)-2-Isopropyl-5-methylcyclohexyl)oxy)phenyl)-2-phenylpropanenitrile (2e): Prepared on 0.30-mmol scale using 2-methyl-2-phenylmalononitrile (4a) $(84 \mathrm{mg}, 0.54 \mathrm{mmol}, 1.8$ equiv) and 1-iodo-4-(((1S,2R,5R)-2-isopropyl-5-methylcyclohexyl)oxy)benzene (S31) $(70 \mu \mathrm{L}$, $0.30 \mathrm{mmol}, 1.0$ equiv). Arylation was performed using 1.8 equiv $\alpha$-anion and PhMe/THF (6:1). The crude residue was purified by flash column chromatography (gradient of $20-60 \%$ $\mathrm{PhMe} /$ hexanes) to yield the product as a colourless oil, which was a 6:1 mixture of diastereomers (63 mg, $0.174 \mathrm{mmol}, 58 \%)$. Analytical data (major diastereomer): ${ }^{1} \mathbf{H} \mathbf{~ N M R}\left(500 \mathrm{MHz}, \mathrm{CDCl}_{3}\right.$, $298 \mathrm{~K}): \delta_{\mathrm{H}} 7.41-7.33(\mathrm{~m}, 4 \mathrm{H}), 7.32-7.28(\mathrm{~m}, 1 \mathrm{H}), 7.27-7.23(\mathrm{~m}, 2 \mathrm{H}), 6.83-6.83(\mathrm{~m}, 2 \mathrm{H}), 4.02$ $(\mathrm{td}, J=10.6,4.2 \mathrm{~Hz}, 1 \mathrm{H}), 2.22-2.08(\mathrm{~m}, 2 \mathrm{H}), 2.06(\mathrm{~s}, 3 \mathrm{H}), 1.77-1.66(\mathrm{~m}, 3 \mathrm{H}), 1.57-1.39(\mathrm{~m}$, $2 \mathrm{H}), 1.16-0.96(\mathrm{~m}, 2 \mathrm{H}), 0.92(\mathrm{~d}, J=6.9 \mathrm{~Hz}, 6 \mathrm{H}), 0.76(\mathrm{dd}, J=7.0,1.5 \mathrm{~Hz}, 3 \mathrm{H}) \mathrm{ppm} ;{ }^{13} \mathbf{C}\left\{{ }^{1} \mathbf{H}\right\}$ NMR $\left(125 \mathrm{MHz}, \mathrm{CDCl}_{3}, 298 \mathrm{~K}\right): \delta_{\mathrm{C}} 157.9,141.7,132.8,128.8,127.9,127.8,126.5,123.7$, 115.7, 48.0, 45.5, 40.1, 34.4, 31.4, 28.3, 26.1, 23.7, 22.1, 20.7, $16.6 \mathrm{ppm}$; HRMS $\mathrm{m} / z$ (DART): calcd for $\mathrm{C}_{25} \mathrm{H}_{32} \mathrm{NO}(\mathrm{M}+\mathrm{H}): 362.2478$; found: 362.2476 .

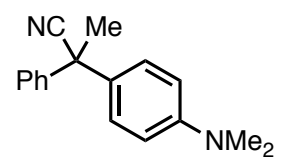

2-(4-(Dimethylamino)phenyl)-2-phenylpropanenitrile (2f): Prepared on 0.30-mmol scale using 2-methyl-2-phenylmalononitrile (4a) $(84 \mathrm{mg}, 0.54 \mathrm{mmol}, 1.8$ equiv) and 4-iodo- $N, N$ dimethylaniline (S33) (74 mg, $0.30 \mathrm{mmol}, 1.0$ equiv). Arylation was performed using 1.8 equiv $\alpha$-anion and $\mathrm{PhMe} / \mathrm{THF}$ (4:1). The crude residue was purified by flash column chromatography (gradient of $15-40 \% \mathrm{PhMe} /$ hexanes) to yield the product as a colourless oil $(63 \mathrm{mg}, 0.252 \mathrm{mmol}$, $84 \%)$. The product was unstable at r.t. over 1 month. ${ }^{1} \mathbf{H}$ NMR $\left(500 \mathrm{MHz}, \mathrm{CDCl}_{3}, 298 \mathrm{~K}\right): \delta_{\mathrm{H}}$ 7.41-7.32 (m, 4H), 7.31-7.27 (m, 1H), 7.24-7.19 (m, 2H), 6.70-6.63 (m, 2H), 2.95 (s, 6H), 2.05 (s, 3H) ppm; $\left.{ }^{13} \mathbf{C}_{\{}{ }^{1} \mathbf{H}\right\}$ NMR $\left(125 \mathrm{MHz}, \mathrm{CDCl}_{3}, 298 \mathrm{~K}\right): \delta_{\mathrm{C}} 150.0,142.3,129.5,128.9,127.7$, 127.6, 126.7, 124.1, 112.4, 45.5, 40.5, $28.4 \mathrm{ppm}$; HRMS $m / z$ (DART): calcd fro $\mathrm{C}_{17} \mathrm{H}_{19} \mathrm{~N}_{2}$ $(\mathrm{M}+\mathrm{H}): 251.1543$; found: 251.1547 .

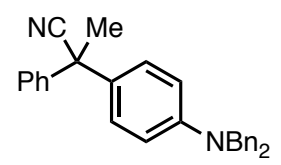

2-(4-(Dibenzylamino)phenyl)-2-phenylpropanenitrile (2g): Prepared on 0.30-mmol scale using 2-methyl-2-phenylmalononitrile (4a) (84 $\mathrm{mg}, 0.54 \mathrm{mmol}, 1.8$ equiv) and $N, N$-dibenzyl-4iodoaniline (S32) $(0.12 \mathrm{~g}, 0.30 \mathrm{mmol}, 1.0$ equiv). Arylation was performed using 1.8 equiv $\alpha-$ anion and $\mathrm{PhMe} / \mathrm{THF}$ (4:1). The crude residue was purified by flash column chromatography (gradient of 5-30\% PhMe/hexanes) to yield the product as a yellow oil $(70 \mathrm{mg}, 0.174 \mathrm{mmol}$, 58\%). ${ }^{1} \mathbf{H}$ NMR $\left(500 \mathrm{MHz}, \mathrm{CDCl}_{3}, 298 \mathrm{~K}\right): \delta_{\mathrm{H}} 7.41-7.30(\mathrm{~m}, 8 \mathrm{H}), 7.30-7.21(\mathrm{~m}, 7 \mathrm{H}), 7.14-7.10$ (m, 2H), 6.70-6.66 (m, 2H), $4.64(\mathrm{~s}, 4 \mathrm{H}), 2.02(\mathrm{~s}, 3 \mathrm{H}) \mathrm{ppm} ;{ }^{13} \mathbf{C}\left\{{ }^{1} \mathbf{H}\right\}$ NMR $\left(125 \mathrm{MHz}, \mathrm{CDCl}_{3}\right.$, $298 \mathrm{~K}): \delta_{\mathrm{C}} 148.7,142.1,138.4,129.3,129.0,128.9,127.7,127.2,126.9,126.7,126.7,124.1$, 112.5, 54.4, 45.5, 28.4 ppm; HRMS $m / z$ (DART): calcd for $\mathrm{C}_{29} \mathrm{H}_{27} \mathrm{~N}_{2}(\mathrm{M}+\mathrm{H})$ : 403.2169; found: 403.2176 . 
${ }_{\mathrm{Ph}}^{\mathrm{NC}} \mathrm{X}_{\mathrm{Ph}}^{\mathrm{Me}}$

2,2-Diphenylpropanenitrile (2h): Prepared on 0.20-mmol scale using 2-methyl-2-

phenylmalononitrile (4a) (56 mg, $0.36 \mathrm{mmol}, 1.8$ equiv) and iodobenzene ( $22 \mu \mathrm{L}, 0.20 \mathrm{mmol}$, 1.0 equiv). Arylation was performed using 1.8 equiv $\alpha$-anion and $\mathrm{PhMe} / \mathrm{THF}(10: 1)$. The crude residue was purified by flash column chromatography (gradient of 0-20\% EtOAc/hexanes) to yield the product as a colourless oil $(15 \mathrm{mg}, 0.070 \mathrm{mmol}, 35 \%)$. Analytical data: ${ }^{23}{ }^{1} \mathbf{H}$ NMR (400 $\left.\mathrm{MHz}, \mathrm{CDCl}_{3}, 298 \mathrm{~K}\right): \delta_{\mathrm{H}} 7.43-7.29(\mathrm{~m}, 10 \mathrm{H}), 2.10(\mathrm{~s}, 3 \mathrm{H}) \mathrm{ppm} ;{ }^{13} \mathbf{C}\left\{{ }^{1} \mathbf{H}\right\} \mathbf{N M R}(100 \mathrm{MHz}$, $\left.\mathrm{CDCl}_{3}, 298 \mathrm{~K}\right): \delta_{\mathrm{C}} 141.4,129.0,128.0,126.8,123.6,46.3,28.3 \mathrm{ppm}$.

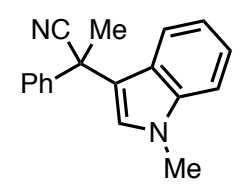

2-(1-Methyl-1H-indol-3-yl)-2-phenylpropanenitrile (2i): Prepared on 0.20-mmol scale using 2-methyl-2-phenylmalononitrile (4a) (56 mg, $0.36 \mathrm{mmol}, 1.8$ equiv) and 3-iodo-1-methyl- $1 \mathrm{H}$ indole (S34) (51 mg, $0.20 \mathrm{mmol}, 1.0$ equiv). Arylation was performed using 1.8 equiv $\alpha$-anion and $\mathrm{PhMe} / \mathrm{THF}$ (10:1). The crude residue was purified by flash column chromatography (gradient of 0-20\% EtOAc/hexanes) to yield the product as a colourless oil (31 $\mathrm{mg}, 0.119 \mathrm{mmol}$, $60 \%) .{ }^{1} \mathbf{H}$ NMR $\left(400 \mathrm{MHz}, \mathrm{CDCl}_{3}, 298 \mathrm{~K}\right): \delta_{\mathrm{H}} 7.52-7.43(\mathrm{~m}, 2 \mathrm{H}), 7.42-7.25(\mathrm{~m}, 5 \mathrm{H}), 7.24-7.17$ $(\mathrm{m}, 1 \mathrm{H}), 7.07-6.97(\mathrm{~m}, 2 \mathrm{H}), 3.76(\mathrm{~s}, 3 \mathrm{H}), 2.14(\mathrm{~s}, 3 \mathrm{H}) \mathrm{ppm} ;{ }^{13} \mathbf{C}\left\{{ }^{1} \mathbf{H}\right\} \mathbf{N M R}\left(100 \mathrm{MHz}, \mathrm{CDCl}_{3}\right.$, $298 \mathrm{~K}): \delta_{\mathrm{C}} 141.3,137.8,129.4,128.8,127.8,127.1,126.2,123.2,122.3,120.3,119.7,114.7$, 109.6, 40.7, 33.0, 28.7 ppm; HRMS (DART): calcd for $\mathrm{C}_{18} \mathrm{H}_{17} \mathrm{~N}_{2}(\mathrm{M}+\mathrm{H})$ : 261.1386; found: 261.1397.<smiles>CCCCOc1ccc(C(C)(C)c2cccc(C(F)(F)F)c2)cc1</smiles>

2-(4-(Benzyloxy)phenyl)-2-(3-(trifluoromethyl)phenyl)propanenitrile (2j): Prepared on 0.30mmol scale using 2-methyl-2-(3-(trifluoromethyl)phenyl)malononitrile (S13) (0.12 g, 0.54 mmol, 1.8 equiv) and 1-(benzyloxy)-4-iodobenzene (S29) $(93 \mathrm{mg}, 0.30 \mathrm{mmol}, 1.0$ equiv). Arylation was performed using 1.8 equiv $\alpha$-anion and PhMe/THF (8:1). The crude residue was purified by flash column chromatography (gradient of 0-30\% EtOAc/hexanes) to yield the product as a colourless oil (93 mg, $0.244 \mathrm{mmol}, 81 \%) .{ }^{1} \mathbf{H} \mathbf{~ N M R}\left(500 \mathrm{MHz}, \mathrm{CDCl}_{3}, 298 \mathrm{~K}\right): \delta_{\mathrm{H}}$ 7.64-7.54 (m, 3H), 7.52-7.45 (m, 1H), 7.44-7.36 (m, 4H), 7.36-7.31 (m, 1H), 7.30-7.23 (m, 2H), 7.01-6.94 (m, 2H), 5.07 (s, 2H), 2.09 (s, 3H) ppm; ${ }^{19} \mathbf{F}\left\{{ }^{1} \mathbf{H}\right\}$ NMR (376 MHz, $\mathrm{CDCl}_{3}, 298$ $\mathrm{K}): \delta_{\mathrm{F}}-62.6 \mathrm{ppm} ;{ }^{13} \mathbf{C}\left\{{ }^{1} \mathbf{H}\right\} \mathbf{N M R}\left(125 \mathrm{MHz}, \mathrm{CDCl}_{3}, 298 \mathrm{~K}\right): \delta_{\mathrm{C}} 158.8,143.0,136.7,132.6$, $131.5(\mathrm{q}, J=32.2 \mathrm{~Hz}), 130.4(\mathrm{q}, J=1.3 \mathrm{~Hz}), 129.6,128.3,128.0,127.6,126.3,125.0(\mathrm{q}, J=3.7$ Hz), $123.2(\mathrm{q}, J=3.8 \mathrm{~Hz}), 123.7(\mathrm{q}, J=271.2 \mathrm{~Hz}), 123.0,115.4,70.3,45.6,28.4$ ppm; HRMS $\mathrm{m} / z$ (DART): calcd for $\mathrm{C}_{23} \mathrm{H}_{19} \mathrm{NOF}_{3}(\mathrm{M}+\mathrm{H}): 382.1413$; found: 382.1408 .<smiles>CCCCOc1ccc(C(C)(C)c2cccc(Cl)c2)cc1</smiles> 
2-(4-(Benzyloxy)phenyl)-2-(3-chlorophenyl)propanenitrile (2k): Prepared on 0.30-mmol scale using 2-(3-chlorophenyl)-2-methylmalononitrile (S17) (0.10 g, $0.54 \mathrm{mmol}, 1.8$ equiv) and 1(benzyloxy)-4-iodobenzene (S29) (93 mg, $0.30 \mathrm{mmol}, 1.0$ equiv). Arylation was performed using 1.8 equiv $\alpha$-anion and $\mathrm{PhMe} / \mathrm{THF}(8: 1)$. The crude residue was purified by flash column chromatography (gradient of $20-80 \% \mathrm{PhMe} /$ hexanes) to yield the product as a colourless oil (82 mg, $0.236 \mathrm{mmol}, 79 \%) .{ }^{1} \mathbf{H}$ NMR $\left(500 \mathrm{MHz}, \mathrm{CDCl}_{3}, 298 \mathrm{~K}\right): \delta_{\mathrm{H}} 7.45-7.37$ (m, 4H), 7.37$7.31(\mathrm{~m}, 2 \mathrm{H}), 7.31-7.24(\mathrm{~m}, 5 \mathrm{H}), 6.99-6.94(\mathrm{~m}, 2 \mathrm{H}), 5.07(\mathrm{~s}, 2 \mathrm{H}), 2.05(\mathrm{~s}, 3 \mathrm{H}) \mathrm{ppm} ;{ }^{13} \mathbf{C}\left\{{ }^{1} \mathbf{H}\right\}$ NMR (125 MHz, $\left.\mathrm{CDCl}_{3}, 298 \mathrm{~K}\right): \delta_{\mathrm{C}} 158.7,143.8,136.7,135.0,132.8,130.3,128.8,128.3$, 128.3, 128.0, 127.6, 126.9, 125.0, 123.1, 115.4, 70.3, 45.5, 28.3 ppm; HRMS m/z (DART): calcd for $\mathrm{C}_{22} \mathrm{H}_{19} \mathrm{NOCl}(\mathrm{M}+\mathrm{H})$ : 348.1150; found: 348.1155 .<smiles>Cc1ccc(C(C)(C#N)c2cccc(Cl)c2)cc1</smiles>

2-(3-Chlorophenyl)-2-(p-tolyl)propanenitrile (2l): Prepared on 0.30-mmol scale using 2-(3chlorophenyl)-2-methylmalononitrile (S17) (0.10 g, $0.54 \mathrm{mmol}, 1.8$ equiv) and 4-iodotoluene (65 $\mathrm{mg}, 0.30 \mathrm{mmol}, 1.0$ equiv). Arylation was performed using 1.8 equiv $\alpha$-anion and $\mathrm{PhMe} / \mathrm{THF}$ (6:1). The crude residue was purified by flash column chromatography (gradient of 30-70\% $\mathrm{PhMe} /$ hexanes) to yield the product as a colourless oil (51 mg, 0.199, 66\%). ${ }^{1} \mathbf{H}$ NMR (500 $\left.\mathrm{MHz}, \mathrm{CDCl}_{3}, 298 \mathrm{~K}\right): \delta_{\mathrm{H}} 7.35-7.34(\mathrm{~m}, 1 \mathrm{H}), 7.30-7.27(\mathrm{~m}, 3 \mathrm{H}), 7.27-7.25(\mathrm{~m}, 1 \mathrm{H}), 7.25-7.23$ $(\mathrm{m}, 1 \mathrm{H}), 7.20-7.16(\mathrm{~m}, 2 \mathrm{H}), 2.35(\mathrm{~s}, 3 \mathrm{H}), 2.06(\mathrm{~s}, 3 \mathrm{H}) \mathrm{ppm} ;{ }^{13} \mathbf{C}\left\{{ }^{1} \mathbf{H}\right\} \mathbf{~ N M R}\left(125 \mathrm{MHz}, \mathrm{CDCl}_{3}\right.$, $298 \mathrm{~K}): \delta_{\mathrm{C}} 143.7,138.2$, 137.6, 135.0, 130.3, 129.8, 128.3, 126.9, 126.6, 125.1, 123.1, 45.8, 28.2, 21.1 ppm; HRMS m/z (DART): calcd for $\mathrm{C}_{16} \mathrm{H}_{18} \mathrm{~N}_{2} \mathrm{Cl}\left(\mathrm{M}+\mathrm{NH}_{4}\right)$ : 273.1153; found: 273.1153 .<smiles>CC(C)(c1ccc(N2CCCC2)nc1)c1cccc(Cl)c1</smiles>

2-(3-Chlorophenyl)-2-(6-(pyrrolidin-1-yl)pyridin-3-yl)propanenitrile (2m): Prepared on 0.30-mmol scale using 2-(3-chlorophenyl)-2-methylmalononitrile (S17) (0.10 g, 0.54 mmol, 1.8 equiv) and 5-iodo-2-(pyrrolidin-1-yl)pyridine (S35) $(82 \mathrm{mg}, 0.30 \mathrm{mmol}, 1.0$ equiv). Arylation was performed using 1.8 equiv $\alpha$-anion and PhMe/THF (6:1). The crude residue was purified by flash column chromatography (gradient of $0-40 \%$ acetone/hexanes) to yield the product as a yellow oil (87 mg, $0.266 \mathrm{mmol}, 89 \%) .{ }^{1} \mathbf{H} \mathbf{~ N M R}\left(400 \mathrm{MHz}, \mathrm{CDCl}_{3}, 298 \mathrm{~K}\right): \delta_{\mathrm{H}} 8.14$ (dd, $J=2.7$, $0.8 \mathrm{~Hz}, 1 \mathrm{H}), 7.37-7.33(\mathrm{~m}, 2 \mathrm{H}), 7.32-7.26(\mathrm{~m}, 3 \mathrm{H}), 6.34(\mathrm{dd}, J=8.9,0.8 \mathrm{~Hz}, 1 \mathrm{H}), 3.48-3.42(\mathrm{~m}$, 4H), 2.05-1.99 (m, 7H) ppm; ${ }^{13} \mathbf{C}\left\{{ }^{1} \mathbf{H}\right\}$ NMR (125 MHz, $\left.\mathrm{CDCl}_{3}, 298 \mathrm{~K}\right)$ : $\delta_{\mathrm{C}} 156.8,146.1,143.7$, 136.0, 135.0, 130.3, 128.3, 126.8, 124.8, 122.9, 122.8, 106.8, 46.9, 43.9, 28.0, 25.7 ppm; HRMS $m / z$ (DART): calcd fro $\mathrm{C}_{18} \mathrm{H}_{19} \mathrm{ClN}_{3}(\mathrm{M}+\mathrm{H})$ : 312.1262; found: 312.1268 .<smiles>COc1cccc(C(C)(C)c2ccc(N(C)C)cc2)c1</smiles>

2-(4-(Dimethylamino)phenyl)-2-(3-methoxyphenyl)propanenitrile (2n): Prepared on 0.20mmol scale using 2-(3-methoxyphenyl)-2-methylmalononitrile (S21) (67 mg, $0.36 \mathrm{mmol}, 1.8$ equiv) and 4-iodo- $N, N$-dimethylaniline (S33) (49 mg, $0.20 \mathrm{mmol}, 1.0$ equiv). Arylation was 
performed using $\alpha$-anion (1.8 equiv) and PhMe/THF (6:1). The crude residue was purified by flash column chromatography (5-30\% $\mathrm{PhMe} /$ hexanes) to yield the product as a colourless oil (30 mg, $0.108 \mathrm{mmol}, 54 \%) .{ }^{1} \mathbf{H}$ NMR (500 MHz, $\left.\mathrm{CDCl}_{3}, 298 \mathrm{~K}\right): \delta_{\mathrm{H}} 7.28-7.24(\mathrm{~m}, 1 \mathrm{H}), 7.24-$ $7.19(\mathrm{~m}, 2 \mathrm{H}), 6.99-6.95(\mathrm{~m}, 1 \mathrm{H}), 6.93-6.91(\mathrm{~m}, 1 \mathrm{H}), 6.84-6.79(\mathrm{~m}, 1 \mathrm{H}), 6.70-6.65(\mathrm{~m}, 2 \mathrm{H})$, $3.78(\mathrm{~s}, 3 \mathrm{H}), 2.95(\mathrm{~s}, 6 \mathrm{H}), 2.04(\mathrm{~s}, 3 \mathrm{H}) \mathrm{ppm} ;{ }^{13} \mathbf{C}\left\{{ }^{1} \mathbf{H}\right\} \mathbf{N M R}\left(125 \mathrm{MHz}, \mathrm{CDCl}_{3}, 298 \mathrm{~K}\right): \delta_{\mathrm{C}} 159.9$, 150.0, 143.9, 129.9, 128.5, 127.5, 124.0, 119.0, 113.0, 112.8, 112.5, 55.4, 45.5, 40.5, 28.4 ppm; HRMS $m / z$ (DART): calcd for $\mathrm{C}_{18} \mathrm{H}_{21} \mathrm{~N}_{2} \mathrm{O}(\mathrm{M}+\mathrm{H}): 281.1648$; found: 281.1650 .<smiles>COc1ccc(C(C)(C)c2cccc(OC)c2)cc1</smiles>

2-(3-Methoxyphenyl)-2-(4-methoxyphenyl)propanenitrile (2o): The product was prepared on 0.20-mmol scale using 2-(3-methoxyphenyl)-2-methylmalononitrile (S21) (67 mg, $0.36 \mathrm{mmol}$, 1.8 equiv) and 4-iodoanisole (47 mg, $0.20 \mathrm{mmol}, 1.0$ equiv). Arylation was performed using $\alpha$ anion (1.8 equiv) and $\mathrm{PhMe} / \mathrm{THF}(6: 1)$. The crude residue was purified by flash column chromatography $(100 \% \mathrm{PhMe})$ to yield the product as a colourless oil $(35 \mathrm{mg}, 0.131 \mathrm{mmol}$, 66\%). ${ }^{1} \mathbf{H}$ NMR $\left(500 \mathrm{MHz}, \mathrm{CDCl}_{3}, 298 \mathrm{~K}\right): \delta_{\mathrm{H}} 7.32-7.24(\mathrm{~m}, 3 \mathrm{H}), 6.98-6.94(\mathrm{~m}, 1 \mathrm{H}), 6.91-6.86$ $(\mathrm{m}, 3 \mathrm{H}), 6.85-6.81(\mathrm{~m}, 1 \mathrm{H}), 3.80(\mathrm{~s}, 3 \mathrm{H}), 3.79(\mathrm{~s}, 3 \mathrm{H}), 2.05(\mathrm{~s}, 3 \mathrm{H}) \mathrm{ppm} ;{ }^{13} \mathbf{C}\left\{{ }^{1} \mathbf{H}\right\}$ NMR $(125$ $\left.\mathrm{MHz}, \mathrm{CDCl}_{3}, 298 \mathrm{~K}\right): \delta_{\mathrm{C}} 160.0,159.3,143.4,133.3,130.0,128.0,123.7,119.0,114.3,113.1$, 112.9, 55.5, 55.4, 45.6, 28.4 ppm; HRMS m/z (DART): calcd for $\mathrm{C}_{17} \mathrm{H}_{21} \mathrm{H}_{2} \mathrm{O}_{2}\left(\mathrm{M}+\mathrm{NH}_{4}\right)$ : 285.1598; found: 285.1596 .<smiles>CC(C)(c1ccc(Cl)cc1)c1ccc(N2CCCC2)nc1</smiles>

2-(4-Chlorophenyl)-2-(6-(pyrrolidin-1-yl)pyridin-3-yl)propanenitrile (2p): The product was prepared on 0.30-mmol scale using 2-(4-chlorophenyl)-2-methylmalononitrile (S23) (0.10 mg, $0.54 \mathrm{mmol}, 1.8$ equiv) and 5-iodo-2-(pyrrolidin-1-yl)pyridine (S35) $(82 \mathrm{mg}, 0.30 \mathrm{mmol}$, 1.0 equiv). Arylation was performed using 1.8 equiv $\alpha$-anion and $\mathrm{PhMe} / \mathrm{THF}$ (6:1). The crude residue was purified by flash column chromatography (gradient of $0-40 \%$ acetone/hexanes) to yield the product as a yellow oil (70 mg, $0.224 \mathrm{mmol}, 75 \%) .{ }^{1} \mathbf{H} \mathbf{N M R}\left(500 \mathrm{MHz}, \mathrm{CDCl}_{3}, 298\right.$ $\mathrm{K}): \delta_{\mathrm{H}} 8.14(\mathrm{dd}, J=0.7,0.2 \mathrm{~Hz}, 1 \mathrm{H}), 7.36-7.29(\mathrm{~m}, 5 \mathrm{H}), 6.35-6.30(\mathrm{~m}, 1 \mathrm{H}), 3.51-3.38(\mathrm{~m}, 4 \mathrm{H})$, 2.09-1.95 (m, 7H) ppm; ${ }^{13} \mathbf{C}\left\{{ }^{1} \mathbf{H}\right\}$ NMR $\left(125 \mathrm{MHz}, \mathrm{CDCl}_{3}, 298 \mathrm{~K}\right): \delta_{\mathrm{C}} 156.8,146.0,140.3$, 136.0, 136.0, 134.0, 129.2, 128.0, 123.0, 106.8, 46.9, 43.6, 28.0, 25.7 ppm; HRMS $m / z$ (DART): calcd for $\mathrm{C}_{18} \mathrm{H}_{19} \mathrm{~N}_{3} \mathrm{Cl}(\mathrm{M}+\mathrm{H}): 312.1262$; found: 312.1259 .<smiles>N#Cc1ccc(N2CCCC2)nc1</smiles>

2-(4-Fluorophenyl)-2-(6-(pyrrolidin-1-yl)pyridin-3-yl)propanenitrile (2q): Prepared on 0.30mmol scale using 2-(4-fluorophenyl)-2-methylmalononitrile (S28) (94 mg, 0.54 mmol, 1.8 equiv) and 5-iodo-2-(pyrrolidin-1-yl)pyridine (S35) (82 mg, $0.30 \mathrm{mmol}, 1.0$ equiv). Arylation was performed using 1.8 equiv $\alpha$-anion and PhMe/THF (6:1). The crude residue was purified by flash column chromatography (gradient of $0-40 \%$ acetone/hexanes) to yield the 
product as a colourless oil (59 mg, $0.200 \mathrm{mmol}, 67 \%) .{ }^{1} \mathbf{H} \mathbf{~ N M R}\left(500 \mathrm{MHz}, \mathrm{CDCl}_{3}, 298 \mathrm{~K}\right): \delta_{\mathrm{H}}$ $8.13(\mathrm{dd}, J=0.7,0.2 \mathrm{~Hz}, 1 \mathrm{H}), 7.38-7.33(\mathrm{~m}, 3 \mathrm{H}), 7.07-7.01(\mathrm{~m}, 2 \mathrm{H}), 6.34(\mathrm{dd}, J=2.2,0.2 \mathrm{~Hz}$, 1H), 3.48-3.41 (m, 4H), 2.07-1.97 (m, 7H) ppm; ${ }^{19} \mathbf{F}\left\{{ }^{1} \mathbf{H}\right\}$ NMR $\left(376 \mathrm{MHz}, \mathrm{CDCl}_{3}, 298 \mathrm{~K}\right): \delta_{\mathrm{F}}$ -114.4 ppm; ${ }^{13} \mathbf{C}\left\{{ }^{1} \mathbf{H}\right\}$ NMR $\left(125 \mathrm{MHz}, \mathrm{CDCl}_{3}, 298 \mathrm{~K}\right): \delta_{\mathrm{C}} 162.3(\mathrm{~d}, J=246.4 \mathrm{~Hz}), 156.8,153.3$, 146.0, 137.5 (d, $J=3.4 \mathrm{~Hz}), 136.0(\mathrm{~d}, J=1.1 \mathrm{~Hz}), 128.4$ (d, $J=8.2 \mathrm{~Hz}), 123.3$ (d, $J=14.0 \mathrm{~Hz})$, 115.9 (d, $J=21.6 \mathrm{~Hz}$ ), 106.7 (d, $J=1.1 \mathrm{~Hz}), 46.9$, 43.5, 28.3, $25.7 \mathrm{ppm}$; HRMS $\mathrm{m} / z$ (DART): calcd for $\mathrm{C}_{18} \mathrm{H}_{19} \mathrm{~N}_{3} \mathrm{~F}(\mathrm{M}+\mathrm{H})$ : 296.1558; found: 296.1560 .

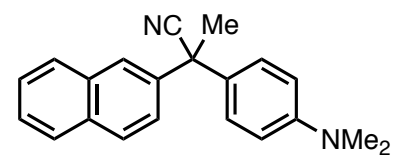

2-(4-(Dimethylamino)phenyl)-2-(naphthalen-2-yl)propanenitrile (2r): Prepared on 0.30mmol scale using 2-methyl-2-(naphthalen-2-yl)malononitrile (S25) (0.11 g, 0.54 mmol, 1.8 equiv) and 4-iodo- $N, N$-dimethylaniline (S33) (49 mg, $0.20 \mathrm{mmol}, 1.0$ equiv). Arylation was performed using $\alpha$-anion (1.8 equiv) and PhMe/THF (6:1). The crude residue was purified by flash column chromatography (gradient of $40-100 \% \mathrm{PhMe} /$ hexanes) to yield the product as a colourless oil (62 mg, $0.206 \mathrm{mmol}, 69 \%) .{ }^{1} \mathbf{H} \mathbf{~ N M R}\left(500 \mathrm{MHz}, \mathrm{CDCl}_{3}, 298 \mathrm{~K}\right): \delta_{\mathrm{H}} 7.98-7.95(\mathrm{~m}$, $1 \mathrm{H}), 7.88-7.77(\mathrm{~m}, 3 \mathrm{H}), 7.54-7.48(\mathrm{~m}, 2 \mathrm{H}), 7.35(\mathrm{dd}, J=8.7,2.1 \mathrm{~Hz}, 1 \mathrm{H}), 7.27-7.23(\mathrm{~m}, 2 \mathrm{H})$, 6.71-6.67 (m, 2H), 2.95 (s, 6H), $2.14(\mathrm{~s}, 3 \mathrm{H}) \mathrm{ppm} ;{ }^{13} \mathbf{C}\left\{{ }^{1} \mathbf{H}\right\}$ NMR $\left(125 \mathrm{MHz}, \mathrm{CDCl}_{3}, 298 \mathrm{~K}\right): \delta_{\mathrm{C}}$ $150.1,139.5,133.2,132.7,128.9,128.4,128.4,127.7,127.7,126.7,126.6,125.0,124.9,124.0$, 112.5, 45.6, 40.5, 28.2 ppm; HRMS $m / z$ (DART): calcd fro $\mathrm{C}_{21} \mathrm{H}_{21} \mathrm{~N}_{2}(\mathrm{M}+\mathrm{H})$ : 301.1699 ; found: 301.1701 .<smiles>Cc1ccc(C(C)(C)c2ccc(C(C)(C)C)cc2)cc1C</smiles>

2-(4-(tert-Butyl)phenyl)-2-(3,4-dimethylphenyl)propanenitrile (2s): Prepared on 0.30-mmol scale using 2-(4-(tert-butyl)phenyl)-2-methylmalononitrile (S27) (0.11 g, 0.54 mmol, 1.8 equiv) and 1-iodo-3,4-dimethylbenzene ( $43 \mu \mathrm{L}, 0.30 \mathrm{mmol}, 1.8$ equiv). Arylation was performed using $\alpha$-anion (1.8 equiv) and PhMe/THF (6:1). The crude residue was purified by flash column chromatography (gradient of $20-80 \% \mathrm{PhMe} /$ hexanes) to yield the product as a colourless oil (35 mg, 0.120 mmol, 40\%). ${ }^{1} \mathbf{H}$ NMR (500 MHz, $\left.\mathrm{CDCl}_{3}, 298 \mathrm{~K}\right): \delta_{\mathrm{H}} 7.37-7.34(\mathrm{~m}, 2 \mathrm{H}), 7.31-7.27$ $(\mathrm{m}, 2 \mathrm{H}), 7.19-7.17(\mathrm{~m}, 1 \mathrm{H}), 7.13-7.07(\mathrm{~m}, 2 \mathrm{H}), 2.26(\mathrm{~s}, 3 \mathrm{H}), 2.25(\mathrm{~s}, 3 \mathrm{H}), 2.05(\mathrm{~s}, 3 \mathrm{H}), 1.31(\mathrm{~s}$, 9H) ppm; ${ }^{13} \mathbf{C}\left\{{ }^{1} \mathbf{H}\right\}$ NMR $\left(125 \mathrm{MHz}, \mathrm{CDCl}_{3}, 298 \mathrm{~K}\right): \delta_{\mathrm{C}} 150.8,138.9,138.6,137.2,136.4,130.1$, 130.1, 128.0, 126.3, 125.8, 124.0, 45.6, 34.6, 31.4, 28.3, 20.1, 19.5 ppm; HRMS $\mathrm{m} / z$ (DART): calcd for $\mathrm{C}_{21} \mathrm{H}_{29} \mathrm{~N}_{2}\left(\mathrm{M}+\mathrm{NH}_{4}\right)$ : 309.2325; found: 309.2331 .<smiles>CN(C)c1ccc(C(Br)(Br)c2cccc(Cl)c2)cc1</smiles>

2-(3-Chlorophenyl)-2-(4-(dimethylamino)phenyl)hexanenitrile (2t): Prepared on 0.30-mmol scale using 2-butyl-2-(3-chlorophenyl)malononitrile (S19) (0.13 g, $0.54 \mathrm{mmol}, 1.8$ equiv) and 4iodo- $N, N$-dimethylaniline (S33) (49 mg, $0.20 \mathrm{mmol}, 1.0$ equiv). Arylation was performed using $\alpha$-anion (1.8 equiv) and PhMe/THF (6:1). The crude residue was purified by flash column chromatography (gradient of $40-100 \% \mathrm{PhMe} /$ hexanes) to yield the product as a colourless oil 
(60 mg, $0.183 \mathrm{mmol}, 61 \%) .{ }^{1} \mathbf{H}$ NMR $\left(500 \mathrm{MHz}, \mathrm{CDCl}_{3}, 298 \mathrm{~K}\right): \delta_{\mathrm{H}} 7.36-7.33(\mathrm{~m}, 1 \mathrm{H}), 7.30-$ $7.23(\mathrm{~m}, 3 \mathrm{H}), 7.22-7.17(\mathrm{~m}, 2 \mathrm{H}), 6.71-6.65(\mathrm{~m}, 2 \mathrm{H}), 2.95(\mathrm{~s}, 6 \mathrm{H}), 2.37-2.21(\mathrm{~m}, 2 \mathrm{H}), 1.48-1.31$ (m, 4H), 0.90 (t, $J=7.0 \mathrm{~Hz}, 3 \mathrm{H}) \mathrm{ppm} ;{ }^{13} \mathbf{C}\left\{{ }^{1} \mathbf{H}\right\} \mathbf{N M R}\left(125 \mathrm{MHz}, \mathrm{CDCl}_{3}, 298 \mathrm{~K}\right): \delta_{\mathrm{C}} 150.0$, 143.6, 134.8, 130.0, 127.9, 127.7, 127.1, 126.8, 125.2, 122.6, 112.5, 50.9, 40.5, 39.6, 27.9, 22.8, 14.0 ppm; HRMS m/z (DART): calcd for $\mathrm{C}_{20} \mathrm{H}_{24} \mathrm{~N}_{2} \mathrm{Cl}(\mathrm{M}+\mathrm{H}): 327.1623$; found: 327.1626 .<smiles>CNc1ccc(C(Br)(Br)c2cccc(Cl)c2)cc1</smiles>

2-(3-Chlorophenyl)-2-(4-(dimethylamino)phenyl)-3-phenylpropanenitrile (2u): Prepared on 0.30-mmol scale using 2-benzyl-2-(3-chlorophenyl)malononitrile (S18) (0.14 g, $0.54 \mathrm{mmol}, 1.8$ equiv) and 4-iodo- $N, N$-dimethylaniline (S33) $(49 \mathrm{mg}, 0.20 \mathrm{mmol}, 1.0$ equiv). Arylation was performed using 1.8 equiv $\alpha$-anion and PhMe/THF (6:1). The crude residue was purified by flash column chromatography (gradient of $0-70 \% \mathrm{PhMe} /$ hexanes) to yield the product as an off-white solid (63 mg, $0.174 \mathrm{mmol}, 58 \%)$. ${ }^{1} \mathbf{H}$ NMR (500 MHz, $\left.\mathrm{CDCl}_{3}, 298 \mathrm{~K}\right): \delta_{\mathrm{H}} 7.28-7.15(\mathrm{~m}, 9 \mathrm{H})$, 6.93-6.89 (m, 2H), 6.70-6.65 (m, 2H), $3.65(\mathrm{~d}, J=13.1 \mathrm{~Hz}, 1 \mathrm{H}), 3.53$ (d, $J=13.1 \mathrm{~Hz}, 1 \mathrm{H}), 2.97$ (s, 6H) ppm; ${ }^{13} \mathbf{C}\left\{{ }^{1} \mathbf{H}\right\}$ NMR $\left(125 \mathrm{MHz}, \mathrm{CDCl}_{3}, 298 \mathrm{~K}\right): \delta_{\mathrm{C}} 150.2,142.9,134.8,134.6,130.7$, $129.8,128.2,128.1,128.0,127.6,127.4,126.6,125.9,121.9,112.4,52.1,45.5,40.5 \mathrm{ppm}$; HRMS $m / z$ (DART): calcd for $\mathrm{C}_{23} \mathrm{H}_{22} \mathrm{~N}_{2} \mathrm{Cl}(\mathrm{M}+\mathrm{H}): 361.1466$; found: 361.1467 .<smiles>CCC(C#N)(c1ccc(N(C)C)cc1)c1cccc(C(F)(F)F)c1</smiles>

2-(4-(Dimethylamino)phenyl)-2-(3-(trifluoromethyl)phenyl)butanenitrile (2v): Prepared on 0.30-mmol scale using 2-ethyl-2-(3-(trifluoromethyl)phenyl)malononitrile (S14) (100 mg, $0.42 \mathrm{mmol}, 1.4$ equiv) and 4-iodo- $N, N$-dimethylaniline (S33) (49 mg, $0.20 \mathrm{mmol}, 1.0$ equiv). Arylation was performed using $\alpha$-anion (1.4 equiv) and PhMe/THF (6:1). The crude residue was purified by flash column chromatography (gradient of 0-20\% EtOAc/hexanes) to yield the product as a colourless oil $(74 \mathrm{mg}, 0.223 \mathrm{mmol}, 74 \%) .{ }^{1} \mathbf{H} \mathbf{~ N M R}\left(400 \mathrm{MHz}, \mathrm{CDCl}_{3}, 298 \mathrm{~K}\right)$ : $\delta_{\mathrm{H}}$ 7.67-7.41 (m, 4H), 7.23-7.15 (m, 2H), 6.72-6.65 (m, 2H), $2.96(\mathrm{~s}, 6 \mathrm{H}), 2.50-2.29(\mathrm{~m}, 2 \mathrm{H}), 1.05$ $(\mathrm{t}, J=7.3 \mathrm{~Hz}, 3 \mathrm{H}) \mathrm{ppm} ;{ }^{19} \mathbf{F}\left\{{ }^{1} \mathbf{H}\right\} \mathbf{N M R}\left(376 \mathrm{MHz}, \mathrm{CDCl}_{3}, 298 \mathrm{~K}\right): \delta_{\mathrm{F}}-62.5 \mathrm{ppm} ;{ }^{13} \mathbf{C}\left\{{ }^{1} \mathbf{H}\right\} \mathbf{N M R}$ $\left(125 \mathrm{MHz}, \mathrm{CDCl}_{3}, 298 \mathrm{~K}\right): \delta_{\mathrm{C}} 150.1,142.4,131.2(\mathrm{q}, J=32.2 \mathrm{~Hz}), 130.7(\mathrm{q}, J=1.3 \mathrm{~Hz}), 129.4$, 127.8, 126.4, 124.7 (q, $J=3.7 \mathrm{~Hz}), 124.0(\mathrm{q}, J=271.2 \mathrm{~Hz}), 123.5(\mathrm{q}, J=3.8 \mathrm{~Hz}), 122.2,112.5$, 51.8, 40.4, 33.1, 10.2 ppm; HRMS $m / z$ (DART): calcd for $\mathrm{C}_{19} \mathrm{H}_{20} \mathrm{~N}_{2} \mathrm{~F}_{3}(\mathrm{M}+\mathrm{H}): 333.1573$; found: 333.1575 .<smiles>CCCC(C#N)(c1ccc(N(C)C)cc1)c1cccc(C(F)(F)F)c1</smiles>

2-(4-(Dimethylamino)phenyl)-3-methyl-2-(3-(trifluoromethyl)phenyl)butanenitrile (2w): Prepared on 0.30-mmol scale using 2-isopropyl-2-(3-(trifluoromethyl)phenyl)malononitrile (S15) (0.11 g, $0.42 \mathrm{mmol}, 1.4$ equiv) and 4-iodo- $N, N$-dimethylaniline (S33) $(49 \mathrm{mg}, 0.20 \mathrm{mmol}$, 1.0 equiv). Arylation was performed using $\alpha$-anion (1.4 equiv) and $\mathrm{PhMe} / \mathrm{THF}(6: 1)$. The crude 
residue was purified by flash column chromatography (gradient of 0-20\% EtOAc/hexanes) to yield the product as a colourless oil $(23 \mathrm{mg}, 0.066 \mathrm{mmol}, 22 \%) .{ }^{1} \mathbf{H} \mathbf{~ N M R}\left(500 \mathrm{MHz}, \mathrm{CDCl}_{3}\right.$, $298 \mathrm{~K}): \delta_{\mathrm{H}} 7.73-7.65(\mathrm{~m}, 2 \mathrm{H}), 7.52-7.41(\mathrm{~m}, 2 \mathrm{H}), 7.33-7.27(\mathrm{~m}, 2 \mathrm{H}), 6.70-6.64(\mathrm{~m}, 2 \mathrm{H}), 2.94$ (s, 6H), 2.86 (sept, $J=2.0 \mathrm{~Hz}, 1 \mathrm{H}), 1.12(\mathrm{~d}, J=6.6 \mathrm{~Hz}, 3 \mathrm{H}), 1.02$ (d, $J=6.6 \mathrm{~Hz}, 3 \mathrm{H}) \mathrm{ppm}$; ${ }^{19} \mathbf{F}\left\{{ }^{1} \mathbf{H}\right\}$ NMR $\left(376 \mathrm{MHz}, \mathrm{CDCl}_{3}, 298 \mathrm{~K}\right): \delta_{\mathrm{F}}-62.6 \mathrm{ppm} ;{ }^{13} \mathbf{C}\left\{{ }^{1} \mathbf{H}\right\} \mathbf{N M R}\left(125 \mathrm{MHz}, \mathrm{CDCl}_{3}, 298\right.$ $\mathrm{K}): \delta_{\mathrm{C}} 149.9,142.1,131.2(\mathrm{q}, J=32.2 \mathrm{~Hz}), 130.3(\mathrm{q}, J=1.3 \mathrm{~Hz}), 129.4,127.6,126.3,124.4(\mathrm{q}, J$ $=3.7 \mathrm{~Hz}), 124.0(\mathrm{q}, J=271.1 \mathrm{~Hz}), 123.3(\mathrm{q}, J=3.9 \mathrm{~Hz}), 120.8,112.5,58.3,40.4,35.1,19.2$, $19.1 \mathrm{ppm}$; HRMS m/z (DART): calcd for $\mathrm{C}_{20} \mathrm{H}_{22} \mathrm{~N}_{2} \mathrm{~F}_{3}(\mathrm{M}+\mathrm{H}): 347.1730$; found: 347.1737 .

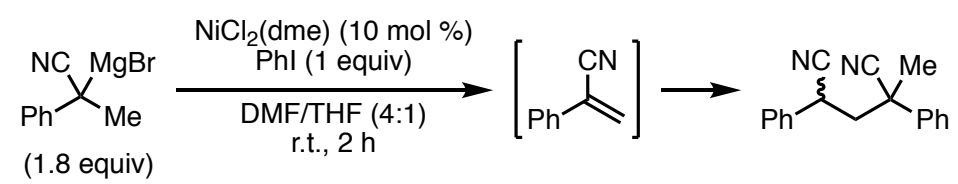

4-Cyano-2-methyl-2,4-diphenylbutanenitrile (mixture of syn and anti) (5): The product was prepared on 0.40-mmol scale according to General Procedure A using 2-methyl-2phenylmalononitrile (4a) $(0.11 \mathrm{~g}, 0.72 \mathrm{mmol}, 1.8$ equiv), iodobenzene ( $45 \mu \mathrm{L}, 0.40 \mathrm{mmol}, 1.0$ equiv), and no ligand. The arylation was performed in DMF/THF (2:1) instead of PhMe/THF. The crude material was purified using flash column chromatography (gradient of $0-30 \%$ EtOAc/hexanes) to yield the product as a colourless oil, which was an inseparable mixture of diastereomers (54 mg, $0.207 \mathrm{mmol}, 52 \%) .{ }^{1} \mathbf{H} \mathbf{~ N M R}\left(500 \mathrm{MHz}, \mathrm{CDCl}_{3}, 298 \mathrm{~K}\right)$ : $\delta_{\mathrm{H}} 7.57-7.20$ (m, 20H), 3.82 (dd, $J=9.9,4.0 \mathrm{~Hz}, 1 \mathrm{H}), 3.73$ (dd, $J=8.6,5.3 \mathrm{~Hz}, 1 \mathrm{H}), 2.72-2.62$ (m, 2H), 2.48 $(\mathrm{dd}, J=14.4,5.3 \mathrm{~Hz}, 1 \mathrm{H}), 2.32(\mathrm{dd}, J=14.5,3.9 \mathrm{~Hz}, 1 \mathrm{H}), 1.90(\mathrm{~s}, 3 \mathrm{H}), 1.79$ (s, 3H) ppm; ${ }^{13} \mathbf{C}\left\{{ }^{1} \mathbf{H}\right\}$ NMR $\left(125 \mathrm{MHz}, \mathrm{CDCl}_{3}, 298 \mathrm{~K}\right): \delta_{\mathrm{C}} 138.6,137.1,135.3,135.0,129.5,129.4,129.3$, $129.3,128.9,128.7,128.5,128.5,127.5,127.2$, 125.8, 125.3, 121.8, 121.8, 120.0, 119.4, 47.6, 47.4, 42.1, 41.9, 34.3, 34.1, 28.3, 27.4 ppm; HRMS $m / z$ (DART): calcd for $\mathrm{C}_{18} \mathrm{H}_{20} \mathrm{~N}_{3}\left(\mathrm{M}+\mathrm{NH}_{4}\right)$ : 278.1652; found: 278.1645 . 


\section{E. Preparation of malononitrile starting materials}

General Procedure B: Preparation of malononitrile starting materials

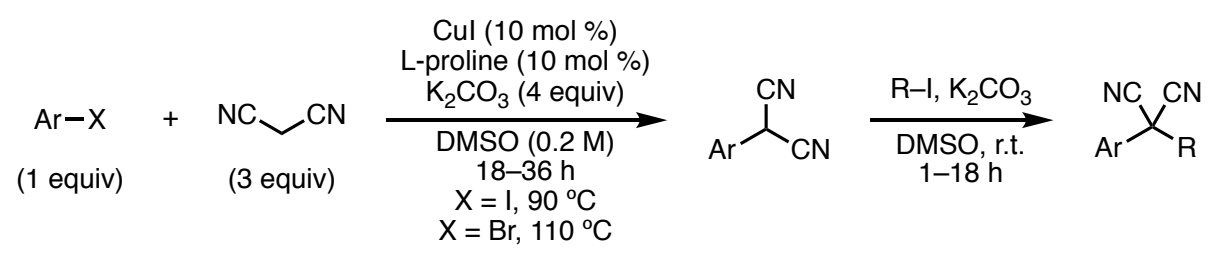

Step 1: An appropriate-sized round-bottom flask with a stir bar was flame-dried and cooled under vacuum. To the flask were added potassium carbonate (4.0 equiv), copper(I) iodide (10 mol \%), L-proline (10 mol \%), malononitrile (3.0 equiv), and aryl halide (if a solid) (1.0 equiv). The flask was evacuated and backfilled with $\mathrm{N}_{2}(\times 3)$ and DMSO $(0.20 \mathrm{M})$ was added. The flask was again evacuated and backfilled with $\mathrm{N}_{2}(\times 3)$, sealed, and put under a balloon of $\mathrm{N}_{2}$. Aryl halide (if an oil) was added (1.0 equiv). The reaction was stirred at the appropriate temperature $\left(90^{\circ} \mathrm{C}\right.$ for aryl iodides, $110^{\circ} \mathrm{C}$ for aryl bromides) until full conversion of aryl halide was achieved, as determined by TLC $(18-36 \mathrm{~h})$. The reaction was cooled to $0^{\circ} \mathrm{C}$ and opened to air, and $1.0 \mathrm{M} \mathrm{HCl}$ was added to bring the solution to $\mathrm{pH} 2-3$. The solution was extracted with EtOAc $(\times 3)$, and the organic fractions were combined, washed with $\mathrm{H}_{2} \mathrm{O}(\times 3)$ and brine $(\times 3)$, dried over $\mathrm{MgSO}_{4}$, filtered, and concentrated. The crude residue was purified by flash column chromatography to yield the desired arylmalononitrile.

Step 2: To an appropriate-sized round-bottom flask with a stir bar were added 2arylmalononitrile (1.0 equiv), potassium carbonate (1.2-1.5 equiv), DMSO (1.0 M), and alkyl iodide (1.1-1.5 equiv), and the reaction was stirred at r.t. until full conversion was achieved, as determined by TLC $(1-18 \mathrm{~h})$. The reaction was quenched with $\mathrm{H}_{2} \mathrm{O}$ and extracted with EtOAc $(\times 3)$, and the organic fractions were combined, washed with brine $(\times 3)$, dried over $\mathrm{MgSO}_{4}$, and concentrated. The crude residue was purified by flash column chromatography (gradient of 0 $20 \% \mathrm{EtOAc} /$ hexanes) to yield the disubstituted malononitrile.

${ }_{\mathrm{Ph}}^{\mathrm{CN}}$

2-Phenylmalononitrile (S11): Prepared according to General Procedure B (Step 1) using copper(I) iodide (1.9 g, $10 \mathrm{mmol}, 20 \mathrm{~mol} \%$ ), L-proline (1.2 g, $10 \mathrm{mmol}, 20 \mathrm{~mol} \%)$, potassium carbonate ( $28 \mathrm{~g}, 200 \mathrm{mmol}, 4$ equiv), malononitrile ( $9.9 \mathrm{~g}, 150 \mathrm{mmol}, 3.0$ equiv), DMSO (250 $\mathrm{mL}, 0.20 \mathrm{M})$, and iodobenzene $\left(5.6 \mathrm{~mL}, 50 \mathrm{mmol}, 1.0\right.$ equiv). The reaction was stirred at $90^{\circ} \mathrm{C}$ for $18 \mathrm{~h}$. The crude residue was purified by flash column chromatography (gradient of 10-20\% EtOAc/hexanes) to yield the product as an off-white solid (6.2 g, $44 \mathrm{mmol}, 88 \%)$. Analytical data: ${ }^{24}{ }^{1} \mathbf{H}$ NMR $\left(400 \mathrm{MHz}, \mathrm{CDCl}_{3}, 298 \mathrm{~K}\right): \delta_{\mathrm{H}} 7.62-7.42(\mathrm{~m}, 5 \mathrm{H}), 5.07(\mathrm{~s}, 1 \mathrm{H}) \mathrm{ppm} ;{ }^{13} \mathbf{C}\left\{{ }^{1} \mathbf{H}\right\}$ NMR (100 MHz, $\left.\mathrm{CDCl}_{3}, 298 \mathrm{~K}\right): \delta_{\mathrm{C}} 130.4,130.2,127.2,126.2,111.7,28.1 \mathrm{ppm} ; \mathbf{R}_{\mathbf{f}}(9: 1$ hexanes/EtOAc; $\left.\mathrm{KMnO}_{4} / \mathrm{PMA}\right): 0.16$.<smiles>CC(N)(N)C(C)(N)N</smiles>

2-Methyl-2-phenylmalononitrile (4a): Prepared according to General Procedure B (Step 2) using 2-phenylmalononitrile (6.0 g, $42 \mathrm{mmol}, 1.0$ equiv), DMSO (40 mL, 1.0 M) iodomethane 
(3.1 mL, $50 \mathrm{mmol}, 1.2$ equiv), and potassium carbonate (12 g, $84 \mathrm{mmol}, 2.0$ equiv). The reaction was stirred at r.t. for $2 \mathrm{~h}$. The crude residue was purified by flash column chromatography (gradient of 5-20\% EtOAc/hexanes) to yield the product as a colourless oil (6.4 g, $41 \mathrm{mmol}$, 98\%). Analytical data: ${ }^{25}{ }^{1} \mathbf{H}$ NMR (400 MHz, $\left.\mathrm{CDCl}_{3}, 298 \mathrm{~K}\right): \delta_{\mathrm{H}} 7.64-7.42(\mathrm{~m}, 5 \mathrm{H}), 2.13(\mathrm{~s}, 3 \mathrm{H})$ ppm; ${ }^{13} \mathbf{C}\left\{{ }^{1} \mathbf{H}\right\}$ NMR $\left(100 \mathrm{MHz}, \mathrm{CDCl}_{3}, 298 \mathrm{~K}\right): \delta_{\mathrm{C}} 113.1,130.0,129.8,129.3,115.7,36.4,29.5$ ppm; $\mathbf{R}_{\mathbf{f}}(9: 1$ hexanes/EtOAc; UV): 0.39.<smiles>N#CC(C#N)c1cccc(C(F)(F)F)c1</smiles>

2-(3-(Trifluoromethyl)phenyl)malononitrile (S12): Prepared according to General Procedure B (Step 1) using 3-iodobenzotrifluoride (1.4 mL, $10 \mathrm{mmol}, 1.0$ equiv), malononitrile $(2.0 \mathrm{~g}, 30$ mmol, 3.0 equiv), potassium carbonate $(5.5 \mathrm{~g}, 40 \mathrm{mmol}, 4.0$ equiv), copper(I) iodide ( $0.19 \mathrm{~g}, 1.0$ mmol, 0.10 equiv), L-proline ( $0.12 \mathrm{~g}, 1.0 \mathrm{mmol}, 0.10$ equiv), and DMSO (50 mL, $0.20 \mathrm{M})$. The reaction was stirred at $90{ }^{\circ} \mathrm{C}$ for $18 \mathrm{~h}$. The crude residue was purified by flash column chromatography (gradient of 10-40\% EtOAc/hexanes) to yield the product as an off-white solid (1.4 g, 6.6 mmol, 66\%). Analytical data: $\left.{ }^{26}{ }^{1} \mathbf{H ~ N M R ~ ( 4 0 0 ~ M H z , ~} \mathrm{CDCl}_{3}, 298 \mathrm{~K}\right): \delta_{\mathrm{H}} 7.83-7.72$ $(\mathrm{m}, 3 \mathrm{H}), 7.69(\mathrm{t}, J=7.7 \mathrm{~Hz}, 1 \mathrm{H}), 5.15(\mathrm{~s}, 1 \mathrm{H}) \mathrm{ppm} ;{ }^{19} \mathbf{F}\left\{{ }^{\mathbf{1}} \mathbf{H}\right\} \mathbf{N M R}\left(376 \mathrm{MHz}, \mathrm{CDCl}_{3}, 298 \mathrm{~K}\right): \delta_{\mathrm{F}}$ -62.9 ppm; ${ }^{13} \mathbf{C}\left\{{ }^{1} \mathbf{H}\right\}$ NMR $\left(125 \mathrm{MHz}, \mathrm{CDCl}_{3}, 298 \mathrm{~K}\right): \delta_{\mathrm{C}} 132.8(\mathrm{q}, J=33.3 \mathrm{~Hz}), 131.0,130.7$ $(\mathrm{q}, J=1.2 \mathrm{~Hz}), 127.6(\mathrm{q}, J=3.7 \mathrm{~Hz}), 127.5,124.4(\mathrm{q}, J=3.8 \mathrm{~Hz}), 123.3(\mathrm{q}, J=271.3 \mathrm{~Hz})$, $111.2,28.1 \mathrm{ppm}$.<smiles>CC(C)(C#N)c1cccc(C(F)(F)F)c1</smiles>

2-Methyl-2-(3-(trifluoromethyl)phenyl)malononitrile (S13): Prepared according to General Procedure B (Step 2) using 2-(3-(trifluoromethyl)phenyl)malononitrile (1.0 g, $5.0 \mathrm{mmol}$, 1.0 equiv), iodomethane $(0.34 \mathrm{~mL}, 5.5 \mathrm{mmol}, 1.1$ equiv), potassium carbonate $(0.83 \mathrm{~g}, 6.0 \mathrm{mmol}$, 1.2 equiv), and DMSO $(10 \mathrm{~mL}, 0.50 \mathrm{M})$. The reaction was stirred at r.t. for $1 \mathrm{~h}$. The crude residue was purified by flash column chromatography (gradient of 0-30\% EtOAc/hexanes) to yield the product as a colourless oil $(1.07 \mathrm{~g}, 4.8 \mathrm{mmol}, 96 \%) .{ }^{\mathbf{1}} \mathbf{H} \mathbf{N M R}\left(400 \mathrm{MHz}, \mathrm{CDCl}_{3}, 298\right.$ $\mathrm{K}): \delta_{\mathrm{H}} 7.87-7.79(\mathrm{~m}, 2 \mathrm{H}), 7.79-7.73(\mathrm{~m}, 1 \mathrm{H}), 7.71-7.64(\mathrm{~m}, 1 \mathrm{H}), 2.16(\mathrm{~s}, 3 \mathrm{H}) \mathrm{ppm} ;{ }^{19} \mathbf{F}\left\{{ }^{1} \mathbf{H}\right\}$ NMR (376 MHz, $\left.\mathrm{CDCl}_{3}, 298 \mathrm{~K}\right): \delta_{\mathrm{F}}-62.8 \mathrm{ppm} ;{ }^{13} \mathbf{C}\left\{{ }^{1} \mathbf{H}\right\} \mathbf{N M R}\left(100 \mathrm{MHz}, \mathrm{CDCl}_{3}, 298 \mathrm{~K}\right): \delta_{\mathrm{C}}$ $134.5,132.7(\mathrm{q}, J=32.9 \mathrm{~Hz}), 131.0,129.0(\mathrm{q}, J=1.4 \mathrm{~Hz}), 127.2(\mathrm{q}, J=3.7 \mathrm{~Hz}), 123.4(\mathrm{q}, J=$ $271.0 \mathrm{~Hz}$ ), 122.5 (q, $J=3.8 \mathrm{~Hz}), 115.1,36.4,29.5 \mathrm{ppm}$; HRMS $m / z$ (DART): calcd for $\mathrm{C}_{11} \mathrm{H}_{11} \mathrm{~N}_{3} \mathrm{~F}_{3}\left(\mathrm{M}+\mathrm{NH}_{4}\right): 242.0900$; found: 242.0900 .<smiles>CCC(C)(C#N)c1cccc(C(F)(F)F)c1</smiles>

2-Ethyl-2-(3-(trifluoromethyl)phenyl)malononitrile (S14): Prepared according to General Procedure B (Step 2) using 2-(3-(trifluoromethyl)phenyl)malononitrile (1.05 g, $5.0 \mathrm{mmol}, 1.0$ equiv), iodoethane (0.48 mL, $6.0 \mathrm{mmol}, 1.2$ equiv), potassium carbonate (1.0 g, $7.5 \mathrm{mmol}, 1.5$ 
equiv), and DMSO (10 mL, $0.50 \mathrm{M})$. The reaction was stirred at r.t. for $16 \mathrm{~h}$. The crude residue was purified by flash column chromatography (gradient of 0-20\% EtOAc/hexanes) to yield the product as a colourless oil (0.90 g, $3.8 \mathrm{mmol}, 76 \%) .{ }^{1} \mathbf{H}$ NMR $\left(500 \mathrm{MHz}, \mathrm{CDCl}_{3}, 298 \mathrm{~K}\right)$ : $\delta_{\mathrm{H}}$ $7.83-7.73(\mathrm{~m}, 3 \mathrm{H}), 7.70-7.63(\mathrm{~m}, 1 \mathrm{H}), 2.32(\mathrm{q}, J=7.4 \mathrm{~Hz}, 2 \mathrm{H}), 1.27(\mathrm{t}, J=7.3 \mathrm{~Hz}, 3 \mathrm{H}) \mathrm{ppm}$; ${ }^{19} \mathbf{F}\left\{{ }^{1} \mathbf{H}\right\}$ NMR $\left(376 \mathrm{MHz}, \mathrm{CDCl}_{3}, 298 \mathrm{~K}\right): \delta_{\mathrm{F}}-62.8 \mathrm{ppm} ;{ }^{13} \mathbf{C}\left\{{ }^{1} \mathbf{H}\right\} \mathbf{N M R}\left(125 \mathrm{MHz}, \mathrm{CDCl}_{3}, 298\right.$ $\mathrm{K}): \delta_{\mathrm{C}} 133.4,132.5(\mathrm{q}, J=33.0 \mathrm{~Hz}), 130.6,129.4(\mathrm{q}, J=1.3 \mathrm{~Hz}), 127.1(\mathrm{q}, J=3.7 \mathrm{~Hz}), 123.4(\mathrm{q}$, $J=127.4 \mathrm{~Hz}), 122.9(\mathrm{q}, J=3.7 \mathrm{~Hz}), 114.4,43.2,36.8,10.2 \mathrm{ppm}$; HRMS $m / z$ (DART): calcd for $\mathrm{C}_{12} \mathrm{H}_{13} \mathrm{~N}_{3} \mathrm{~F}_{3}\left(\mathrm{M}+\mathrm{NH}_{4}\right)$ : 256.1056; found: 256.1060 .<smiles>CC(C)C(C)(C#N)c1cccc(C(F)(F)F)c1</smiles>

2-Isopropyl-2-(3-(trifluoromethyl)phenyl)malononitrile (S15): Prepared according to General Procedure B (Step 2) using 2-(3-(trifluoromethyl)phenyl)malononitrile (1.05 g, 5.0 mmol, 1.0 equiv), 2-iodopropane $(0.60 \mathrm{~mL}, 6.0 \mathrm{mmol}, 1.2$ equiv), potassium carbonate $(1.0 \mathrm{~g}, 7.5 \mathrm{mmol}$, 1.5 equiv), and DMSO $(10 \mathrm{~mL}, 0.50 \mathrm{M})$. The reaction was stirred at r.t. for $16 \mathrm{~h}$. The crude residue was purified by flash column chromatography (gradient of 0-20\% EtOAc/hexanes) to yield the product as a colourless oil (0.55 g, $2.2 \mathrm{mmol}, 44 \%)$. ${ }^{\mathbf{1}} \mathbf{H} \mathbf{~ N M R}\left(500 \mathrm{MHz}, \mathrm{CDCl}_{3}, 298\right.$ $\mathrm{K}): \delta_{\mathrm{H}} 7.81-7.72(\mathrm{~m}, 3 \mathrm{H}), 7.69-7.63(\mathrm{~m}, 1 \mathrm{H}), 2.47(\mathrm{sept}, J=6.7 \mathrm{~Hz}, 1 \mathrm{H}), 1.19(\mathrm{~d}, J=6.8 \mathrm{~Hz}$, $6 \mathrm{H}) \mathrm{ppm} ;{ }^{19} \mathbf{F}\left\{{ }^{1} \mathbf{H}\right\}$ NMR $\left(376 \mathrm{MHz}, \mathrm{CDCl}_{3}, 298 \mathrm{~K}\right): \delta_{\mathrm{F}}-62.8 \mathrm{ppm} ;{ }^{13} \mathbf{C}\left\{{ }^{\mathbf{1}} \mathbf{H}\right\} \mathbf{N M R}(125 \mathrm{MHz}$, $\left.\mathrm{CDCl}_{3}, 298 \mathrm{~K}\right): \delta_{\mathrm{C}} 132.8,132.4(\mathrm{q}, J=33.0 \mathrm{~Hz}), 130.4,130.0(\mathrm{q}, J=1.3 \mathrm{~Hz}), 127.1(\mathrm{q}, J=3.6$ $\mathrm{Hz}), 123.4(\mathrm{q}, J=271.4 \mathrm{~Hz}), 124.4$ (q, $J=3.7 \mathrm{~Hz}), 114.0,48.7,40.7,18.3 \mathrm{ppm} ; \mathbf{H R M S ~} \mathrm{m} / z$ (DART): calcd for $\mathrm{C}_{13} \mathrm{H}_{11} \mathrm{~N}_{2} \mathrm{~F}_{3}(\mathrm{M}+$ ): 252.0869 ; found: 252.0864 .<smiles>N#CC(C#N)c1cccc(Cl)c1</smiles>

2-(3-Chlorophenyl)malononitrile (S16): Prepared according to General Procedure B (Step 1) using 3-chloroiodobenzene (1.2 mL, $10 \mathrm{mmol}, 1.0$ equiv), malononitrile (2.0 g, $30 \mathrm{mmol}, 3.0$ equiv), potassium carbonate $(5.5 \mathrm{~g}, 40 \mathrm{mmol}, 4.0$ equiv $)$, copper(I) iodide $(0.19 \mathrm{~g}, 1.0 \mathrm{mmol}$, 0.10 equiv), L-proline ( $0.12 \mathrm{~g}, 1.0 \mathrm{mmol}, 0.10$ equiv), and DMSO (50 mL, $0.20 \mathrm{M})$. The reaction was stirred at $90{ }^{\circ} \mathrm{C}$ for $18 \mathrm{~h}$. The crude residue was purified by flash column chromatography (gradient of 10-40\% EtOAc/hexanes) to yield the product as an off-white solid (1.4 g, $7.7 \mathrm{mmol}$, 77\%). Analytical data: ${ }^{26}{ }^{1} \mathbf{H}$ NMR (500 MHz, $\left.\mathrm{CDCl}_{3}, 298 \mathrm{~K}\right): \delta_{\mathrm{H}} 7.54-7.40(\mathrm{~m}, 4 \mathrm{H}), 5.06(\mathrm{~s}, 1 \mathrm{H})$ ppm; ${ }^{13} \mathbf{C}\left\{{ }^{1} \mathbf{H}\right\}$ NMR $\left(125 \mathrm{MHz}, \mathrm{CDCl}_{3}, 298 \mathrm{~K}\right): \delta_{\mathrm{C}} 136.1,131.3,130.8,127.8,127.5,125.4$, 111.1, 27.6 ppm.<smiles>CC(C)(C#N)c1cccc(Cl)c1</smiles>

2-(3-Chlorophenyl)-2-methylmalononitrile (S17): Prepared according to General Procedure B (Step 2) using 2-(3-chlorophenyl)malononitrile ( $0.88 \mathrm{~g}, 5.0 \mathrm{mmol}, 1.0$ equiv), iodomethane (0.34 $\mathrm{mL}, 5.5 \mathrm{mmol}, 1.1$ equiv), potassium carbonate ( $0.83 \mathrm{~g}, 6.0 \mathrm{mmol}, 1.2$ equiv), and DMSO (10 
$\mathrm{mL}, 0.50 \mathrm{M}$ ). The reaction was stirred at r.t. for $1 \mathrm{~h}$. The crude residue was purified by flash column chromatography (gradient of $0-30 \%$ EtOAc/hexanes) to yield the product as a colourless oil (0.92 g, 4.8 mmol, 96\%). ${ }^{1} \mathbf{H}$ NMR (500 MHz, $\left.\mathrm{CDCl}_{3}, 298 \mathrm{~K}\right)$ : $\delta_{\mathrm{H}} 7.60-7.57$ (m, 1H), 7.51$7.44(\mathrm{~m}, 3 \mathrm{H}), 2.12$ (s, 3H) ppm; ${ }^{13} \mathbf{C}\left\{{ }^{1} \mathbf{H}\right\}$ NMR $\left(125 \mathrm{MHz}, \mathrm{CDCl}_{3}, 298 \mathrm{~K}\right): \delta_{\mathrm{C}} 136.1,135.0$, $131.3,130.5,125.8,123.7,115.2,36.2,29.5 \mathrm{ppm}$.<smiles>N#CC(C#N)(Cc1ccccc1)c1cccc(Cl)c1</smiles>

2-Benzyl-2-(3-chlorophenyl)malononitrile (S18): Prepared according to General Procedure B (Step 2) using 2-(3-chlorophenyl)malononitrile (0.62 g, $3.5 \mathrm{mmol}, 1.0$ equiv), benzyl bromide ( $0.50 \mathrm{~mL}, 4.2 \mathrm{mmol}, 1.2$ equiv), potassium carbonate $(0.73 \mathrm{~g}, 5.3 \mathrm{mmol}, 1.5$ equiv), and DMSO $(10 \mathrm{~mL}, 0.35 \mathrm{M})$. The reaction was stirred at r.t. for $1 \mathrm{~h}$. The crude residue was purified by flash column chromatography (gradient of 5-20\% EtOAc/hexanes) to yield the product as a white solid (0.41 g, $1.5 \mathrm{mmol}, 43 \%) .{ }^{1} \mathbf{H}$ NMR (500 MHz, CDCl $\left.3,298 \mathrm{~K}\right): \delta_{\mathrm{H}} 7.48-7.30(\mathrm{~m}, 7 \mathrm{H})$, 7.17-7.13 (m, 2H), 3.45 (s, 2H) ppm; ${ }^{13} \mathbf{C}\left\{{ }^{1} \mathbf{H}\right\}$ NMR (125 MHz, $\left.\mathrm{CDCl}_{3}, 298 \mathrm{~K}\right): \delta_{\mathrm{C}} 135.8,133.5$, $131.2,130.9,130.6,130.5,129.2,128.9,126.6,124.5,114.3,48.5,43.8 \mathrm{ppm} ;$ HRMS m/z (DART): calcd for $\mathrm{C}_{16} \mathrm{H}_{15} \mathrm{~N}_{3} \mathrm{Cl}\left(\mathrm{M}+\mathrm{NH}_{4}\right)$ : 284.0949; found: 284.0951 ; m.p.: $94-95{ }^{\circ} \mathrm{C}$.<smiles>CCCCC(C)(C#N)c1cccc(Cl)c1</smiles>

2-Butyl-2-(3-chlorophenyl)malononitrile (S19): Prepared according to General Procedure B (Step 2) using 2-(3-chlorophenyl)malononitrile ( $0.53 \mathrm{~g}, 3.0 \mathrm{mmol}, 1.0$ equiv), 1-iodobutane (0.41 $\mathrm{mL}, 3.6 \mathrm{mmol}, 1.2$ equiv), potassium carbonate ( $0.62 \mathrm{~g}, 4.5 \mathrm{mmol}, 1.5 \mathrm{equiv})$, and DMSO $(10 \mathrm{~mL}, 0.30 \mathrm{M})$. The reaction was stirred at r.t. for $16 \mathrm{~h}$. The crude residue was purified by flash column chromatography (gradient of $0-20 \%$ EtOAc/hexanes) to yield the product as a colourless oil $(0.45 \mathrm{~g}, 1.9 \mathrm{mmol}, 63 \%) .{ }^{1} \mathbf{H}$ NMR $\left(500 \mathrm{MHz}, \mathrm{CDCl}_{3}, 298 \mathrm{~K}\right): \delta_{\mathrm{H}} 7.56(\mathrm{td}, J=1.7,1.0 \mathrm{~Hz}$, $1 \mathrm{H}), 7.48-7.43(\mathrm{~m}, 3 \mathrm{H}), 2.23-2.18(\mathrm{~m}, 2 \mathrm{H}), 1.65-1.56(\mathrm{~m}, 2 \mathrm{H}), 1.41(\mathrm{tq}, J=7.6,7.6 \mathrm{~Hz}, 2 \mathrm{H})$, $0.94(\mathrm{t}, J=7.4 \mathrm{~Hz}, 3 \mathrm{H}) \mathrm{ppm} ;{ }^{13} \mathbf{C}\left\{{ }^{1} \mathbf{H}\right\} \mathbf{N M R}\left(125 \mathrm{MHz}, \mathrm{CDCl}_{3}, 298 \mathrm{~K}\right): \delta_{\mathrm{C}} 136.0,134.3,131.1$, 130.4, 126.2 , 124.1, 114.7, 42.5, 42.1, 27.7, 21.9, 13.7 ppm; HRMS $m / z$ (DART): calcd for $\mathrm{C}_{13} \mathrm{H}_{17} \mathrm{~N}_{3} \mathrm{Cl}\left(\mathrm{M}+\mathrm{NH}_{4}\right)$ : 250.1106; found: 250.1108 .<smiles>COc1cccc(C(C#N)C#N)c1</smiles>

2-(3-Methoxyphenyl)malononitrile (S20): Prepared according to General Procedure B (Step 1) using 3-bromoanisole (1.9 mL, $15 \mathrm{mmol}, 1.0$ equiv), malononitrile (3.0 g, $45 \mathrm{mmol}, 3.0$ equiv), copper(I) iodide ( $0.29 \mathrm{~g}, 1.5 \mathrm{mmol}, 0.10$ equiv), L-proline $(0.17 \mathrm{~g}, 1.5 \mathrm{mmol}, 0.10$ equiv), potassium carbonate $(8.3 \mathrm{~g}, 60 \mathrm{mmol}, 4.0$ equiv), and DMSO $(40 \mathrm{~mL}, 0.38 \mathrm{M})$. The reaction was stirred at $110^{\circ} \mathrm{C}$ for $36 \mathrm{~h}$. The crude residue was purified by flash column chromatography (gradient of 10-30\% EtOAc/hexanes) to yield the product as a white solid (1.0 g, $5.8 \mathrm{mmol}$, 39\%). Analytical data: ${ }^{27} \mathbf{H}$ NMR (400 MHz, $\left.\mathrm{CDCl}_{3}, 298 \mathrm{~K}\right): \delta_{\mathrm{H}} 7.44-7.37$ (m, 1H), 7.10-7.04 
$(\mathrm{m}, 1 \mathrm{H}), 7.03-6.98(\mathrm{~m}, 2 \mathrm{H}), 5.03(\mathrm{~s}, 1 \mathrm{H}), 3.86(\mathrm{~s}, 3 \mathrm{H}) \mathrm{ppm} ;{ }^{13} \mathbf{C}\left\{{ }^{1} \mathbf{H}\right\} \mathbf{N M R}\left(100 \mathrm{MHz}, \mathrm{CDCl}_{3}\right.$, $298 \mathrm{~K}): \delta_{\mathrm{C}} 160.8,131.3,127.5,119.4,116.1,113.0,111.8,55.7,28.2 \mathrm{ppm}$.<smiles>COc1cccc(C(C)(C)C#N)c1</smiles>

2-(3-Methoxyphenyl)-2-methylmalononitrile (S21): Prepared according to General Procedure B (Step 2) using 2-(3-methoxyphenyl)malononitrile ( $0.86 \mathrm{~g}, 5.0 \mathrm{mmol}, 1.0$ equiv), iodomethane ( $0.37 \mathrm{~mL}, 6.0 \mathrm{mmol}, 1.2$ equiv), potassium phosphate ( $1.0 \mathrm{~g}, 7.5 \mathrm{mmol}, 1.5$ equiv), and DMSO $(10 \mathrm{~mL}, 0.50 \mathrm{M})$. The reaction was stirred at r.t. for $16 \mathrm{~h}$. The crude residue was purified by flash column chromatography (gradient of 5-30\% EtOAc/hexanes) to yield the product as a colourless oil (0.86 g, $4.6 \mathrm{mmol}, 92 \%)$. ${ }^{1} \mathbf{H}$ NMR (400 MHz, $\left.\mathrm{CDCl}_{3}, 298 \mathrm{~K}\right): \delta_{\mathrm{H}} 7.41(\mathrm{t}, J=8.0 \mathrm{~Hz}, 1 \mathrm{H})$, 7.16 (ddd, $J=7.8,2.1,0.9 \mathrm{~Hz}, 1 \mathrm{H}), 7.09$ (t, $J=2.2 \mathrm{~Hz}, 1 \mathrm{H}), 6.98$ (ddd, $J=8.3,2.4,0.9 \mathrm{~Hz}, 1 \mathrm{H}$ ), $3.86(\mathrm{~s}, 3 \mathrm{H}), 2.11(\mathrm{~s}, 3 \mathrm{H}) \mathrm{ppm} ;{ }^{13} \mathbf{C}\left\{{ }^{1} \mathbf{H}\right\}$ NMR $\left(100 \mathrm{MHz}, \mathrm{CDCl}_{3}, 298 \mathrm{~K}\right): \delta_{\mathrm{C}} 160.7,134.6$, 131.1, 117.5, 115.8, 115.4, 111.6, 55.7, 36.5, 29.5 ppm; HRMS $m / z$ (DART): calcd for $\mathrm{C}_{11} \mathrm{H}_{14} \mathrm{~N}_{3} \mathrm{O}\left(\mathrm{M}+\mathrm{NH}_{4}\right): 204.1131$; found: 204.1136 .<smiles>N#CC(C#N)c1ccc(Cl)cc1</smiles>

2-(4-Chlorophenyl)malononitrile (S22): Prepared according to General Procedure B (Step 1) using 4-chloroiodobenzene ( $2.9 \mathrm{~g}, 12 \mathrm{mmol}, 1.0$ equiv), malononitrile ( $2.4 \mathrm{~g}, 36 \mathrm{mmol}, 3.0$ equiv), copper(I) iodide ( $0.23 \mathrm{~g}, 1.2 \mathrm{mmol}, 0.10$ equiv), L-proline ( $0.14 \mathrm{~g}, 1.2 \mathrm{mmol}, 0.10$ equiv), potassium carbonate $(6.6 \mathrm{~g}, 48 \mathrm{mmol}, 4.0$ equiv), and DMSO (50 $\mathrm{mL}, 0.24 \mathrm{M})$. The reaction was stirred at $90{ }^{\circ} \mathrm{C}$ for $24 \mathrm{~h}$. The crude residue was purified by flash column chromatography (gradient of 10-40\% EtOAc/hexanes) to yield the product as a white solid (1.2 g, $6.8 \mathrm{mmol}$, 57\%). Analytical data: ${ }^{28}{ }^{1} \mathbf{H}$ NMR $\left(500 \mathrm{MHz}, \mathrm{CDCl}_{3}, 298 \mathrm{~K}\right): \delta_{\mathrm{H}} 7.52-7.43(\mathrm{~m}, 4 \mathrm{H}), 5.06(\mathrm{~s}, 1 \mathrm{H})$ ppm; ${ }^{13} \mathbf{C}\left\{{ }^{1} \mathbf{H}\right\}$ NMR $\left(125 \mathrm{MHz}, \mathrm{CDCl}_{3}, 298 \mathrm{~K}\right): \delta_{\mathrm{C}} 137.0,130.4,128.7,124.8,111.5,27.7 \mathrm{ppm}$.<smiles>CC(C)(C#N)c1ccc(Cl)cc1</smiles>

2-(4-Chlorophenyl)-2-methylmalononitrile (S23): Prepared according to General Procedure B (Step 2) using 2-(4-chlorophenyl)malononitrile ( $0.71 \mathrm{~g}, 4.0 \mathrm{mmol}, 1.0$ equiv), iodomethane (0.31 $\mathrm{mL}, 4.8 \mathrm{mmol}, 1.2$ equiv), potassium carbonate ( $0.83 \mathrm{~g}, 6.0 \mathrm{mmol}, 1.5$ equiv), and DMSO (10 $\mathrm{mL}, 0.40 \mathrm{M})$. The crude residue was purified by flash column chromatography (gradient of 5$30 \% \mathrm{EtOAc} / \mathrm{hexanes})$ to yield the product as a white solid $(0.62 \mathrm{~g}, 3.3 \mathrm{mmol}, 83 \%) .{ }^{\mathbf{1}} \mathbf{H} \mathbf{~ N M R}$ $\left(500 \mathrm{MHz}, \mathrm{CDCl}_{3}, 298 \mathrm{~K}\right): \delta_{\mathrm{H}} 7.55-7.51(\mathrm{~m}, 2 \mathrm{H}), 7.50-7.46(\mathrm{~m}, 2 \mathrm{H}), 2.11(\mathrm{~s}, 3 \mathrm{H}) \mathrm{ppm} ;{ }^{13} \mathbf{C}\left\{{ }^{1} \mathbf{H}\right\}$ NMR (125 MHz, $\left.\mathrm{CDCl}_{3}, 298 \mathrm{~K}\right): \delta_{\mathrm{C}} 136.5,131.8,130.2,126.9,115.4,36.1,29.5$ ppm; HRMS $m / z$ (DART): calcd for $\mathrm{C}_{10} \mathrm{H}_{11} \mathrm{~N}_{3} \mathrm{Cl}\left(\mathrm{M}+\mathrm{NH}_{4}\right)$ : 208.0636; found: 208.0642 ; m.p.: $56-57{ }^{\circ} \mathrm{C}$. 
<smiles>N#CC(C#N)c1ccc2ccccc2c1</smiles>

2-(Naphthalen-2-yl)malononitrile (S24): Prepared according to General Procedure B (Step 1) using 2-bromonaphthalene ( $3.1 \mathrm{~g}, 15 \mathrm{mmol}, 1.0$ equiv), malononitrile (3.0 g, $45 \mathrm{mmol}, 3.0$ equiv), copper(I) iodide ( $0.29 \mathrm{~g}, 1.5 \mathrm{mmol}, 0.10$ equiv), L-proline ( $0.17 \mathrm{~g}, 1.5 \mathrm{mmol}, 0.10 \mathrm{equiv})$, potassium carbonate $(8.3 \mathrm{~g}, 60 \mathrm{mmol}, 4.0$ equiv), and DMSO $(75 \mathrm{~mL}, 0.20 \mathrm{M})$. The reaction was stirred at $110^{\circ} \mathrm{C}$ for $18 \mathrm{~h}$. The crude material was purified by flash column chromatography to yield the product as a brown solid, which was inseparable from malononitrile (ca. $7.8 \mathrm{mmol}$ isolated, 52\%). The material was used in the next step without further purification and the characterization data was consistent with literature. ${ }^{27}$<smiles>CC(C)(C#N)c1ccc2ccccc2c1</smiles>

2-Methyl-2-(naphthalen-2-yl)malononitrile (S25): Prepared according to General Procedure B (Step 2) using 2-(naphthalen-2-yl)malononitrile (1.6 g, $7.8 \mathrm{mmol}, 1.0$ equiv), iodomethane (1.5 $\mathrm{mL}, 23 \mathrm{mmol}, 3.0$ equiv), potassium carbonate (3.2 g, $23 \mathrm{mmol}, 3.0$ equiv), and DMSO (16 mL, $0.50 \mathrm{M}$ ). The reaction was stirred at r.t. for $16 \mathrm{~h}$. The crude residue was purified by flash column chromatography (gradient of 10-30\% EtOAc/hexanes) to yield the product as a white solid $(0.76$ g, $4.0 \mathrm{mmol}, 51 \%) .{ }^{1} \mathbf{H}$ NMR $\left(400 \mathrm{MHz}, \mathrm{CDCl}_{3}, 298 \mathrm{~K}\right): \delta_{\mathrm{H}} 8.09(\mathrm{~d}, J=2.2 \mathrm{~Hz}, 1 \mathrm{H}), 7.99(\mathrm{~d}, J=$ 8.7 Hz, 1H), 7.95-7.87 (m, 2H), 7.63-7.57 (m, 3H), $2.20(\mathrm{~s}, 3 \mathrm{H}) \mathrm{ppm} ;{ }^{13} \mathbf{C}\left\{{ }^{1} \mathbf{H}\right\} \mathbf{~ N M R}(100 \mathrm{MHz}$, $\left.\mathrm{CDCl}_{3}, 298 \mathrm{~K}\right): 133.5,133.1,130.4,130.2$, 128.5, 127.9, 127.9, 127.7, 125.2, 122.0, 115.8, 36.8, $29.5 \mathrm{ppm}$; HRMS $m / z$ (DART): calcd for $\mathrm{C}_{14} \mathrm{H}_{14} \mathrm{~N}_{3}\left(\mathrm{M}+\mathrm{NH}_{4}\right)$ : 224.1182; found: 224.1181 ;

m.p.: $36-37^{\circ} \mathrm{C}$.<smiles>CC(C)(C)c1ccc(C(C#N)C#N)cc1</smiles>

2-(4-(tert-Butyl)phenyl)malononitrile (S26): Prepared according to General Procedure B (Step 1) using malononitrile (3.0 g, $45 \mathrm{mmol}, 3.0$ equiv), potassium carbonate ( $8.3 \mathrm{~g}, 60 \mathrm{mmol}, 4.0$ equiv), copper(I) iodide (0.44 g, $2.3 \mathrm{mmol}, 15 \mathrm{~mol} \%)$, L-proline (0.26 g, $2.3 \mathrm{mmol}, 15 \mathrm{~mol} \%)$, DMSO (75 mL, 0.20 M), and 1-bromo-4-(tert-butyl)benzene (2.6 mL, $15 \mathrm{mmol}, 1.0$ equiv). The reaction was stirred at $110^{\circ} \mathrm{C}$ for $16 \mathrm{~h}$. The concentrate was purified by flash column chromatography (gradient of 0-20\% EtOAc/hexanes) to yield the product as a white solid (2.0 g, $10 \mathrm{mmol}, 67 \%) .{ }^{1} \mathbf{H}$ NMR $\left(400 \mathrm{MHz}, \mathrm{CDCl}_{3}, 298 \mathrm{~K}\right): \delta_{\mathrm{H}} 7.54-7.48(\mathrm{~m}, 2 \mathrm{H}), 7.46-7.40(\mathrm{~m}, 2 \mathrm{H})$, $5.03(\mathrm{~s}, 1 \mathrm{H}), 1.34(\mathrm{~s}, 9 \mathrm{H}) \mathrm{ppm} ;{ }^{13} \mathbf{C}\left\{{ }^{\mathbf{1}} \mathbf{H}\right\} \mathbf{~ N M R}\left(100 \mathrm{MHz}, \mathrm{CDCl}_{3}, 298 \mathrm{~K}\right): \delta_{\mathrm{C}} 154.0,127.2$, 127.1, 123.3, 112.0, 35.0, 31.3, 27.9 ppm; $\mathbf{R}_{\mathbf{f}}(7: 3$ hexanes/EtOAc; UV/KMnO 4$): 0.59$.<smiles>CC(C)(C)c1ccc(C(C)(C)C#N)cc1</smiles>

2-(4-(tert-Butyl)phenyl)-2-methylmalononitrile (S27): Prepared according to General Procedure B (Step 2) using 2-(4-(tert-butyl)phenyl)malononitrile (0.99 g, $5.0 \mathrm{mmol}, 1.0$ equiv), DMSO (20 mL, $0.5 \mathrm{M})$, iodomethane $(0.34 \mathrm{~mL}, 5.5 \mathrm{mmol}, 1.1$ equiv), and potassium carbonate $(0.83 \mathrm{~g}, 6.0 \mathrm{mmol}, 1.2$ equiv). The reaction was stirred at r.t. for $1 \mathrm{~h}$. The crude residue was 
purified by flash column chromatography (gradient of $0-10 \%$ EtOAc/hexanes) to yield the product as an off-white solid $(0.91 \mathrm{~g}, 4.3 \mathrm{mmol}, 86 \%) .{ }^{1} \mathbf{H} \mathbf{~ N M R}\left(400 \mathrm{MHz}, \mathrm{CDCl}_{3}, 298 \mathrm{~K}\right): \delta_{\mathrm{H}}$ 7.52-7.49 (m, 4H), 2.11 (s, 3H), 1.34 (s, 9H) ppm; ${ }^{13} \mathbf{C}\left\{{ }^{1} \mathbf{H}\right\}$ NMR (100 MHz, $\left.\mathrm{CDCl}_{3}, 298 \mathrm{~K}\right): \delta_{\mathrm{C}}$ $153.4,130.0,126.8,125.1,115.8,36.0,34.8,31.1,28.3 \mathrm{ppm} ; \mathbf{R}_{\mathbf{f}}(8: 2$ hexanes/EtOAc; $\left.\mathrm{UV} / \mathrm{KMnO}_{4}\right): 0.47$; HRMS $m / z$ (DART): calcd for $\mathrm{C}_{14} \mathrm{H}_{20} \mathrm{~N}_{3}\left(\mathrm{M}+\mathrm{NH}_{4}\right): 230.1652$; found: 230.1652 .

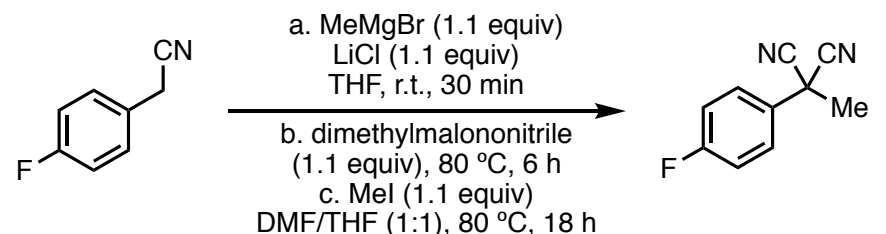

2-(4-Fluorophenyl)-2-methylmalononitrile (S28): ${ }^{29}$ To a flame-dried 16-mL threaded culture tube with a stir bar was added lithium chloride ( $0.18 \mathrm{~g}, 4.4 \mathrm{mmol}, 1.0$ equiv), and the tube was flame-dried under vacuum and cooled under $\mathrm{N}_{2}$. To the tube were sequentially added THF (4.0 mL, 1.0 M), 4-fluorobenzyl cyanide $(0.48 \mathrm{~mL}, 4.0 \mathrm{mmol}, 1.0$ equiv), and methylmagnesium bromide ( $1.5 \mathrm{~mL}$ of a $3.0 \mathrm{M}$ solution in $\mathrm{Et}_{2} \mathrm{O}, 4.4 \mathrm{mmol}, 1.1$ equiv), and the reaction was stirred at r.t. for $30 \mathrm{~min}$. The reaction tube was briefly opened to air and dimethylmalononitrile $(0.41 \mathrm{~g}$, $4.4 \mathrm{mmol}, 1.1$ equiv) was added at once. The tube was re-sealed and stirred at $80{ }^{\circ} \mathrm{C}$ for $6 \mathrm{~h}$. The solution was cooled to r.t. and diluted with DMF $(4.0 \mathrm{~mL}$, total reaction solvent $=8.0 \mathrm{~mL}$ of a 1:1 DMF/THF mixture, $0.50 \mathrm{M})$. Iodomethane $(0.27 \mathrm{~mL}, 4.4 \mathrm{mmol}, 1.1$ equiv) was added, and the reaction was stirred at $80{ }^{\circ} \mathrm{C}$ for $18 \mathrm{~h}$. The reaction was cooled to r.t. and quenched with sat. aq. $\mathrm{NH}_{4} \mathrm{Cl}$. The solution was extracted with EtOAc $(\times 3)$, and the organic fractions were combined, washed with brine $(\times 1)$, dried over $\mathrm{MgSO}_{4}$, and concentrated. The crude residue was purified by flash column chromatography (gradient of 0-30\% EtOAc/hexanes) to yield the product as a colourless oil $(0.60 \mathrm{~g}, 3.4 \mathrm{mmol}, 85 \%)$. Analytical data: ${ }^{29}{ }^{1} \mathbf{H}$ NMR $(400 \mathrm{MHz}$, $\left.\mathrm{CDCl}_{3}, 298 \mathrm{~K}\right): \delta_{\mathrm{H}} 7.62-7.54(\mathrm{~m}, 2 \mathrm{H}), 7.23-7.15(\mathrm{~m}, 2 \mathrm{H}), 2.11(\mathrm{~s}, 3 \mathrm{H}) \mathrm{ppm} ;{ }^{\mathbf{1 9}} \mathbf{F}\left\{{ }^{\mathbf{1}} \mathbf{H}\right\} \mathbf{~ N M R}(376$ $\left.\mathrm{MHz}, \mathrm{CDCl}_{3}, 298 \mathrm{~K}\right): \delta_{\mathrm{F}}-110.3 ;{ }^{13} \mathbf{C}\left\{{ }^{1} \mathbf{H}\right\} \mathbf{N M R}\left(125 \mathrm{MHz}, \mathrm{CDCl}_{3}, 298 \mathrm{~K}\right): \delta_{\mathrm{C}} 163.5(\mathrm{~d}, J=$ $250.0 \mathrm{~Hz}), 129.1(\mathrm{~d}, J=3.5 \mathrm{~Hz}), 127.6$ (d, $J=8.7 \mathrm{~Hz}), 117.1$ (d, $J=22.4 \mathrm{~Hz}), 115.6,36.0,29.6$ ppm. 


\section{F. Preparation of aryl iodide starting materials}

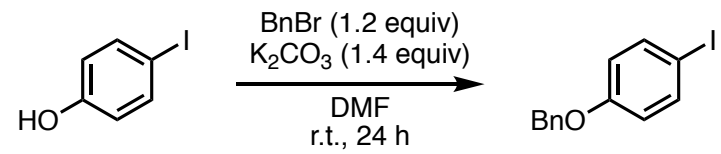

1-(Benzyloxy)-4-iodobenzene (S29): To a 50-mL flask with a stir bar were added 4-iodophenol ( $0.88 \mathrm{~g}, 4.0 \mathrm{mmol}, 1.0$ equiv), potassium carbonate $(0.77 \mathrm{~g}, 5.6 \mathrm{mmol}, 1.4$ equiv), DMF (16 mL, $0.25 \mathrm{M})$, and benzyl bromide $(0.57 \mathrm{~mL}, 4.8 \mathrm{mmol}, 1.2$ equiv $)$, and the mixture was stirred at r.t. for $24 \mathrm{~h}$. The reaction was quenched with $\mathrm{H}_{2} \mathrm{O}$ and extracted with EtOAc $(\times 3)$, and the organic fractions were combined, washed with brine $(\times 1)$, dried over $\mathrm{MgSO}_{4}$, and concentrated. The crude residue was purified by flash column chromatography (gradient of 0-10\% EtOAc/hexanes) to yield the product as a white solid $(1.0 \mathrm{~g}, 3.2 \mathrm{mmol}, 80 \%)$. Analytical data: ${ }^{30}{ }^{1} \mathbf{H}$ NMR (400 $\left.\mathrm{MHz}, \mathrm{CDCl}_{3}, 298 \mathrm{~K}\right): \delta_{\mathrm{H}} 7.60-7.52(\mathrm{~m}, 2 \mathrm{H}), 7.45-7.30(\mathrm{~m}, 5 \mathrm{H}), 6.79-6.72(\mathrm{~m}, 2 \mathrm{H}), 5.04(\mathrm{~s}, 2 \mathrm{H})$ ppm; ${ }^{13} \mathbf{C}\left\{{ }^{1} \mathbf{H}\right\}$ NMR $\left(100 \mathrm{MHz}, \mathrm{CDCl}_{3}, 298 \mathrm{~K}\right): \delta_{\mathrm{C}} 158.8,138.4,136.7,128.8,128.2,127.6$, $117.5,83.2,70.2 \mathrm{ppm}$.

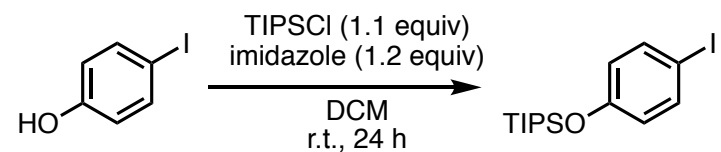

(4-Iodophenoxy)triisopropylsilane (S30): To a flame-dried 50-mL flask with a stir bar were sequentially added 4-iodophenol ( $0.88 \mathrm{~g}, 4.0 \mathrm{mmol}, 1.0$ equiv), imidazole $(0.33 \mathrm{~g}, 4.8 \mathrm{mmol}, 1.2$ equiv), DCM (16 mL, $0.25 \mathrm{M})$, and TIPSCl ( $0.94 \mathrm{~mL}, 4.4 \mathrm{mmol}, 1.1$ equiv). The reaction was stirred at r.t. for $24 \mathrm{~h}$. The solution was concentrated and the crude residue was purified by flash column chromatography (gradient of $0-5 \%$ EtOAc/hexanes) to yield the product as a colourless oil (1.5 g, 4.0 mmol, 100\%). Analytical data: $\left.{ }^{31}{ }^{1} \mathbf{H ~ N M R ~ ( 4 0 0 ~ M H z , ~ C D C l ~} 3,298 \mathrm{~K}\right): \delta_{\mathrm{H}} 7.52-$ 7.45 (m, 2H), 6.68-6.62 (m, 2H), 1.24 (hept, $J=7.0 \mathrm{~Hz}, 3 \mathrm{H}), 1.09$ (d, $J=7.0 \mathrm{~Hz}, 18 \mathrm{H}) \mathrm{ppm}$; ${ }^{13} \mathbf{C}\left\{{ }^{1} \mathbf{H}\right\} \mathbf{N M R}\left(100 \mathrm{MHz}, \mathrm{CDCl}_{3}, 298 \mathrm{~K}\right): \delta_{\mathrm{C}} 156.2,138.4,122.5,83.3,18.0,12.8 \mathrm{ppm}$.

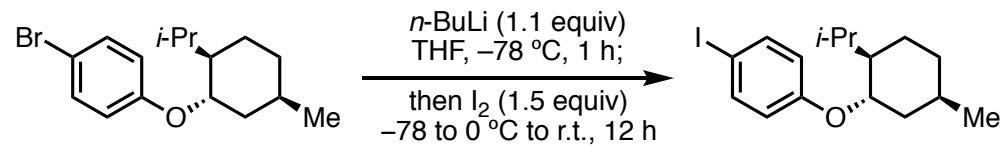

1-Iodo-4-(((1S,2R,5R)-2-isopropyl-5-methylcyclohexyl)oxy)benzene (S31): To a flame-dried 10 -mL flask with a stir bar was added 1-bromo-4-(((1S,2R,5R)-2-isopropyl-5methylcyclohexyl)oxy)benzene $(0.62 \mathrm{~g}, 2.0 \mathrm{mmol}, 1.0$ equiv). The flask was sealed with a septum, evacuated and backfilled with $\mathrm{N}_{2}(\times 3)$, and put under a balloon of $\mathrm{N}_{2}$. THF $(3.0 \mathrm{~mL}$, $0.67 \mathrm{M}$ ) was added, and the solution was cooled and stirred at $-78^{\circ} \mathrm{C}$. To the solution was added dropwise $n$-butyllithium (1.4 $\mathrm{mL}$ of a $1.6 \mathrm{M}$ solution in hexanes, $2.2 \mathrm{mmol}, 1.1$ equiv), and the solution was stirred at $-78^{\circ} \mathrm{C}$ for $1 \mathrm{~h}$. The flask was briefly opened to air, iodine $(0.76 \mathrm{~g}, 3.0$ mmol, 1.5 equiv) was added at once, and the flask was re-sealed. The solution was warmed to $0{ }^{\circ} \mathrm{C}$ and allowed to stir at that temperature until the exotherm stopped (ca. $5 \mathrm{~min}$ ), then was stirred at r.t. for another $12 \mathrm{~h}$. The reaction was quenched with sat. aq. $\mathrm{Na}_{2} \mathrm{~S}_{2} \mathrm{O}_{3}$ and extracted with EtOAc $(\times 3)$, and the organic fractions were combined, washed with brine $(\times 1)$, dried over $\mathrm{MgSO}_{4}$, and concentrated. The crude residue was purified by flash column chromatography (gradient of 0-5\% EtOAc/hexanes) to yield the product as a colourless oil $(0.62 \mathrm{~g}, 1.7 \mathrm{mmol}$, 85\%). ${ }^{1} \mathbf{H}$ NMR $\left(500 \mathrm{MHz}, \mathrm{CDCl}_{3}, 298 \mathrm{~K}\right): \delta_{\mathrm{H}} 7.54-7.50(\mathrm{~m}, 2 \mathrm{H}), 6.70-6.65(\mathrm{~m}, 2 \mathrm{H}), 3.97(\mathrm{td}, J$ $=10.6,4.2 \mathrm{~Hz}, 1 \mathrm{H}), 2.21-2.06(\mathrm{~m}, 2 \mathrm{H}), 1.76-1.67(\mathrm{~m}, 2 \mathrm{H}), 1.54-1.39(\mathrm{~m}, 2 \mathrm{H}), 1.14-0.85(\mathrm{~m}$, 
9H), $0.75(\mathrm{~d}, J=7.0 \mathrm{~Hz}, 3 \mathrm{H}) \mathrm{ppm} ;{ }^{13} \mathbf{C}\left\{{ }^{1} \mathbf{H}\right\} \mathbf{N M R}\left(125 \mathrm{MHz}, \mathrm{CDCl}_{3}, 298 \mathrm{~K}\right): \delta_{\mathrm{C}} 158.4,138.4$, $118.3,82.3,77.9,48.1,40.2,34.6,31.5,26.2,23.9,22.2,20.8,16.7$ ppm; HRMS $m / z$ (DART): calcd for $\mathrm{C}_{16} \mathrm{H}_{24} \mathrm{OI}(\mathrm{M}+\mathrm{H})$ : 359.0866; found: 359.0857 .

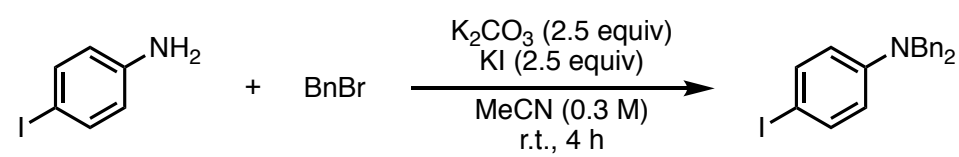

$\boldsymbol{N}, \boldsymbol{N}$-Dibenzyl-4-iodoaniline (S32): To a flame-dried 250-mL flask with stir bar were added MeCN (50 mL, $0.30 \mathrm{M})$, 4-iodoaniline $(3.3 \mathrm{~g}, 15 \mathrm{mmol}, 1.0$ equiv), potassium carbonate $(5.2 \mathrm{~g}$, $38 \mathrm{mmol}, 2.5$ equiv), potassium iodide ( $6.3 \mathrm{~g}, 38 \mathrm{mmol}, 2.5$ equiv), and benzyl bromide ( $4.5 \mathrm{~mL}$, $38 \mathrm{mmol}, 2.5$ equiv). The reaction was stirred at r.t. for $4 \mathrm{~h}$ and was quenched with $\mathrm{H}_{2} \mathrm{O}$. The solution was extracted with EtOAc $(\times 3)$ and the organic fractions were combined, washed with brine $(\times 1)$, dried over $\mathrm{MgSO}_{4}$, and concentrated. The crude residue was purified by recrystallization (DCM/pentane; 2 crops) to yield $N, N$-dibenzyl-4-iodoaniline as a tan solid (2.9 g, $7.3 \mathrm{mmol}, 49 \%$ ). The analytical data was consistent with literature. ${ }^{32}$

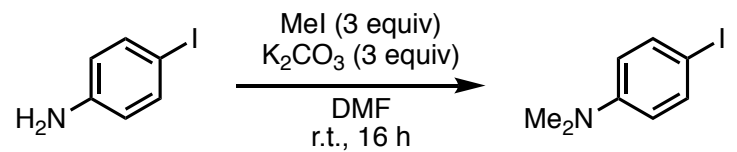

4-Iodo- $\mathbf{N}, \mathbf{N}$-dimethylaniline (S33): To a $100-\mathrm{mL}$ flask with a stir bar were added 4 -iodoaniline ( $3.1 \mathrm{~g}, 14 \mathrm{mmol}, 1.0$ equiv), potassium carbonate (5.8 g, $42 \mathrm{mmol}, 3.0$ equiv), DMF ( $35 \mathrm{~mL}$, $0.40 \mathrm{M})$, and iodomethane $(2.6 \mathrm{~mL}, 42 \mathrm{mmol}, 3.0$ equiv), and the solution was stirred at r.t. for $16 \mathrm{~h}$. The reaction was quenched with $\mathrm{H}_{2} \mathrm{O}$ and extracted with EtOAc $(\times 3)$, and the organic layers were combined, washed with brine $(\times 1)$, dried over $\mathrm{MgSO}_{4}$, and concentrated. The crude residue was purified by flash column chromatography (gradient of $0-20 \%$ EtOAc/hexanes) to yield the product as a blue solid $(0.64 \mathrm{~g}, 2.6 \mathrm{mmol}, 19 \%)$. Analytical data: ${ }^{33}{ }^{1} \mathbf{H}$ NMR (400 MHz, $\left.\mathrm{CDCl}_{3}, 298 \mathrm{~K}\right): \delta_{\mathrm{H}} 7.50-7.42(\mathrm{~m}, 2 \mathrm{H}), 6.54-6.44(\mathrm{~m}, 2 \mathrm{H}), 2.92(\mathrm{~s}, 6 \mathrm{H}) \mathrm{ppm} ;{ }^{13} \mathbf{C}\left\{{ }^{1} \mathbf{H}\right\} \mathbf{N M R}(100$ $\left.\mathrm{MHz} \mathrm{CDCl}_{3}, 298 \mathrm{~K}\right): \delta_{\mathrm{C}} 150.2,137.7,114.9,77.6,40.5 \mathrm{ppm}$.

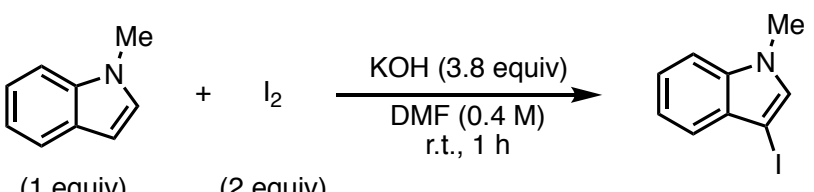

3-Iodo-1-methyl-1 $\boldsymbol{H}$-indole (S34): ${ }^{34}$ To a flame-dried $25-\mathrm{mL}$ flask with stir bar were added $\mathrm{KOH}(0.60 \mathrm{~g}, 15 \mathrm{mmol}, 3.8$ equiv) and DMF (10 mL, $0.40 \mathrm{M})$. 1-Methylindole $(0.50 \mathrm{~mL}, 4.0$ mmol, 1.0 equiv) was added, followed by iodine $(2.0 \mathrm{~g}, 8.0 \mathrm{mmol}, 2.0$ equiv). The reaction was stirred at r.t. for $1 \mathrm{~h}$ and was quenched with $\mathrm{H}_{2} \mathrm{O}$. The solution was extracted with EtOAc $(\times 3)$ and the organic fractions were combined, washed with brine $(\times 1)$, dried over $\mathrm{MgSO}_{4}$, and concentrated. The crude residue was purified by flash column chromatography (gradient of 0 $10 \% \mathrm{EtOAc} /$ hexanes $)$ to yield the product as a white solid $(0.96 \mathrm{~g}, 3.7 \mathrm{mmol}, 93 \%)$. Analytical data: ${ }^{35}{ }^{1} \mathbf{H}$ NMR $\left(400 \mathrm{MHz}, \mathrm{CDCl}_{3}, 298 \mathrm{~K}\right): \delta_{\mathrm{H}} 7.47-7.42(\mathrm{~m}, 1 \mathrm{H}), 7.33-7.27(\mathrm{~m}, 2 \mathrm{H}), 7.24$ $7.18(\mathrm{~m}, 1 \mathrm{H}), 7.14(\mathrm{~s}, 1 \mathrm{H}), 3.81(\mathrm{~s}, 3 \mathrm{H}) \mathrm{ppm} ;{ }^{\mathbf{1 3}} \mathbf{C}\left\{{ }^{\mathbf{1}} \mathbf{H}\right\} \mathbf{~ N M R}\left(100 \mathrm{MHz}, \mathrm{CDCl}_{3}, 298 \mathrm{~K}\right): \delta_{\mathrm{C}}$ $136.9,132.9,130.6,122.8,121.3,120.4,109.5,54.9,33.2$ ppm; $\mathbf{R}_{\mathbf{f}}(9: 1$ hexanes/EtOAc; $\left.\mathrm{UV} / \mathrm{KMnO}_{4}\right): 0.59$. 


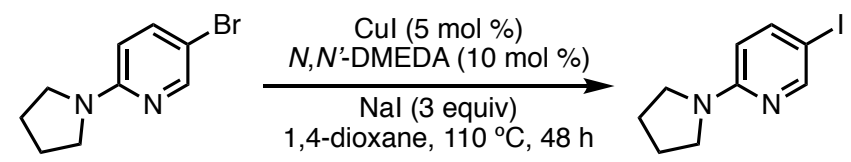

5-Iodo-2-(pyrrolidin-1-yl)pyridine (S35): ${ }^{36}$ To a flame-dried 16-mL threaded culture tube with a stir bar was added copper(I) iodide $(20 \mathrm{mg}, 0.10 \mathrm{mmol}, 5 \mathrm{~mol} \%)$, and the tube was sealed with a size 19 septum and evacuated and backfilled with $\mathrm{N}_{2}(\times 3)$. 1,4-Dioxane $(6.7 \mathrm{~mL}, 0.30 \mathrm{M})$ was added, followed by $N, N^{\prime}$-dimethylethylenediamine $(22 \mu \mathrm{L}, 0.20 \mathrm{mmol}, 10 \mathrm{~mol} \%)$, and the solution was stirred at r.t. for $1 \mathrm{~min}$. The reaction tube was briefly opened to air and 5-bromo-2(pyrrolidin-1-yl)pyridine ( $0.40 \mathrm{~g}, 2.0 \mathrm{mmol}, 1.0$ equiv) was added, and the solution was stirred for another $1 \mathrm{~min}$ at r.t. The reaction tube was briefly opened to air and sodium iodide $(0.89 \mathrm{~g}$, $6.0 \mathrm{mmol}, 3.0$ equiv) was added. The tube was sealed, quickly evacuated and backfilled with $\mathrm{N}_{2}$ $(\times 3)$, and stirred at $110^{\circ} \mathrm{C}$ for $48 \mathrm{~h}$. The solution was cooled to r.t., filtered over a plug of Celite and silica, and the filter cake was washed with EtOAc $(\times 3)$. The organic filtrate layers were combined and concentrated. The crude residue was purified by flash column chromatography (gradient of 10-20\% EtOAc/hexanes) to yield the product as a white solid (0.44 g, $1.6 \mathrm{mmol}$, 80\%). ${ }^{1} \mathbf{H}$ NMR $\left(500 \mathrm{MHz}, \mathrm{CDCl}_{3}, 298 \mathrm{~K}\right): \delta_{\mathrm{H}} 8.26(\mathrm{~d}, J=2.3 \mathrm{~Hz}, 1 \mathrm{H}), 7.60-7.56(\mathrm{~m}, 1 \mathrm{H}), 6.19$ $(\mathrm{dd}, J=9.0,0.9 \mathrm{~Hz}, 1 \mathrm{H}), 3.43-3.36(\mathrm{~m}, 4 \mathrm{H}), 2.03-1.97(\mathrm{~m}, 4 \mathrm{H}) \mathrm{ppm} ;{ }^{13} \mathbf{C}\left\{{ }^{1} \mathbf{H}\right\} \mathbf{N M R}(125 \mathrm{MHz}$, $\mathrm{CDCl}_{3}, 298 \mathrm{~K}$ ): $\delta_{\mathrm{C}} 156.0,153.8,144.4,109.0,74.8,46.9,25.7 \mathrm{ppm}$; HRMS $\mathrm{m} / z$ (DART): calcd for $\mathrm{C}_{9} \mathrm{H}_{12} \mathrm{~N}_{2} \mathrm{I}(\mathrm{M}+\mathrm{H})$ : 275.0040; found: 275.0032; m.p.: $101-102^{\circ} \mathrm{C}$. 


\section{G. Kinetic data}

Procedure for kinetic studies: Performed on $0.20-\mathrm{mmol}$ scale according to General Procedure A using $\alpha$-magnesiated nitrile (1) prepared from $\alpha$-methylbenzyl cyanide and $\mathrm{PhMgBr} \cdot \mathrm{LiBr}$ (see Section B), with the modification that $n$-dodecane ( $45 \mu \mathrm{L}, 0.20 \mathrm{mmol}, 1.0$ equiv) was also added to the reaction as an internal standard for GC-MS analysis. Reactions were performed under positive pressure of $\operatorname{Ar}$ (balloon), and aliquots were taken using a 1-mL syringe equipped with a 4 -inch needle. Before addition of nitrile $\alpha$-anion (1), the solution was submerged in a pre-heated $30^{\circ} \mathrm{C}$ oil bath while stirring. To begin the reaction, a solution of nitrile $\alpha$-anion (1) was added, and $0.20-0.30 \mathrm{~mL}$ aliquots were taken at 10 -second intervals and immediately quenched with $\mathrm{MeOH}(0.50 \mathrm{~mL})$. Aliquots were treated with sat. aq. $\mathrm{NH}_{4} \mathrm{Cl}$ and extracted with EtOAc $(\times 2)$, and the organic fractions were combined, filtered over a plug of $\mathrm{MgSO}_{4}$ and Celite, and analyzed by GC-MS. Absolute reaction rates vary day-to-day (empirically, $\pm 10 \%$ ) due to minor differences in the $\alpha$-anion solution (prepared fresh daily), which in turn affects catalyst speciation and activation. Thus, each set of experiments was performed using the same solution of $\alpha$-anion on the same day, which gave reliable data.

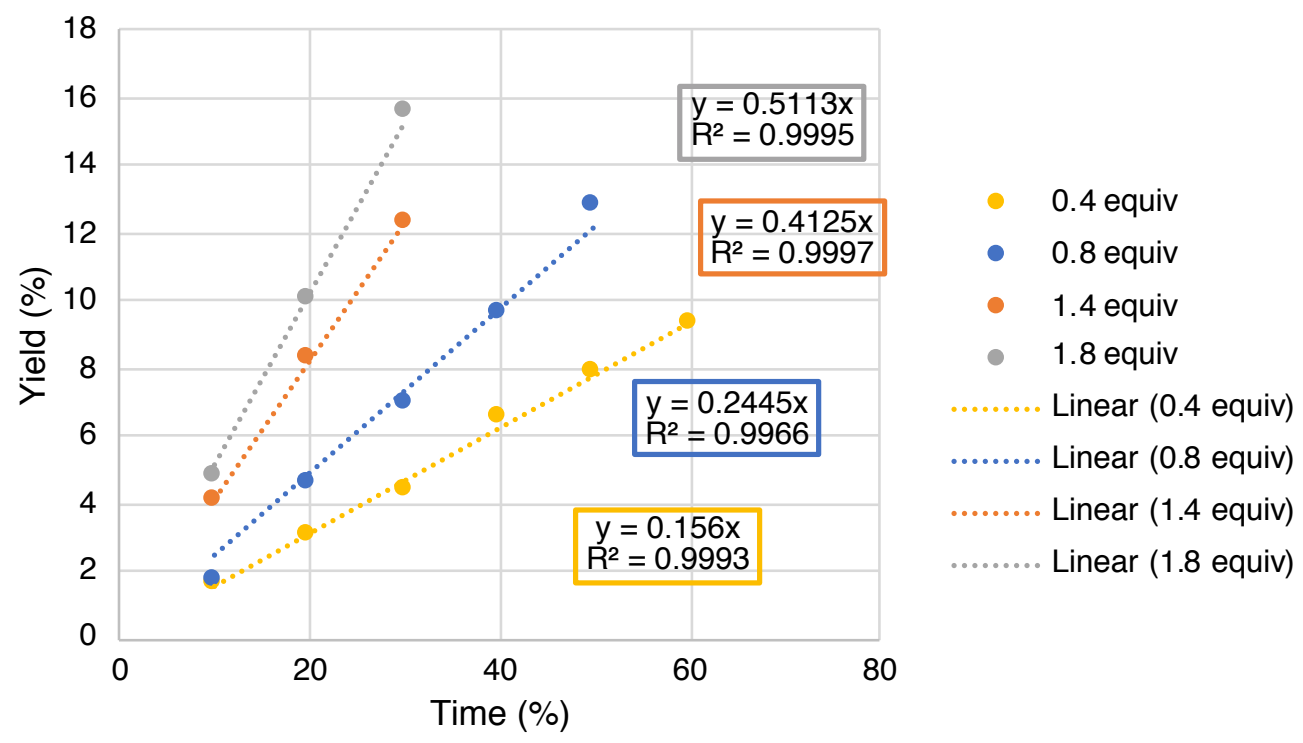

Figure S17. Initial rates according to equiv $4-\mathrm{OMePhI}$ measured to ca. $10 \%$ conversion, trendlines fitted to the origin 


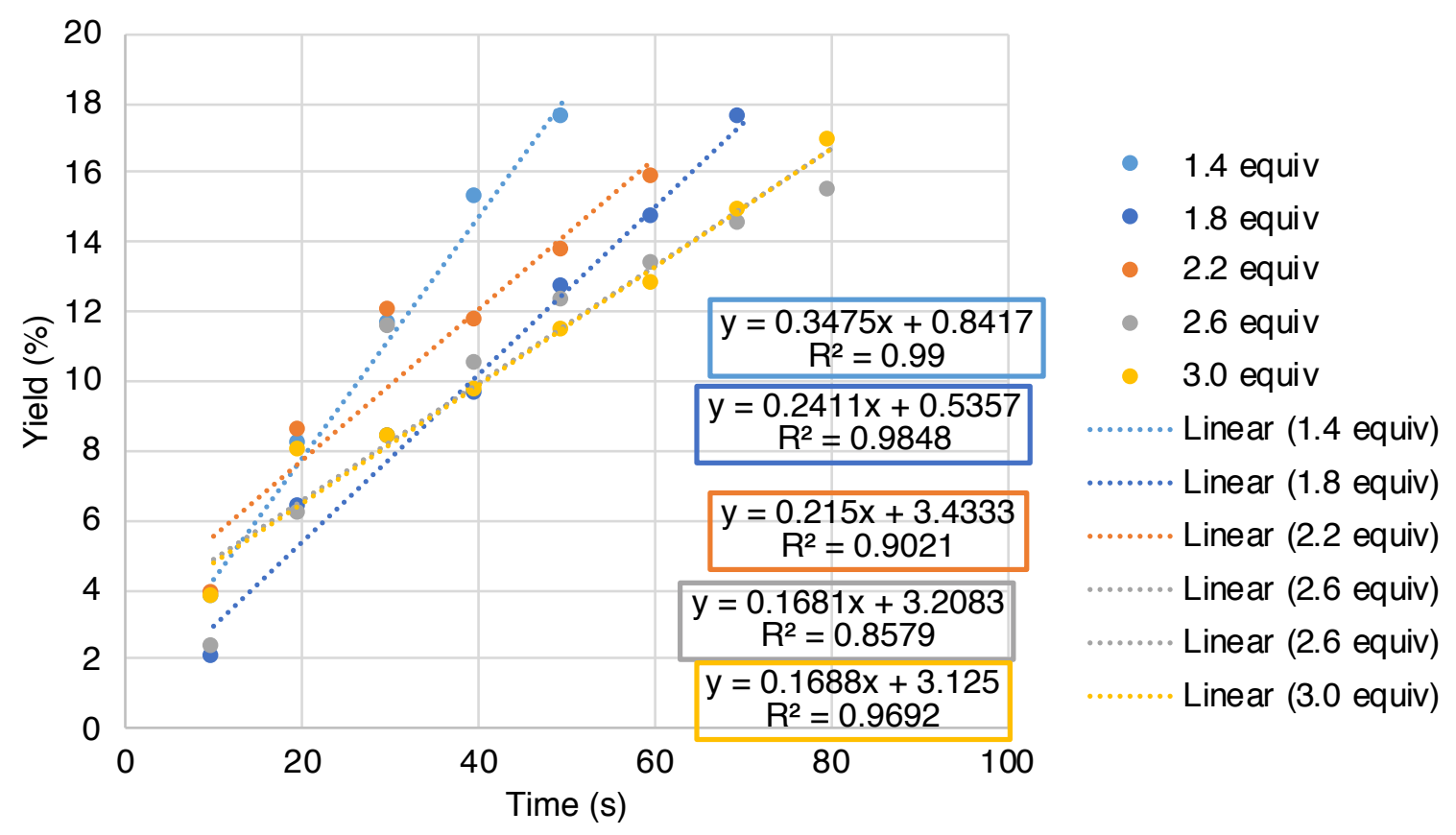

Figure S18. Initial rates according to equiv $\alpha$-anion (1), measured to $15 \%$ conversion

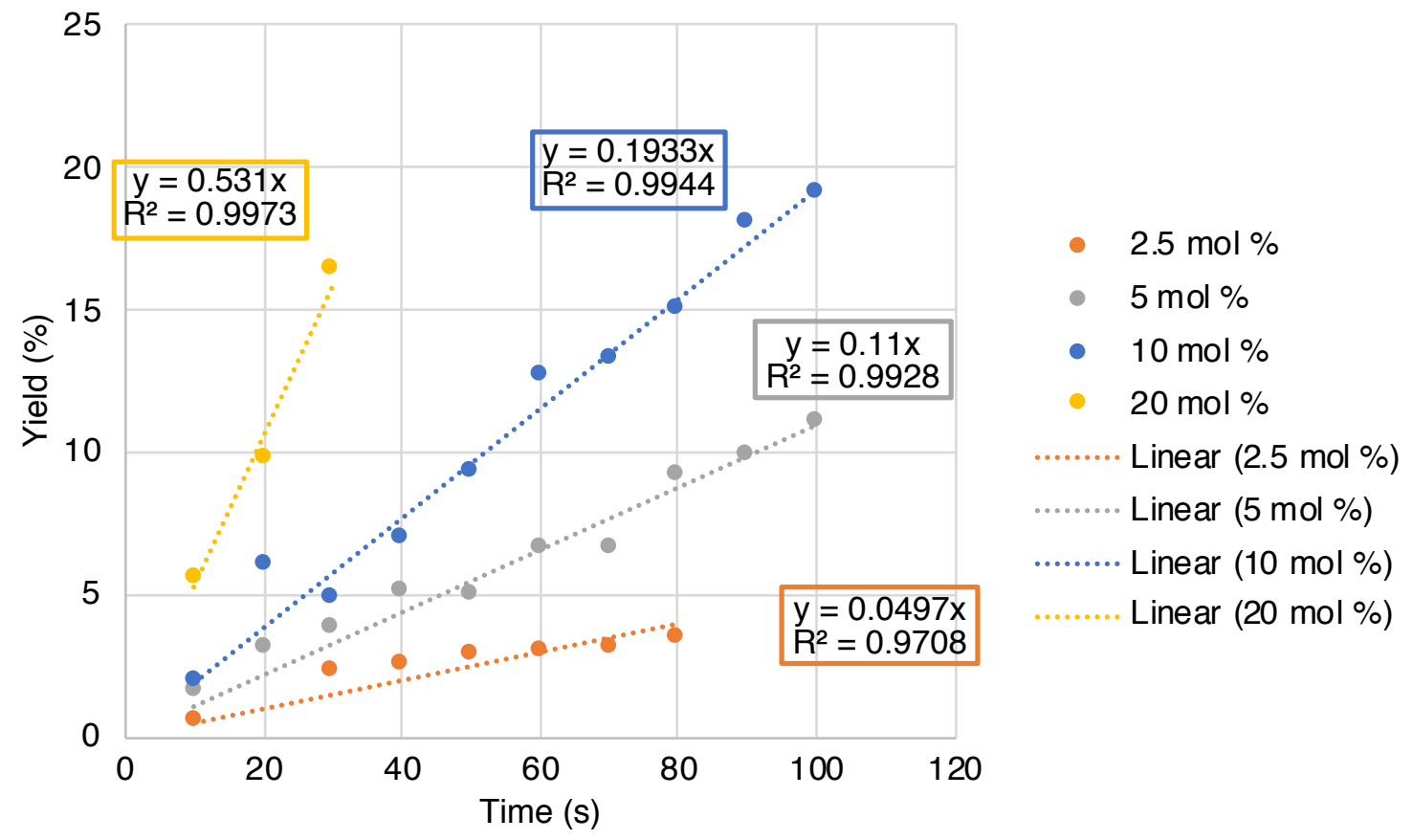

Figure 19. Initial rates according to catalyst loading $\left(\mathbf{L 3} / \mathrm{NiCl}_{2}(\mathrm{dme})\right.$ ratio $\left.=1.2 / 1\right)$, measured to ca. $15 \%$ conversion, trendlines fitted to the origin 


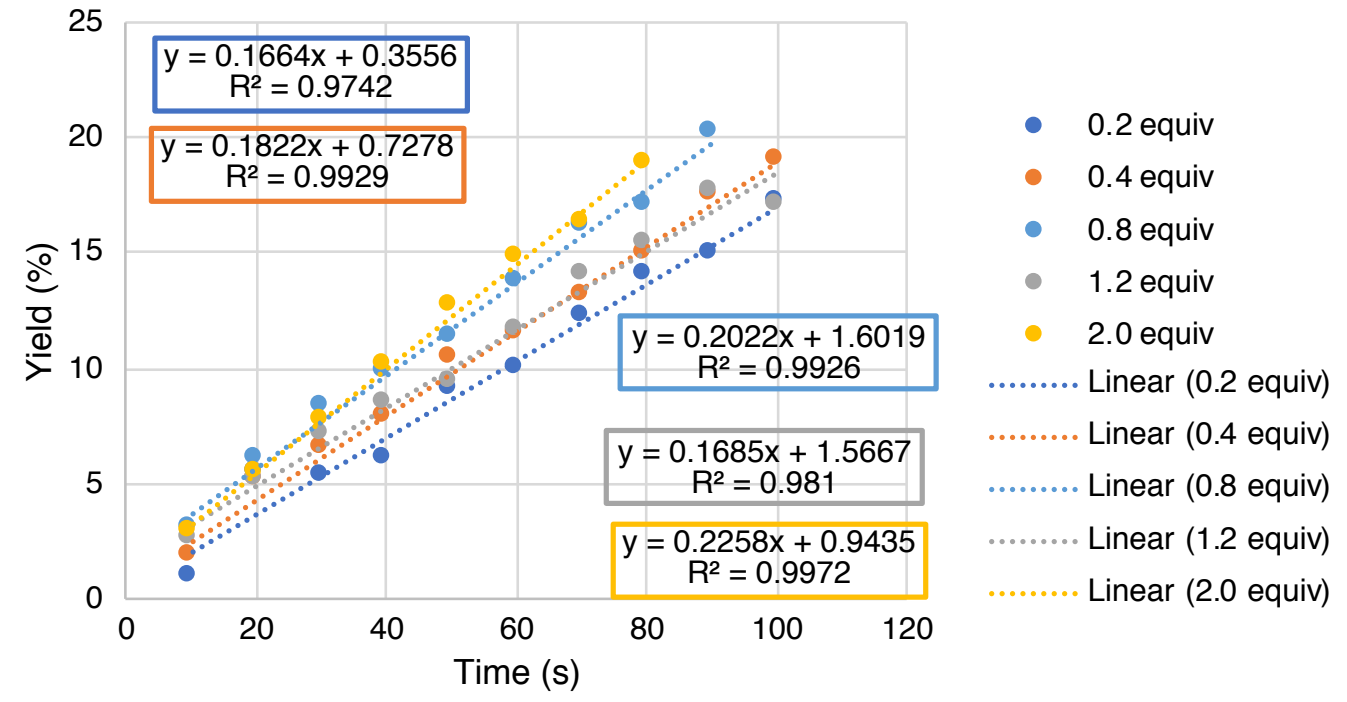

Figure 20. Initial rates according to product additive (2a), measured to $20 \%$ conversion
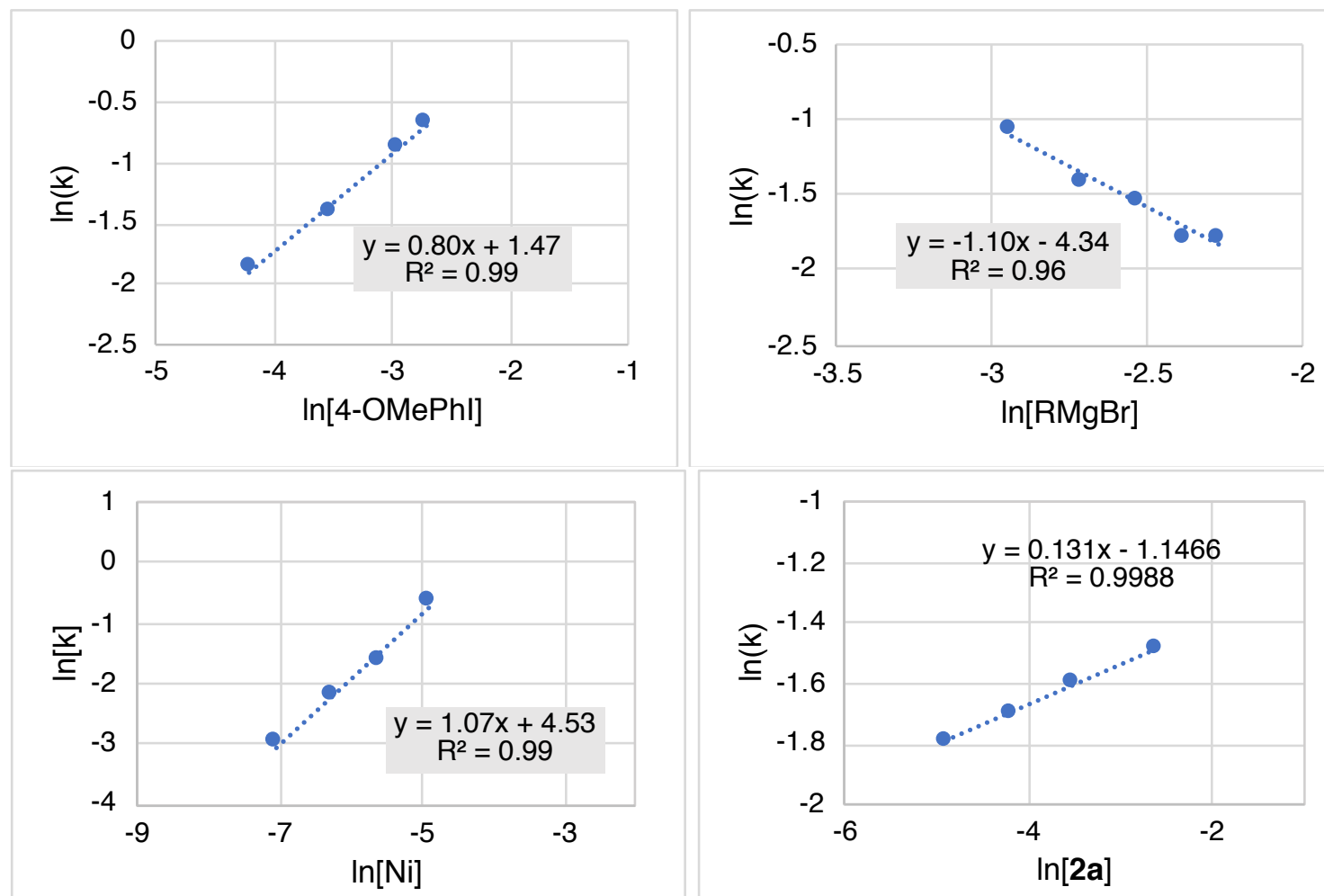

Figure 21. Approximate order in 4-OMePhI (Top Left), $\alpha$-anion (1) (Top Right), catalyst (Bottom Left), and product (2a) (Bottom Right) 


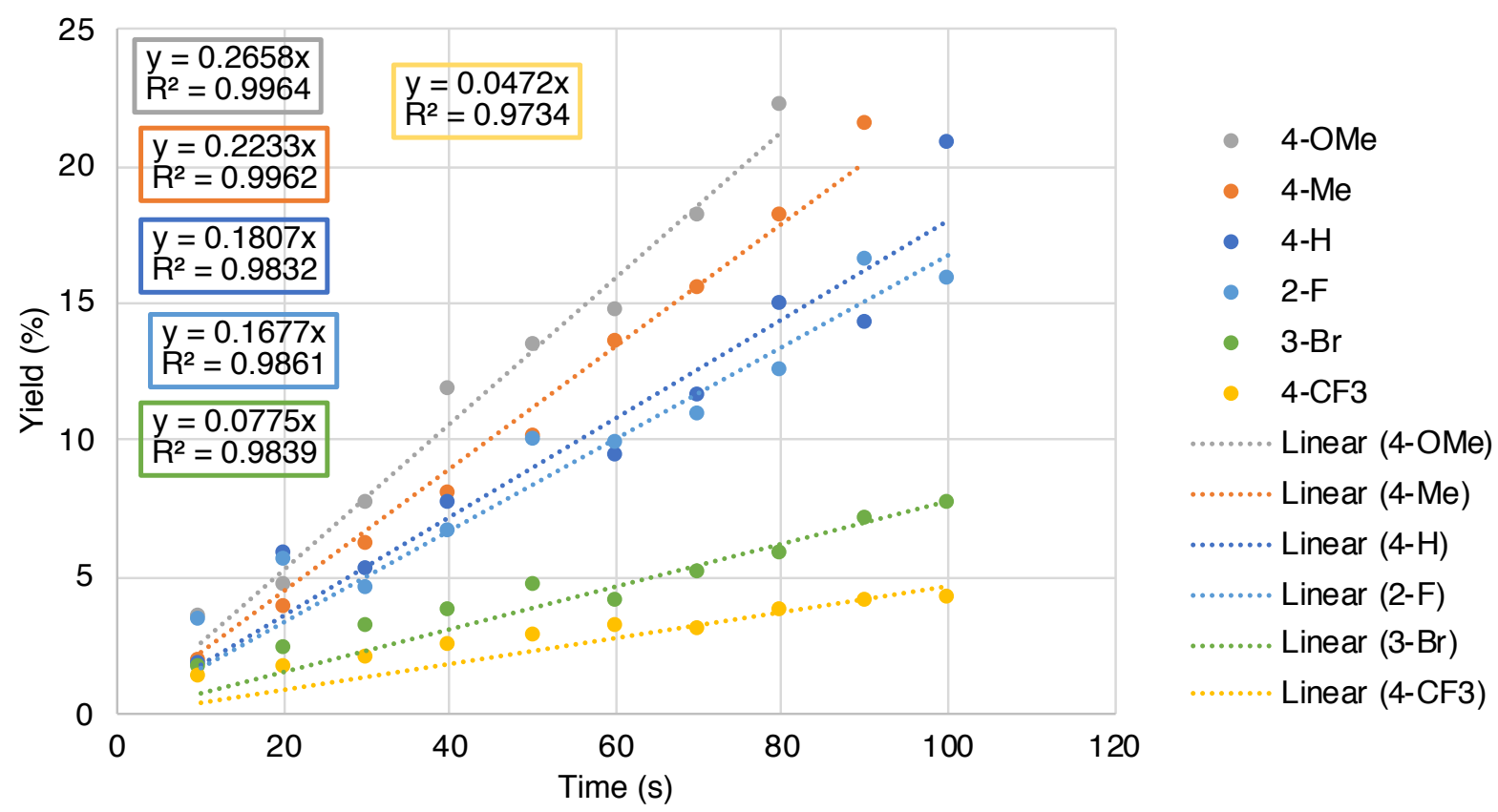

Figure 22. Initial rates according to ligand structure (substituents with respect to nitrile) measured to $100 \mathrm{~s}$ or $20 \%$ conversion (whichever comes first), trendlines fitted to the origin 


\section{H. Hammett study with respect to $4-\mathrm{X}-\mathrm{C}_{6} \mathrm{H}_{4} \mathrm{I}$}
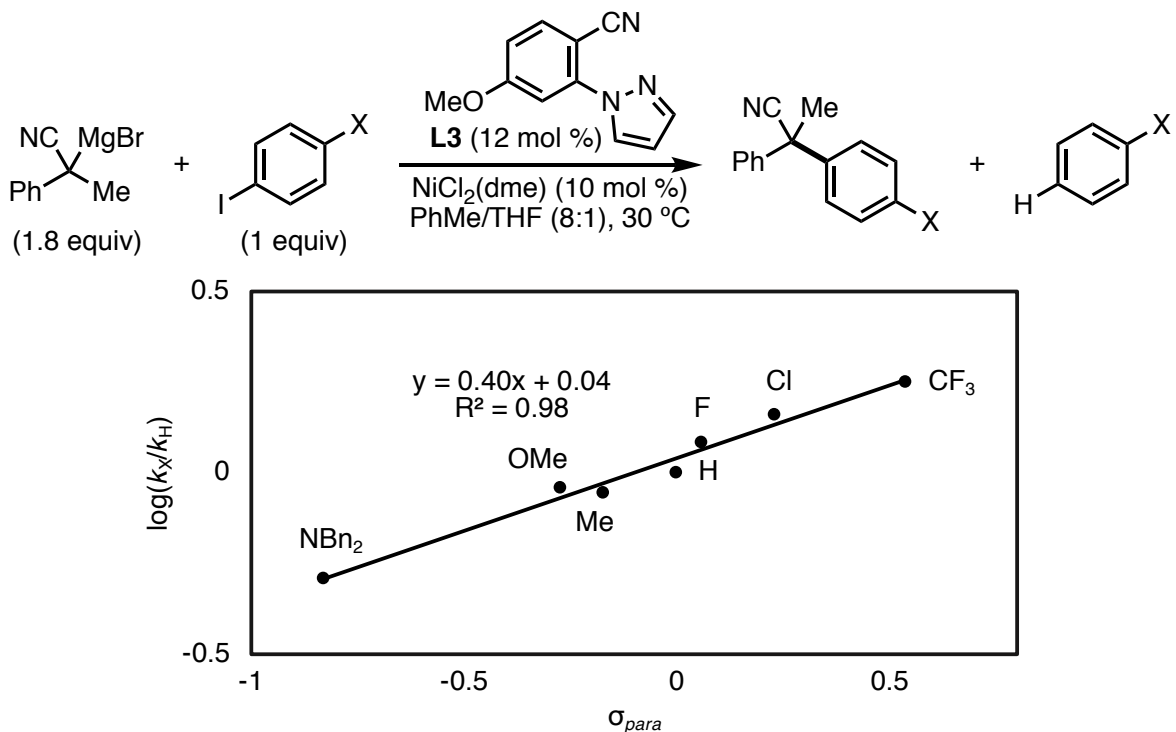

Figure 23. Comparison of initial reaction rates versus $\sigma_{\text {para }}$ values for $4-\mathrm{X}-\mathrm{C}_{6} \mathrm{H}_{4} \mathrm{I}$

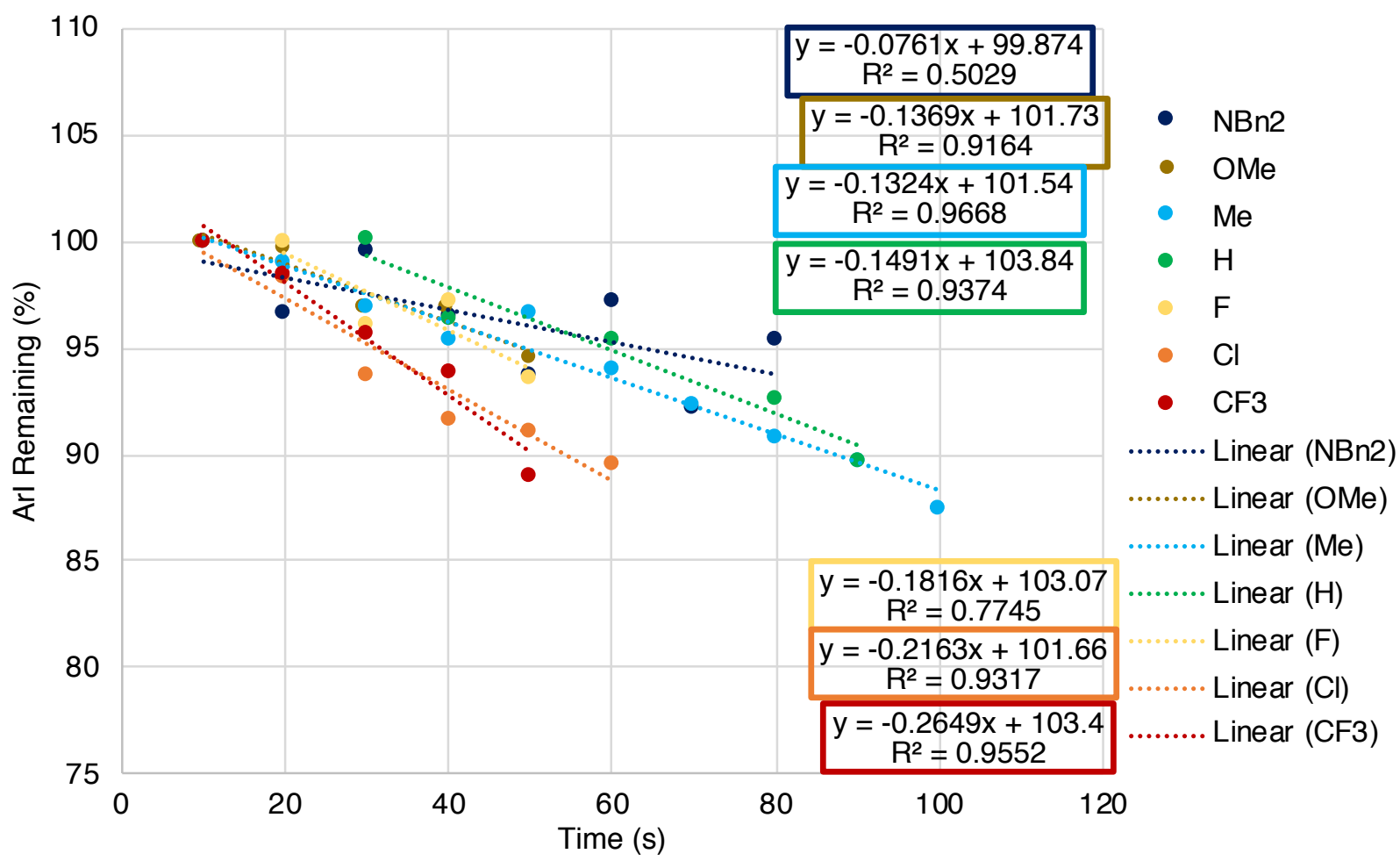

Figure S24. Initial rates for Hammett study, measured to $10 \%$ conversion. Within each experiment, outliers due to GC-MS error were removed 


\section{References}

${ }^{1}$ Boudier, A.; Breuil, P.-A. R.; Magna, L.; Olivier-Bourbigou, H.; Braunstein, P. J. Organomet. Chem. 2012, 718, 31-37.

${ }^{2}$ Yu, F.; McConnell, M. S.; Nguyen, H. M. Org. Lett. 2015, 17, 2018-2021.

${ }^{3} \mathrm{Wu}, \mathrm{K}$; Doyle, A. G. Nat. Chem. 2017, 9, 779-784.

${ }^{4}$ McKennon, M. J.; Meyers, A. I. J. Org. Chem. 1993, 58, 3568-3571.

${ }^{6}$ Purzycki, M.; Liu, W.; Hilmersson, G.; Fleming, F. F. Chem. Commun. 2013, 41, 4700-4702.

${ }^{6}$ Zhang, L.; Yang, F.; Tao, G.; Qiu, L.; Duan, Z.; Mathey, F. Eur. J. Inorg. Chem. 2017, 23552362.

${ }^{7}$ Jin, J.; Wen, Q.; Lu, P.; Wang, Y. Chem. Commun. 2012, 48, 9933-9935.

${ }^{8}$ Carreño, M. C.; Gacría Ruano, J. L.; Sanz, G.; Toledo, M. A.; Urbano, A. J. Org. Chem. 1995, 60, 5328-5331.

${ }^{9}$ Akgun, B.; Hall, D. G. Angew. Chem. Int. Ed. 2016, 55, 3909-3913.

${ }^{10}$ Kelly, S. M. Helv. Chim. Acta. 1984, 67, 1572-1579.

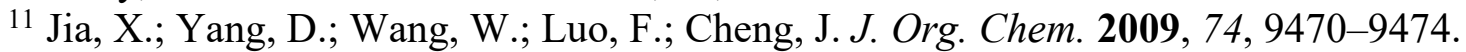

12 Du, B.; Jiang, X.; Sun, P. J. Org. Chem. 2013, 78, 2786-2791.

${ }^{13}$ Viss, G.; Eichner, S. Adv. Synth. Catal. 2000, 342, 201-204.

${ }^{14}$ Kamenecka, T. M.; Jiang, R.; Song, X.; Lograsso, P.; Cameron, M. D. WO Patent 2009032861 A1, Sept. 3, 2008.

15 Jia, X.; Yang, D.; Zhang, S.; Cheng, J. Org. Lett. 2009, 11, 4716-4719.

${ }^{16}$ Shiraishi, M.; Seto, M.; Aikawa, K.; Kanzaki, N.; Baba, M. EP Patent 1593673A1, Sept. 11, 2005.

${ }^{17}$ Qi-Lin, Z.; Pfaltz, A. Tetrahedron 1994, 50, 4467-4478.

${ }^{18}$ Huang, C.; Wang, H.; Wang, X.; Gao, K.; Wu, J.; Hou, H.; Fan, Y. Chem. Eur. J. 2016, 22, 6389-6396.

19 Thompson, A. D.; Huestis, M. P. J. Org. Chem. 2013, 78, 762-769.

${ }^{20}$ Yang, Q.; Wang, Y.; Yang, L.; Zhang, M. Tetrahedron 2013, 69, 6230-6233.

${ }^{21}$ Patra, T.; Agasti, S.; Maiti, A.; Maiti, D. Chem. Commun. 2013, 49, 69-71.

22 Krasovskiy, A.; Knochel, P. Synthesis 2006, 890-891.

${ }^{23}$ Too, P. C.; Chan, G. H.; Tnay, Y. L.; Hirao, H.; Chiba, S. Angew. Chem. Int. Ed. 2016, 55, 3719-3723.

${ }^{24}$ Davis, W. A.; Cava, M. P. J. Org. Chem. 1983, 48, 2774-2775.

${ }^{25}$ Abbotto, A.; Bradamante, S.; Facchetti, A.; Pagani, G. A. J. Org. Chem. 1997, 62, 5755-5865.

${ }^{26}$ Arnett, E. M.; Molter, K. J. Phys. Chem. 1986, 90, 383-389.

27 Todorovic, N.; Awuah, E.; Albu, S.; Ozimok, C.; Capretta, A. Org. Lett. 2011, 13, 6180-6183.

28 Troughton, E. B.; Molter, K. E.; Arnett, E. M. J. Am. Chem. Soc. 1984, 106, 6726-6735.

${ }^{29}$ Mills, L. R.; Rousseaux, S. A. L. Tetrahedron 2019, 75, 4298-4306.

${ }^{30}$ Ye, F.; Wang, C.; Zhang, Y.; Wang, J. Angew. Chem. Int. Ed. 2014, 53, 11625-11628.

${ }^{31}$ Mitzel, F.; FitzGerald, S.; Beeby, A.; Faust, R. Chem. Eur. J. 2003, 9, 1233-1241.

${ }^{32}$ Matsuda, M.; Hirano, K.; Satoh, T.; Miura, M. Angew. Chem. Int. Ed. 2012, 51, 3642-3645.

${ }^{33}$ Zheng, H.-X.; Shan, X.-H.; Qu, J.-P.; Kang, Y.-B. Org. Lett. 2017, 19, 5114-5117.

${ }^{34}$ Vittorio, B.; Gerardo, P. Synthesis 1982, 1096-1097.

${ }^{35}$ Kim, J.; Kim, H.; Chang, S. Org. Lett. 2012, 14, 3924-3927.

${ }^{36}$ Klapars, A.; Buchwald, S. L. Org. Lett. 2002, 124, 14844-14845. 


\section{J. NMR spectra}

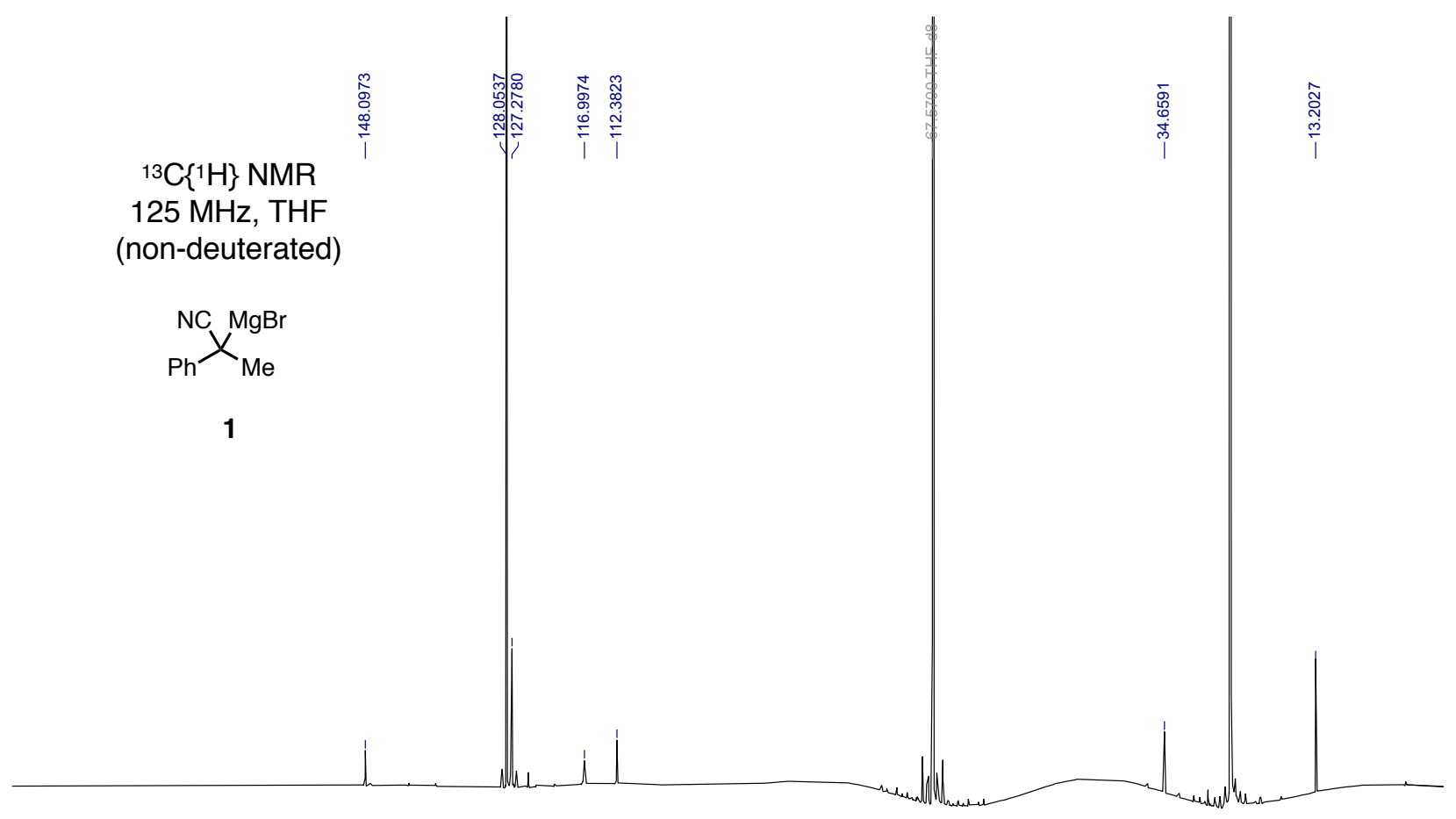




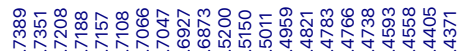

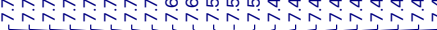

${ }^{1} \mathrm{H}$ NMR

$400 \mathrm{MHz}, \mathrm{CDCl}_{3}$<smiles>N#Cc1ccccc1Br</smiles>

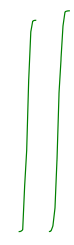

S2

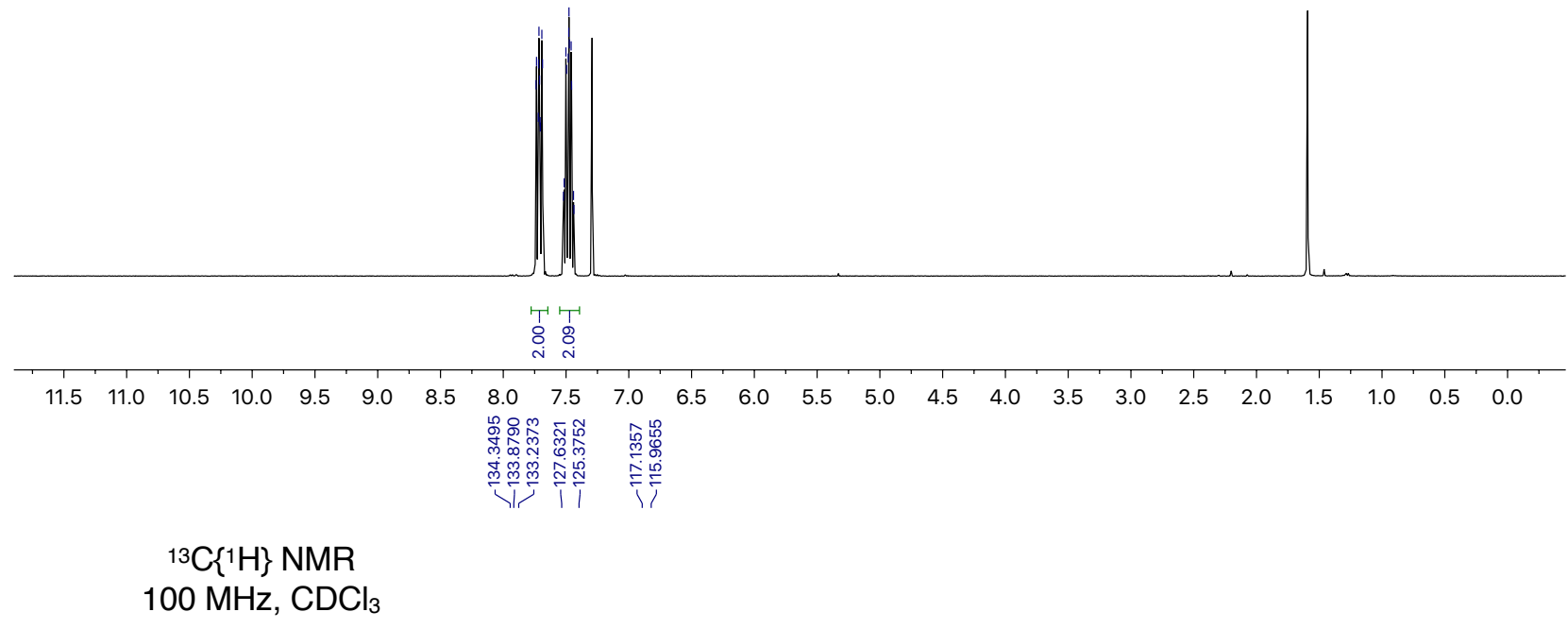<smiles>N#Cc1ccccc1Br</smiles>

S2

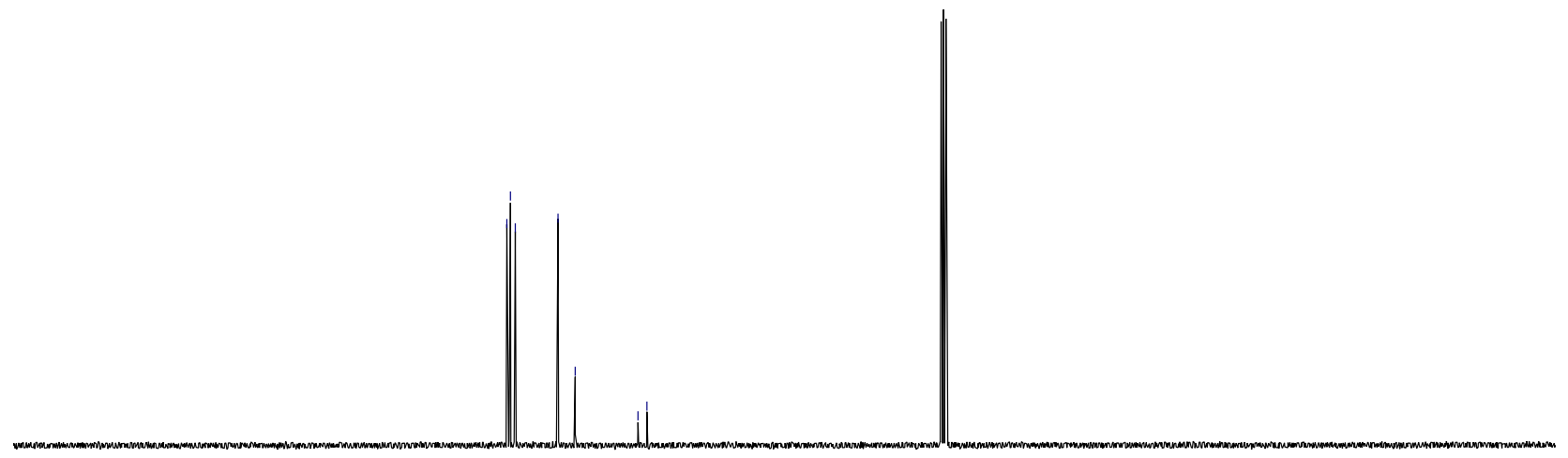



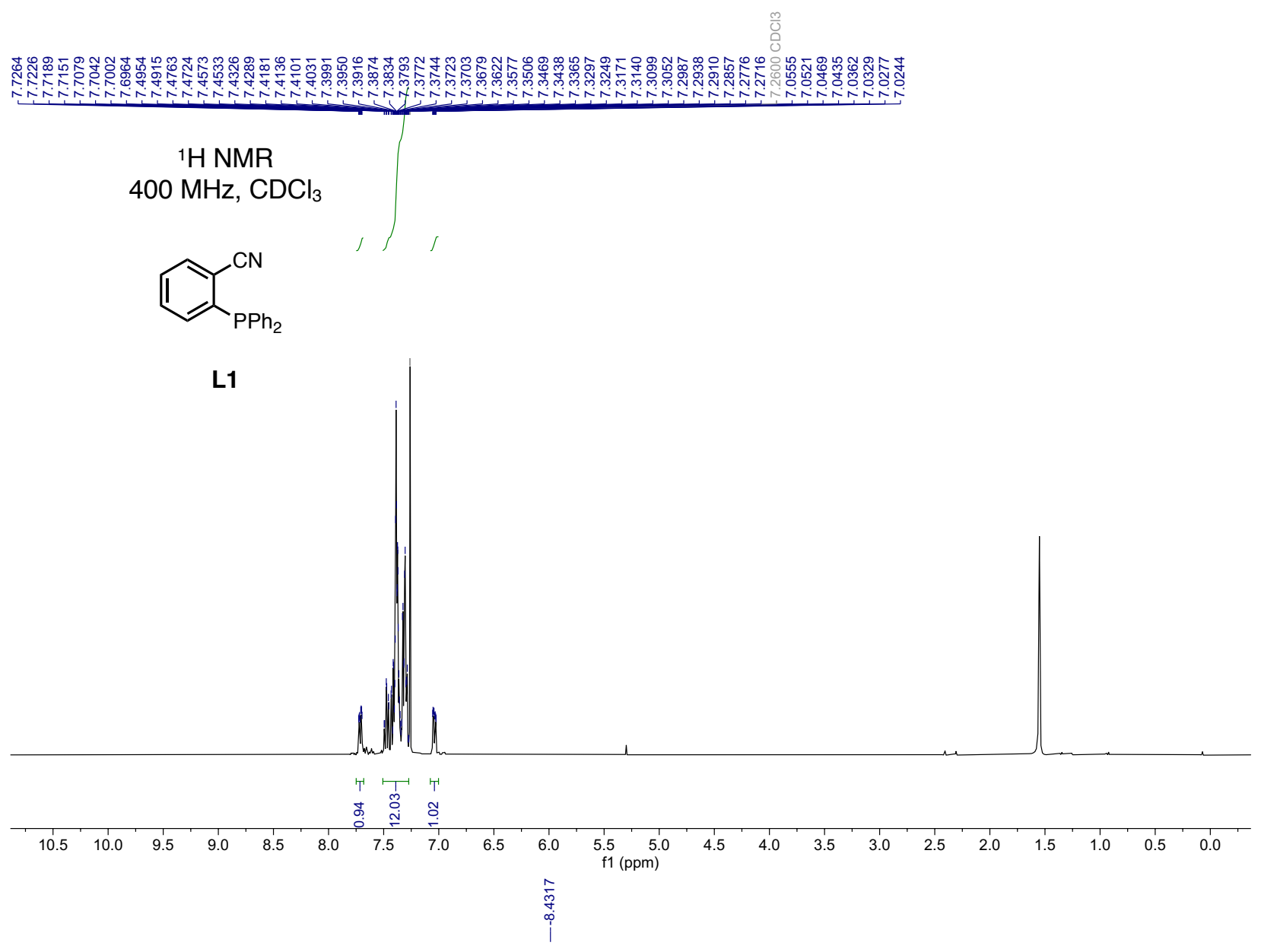

${ }^{31 P}$ NMR

$162 \mathrm{MHz}, \mathrm{CDCl}_{3}$

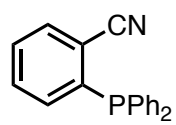

L1

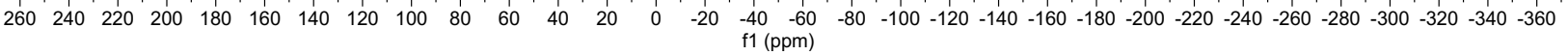




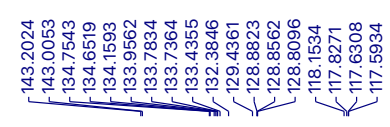

${ }^{13} \mathrm{C}\left\{{ }^{1} \mathrm{H}\right\}$ NMR

$100 \mathrm{MHz}, \mathrm{CDCl}_{3}$

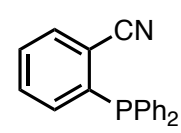

L1

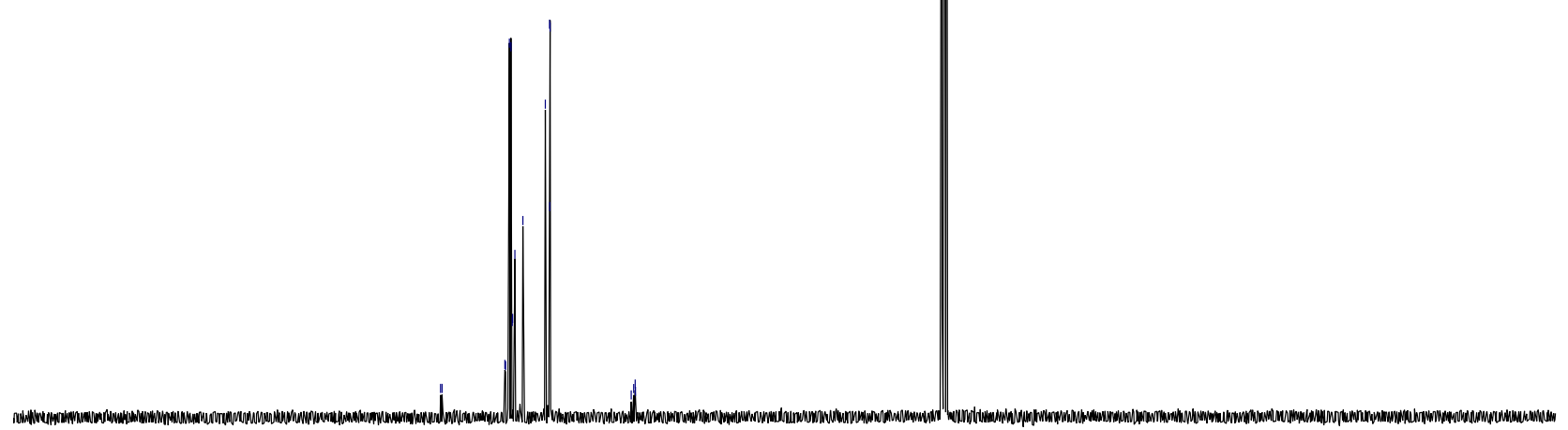

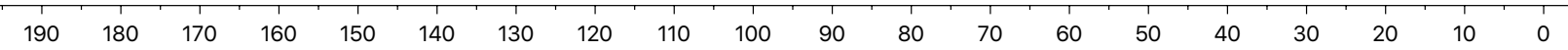




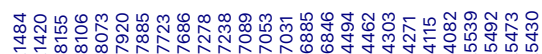

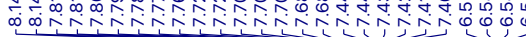

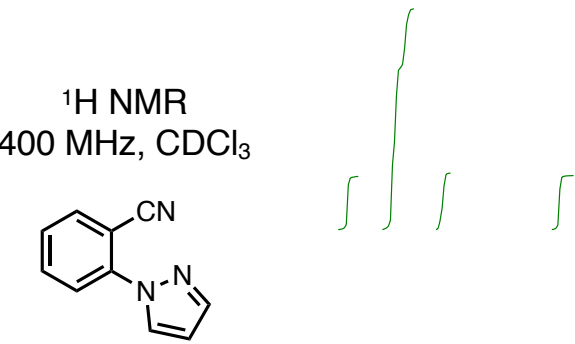

L2

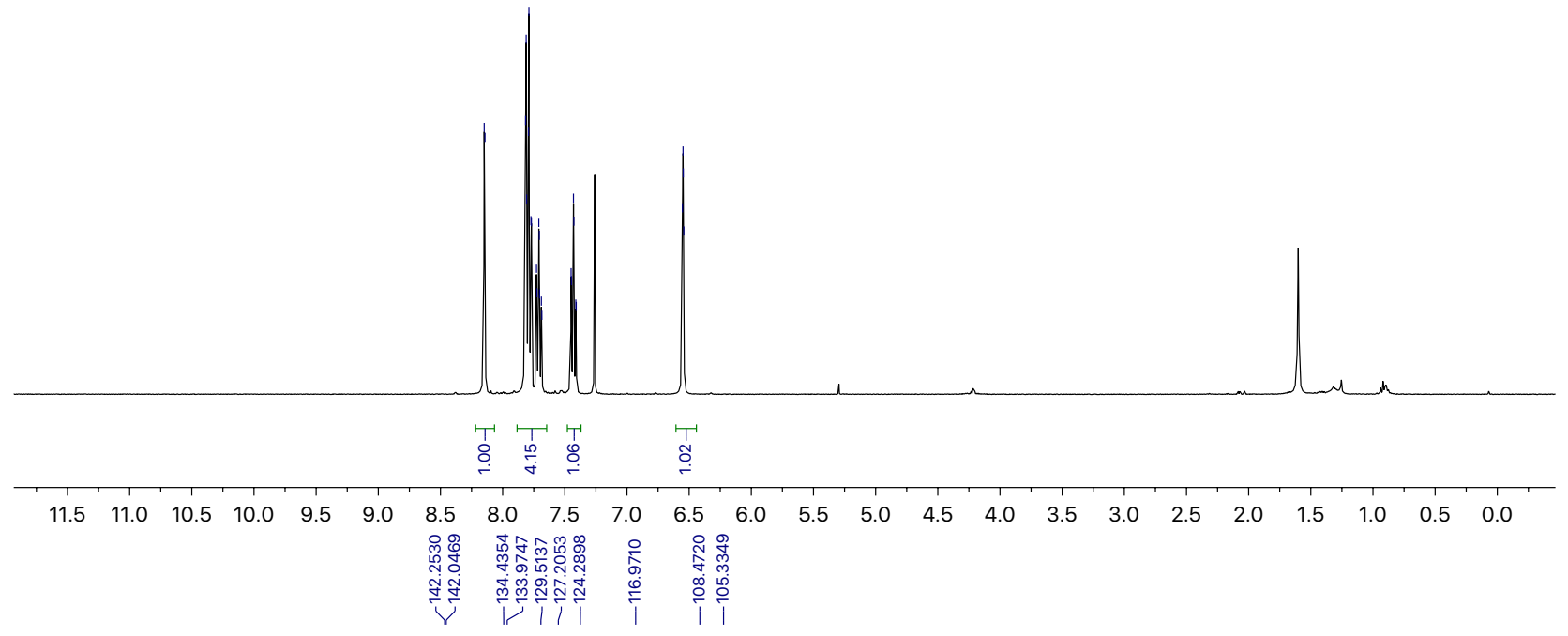

${ }^{13} \mathrm{C}\left\{{ }^{1} \mathrm{H}\right\}$ NMR

$100 \mathrm{MHz}, \mathrm{CDCl}_{3}$<smiles>N#Cc1ccccc1-n1cccn1</smiles>

\section{L2}

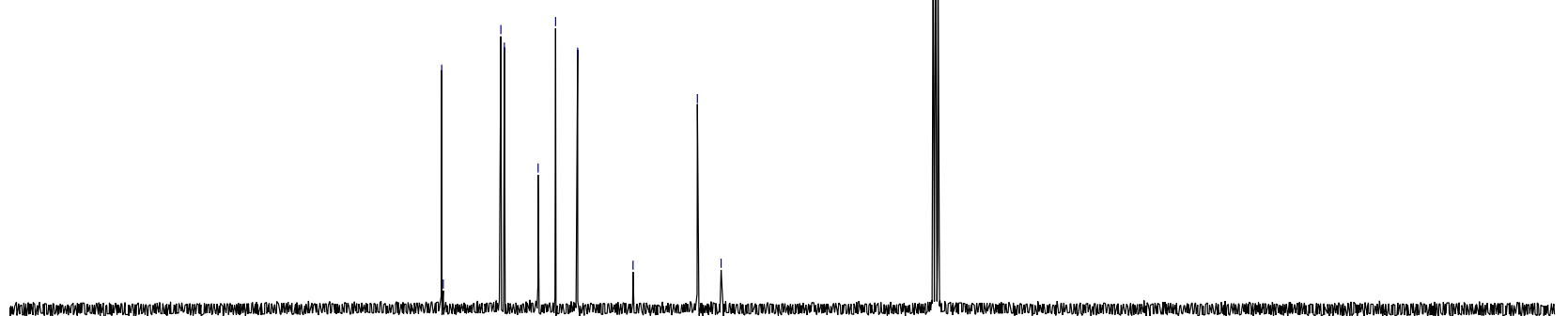


$500 \mathrm{MHz}, \mathrm{CDCl}_{3}$

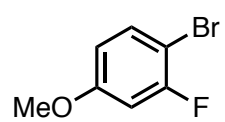

S3 (+regioisomer)

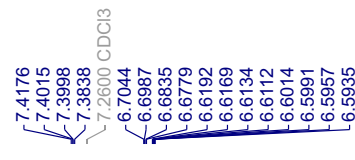

\section{总}

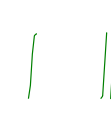




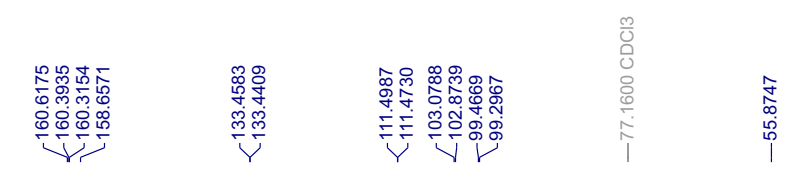

${ }^{13} \mathrm{C}\left\{{ }^{1} \mathrm{H}\right\}$ NMR

$125 \mathrm{MHz}, \mathrm{CDCl}_{3}$

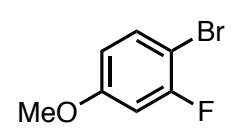

S3 (+regioisomer)

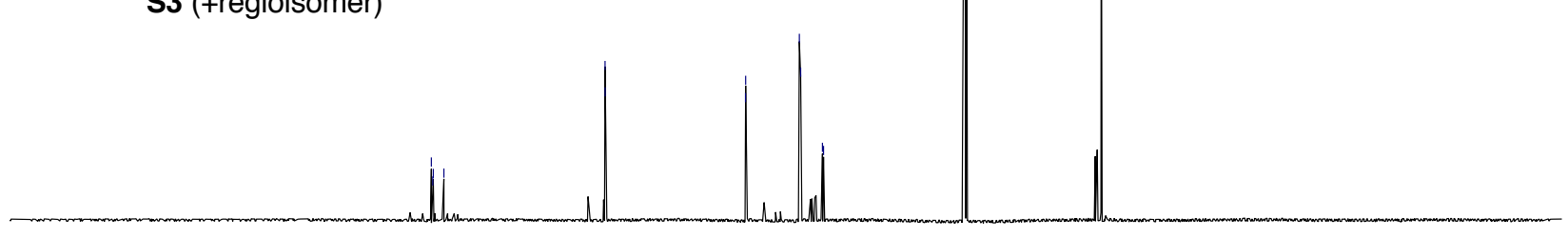

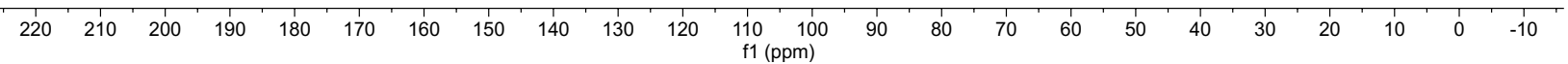


$1 \mathrm{H}$ NMR

$400 \mathrm{MHz}, \mathrm{CDCl}_{3}$
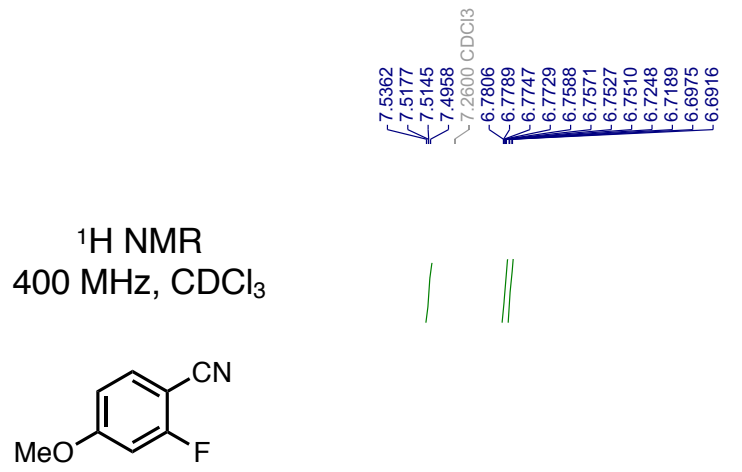

S4

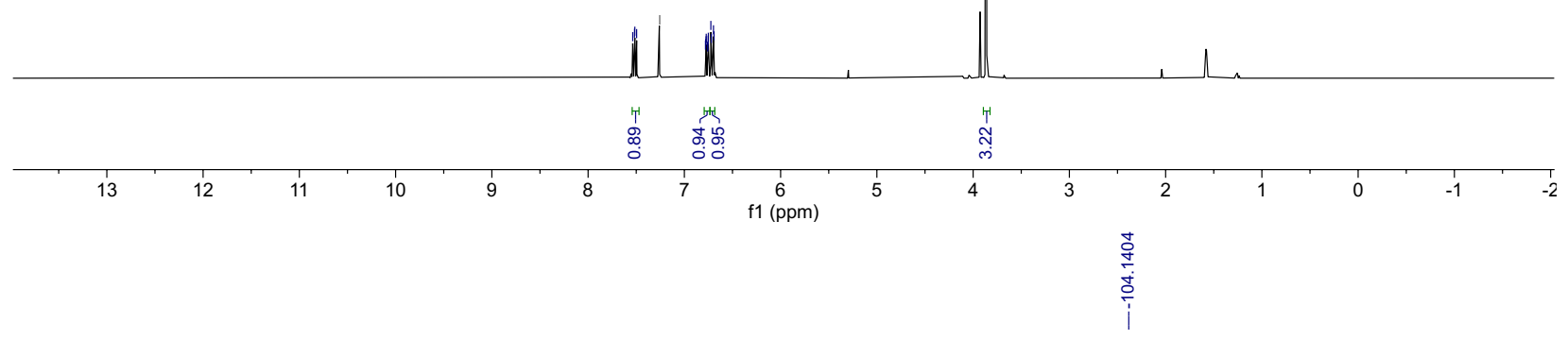

${ }^{19} \mathrm{~F}\left\{{ }^{1} \mathrm{H}\right\}$ NMR

$376 \mathrm{MHz}, \mathrm{CDCl}_{3}$

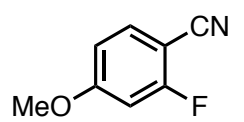

S4

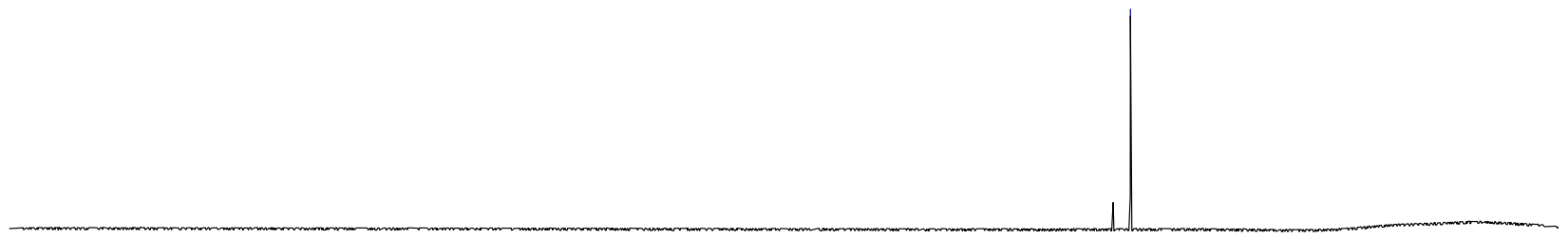

\begin{tabular}{llllllllllllllllllllllllll}
\hline 170 & 150 & 130 & 110 & 90 & 70 & 50 & 30 & 10 & -10 & -30 & -50 & -70 & -90 & -110 & -130 & -150 & -170 & -190 & -210
\end{tabular}




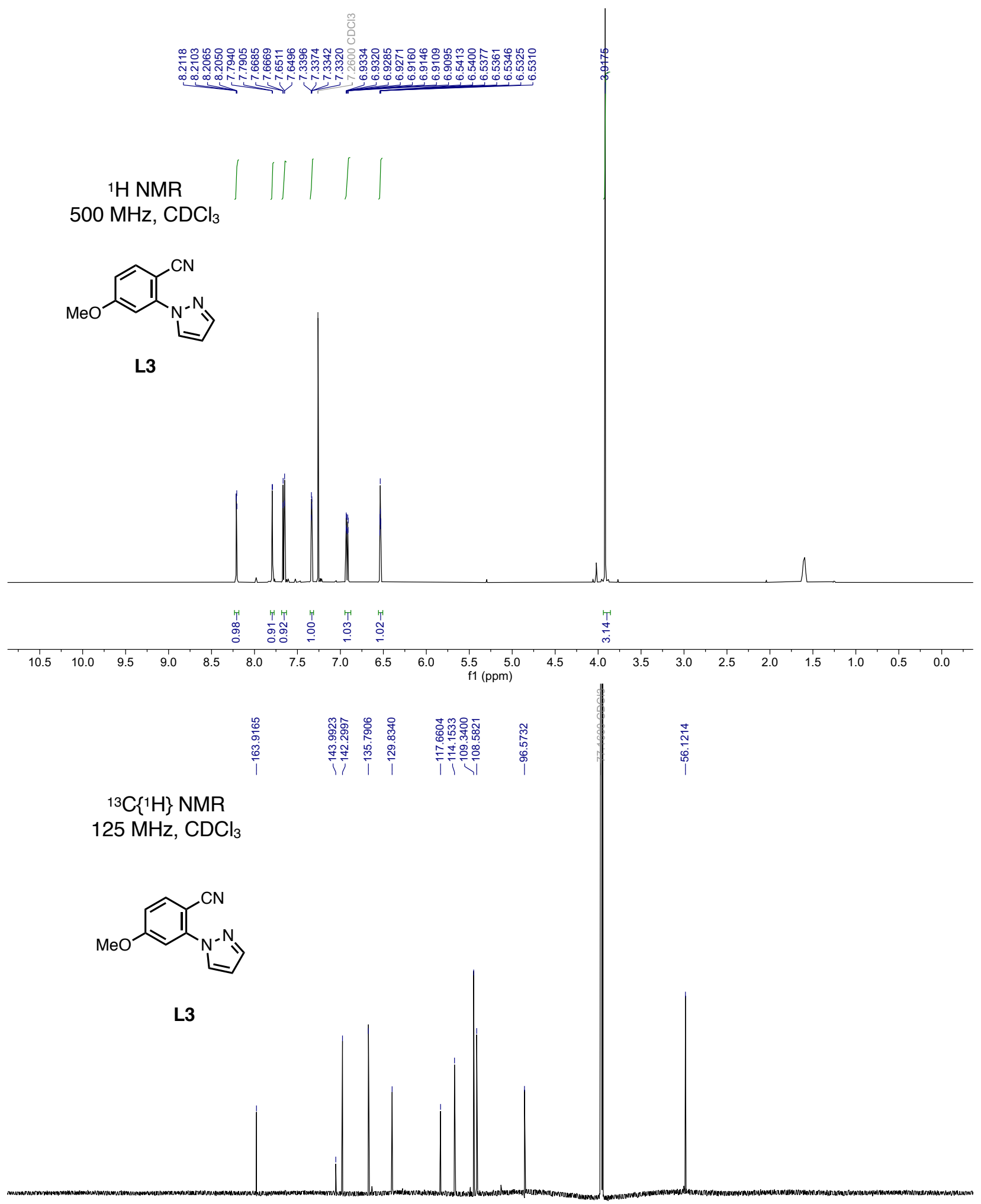

\begin{tabular}{|l|llllllllllllllllllllllll}
\hline 220 & 210 & 200 & 190 & 180 & 170 & 160 & 150 & 140 & 130 & 120 & $\begin{array}{c}110 \\
\mathrm{f} 1(\mathrm{ppm})\end{array}$ & 90 & 80 & 70 & 60 & 50 & 40 & 30 & 20 & 10 & 0 & -10
\end{tabular} 


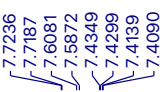

${ }^{1} \mathrm{H}$ NMR

$400 \mathrm{MHz}, \mathrm{CDCl}_{3}$<smiles>N#Cc1ccc(Cl)cc1Br</smiles>

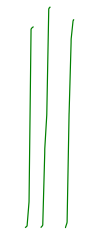

S5

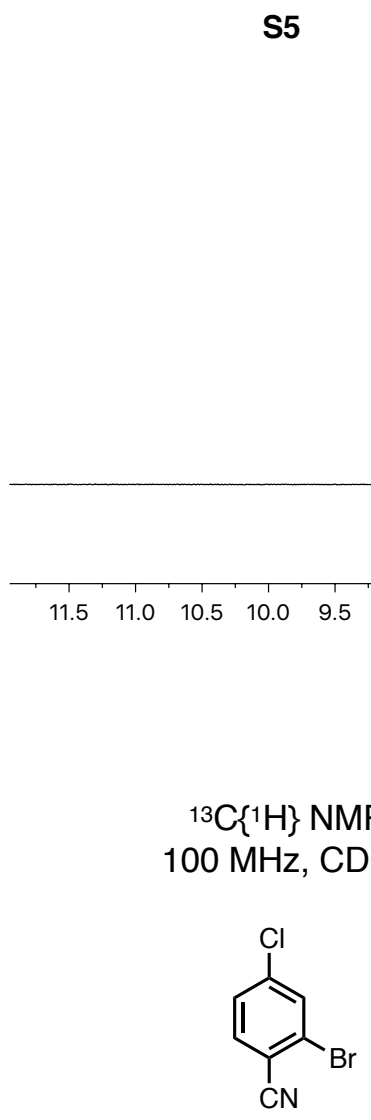

S5

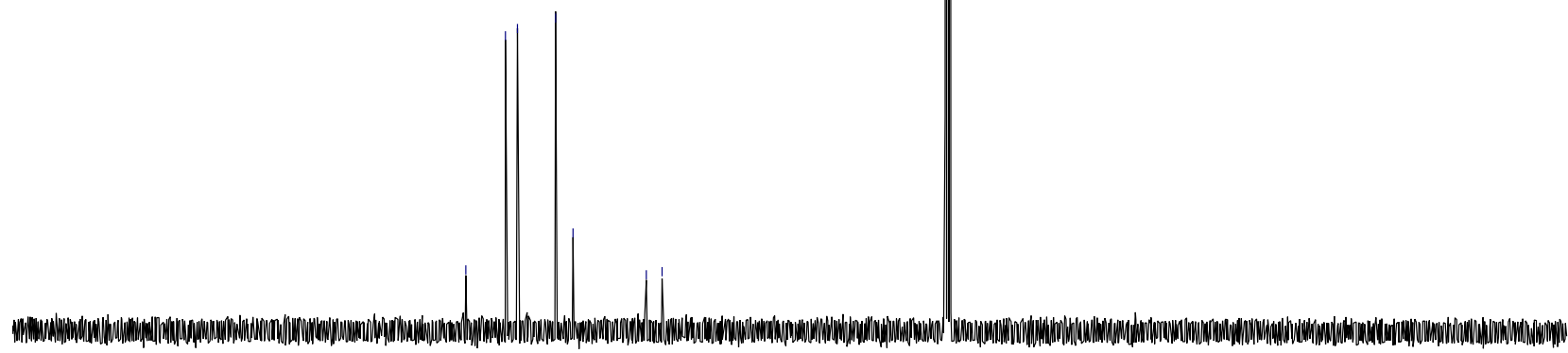

$\begin{array}{llllll}190 & 180 & 170 & 160 & 150 & 140\end{array}$ 
${ }^{1} \mathrm{H}$ NMR

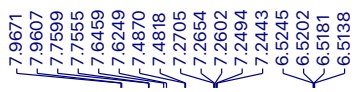

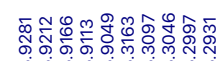

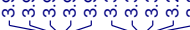

$400 \mathrm{MHz}, \mathrm{CDCl}_{3}$<smiles>N#Cc1ccc(N2CCOCC2)cc1-n1cccn1</smiles>

L4
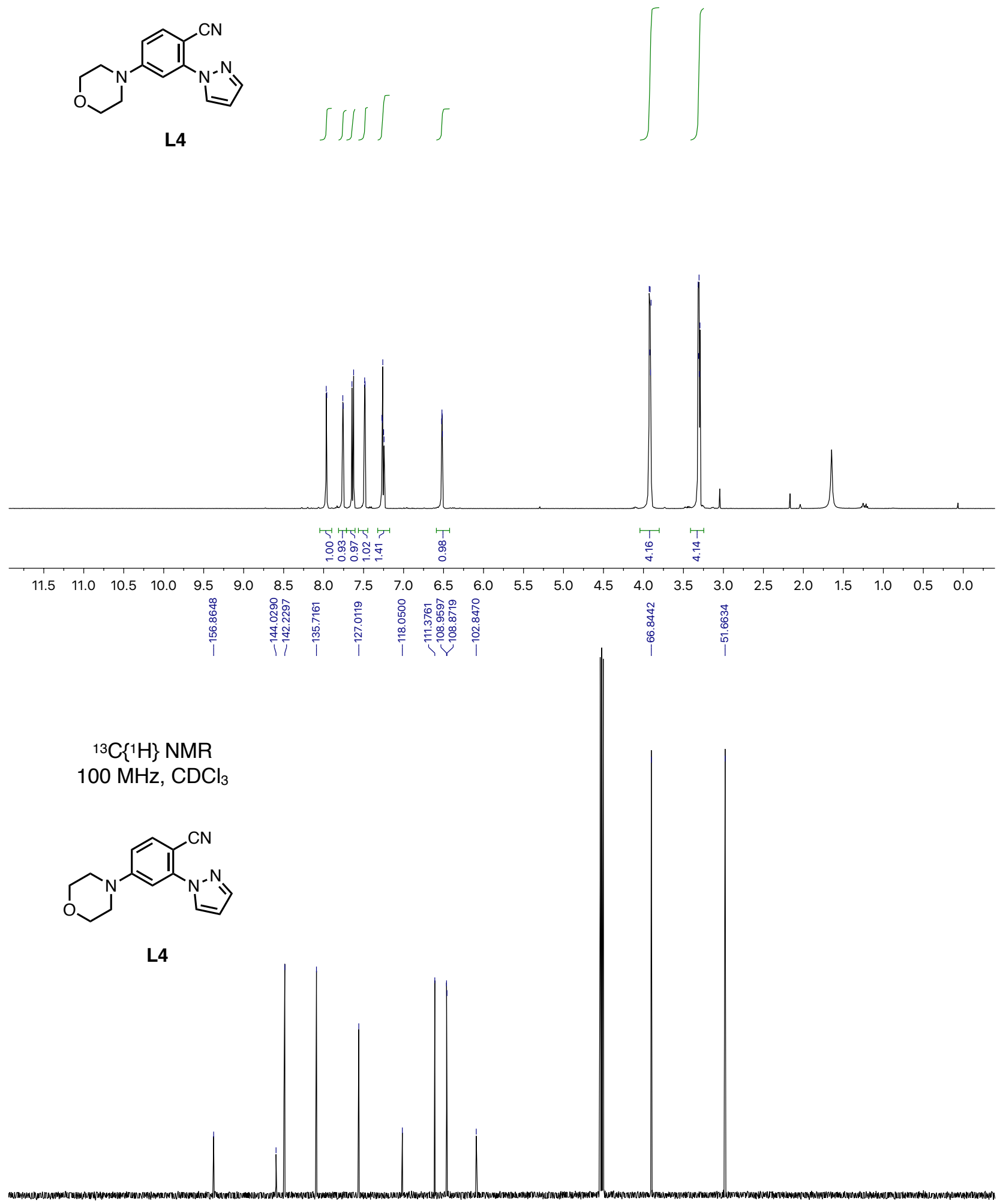


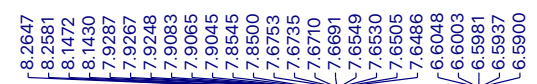

$1 \mathrm{H}$ NMR

$400 \mathrm{MHz}, \mathrm{CDCl}_{3}$<smiles>N#Cc1ccc(C(F)(F)F)cc1-n1cccn1</smiles>

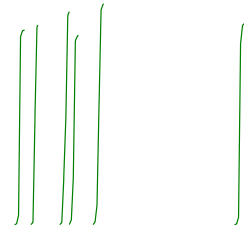

L5

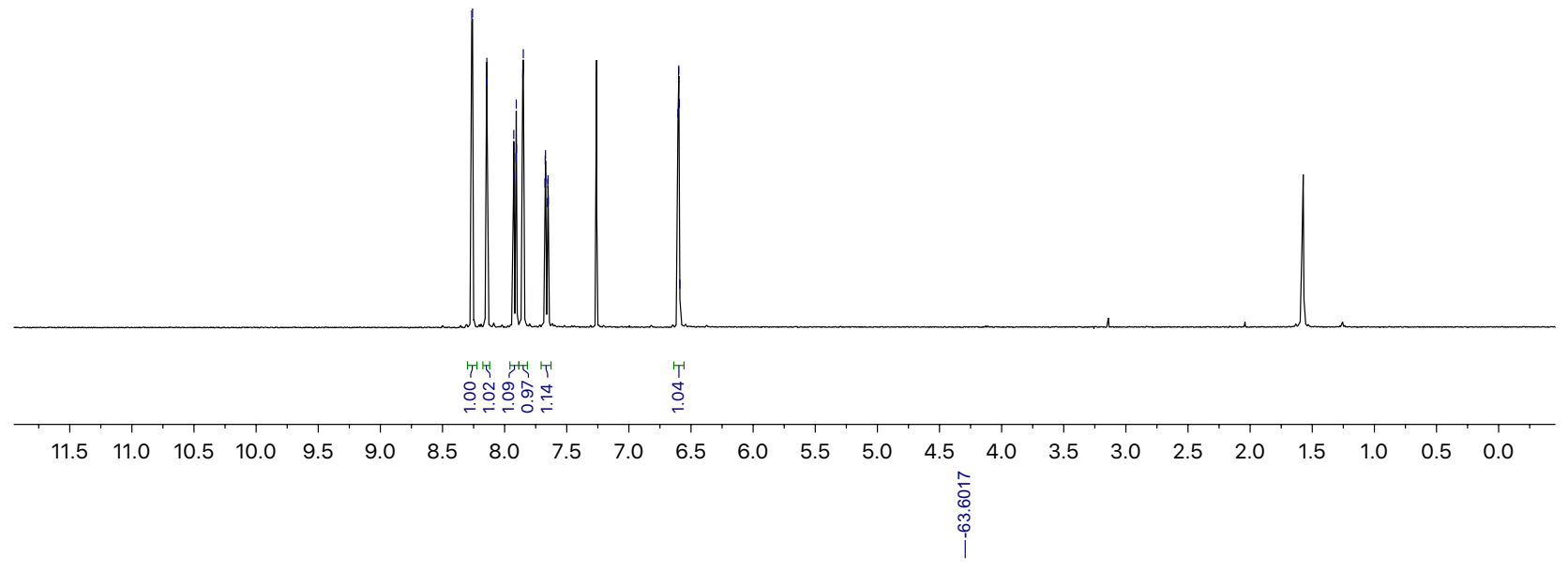

${ }^{19} \mathrm{~F}\{1 \mathrm{H}\}$ NMR

$376 \mathrm{MHz} \mathrm{CDCl}_{3}$

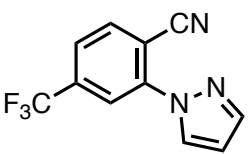

L5

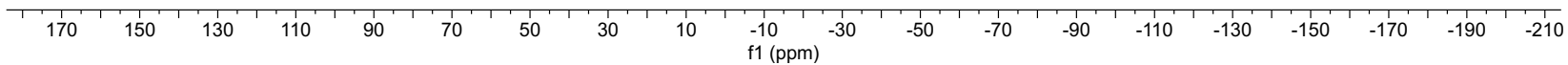




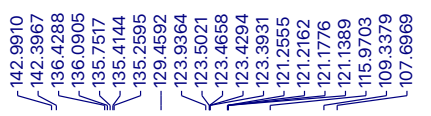

${ }^{13} \mathrm{C}\left\{{ }^{1} \mathrm{H}\right\}$ NMR

$100 \mathrm{MHz}, \mathrm{CDCl}_{3}$

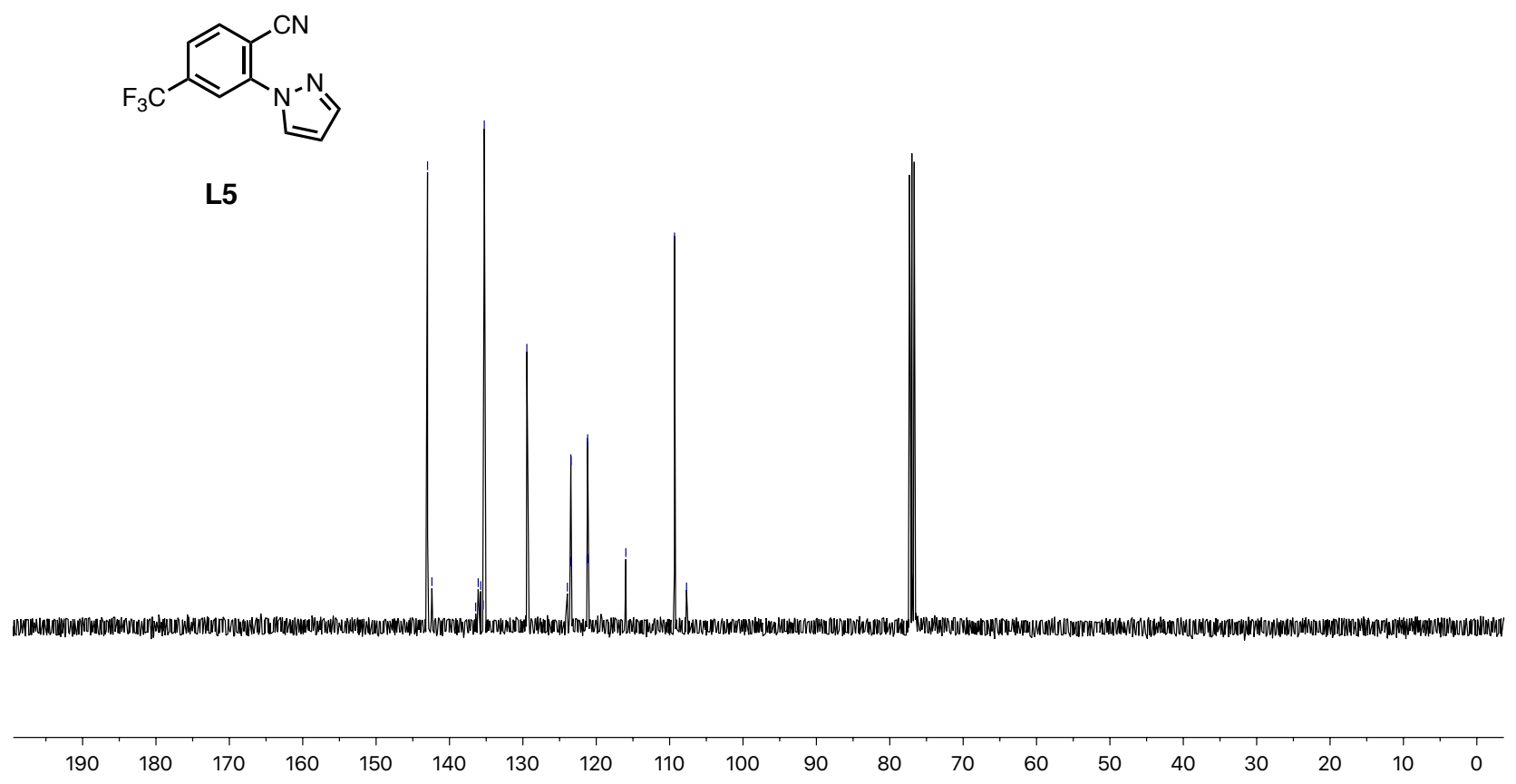




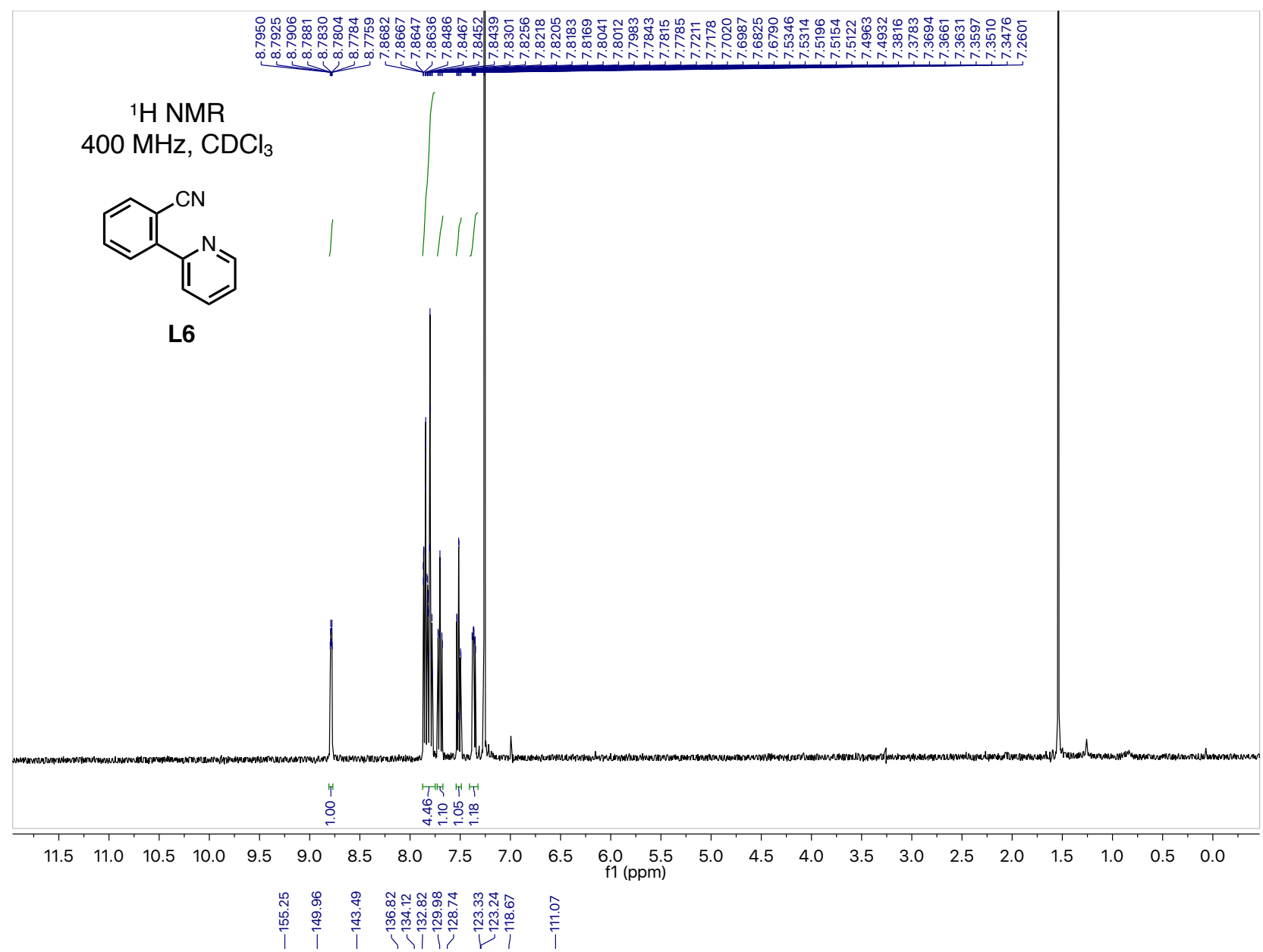

${ }^{13} \mathrm{C}\left\{{ }^{1} \mathrm{H}\right\}$ NMR

$100 \mathrm{MHz}, \mathrm{CDCl}_{3}$<smiles>N#Cc1ccccc1-c1ccccn1</smiles>

L6

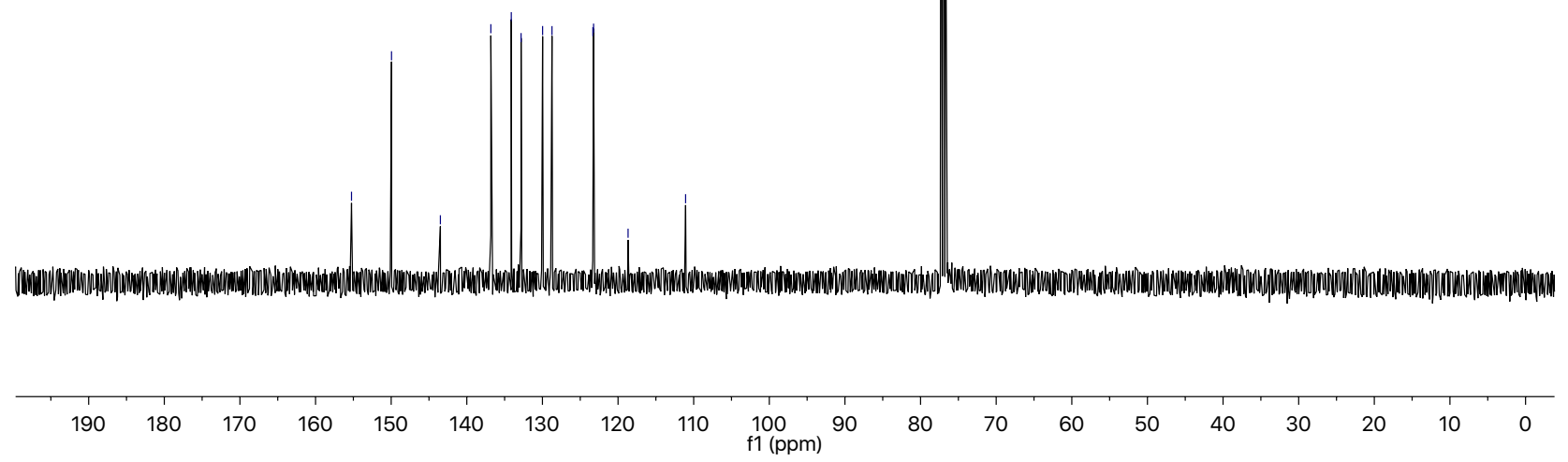




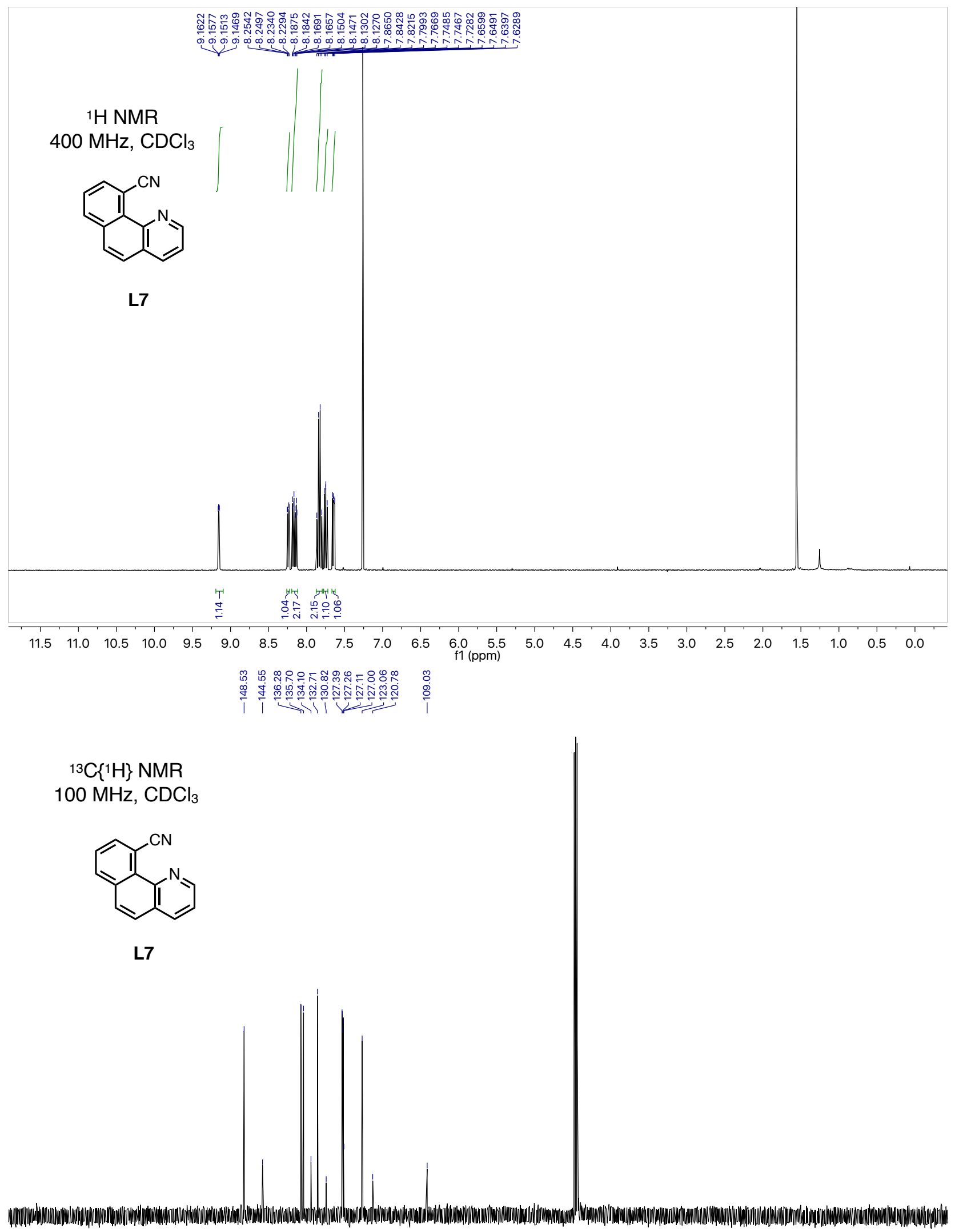

\begin{tabular}{|c|c|c|c|c|c|c|c|c|c|c|c|c|c|c|c|c|c|c|c|}
\hline 190 & 180 & 170 & 160 & 150 & 140 & 130 & 120 & 110 & $\begin{array}{c}100 \\
\mathrm{f} 1(\mathrm{ppm})\end{array}$ & 90 & 80 & 70 & 60 & 50 & 40 & 30 & 20 & 10 & 0 \\
\hline
\end{tabular}




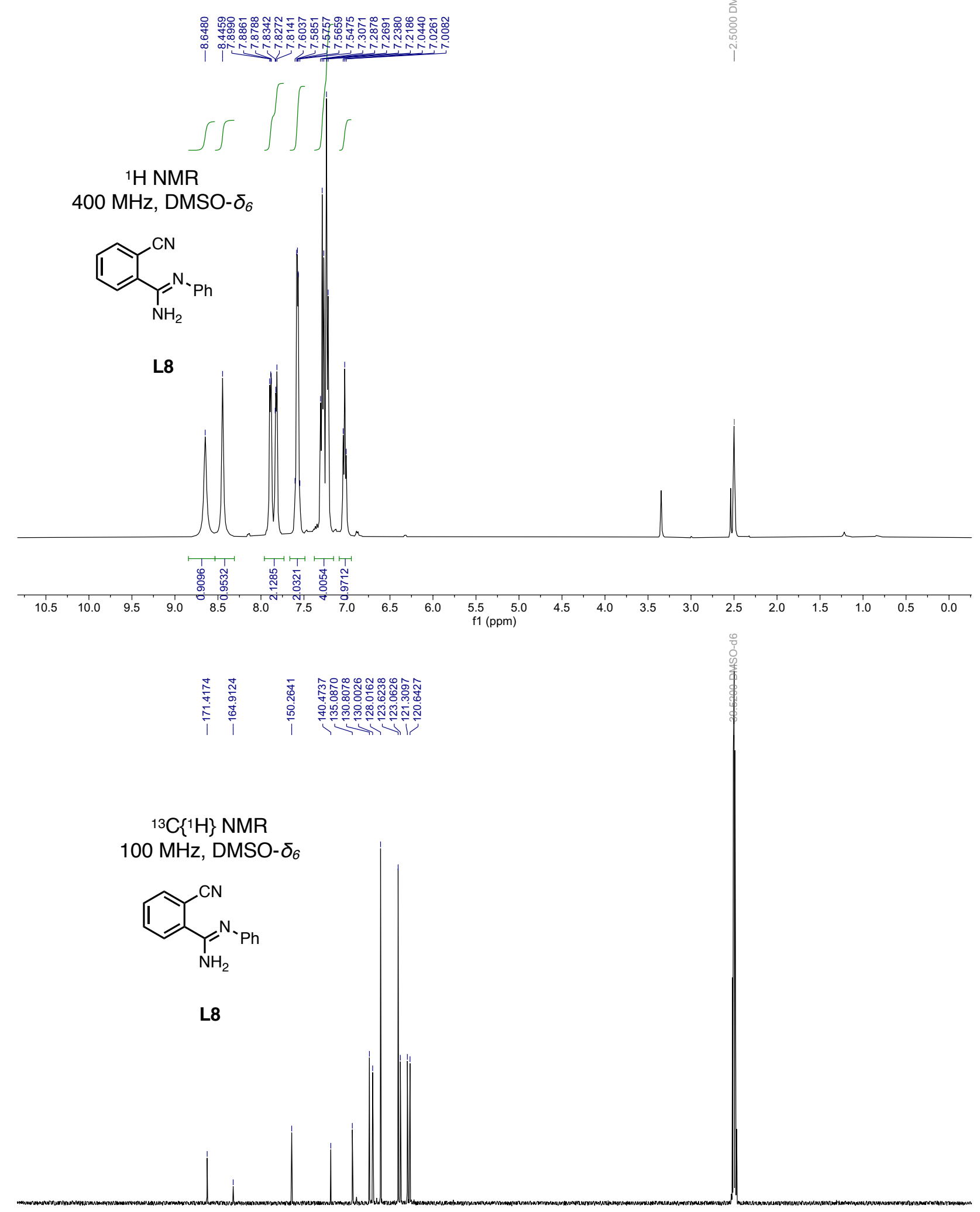

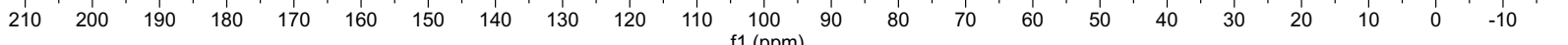



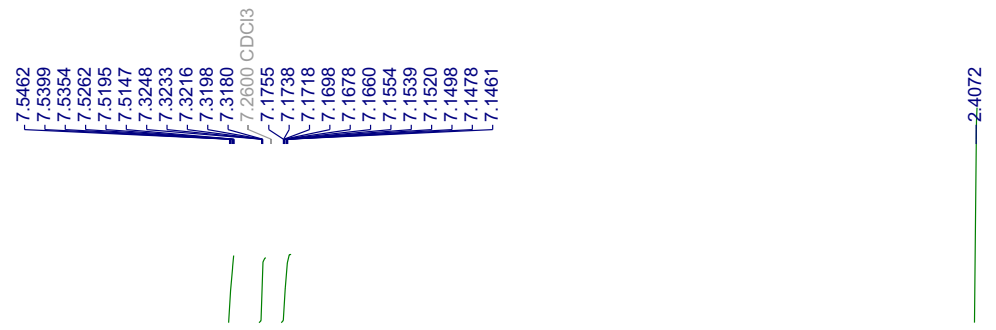

${ }^{1} \mathrm{H}$ NMR

$400 \mathrm{MHz}, \mathrm{CDCl}_{3}$<smiles>Cc1ccc(C#N)c(Cl)c1</smiles>

S7

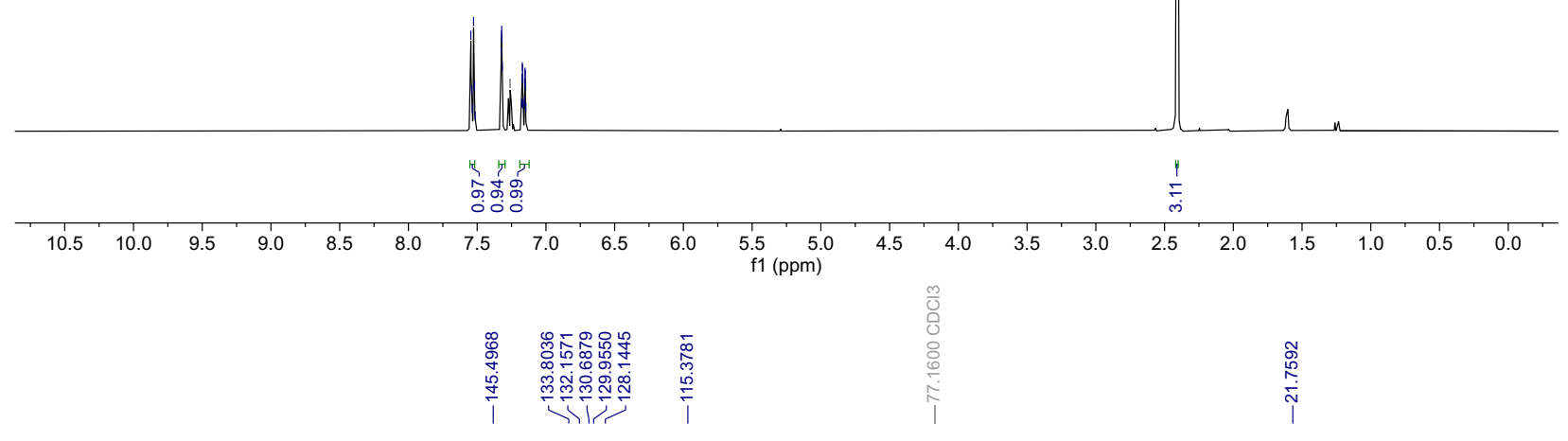

${ }^{13} \mathrm{C}\left\{{ }^{1} \mathrm{H}\right\}$ NMR

$100 \mathrm{MHz}, \mathrm{CDCl}_{3}$<smiles>Cc1ccc(C#N)c(Cl)c1</smiles>

S7

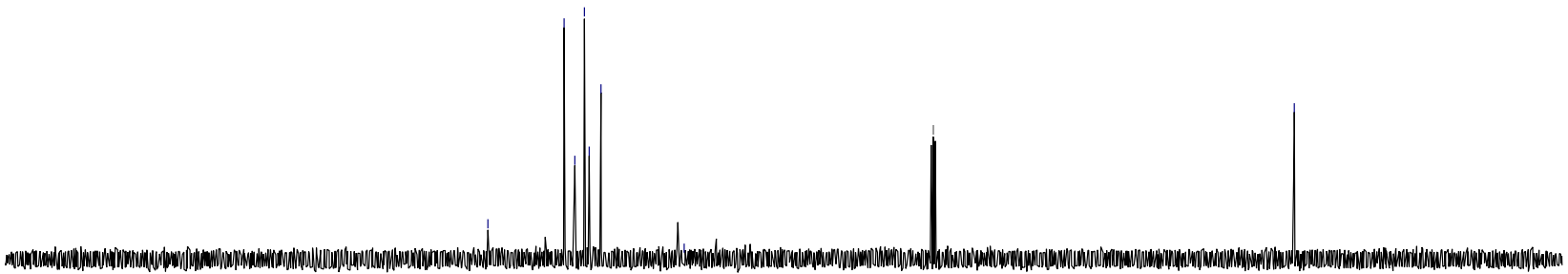

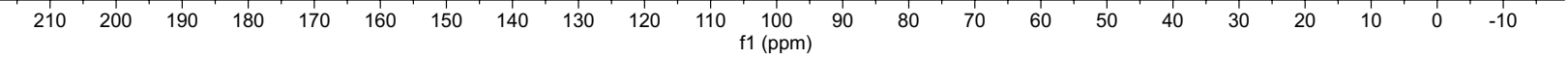




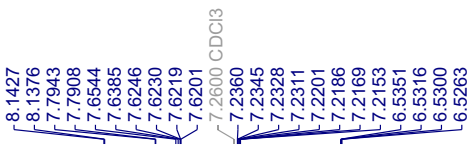

$1 \mathrm{H}$ NMR

$500 \mathrm{MHz}, \mathrm{CDCl}_{3}$
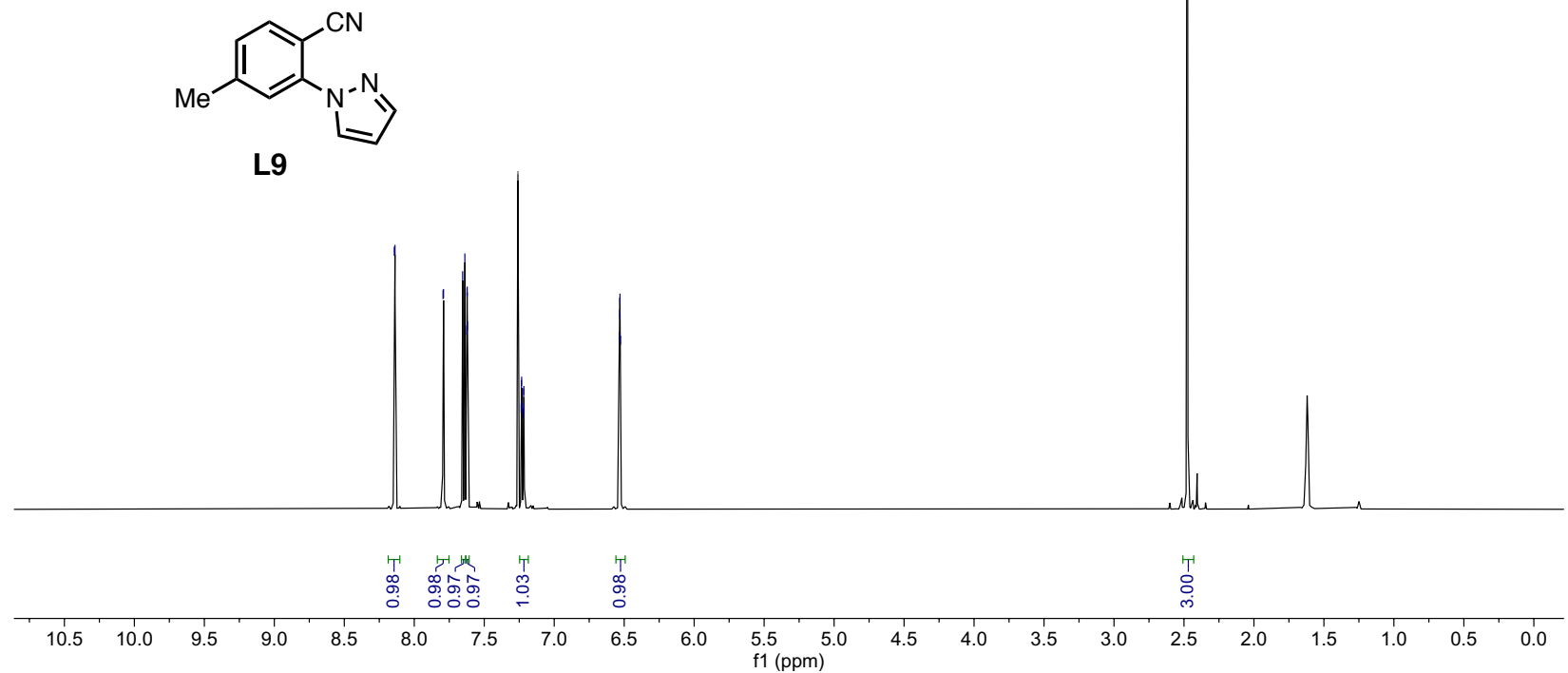

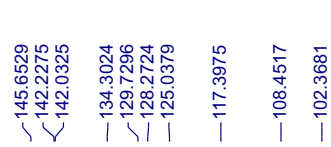

${ }^{13} \mathrm{C}\left\{{ }^{1} \mathrm{H}\right\} \mathrm{NMR}$

$125 \mathrm{MHz}, \mathrm{CDCl}_{3}$<smiles>Cc1ccc(C#N)c(-n2cccn2)c1</smiles>

L9

$\begin{array}{lllllllllllllllllllllll}\mid & 1 \\ 220 & 210 & 200 & 190 & 180 & 170 & 160 & 150 & 140 & 130 & 120 & \begin{array}{c}110 \\ \mathrm{f} 1(\mathrm{ppm})\end{array} & 90 & 80 & 70 & 60 & 50 & 40 & 30 & 20 & 10 & 0 & -10\end{array}$


$1 \mathrm{H}$ NMR

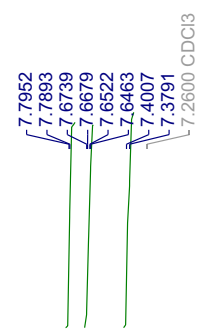

$400 \mathrm{MHz}, \mathrm{CDCl}_{3}$<smiles>N#Cc1cc(Br)ccc1Cl</smiles>

S8

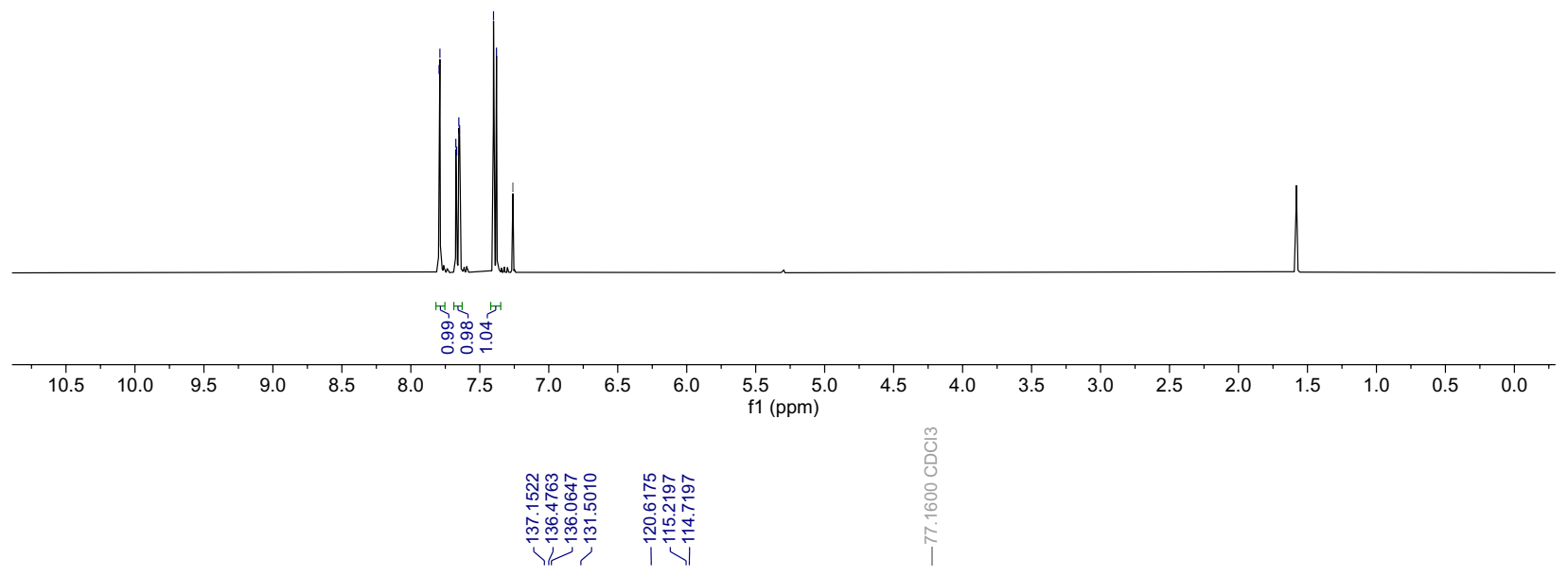

${ }^{13} \mathrm{C}\left\{{ }^{1} \mathrm{H}\right\} \mathrm{NMR}$

$100 \mathrm{MHz}, \mathrm{CDCl}_{3}$<smiles>N#Cc1cc(Br)ccc1Cl</smiles>

S8

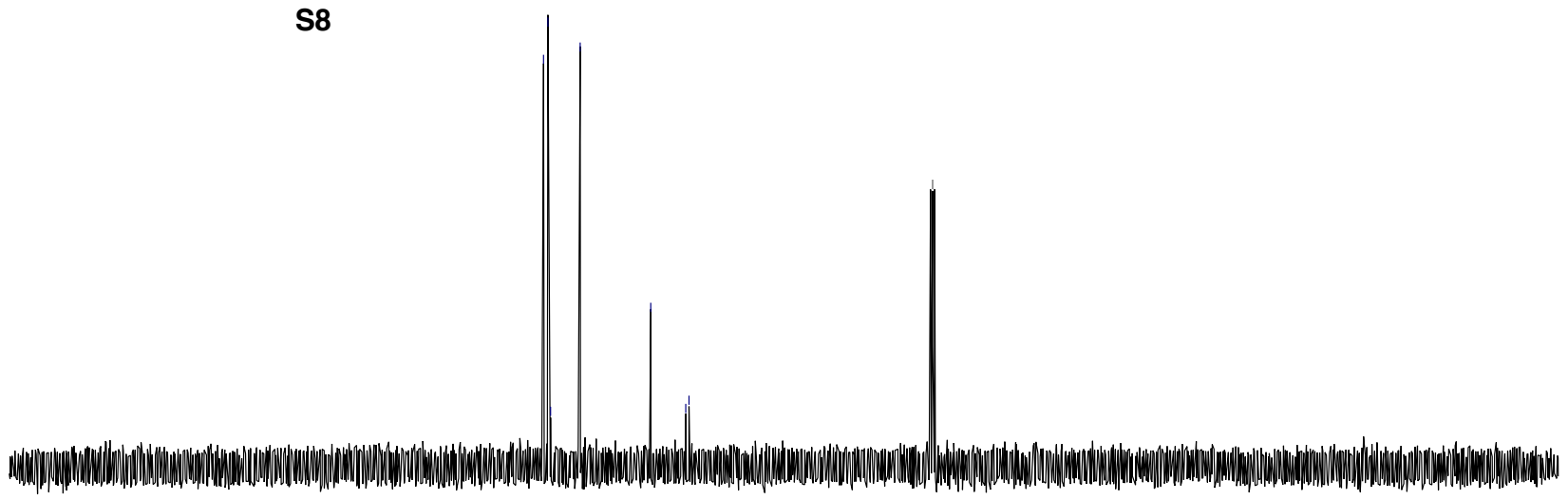

\begin{tabular}{|lllllllllllllllllllllll}
210 & 200 & 190 & 180 & 170 & 160 & 150 & 140 & 130 & 120 & 110 & $\begin{array}{c}100 \\
100\end{array}$ & 80 & 70 & 60 & 50 & 40 & 30 & 20 & 10 & 0 & -10 & 10
\end{tabular}




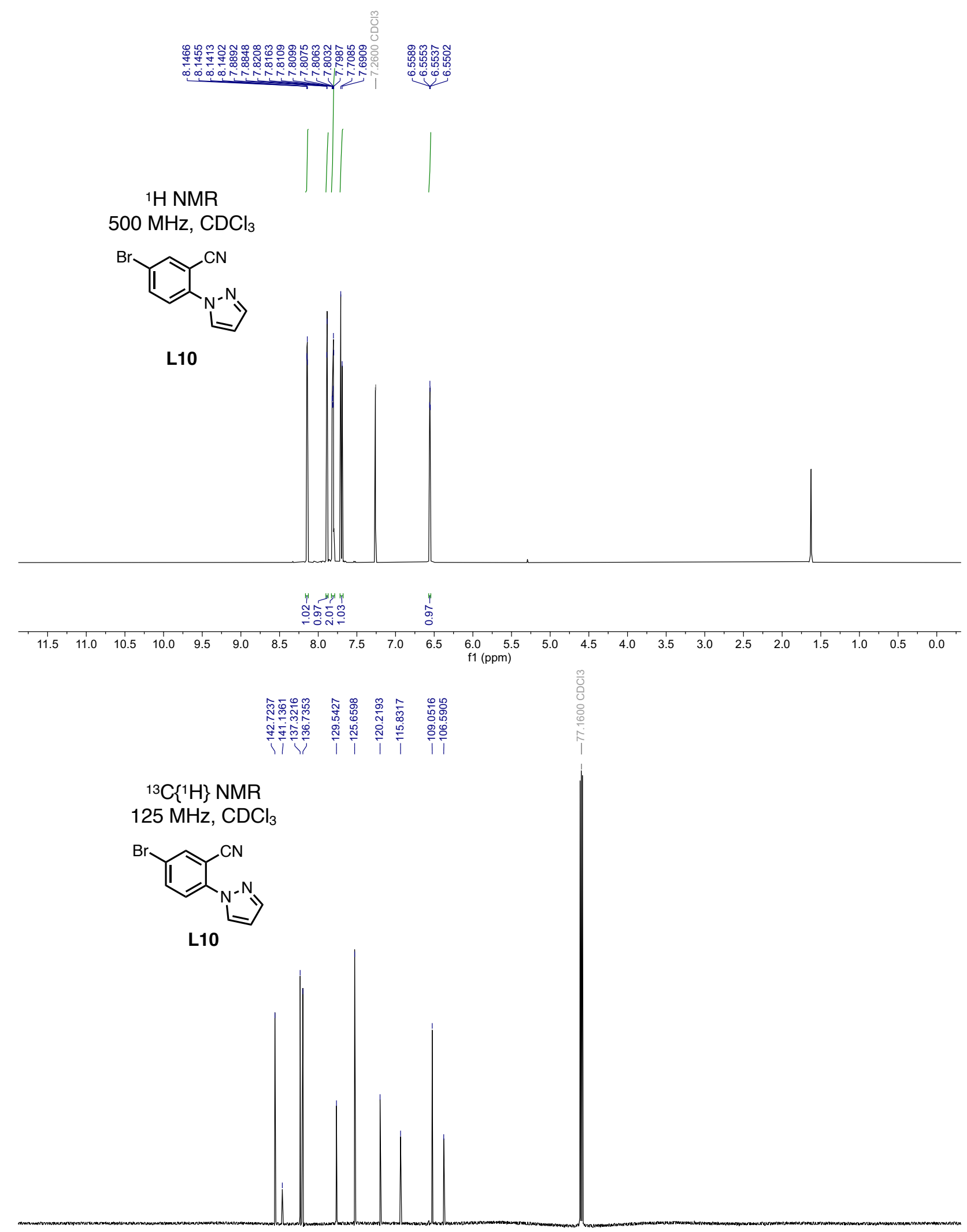

$\begin{array}{llllllllllllllllllll}190 & 180 & 170 & 160 & 150 & 140 & 130 & 120 & 110 & \begin{array}{l}100 \\ \mathrm{f} 1(\mathrm{ppm})\end{array} & 90 & 80 & 70 & 60 & 50 & 40 & 30 & 20 & 10 & 0\end{array}$




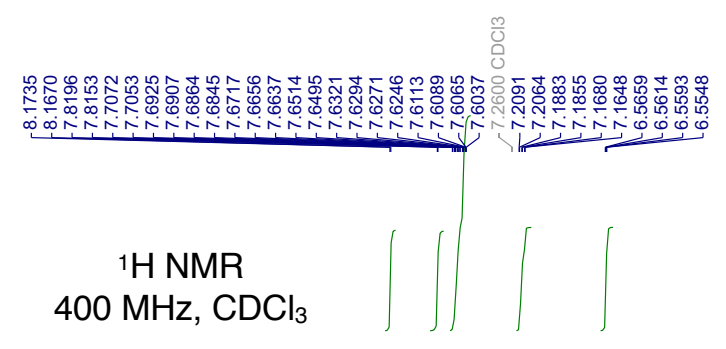<smiles>N#Cc1c(F)cccc1-n1cccn1</smiles>

L11

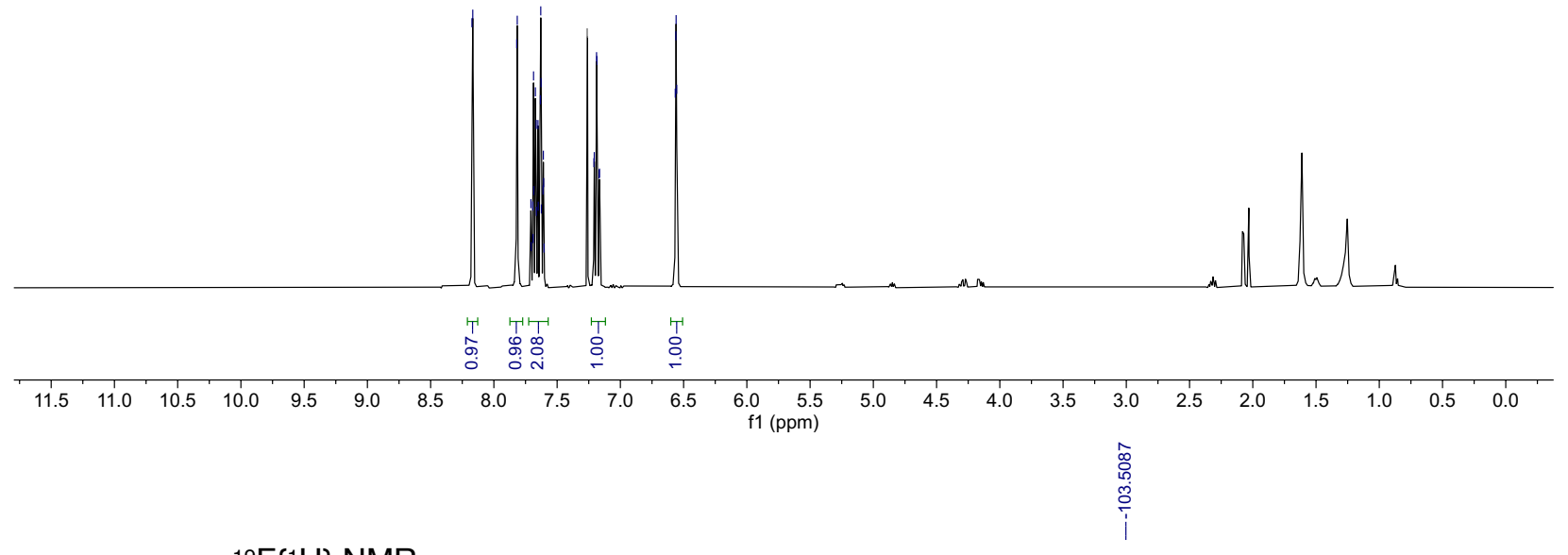

${ }^{19} \mathrm{~F}\left\{{ }^{1} \mathrm{H}\right\} \mathrm{NMR}$

$376 \mathrm{MHz}, \mathrm{CDCl}_{3}$<smiles>N#Cc1c(F)cccc1-n1cccn1</smiles>

L11

\begin{tabular}{llllllllllllllllllllll}
\hline 170 & 150 & 130 & 110 & 90 & 70 & 50 & 30 & 10 & -10 & -30 & -50 & -70 & -90 & -110 & -130 & -150 & -170 & -190 & -210
\end{tabular}




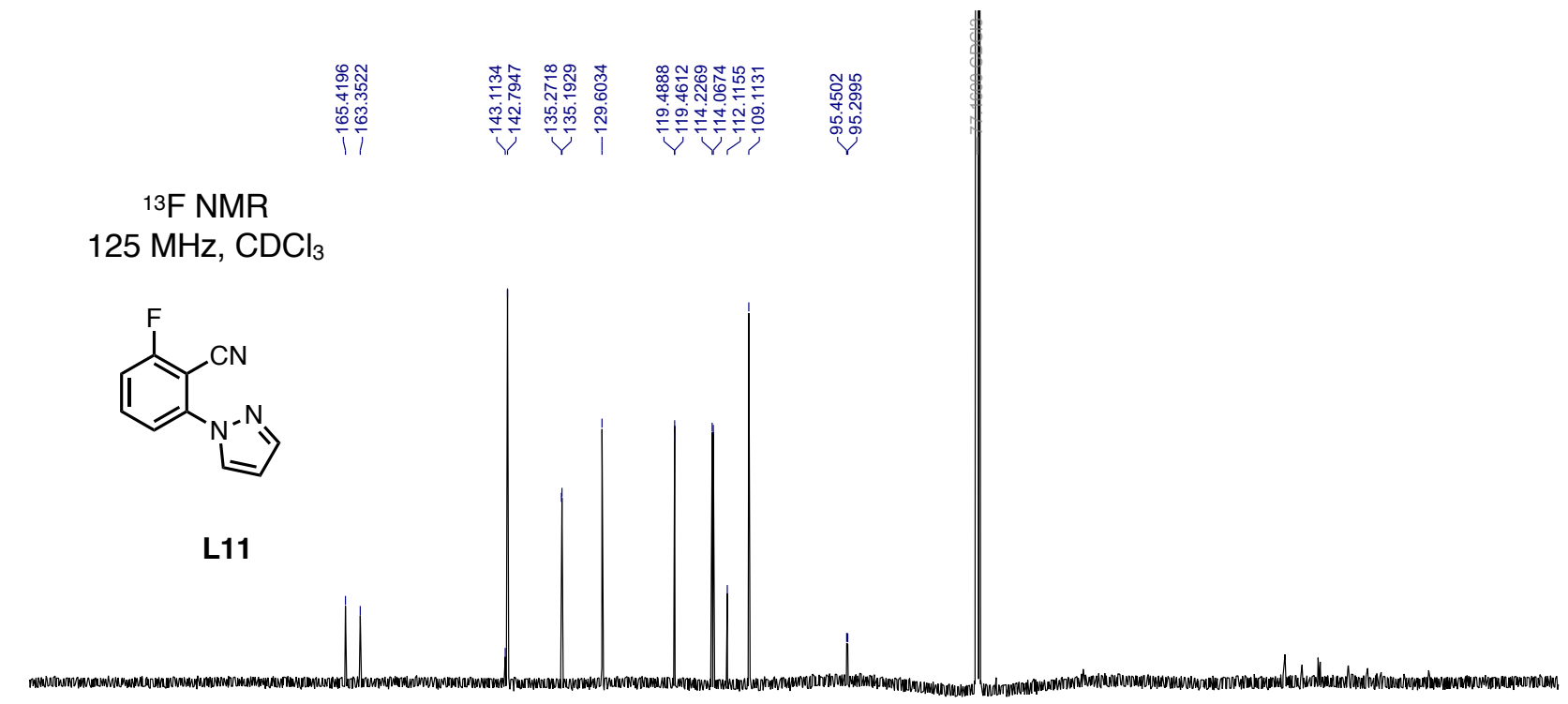

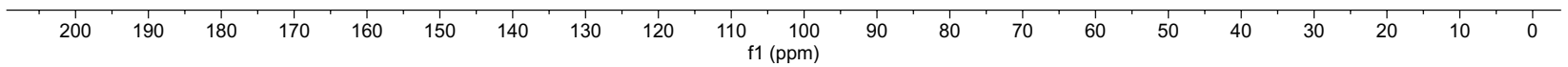



$400 \mathrm{MHz}, \mathrm{CDCl}_{3}$<smiles>N#Cc1ccccc1C1=N[C@H]2c3ccccc3C[C@H]2O1</smiles>
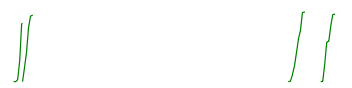

L12

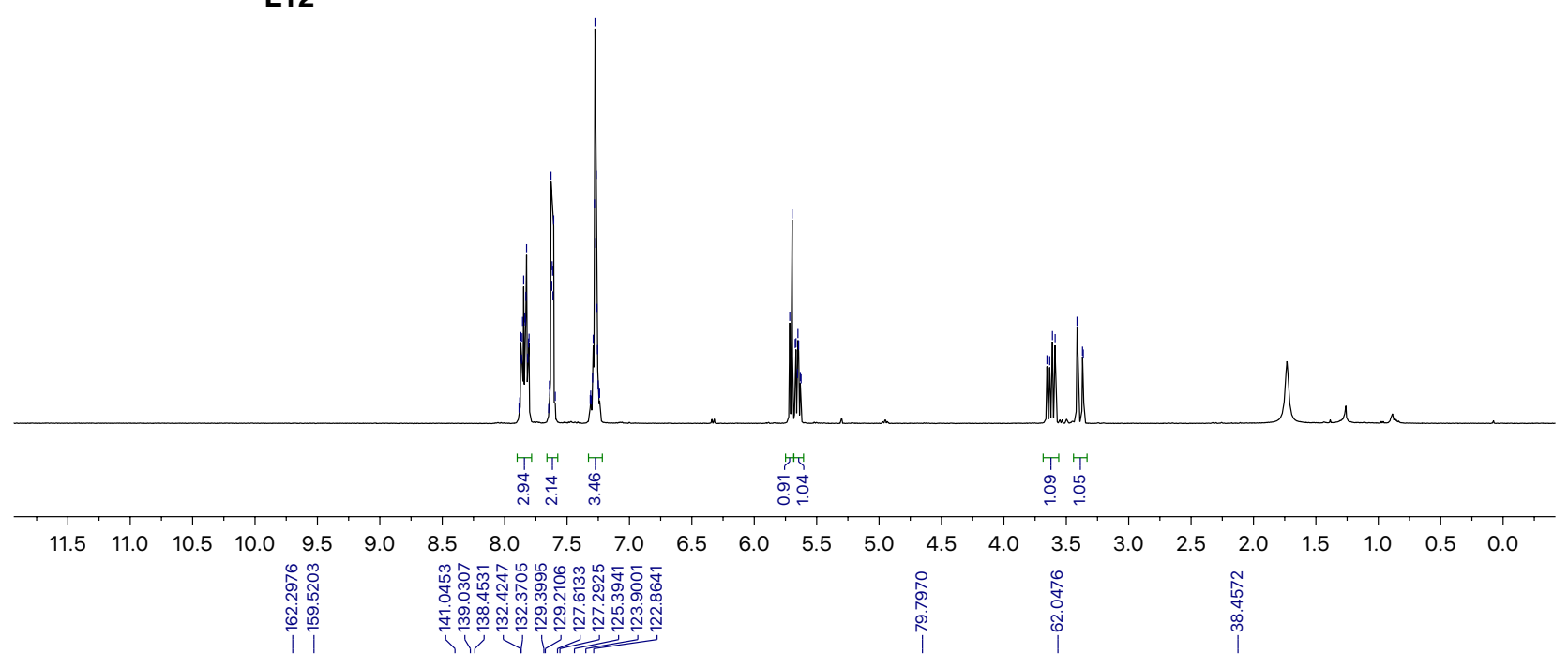

${ }^{13} \mathrm{C}\left\{{ }^{1} \mathrm{H}\right\} \mathrm{NMR}$

$100 \mathrm{MHz}, \mathrm{CDCl}_{3}$<smiles>N#Cc1ccccc1C1=N[C@H]2c3ccccc3C[C@H]2O1</smiles>

L12

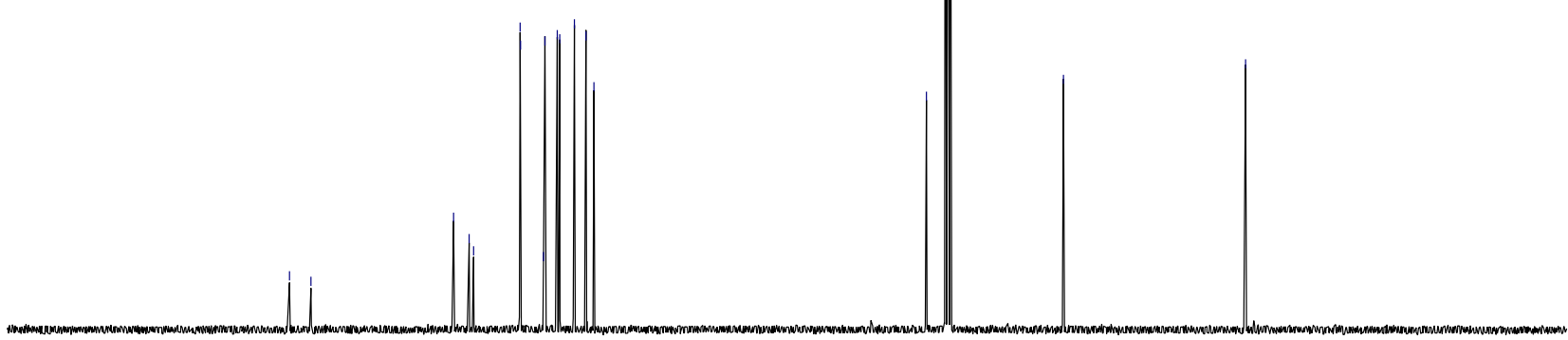


$1 \mathrm{H}$ NMR

$400 \mathrm{MHz}, \mathrm{CDCl}_{3}$<smiles>CC(C)C1COC(c2ccccc2Br)=N1</smiles>
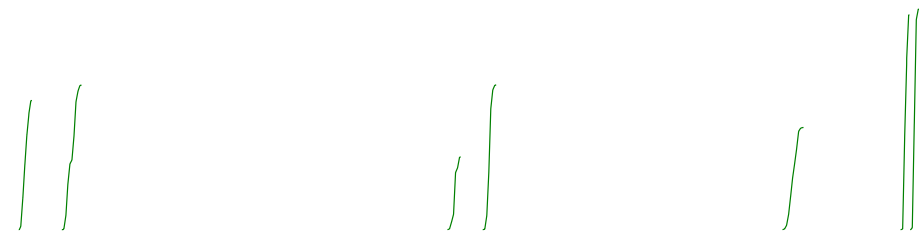

S9

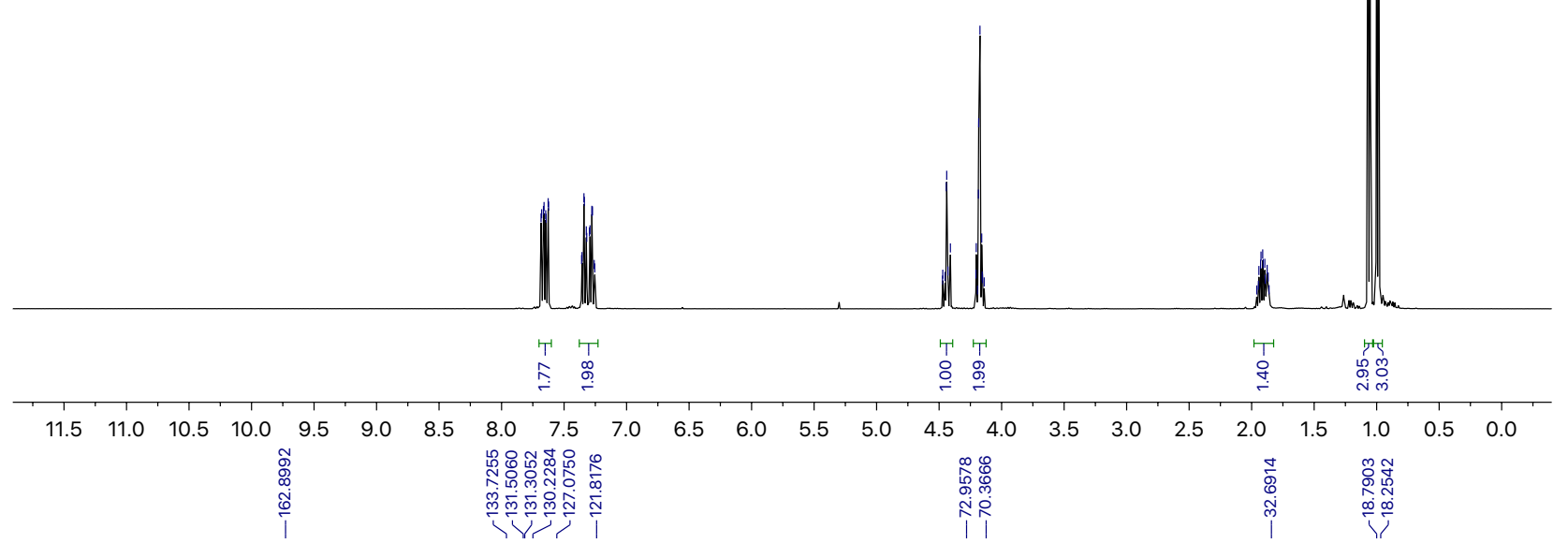

${ }^{13} \mathrm{C}\left\{{ }^{1} \mathrm{H}\right\} \mathrm{NMR}$

$100 \mathrm{MHz}, \mathrm{CDCl}_{3}$

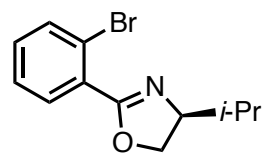

S9

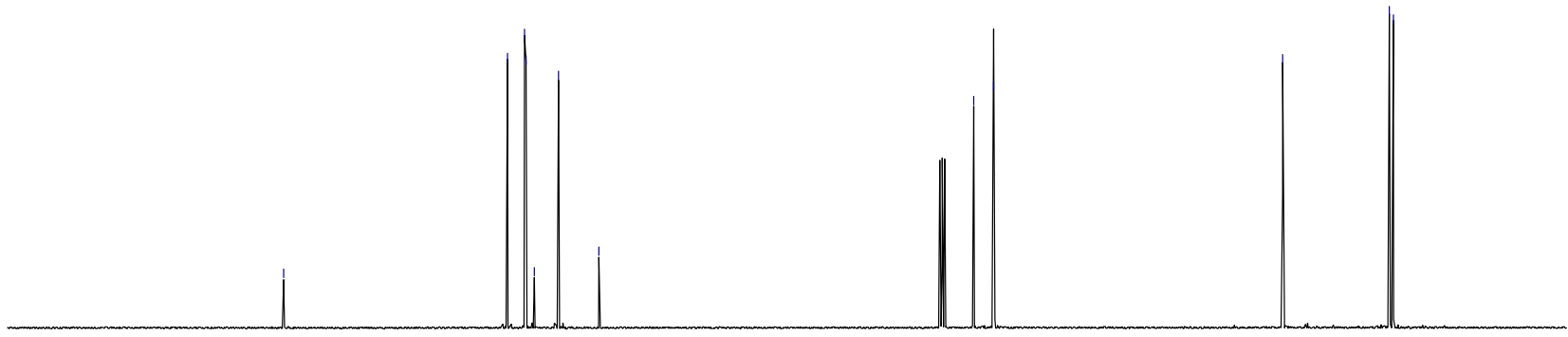


${ }^{1} \mathrm{H}$ NMR

$400 \mathrm{MHz}, \mathrm{CDCl}_{3}$<smiles>CCCC1COC(c2ccccc2C#N)=N1</smiles>

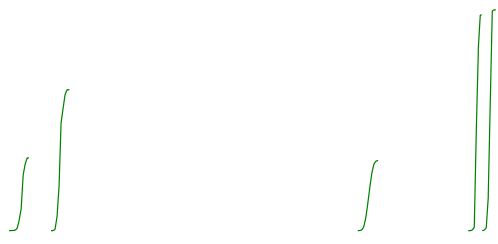

L13

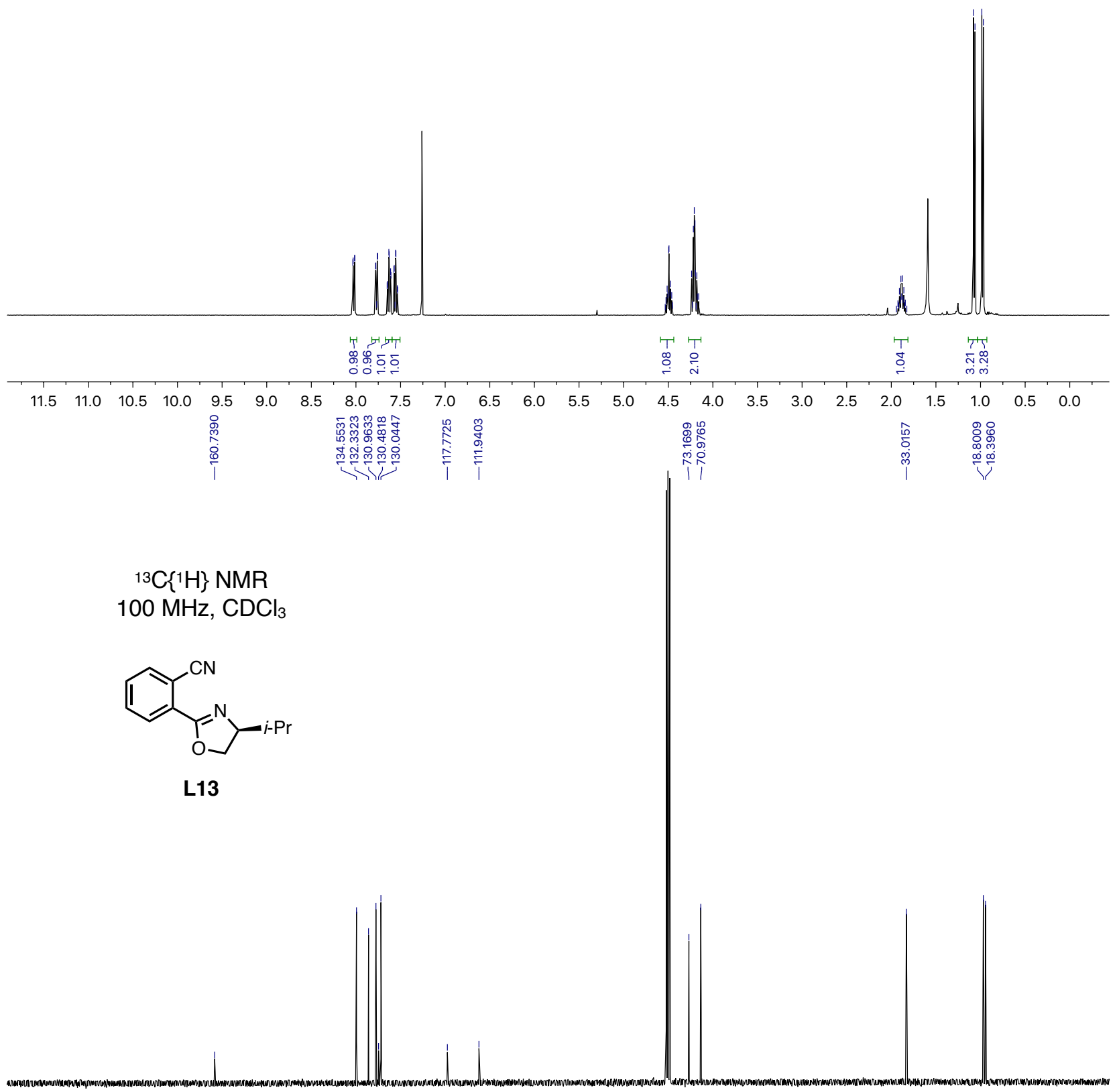




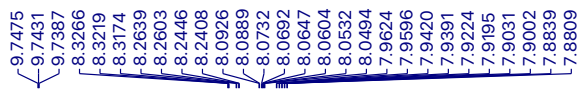

$1 \mathrm{H}$ NMR

$400 \mathrm{MHz}, \mathrm{DMSO}-d_{6}$<smiles></smiles>
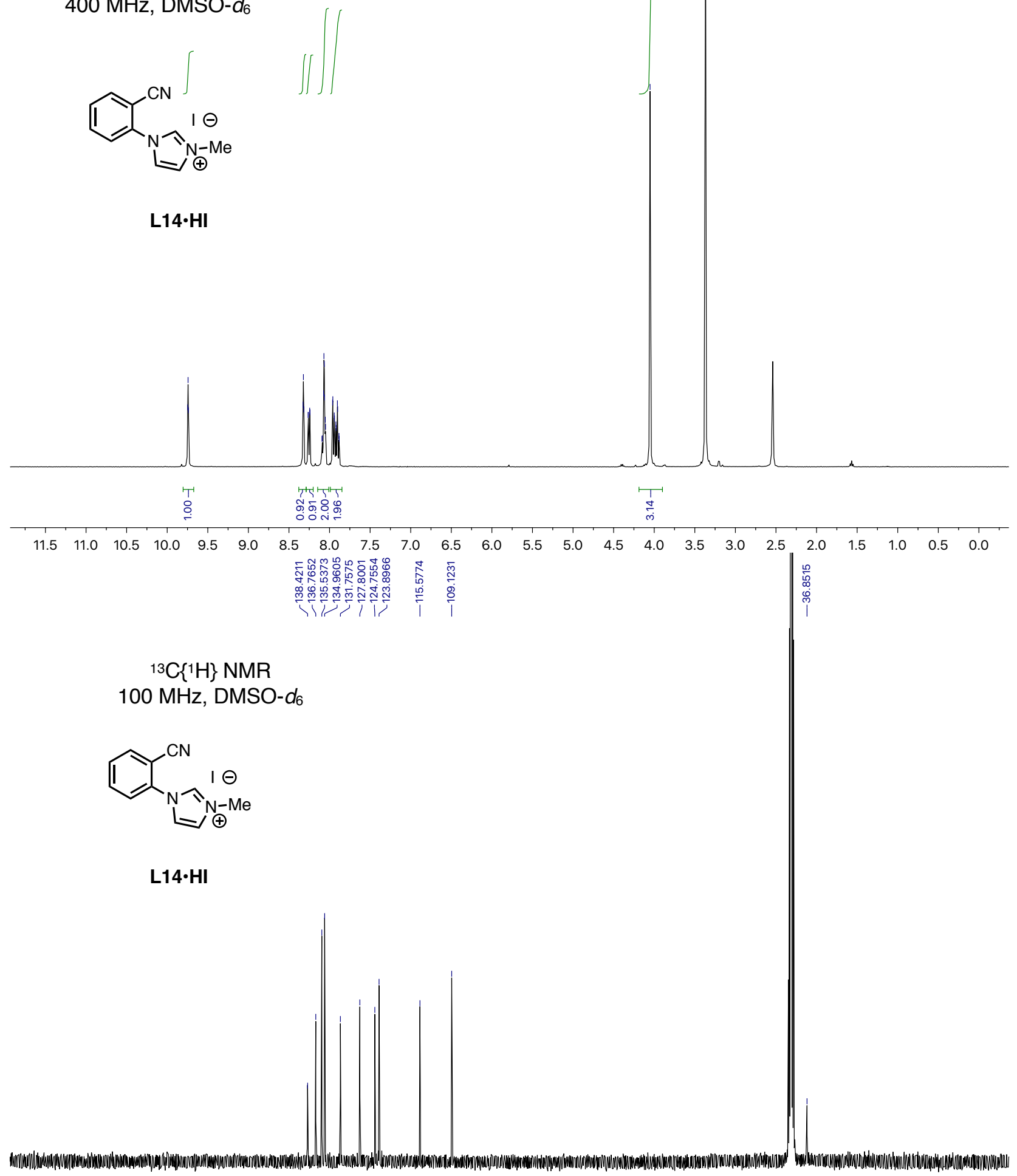

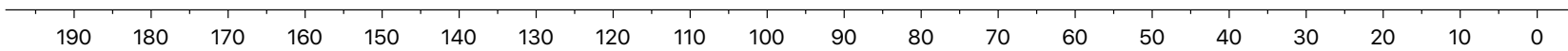



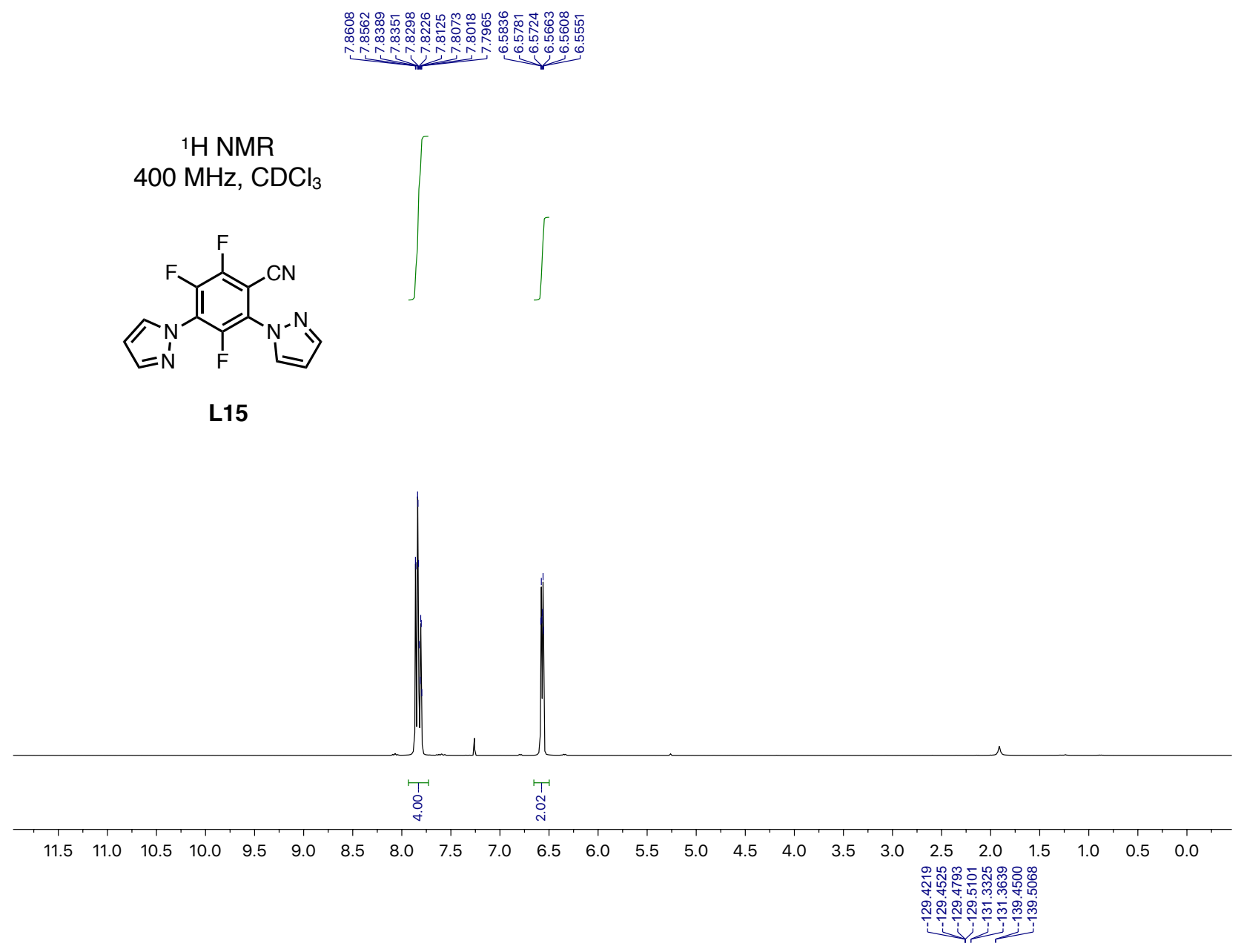

${ }^{19} \mathrm{~F}\left\{{ }^{1} \mathrm{H}\right\} \mathrm{NMR}$

$376 \mathrm{MHz}, \mathrm{CDCl}_{3}$

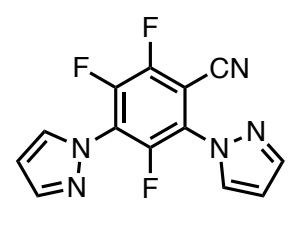

L15

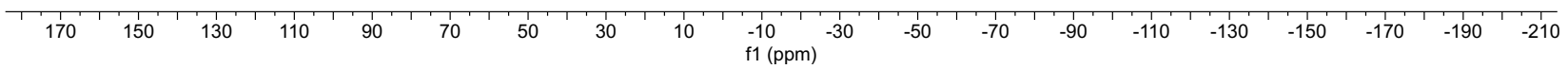




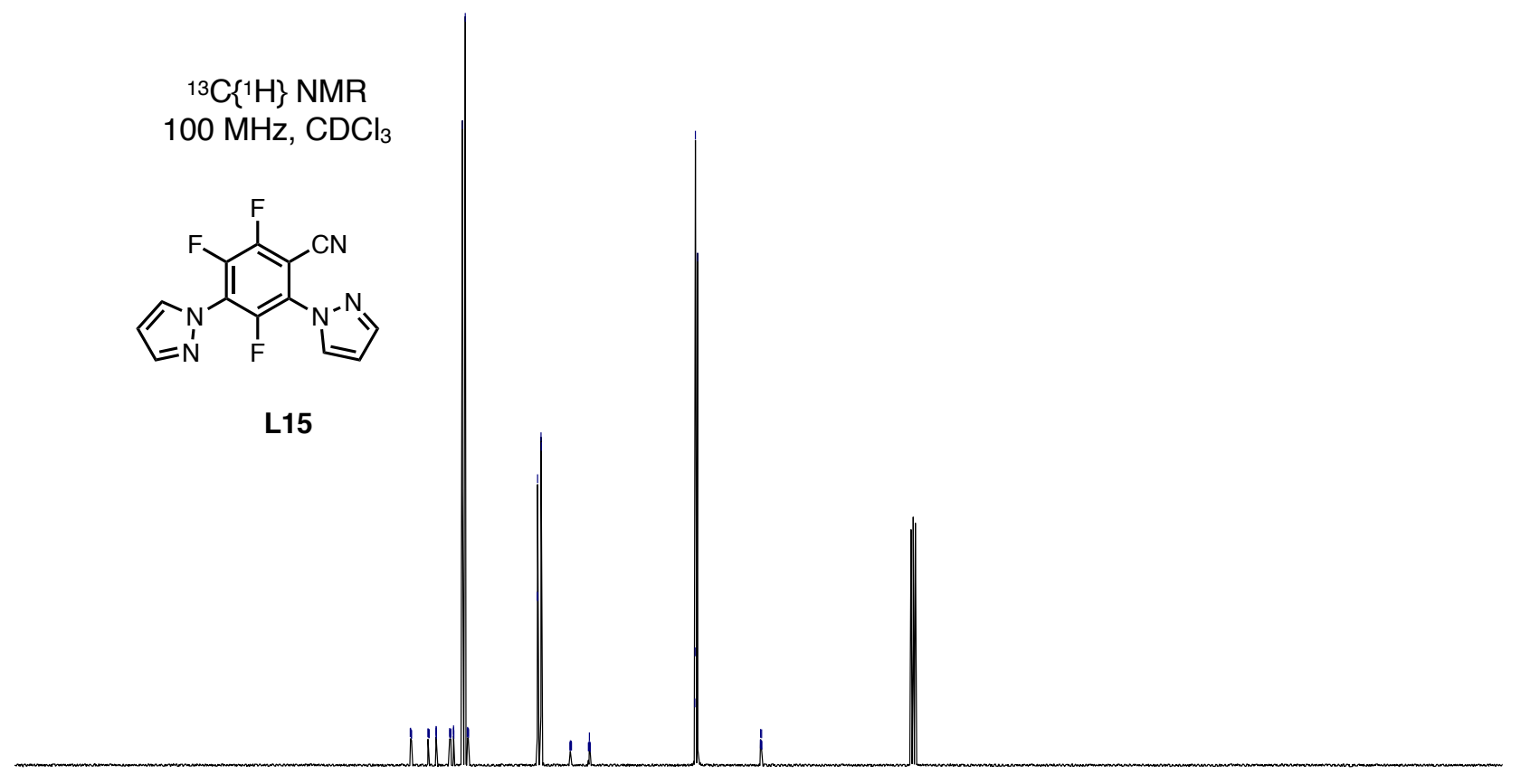

$\begin{array}{lllllllllllllllllllll}200 & 190 & 180 & 170 & 160 & 150 & 140 & 130 & 120 & 110 & \begin{array}{c}100 \\ \mathrm{f} 1(\mathrm{ppm})\end{array} & 90 & 80 & 70 & 60 & 50 & 40 & 30 & 20 & 10 & 0\end{array}$ 
$1 \mathrm{H}$ NMR

$400 \mathrm{MHz}, \mathrm{CDCl}_{3}$<smiles>CC(C)(C)c1ccccn1</smiles>

L16

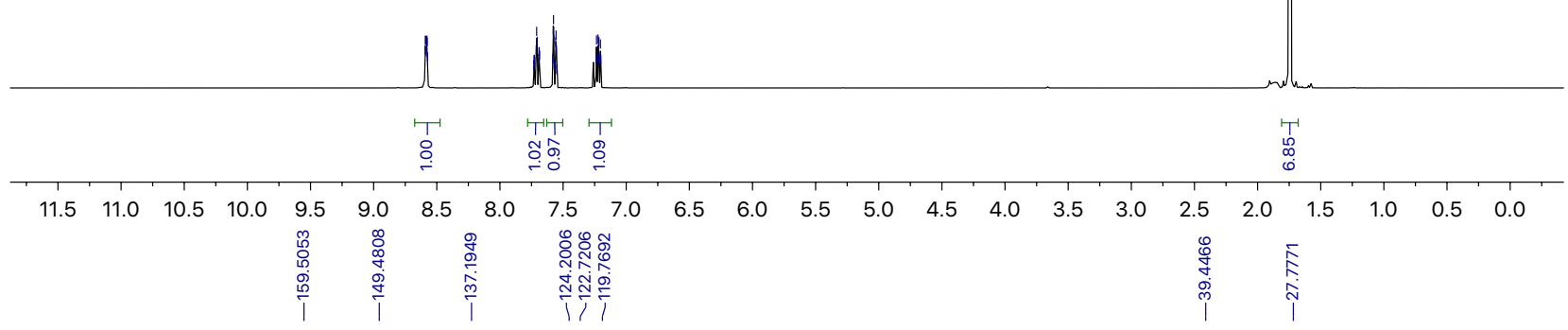

${ }^{13} \mathrm{C}\left\{{ }^{1} \mathrm{H}\right\} \mathrm{NMR}$

$100 \mathrm{MHz}, \mathrm{CDCl}_{3}$

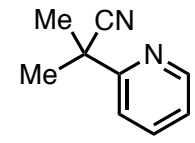

L16

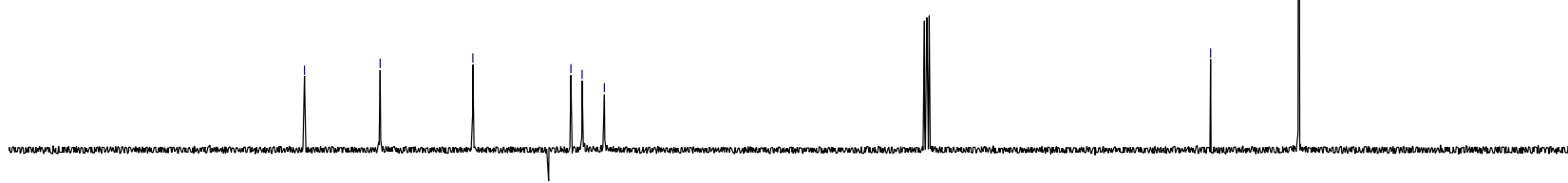


$1 \mathrm{H}$ NMR

$400 \mathrm{MHz}, \mathrm{CDCl}_{3}$<smiles>N#CC(Br)(Br)C1=NC(Br)CO1</smiles>
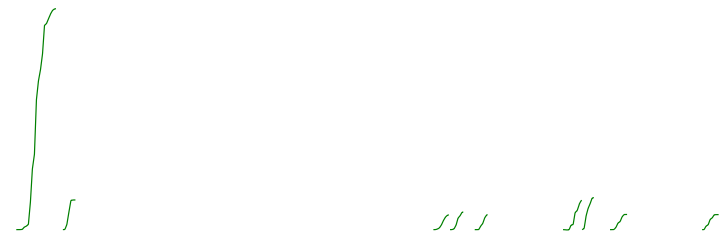

L17

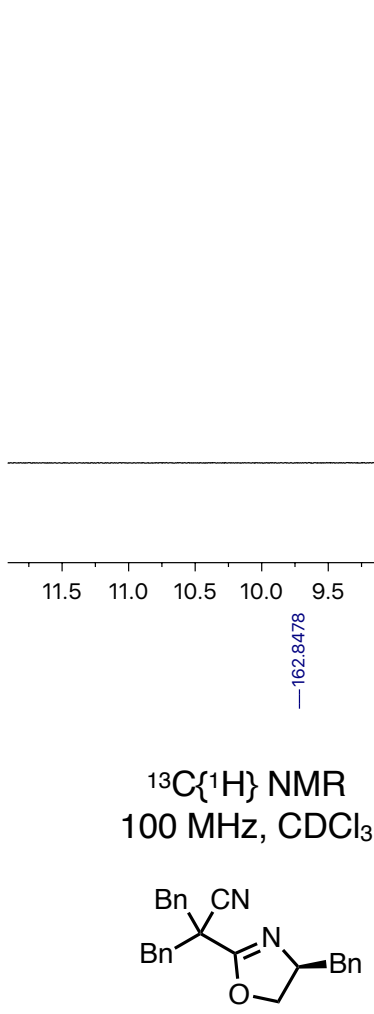

L17

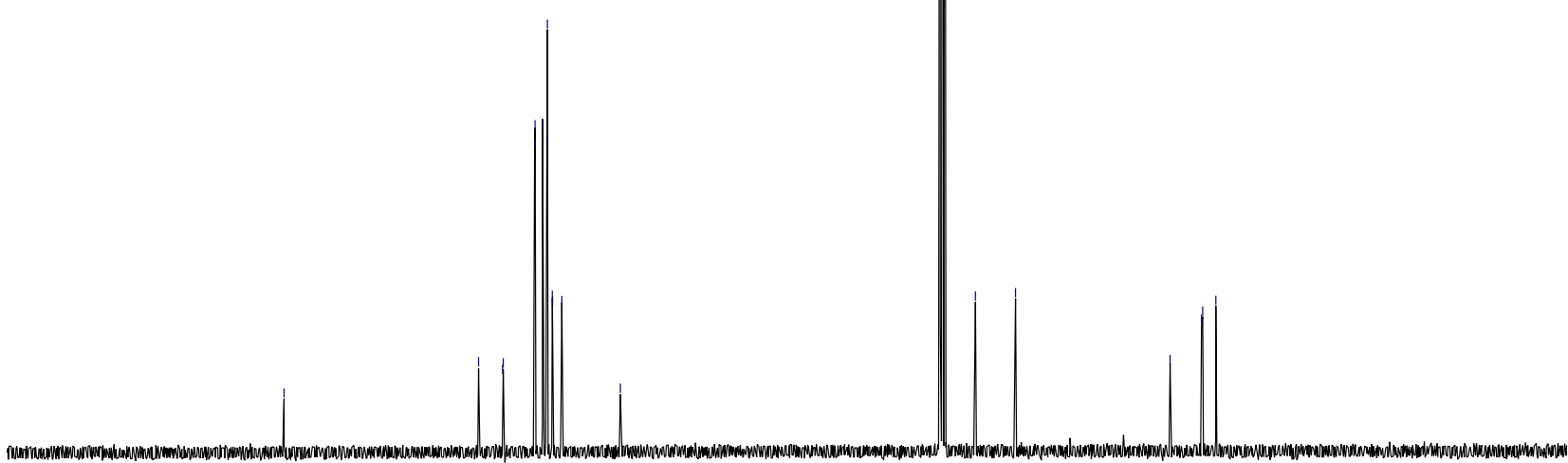




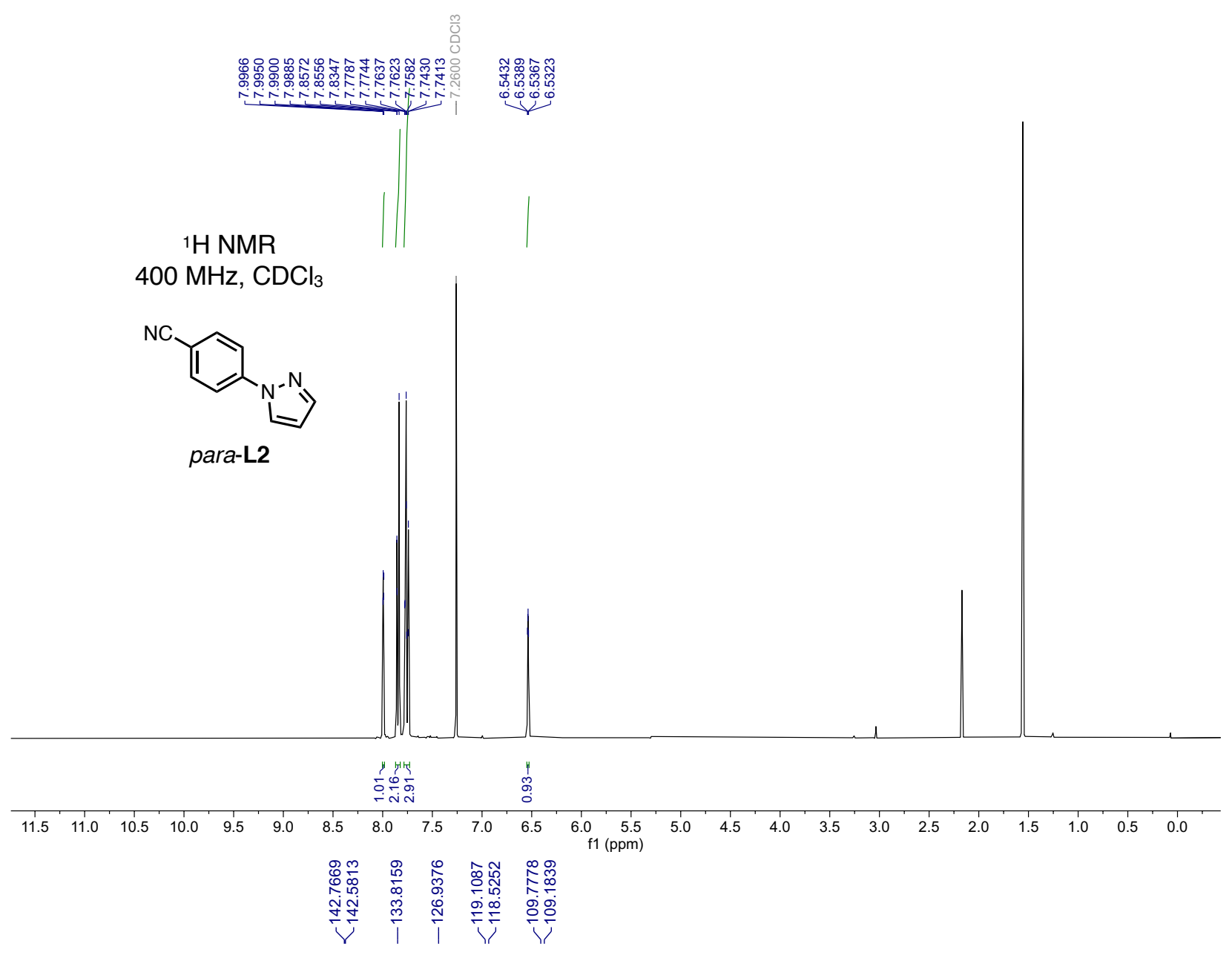

${ }^{13} \mathrm{C}\left\{{ }^{1} \mathrm{H}\right\}$ NMR

$100 \mathrm{MHz}, \mathrm{CDCl}_{3}$

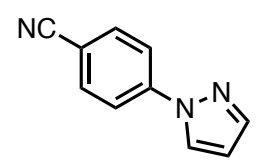

para-L2

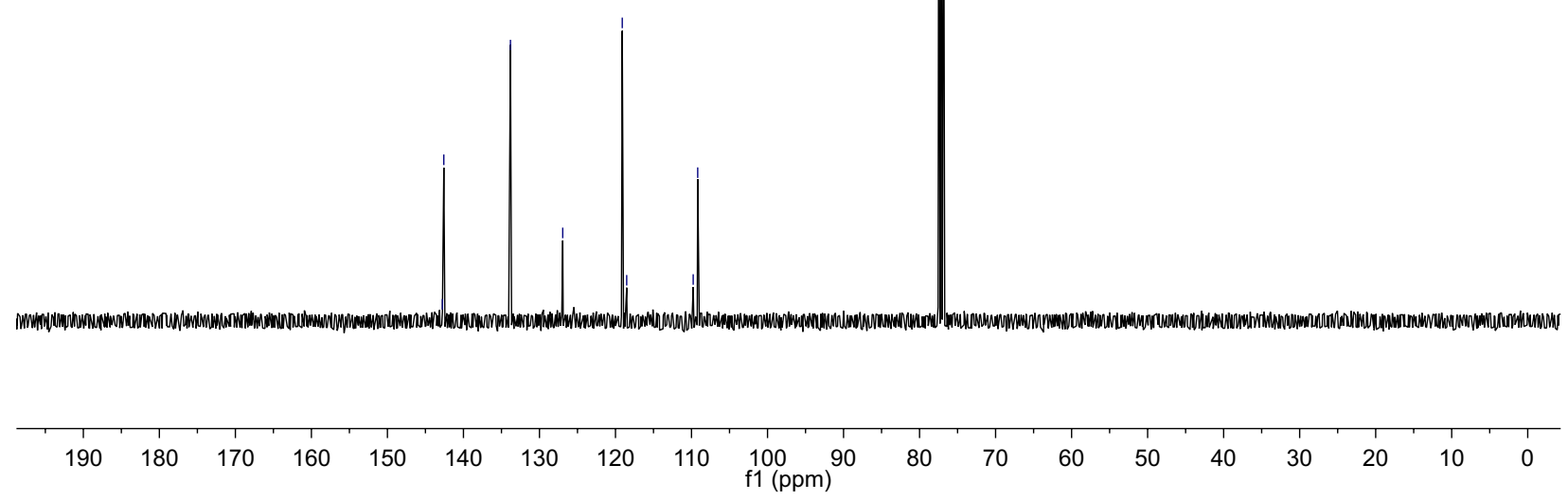




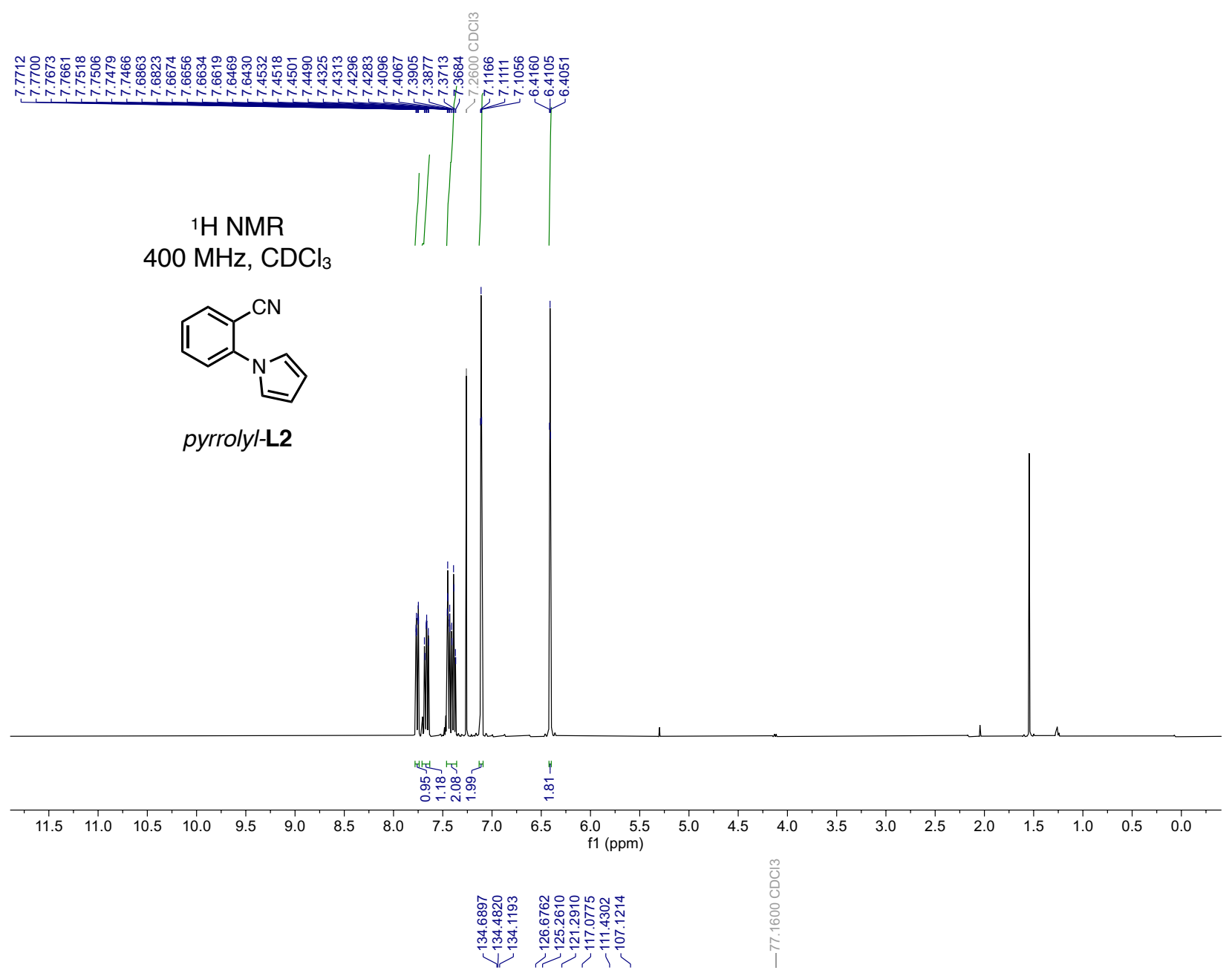

${ }^{13} \mathrm{C}\left\{{ }^{1} \mathrm{H}\right\} \mathrm{NMR}$

$100 \mathrm{MHz}, \mathrm{CDCl}_{3}$<smiles>N#Cc1ccccc1-n1cccc1</smiles>

pyrrolyl-L2

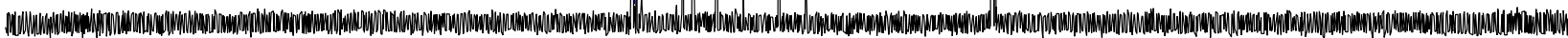

$\begin{array}{llllllllllllllllllllllllll}230 & 220 & 210 & 200 & 190 & 180 & 170 & 160 & 150 & 140 & 130 & 120 & 110 & 100 & 90 & 80 & 70 & 60 & 50 & 40 & 30 & 20 & 10 & 0 & -10\end{array}$ 


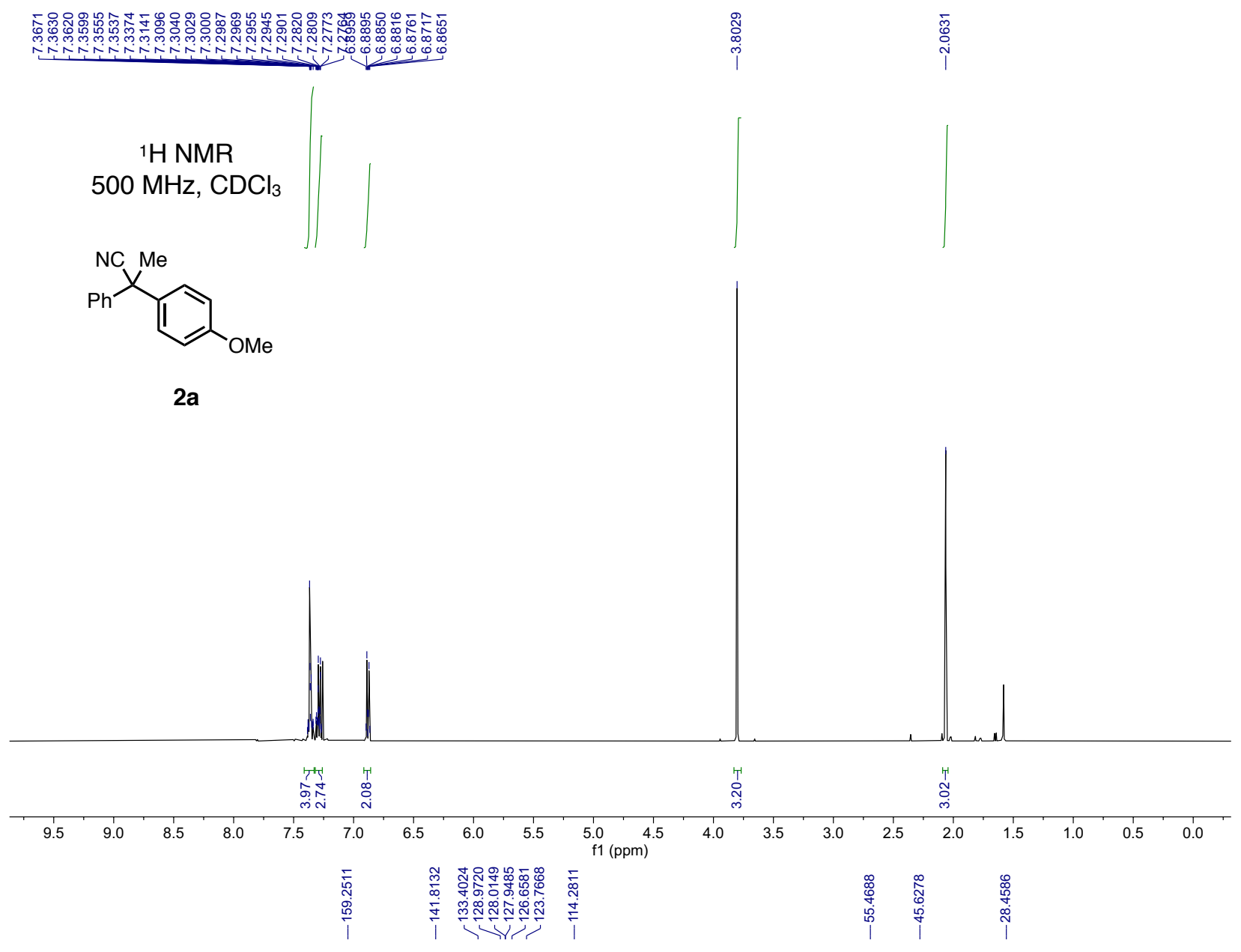

${ }^{13} \mathrm{C}\left\{{ }^{1} \mathrm{H}\right\}$ NMR

$125 \mathrm{MHz}, \mathrm{CDCl}_{3}$

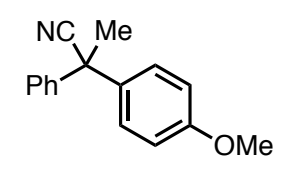

2a

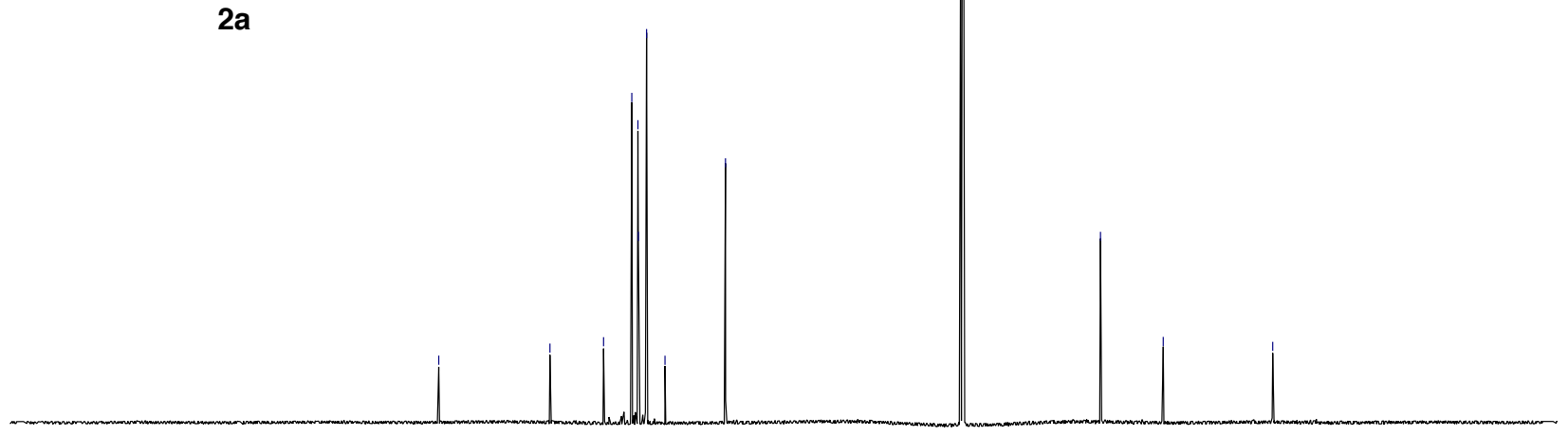

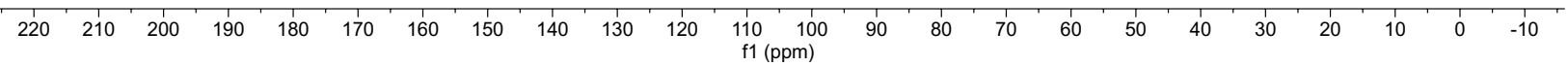




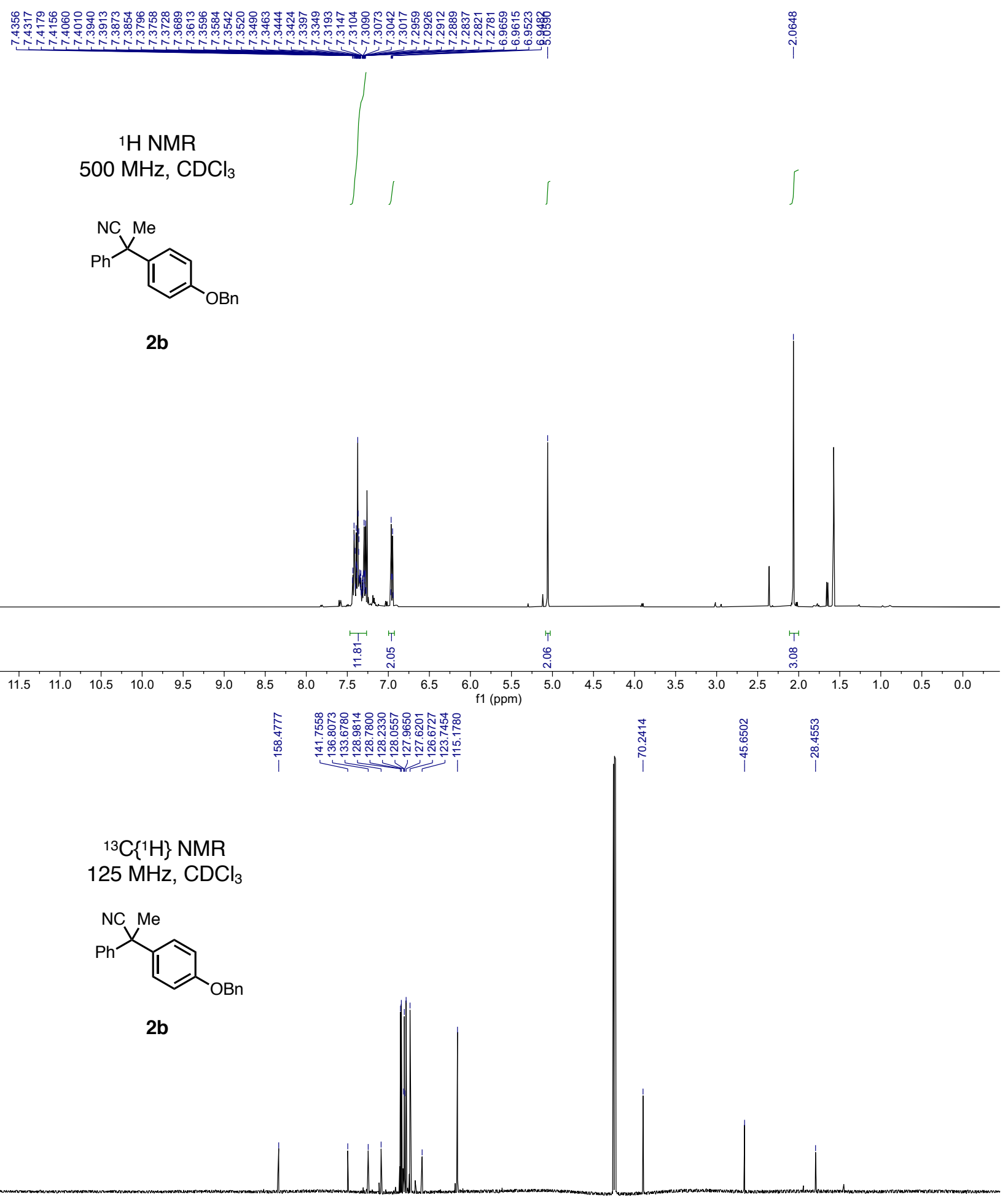

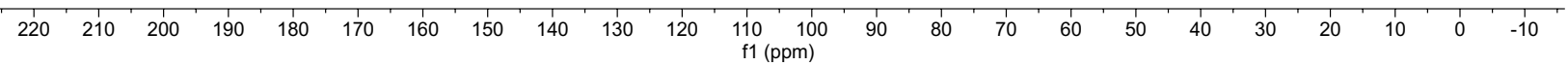


$500 \mathrm{MHz}, \mathrm{CDCl}_{3}$<smiles>CC(C)(c1ccccc1)c1ccc(OP)cc1</smiles>

2c

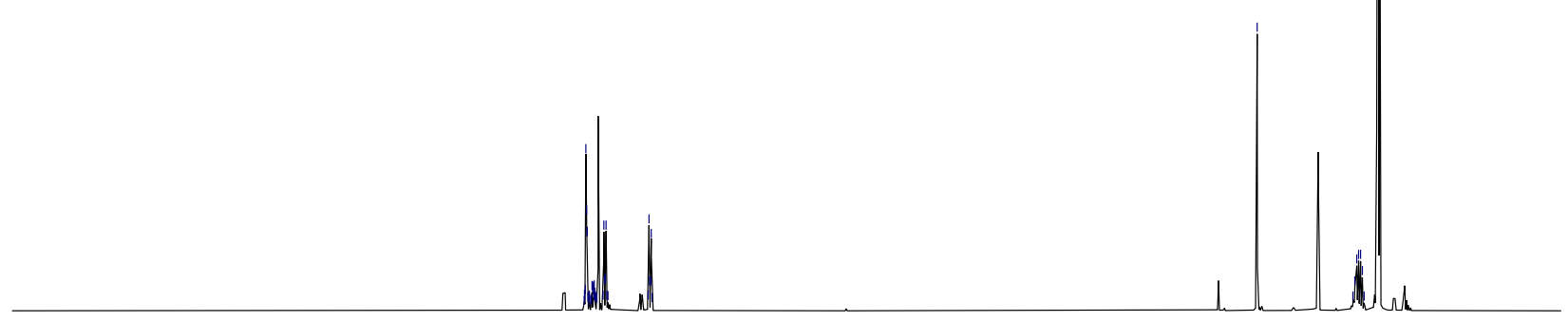

${ }^{13} \mathrm{C}\left\{{ }^{1} \mathrm{H}\right\} \mathrm{NMR}$

$125 \mathrm{MHz}, \mathrm{CDCl}_{3}$

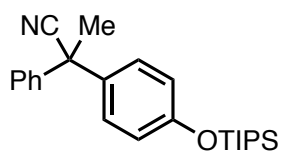

2c

- $\frac{1}{2}=$

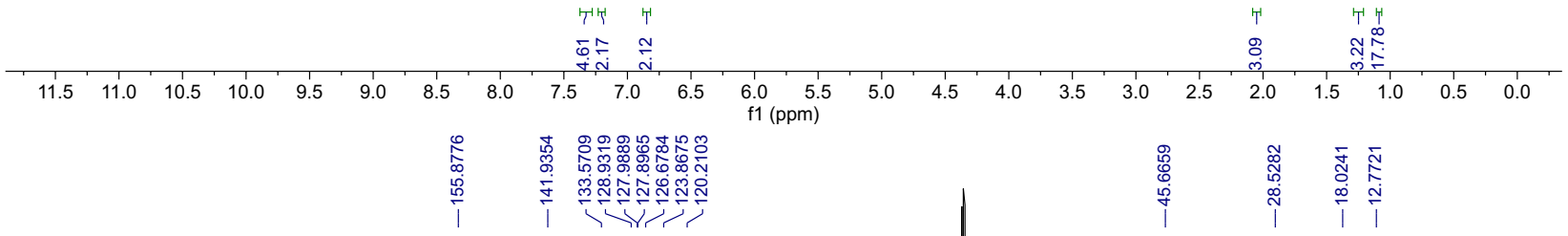

$\begin{array}{llllllllllll}220 & 210 & 200 & 190 & 180 & 170 & 160 & 150 & 140 & 130 & 120 & \begin{array}{r}110 \\ \mathrm{f} 1\end{array}(\mathrm{ppm})\end{array}$ 
${ }^{1} \mathrm{H}$ NMR

$400 \mathrm{MHz}, \mathrm{CDCl}_{3}$<smiles>CC(C)(c1ccccc1)c1ccc([N+](=O)[O-])cc1</smiles>

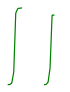

2d

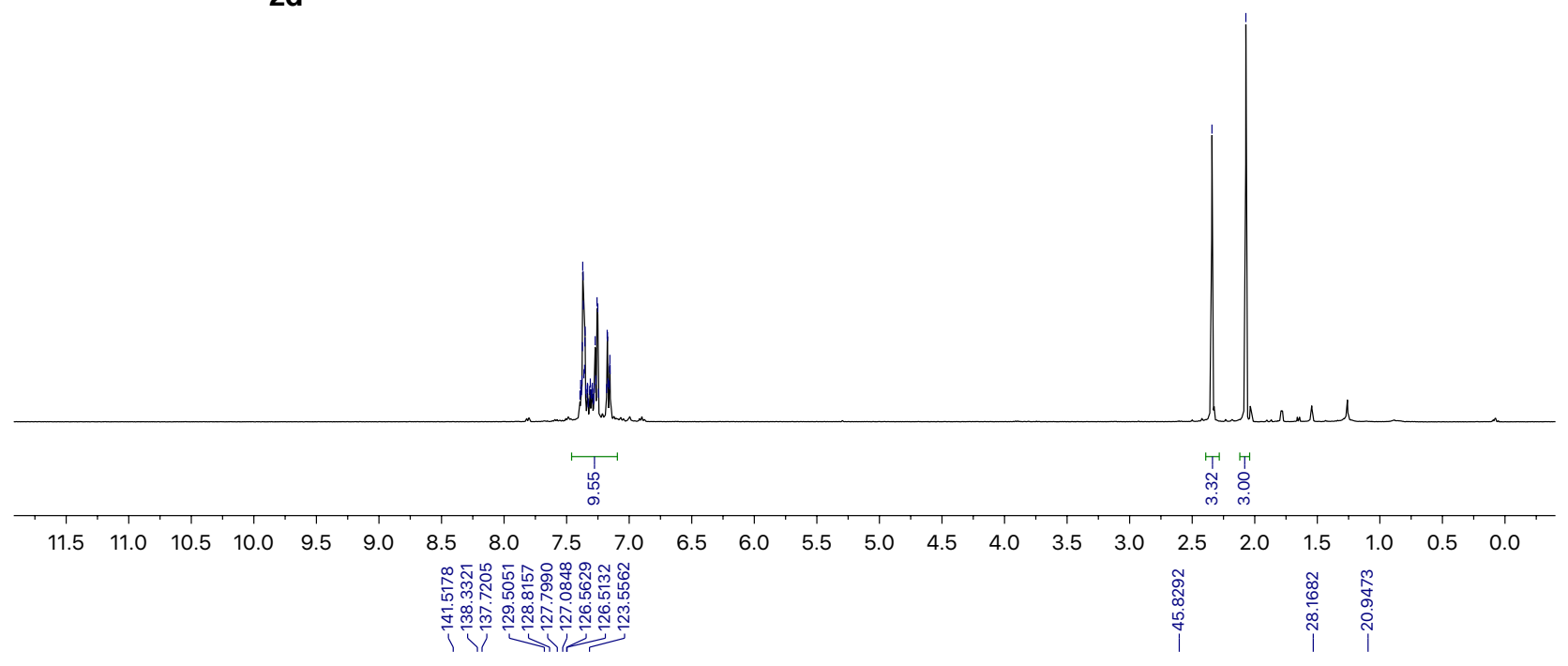

${ }^{13} \mathrm{C}\left\{{ }^{1} \mathrm{H}\right\}$ NMR

$100 \mathrm{MHz}, \mathrm{CDCl}_{3}$<smiles>Cc1ccc(C(C)(C)c2ccccc2)cc1</smiles>

2d

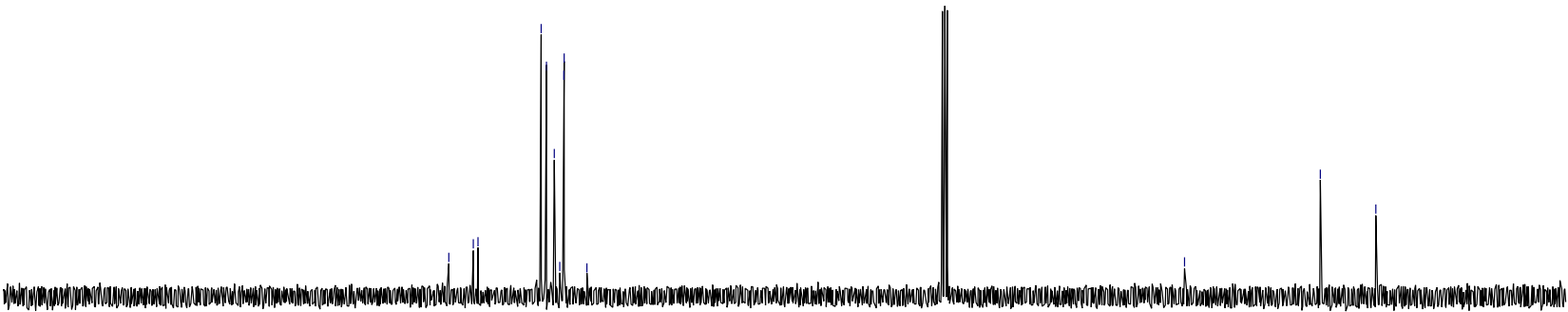

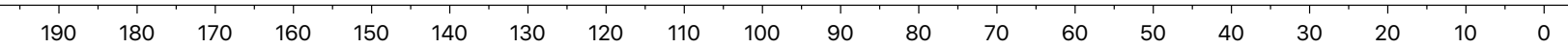




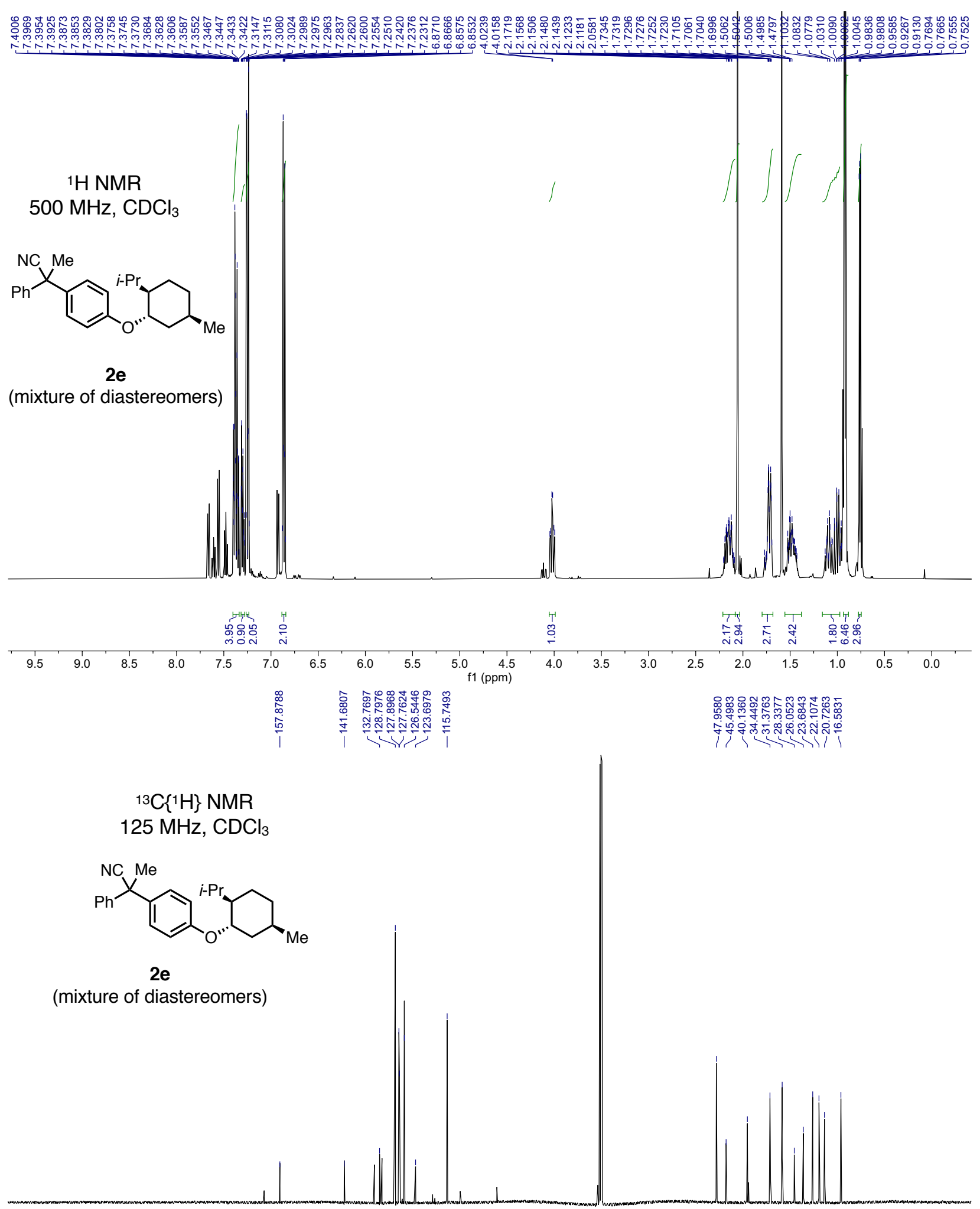

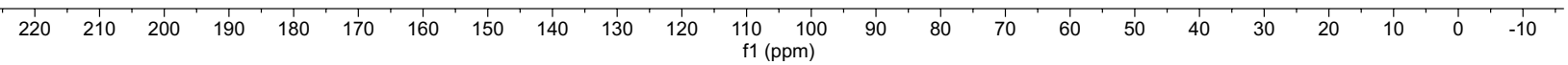


$1 \mathrm{H}$ NMR

$500 \mathrm{MHz}, \mathrm{CDCl}_{3}$
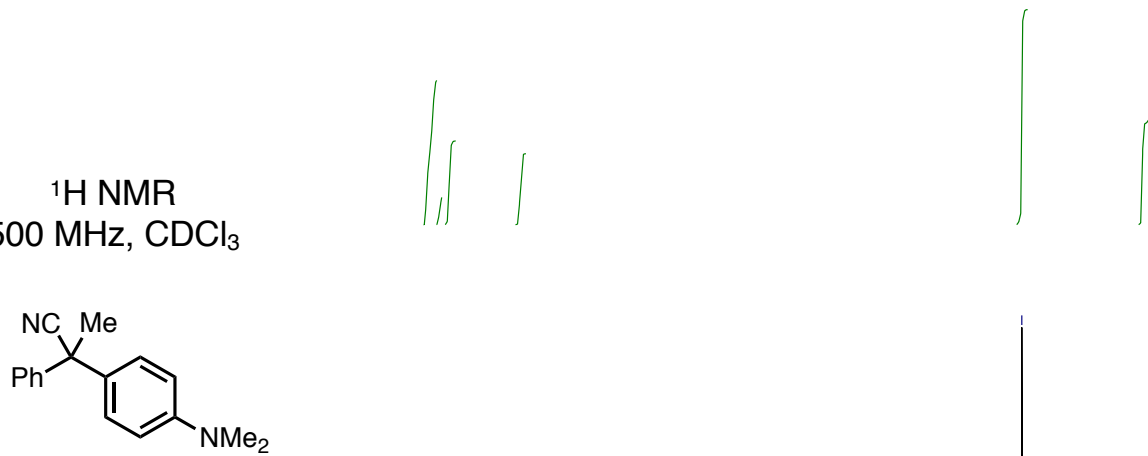

$2 f$

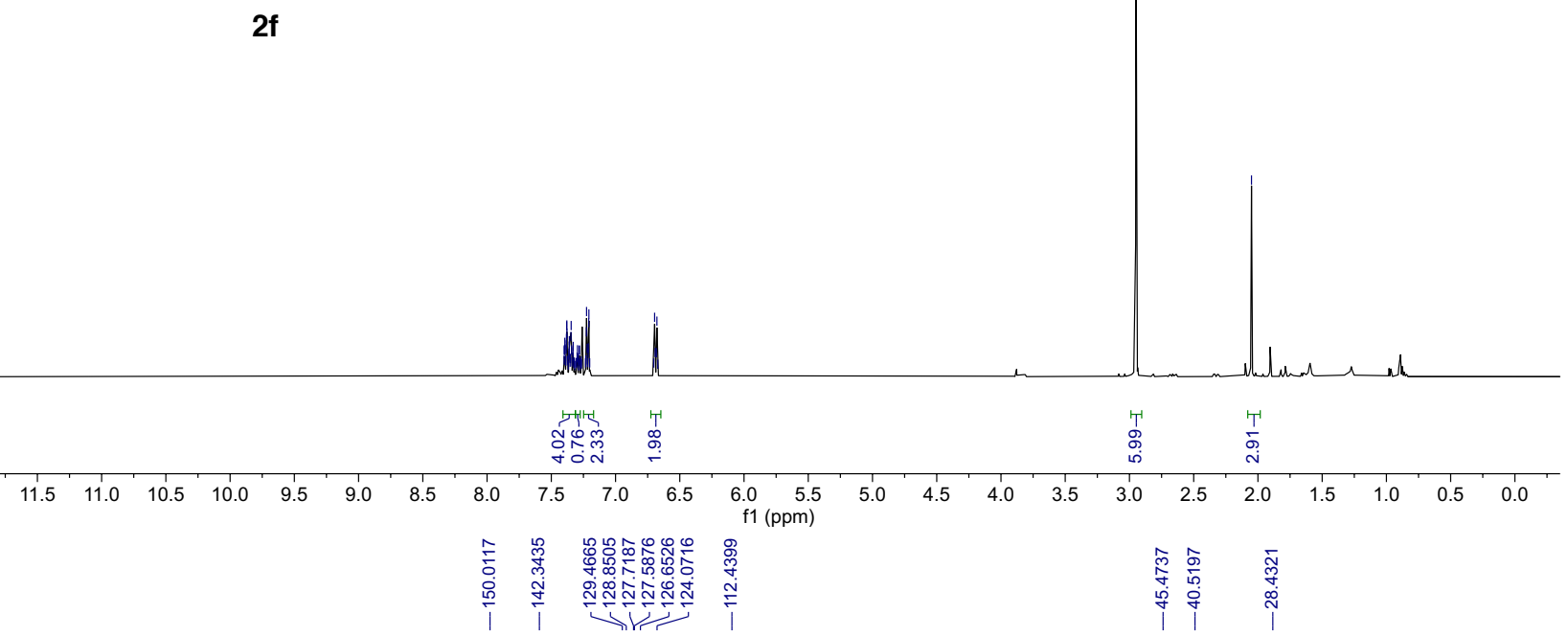

${ }^{13} \mathrm{C}\left\{{ }^{1} \mathrm{H}\right\} \mathrm{NMR}$

$125 \mathrm{MHz}, \mathrm{CDCl}_{3}$

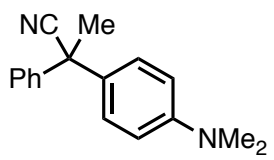

$2 f$ 


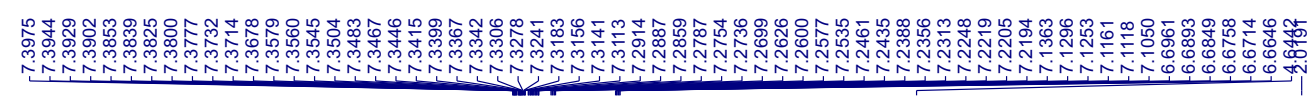

${ }^{1} \mathrm{H}$ NMR

$500 \mathrm{MHz}, \mathrm{CDCl}_{3}$<smiles>CN(Cc1ccccc1)c1ccc(C(C)(C)C)cc1</smiles>

$2 g$
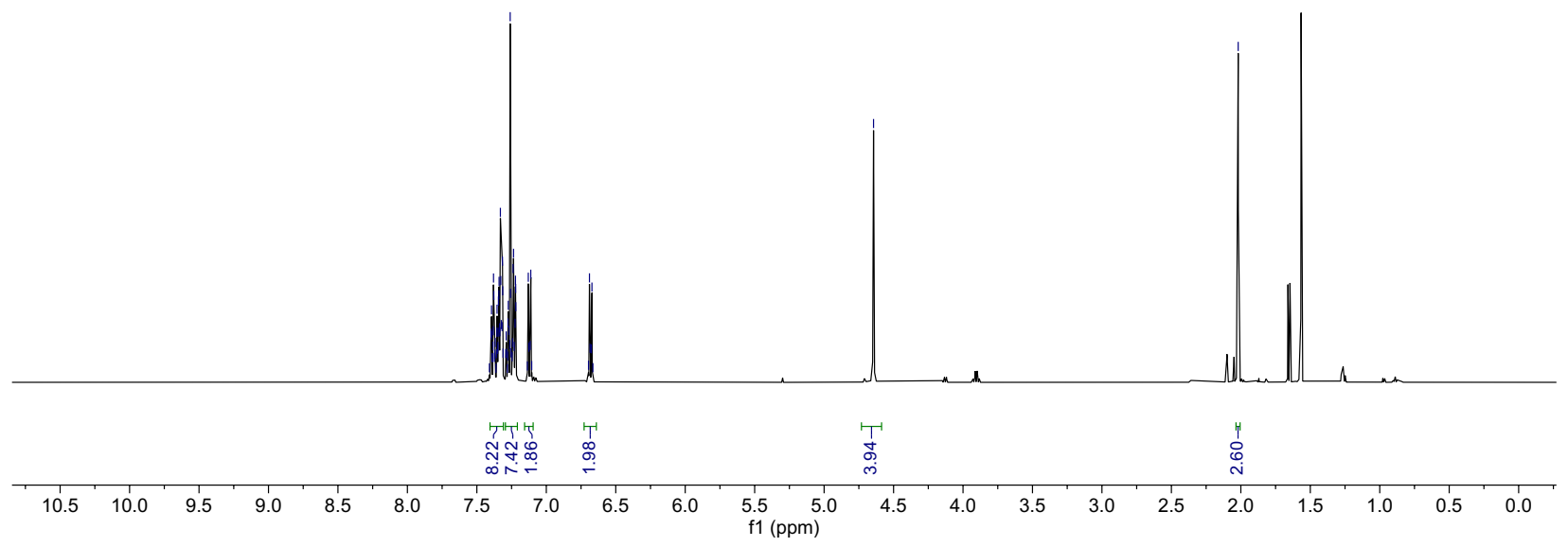

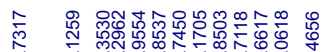

i

${ }^{13} \mathrm{C}\left\{{ }^{1} \mathrm{H}\right\}$ NMR

$125 \mathrm{MHz}, \mathrm{CDCl}_{3}$<smiles>CCCCc1ccc(C(C)(C)c2ccccc2)cc1</smiles>

$2 g$

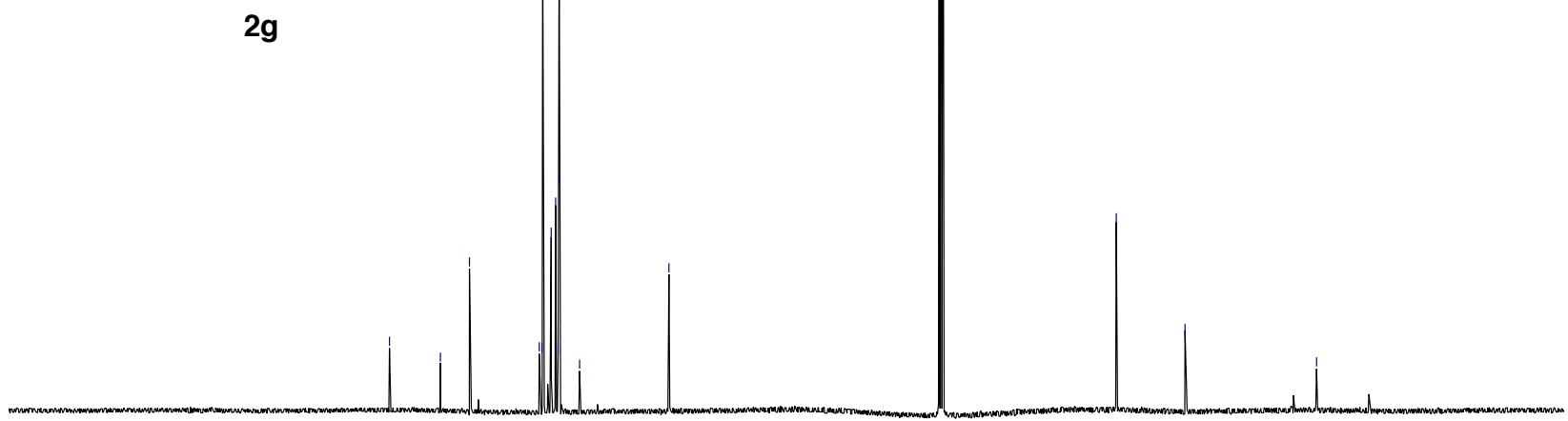

$\begin{array}{llllllllllllllllllll}190 & 180 & 170 & 160 & 150 & 140 & 130 & 120 & 110 & \begin{array}{l}100 \\ \mathrm{f} 1(\mathrm{ppm})\end{array} & 90 & 80 & 70 & 60 & 50 & 40 & 30 & 20 & 10 & 0\end{array}$




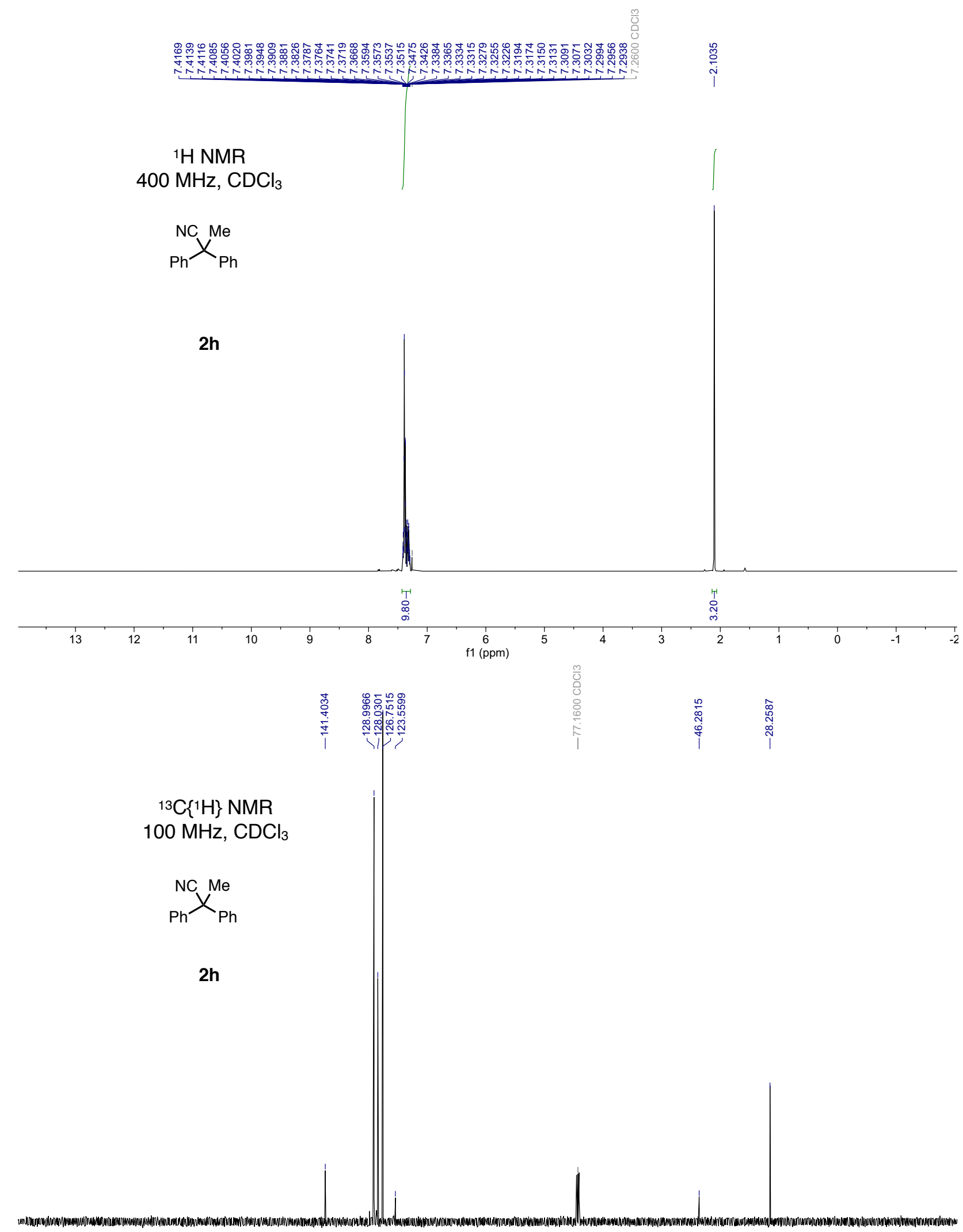

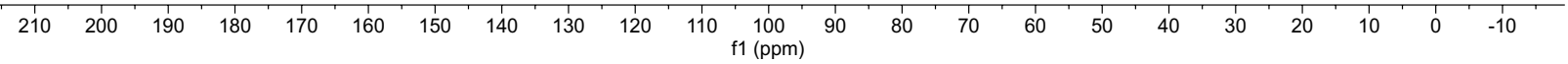




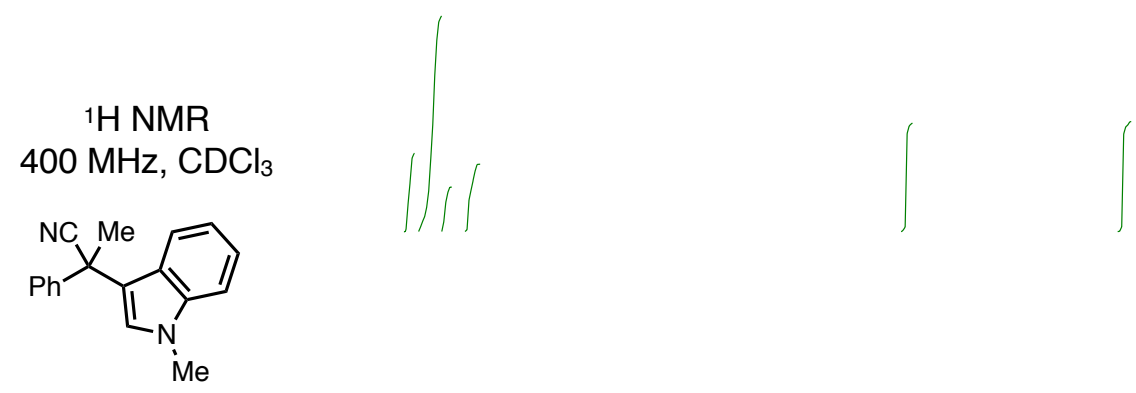

2i

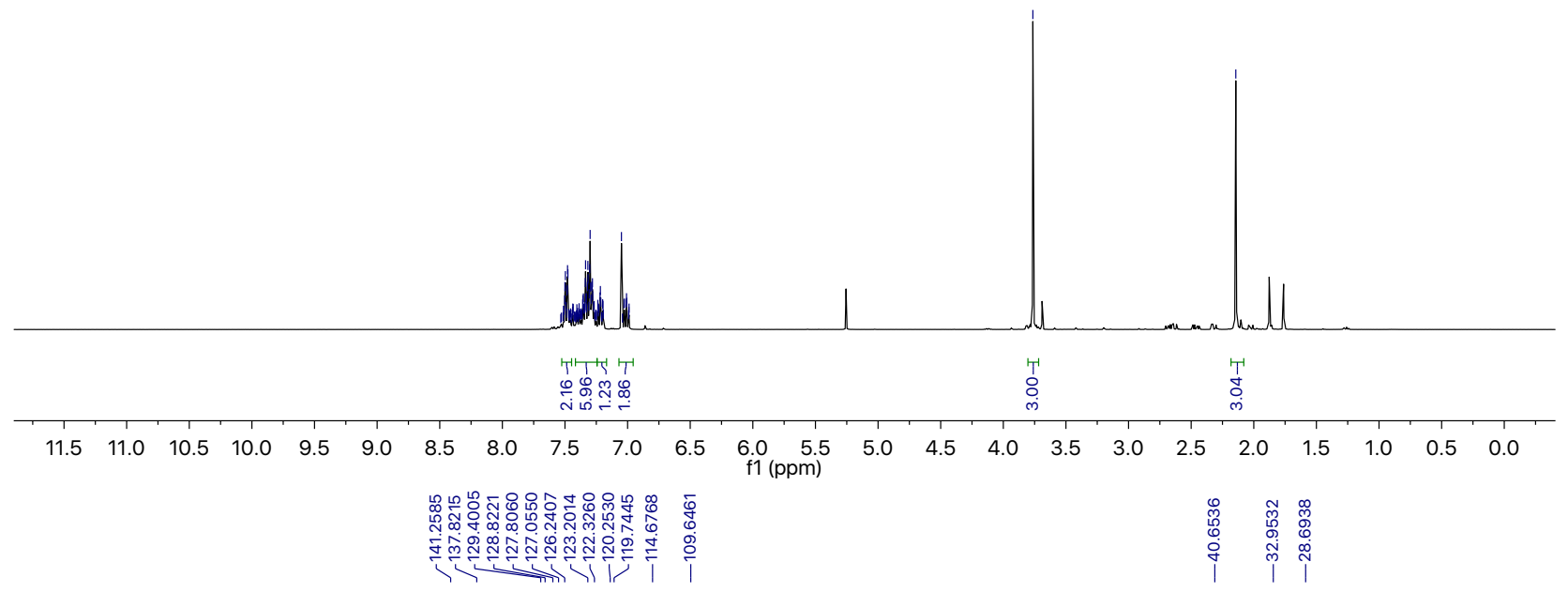

${ }^{13} \mathrm{C}\left\{{ }^{1} \mathrm{H}\right\}$ NMR

$100 \mathrm{MHz}, \mathrm{CDCl}_{3}$<smiles>Cn1cc(C(C)(C#N)c2ccccc2)c2ccccc21</smiles>

2i

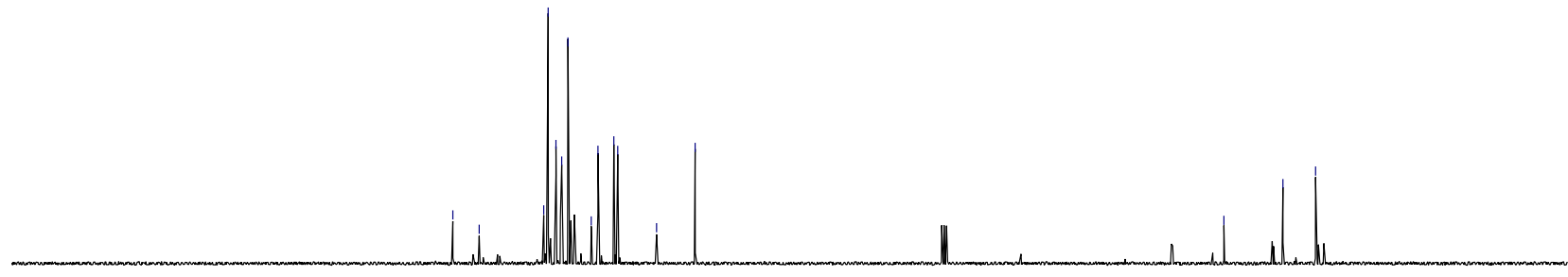

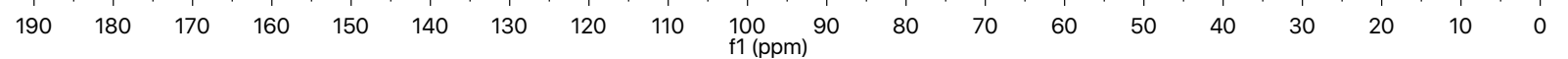



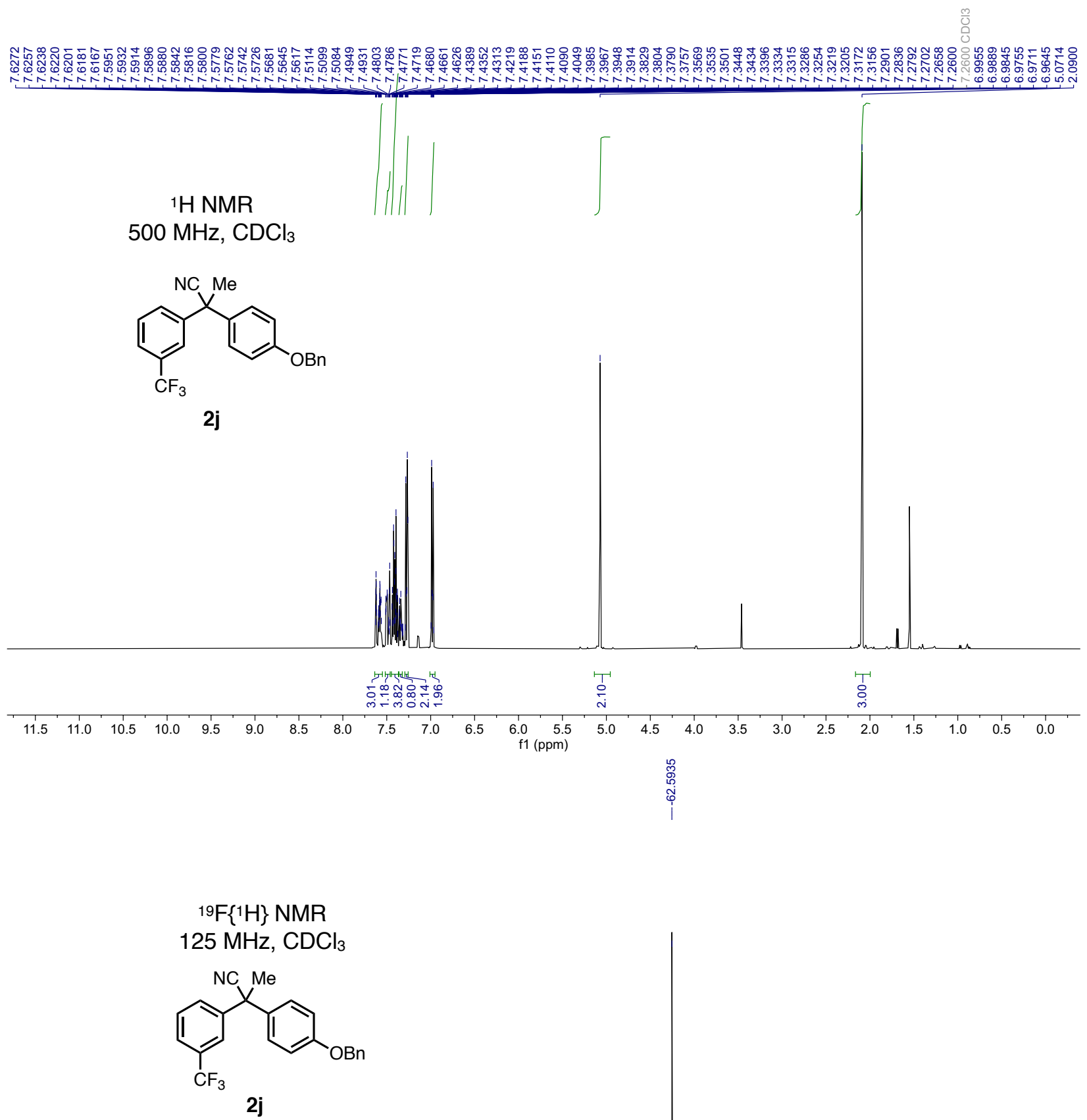

$\begin{array}{llllllllllllllllllllll}170 & 150 & 130 & 110 & 90 & 70 & 50 & 30 & 10 & -10 & -30 & -50 & -70 & -90 & -110 & -130 & -150 & -170 & -190 & -210\end{array}$




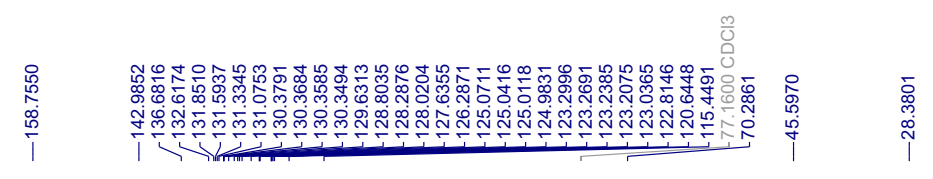

${ }^{13} \mathrm{C}\left\{{ }^{1} \mathrm{H}\right\} \mathrm{NMR}$
$125 \mathrm{MHz}, \mathrm{CDCl}_{3}$<smiles>CC(C)(c1ccc(C(F)(F)F)cc1)c1cccc(OCCc2ccccc2)c1</smiles>

2j

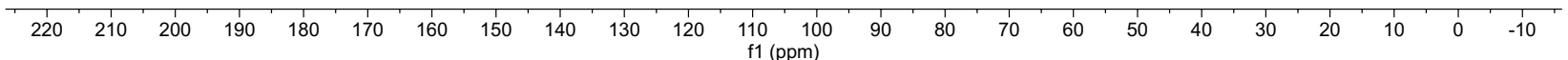




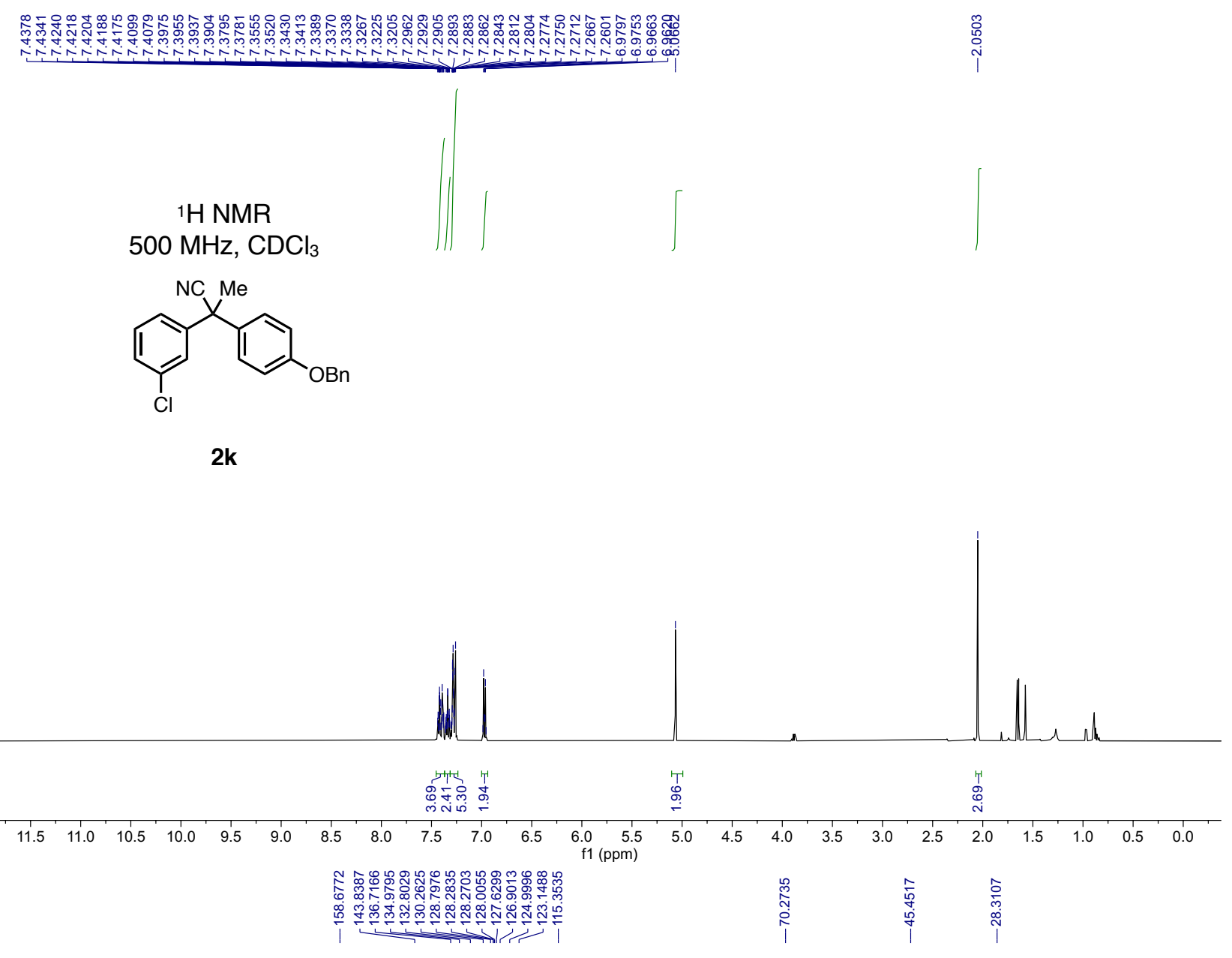

${ }^{13} \mathrm{C}\left\{{ }^{1} \mathrm{H}\right\} \mathrm{NMR}$

$125 \mathrm{MHz} \mathrm{CDCl}_{3}$<smiles>CC(C)(c1ccc(OCc2ccccc2)cc1)c1cccc(Cl)c1</smiles>

2k

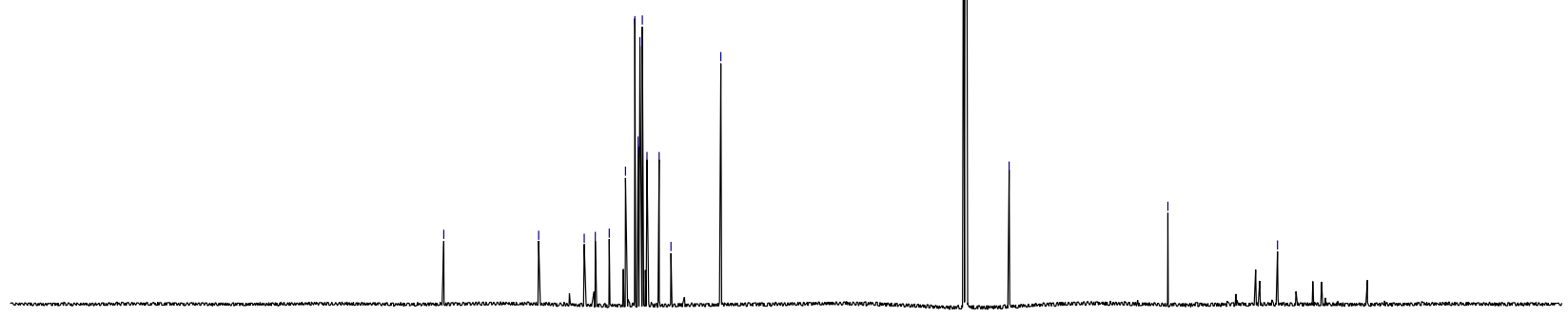

\begin{tabular}{|l|llllllllllllllllllllllll}
120 & 210 & 200 & 190 & 180 & 170 & 160 & 150 & 140 & 130 & 120 & $\begin{array}{c}110 \\
\mathrm{f} 1(\mathrm{ppm})\end{array}$ & 90 & 80 & 70 & 60 & 50 & 40 & 30 & 20 & 10 & 0 & -10
\end{tabular} 
${ }^{1} \mathrm{H}$ NMR

$500 \mathrm{MHz}, \mathrm{CDCl}_{3}$<smiles>Cc1ccc(C(C)(C)c2cccc(Cl)c2)cc1</smiles>

2)

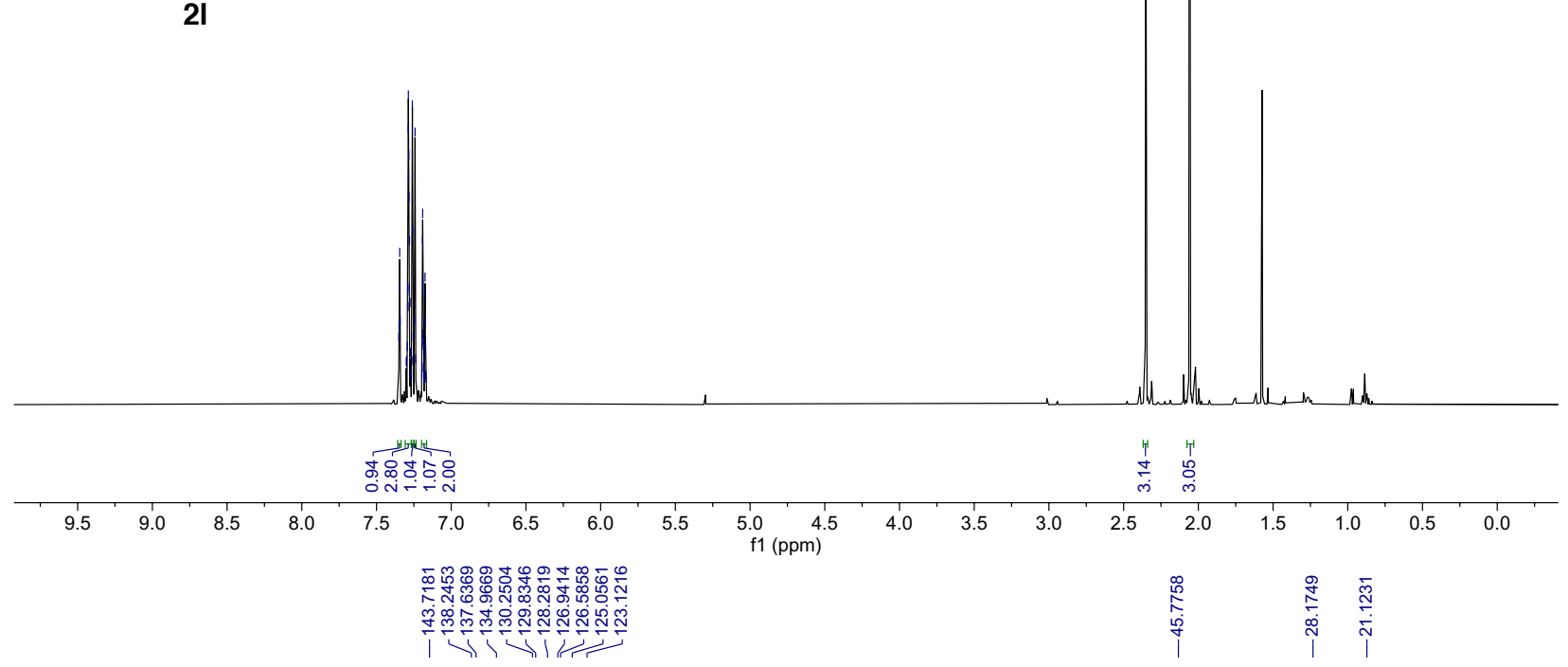

${ }^{13} \mathrm{C}\left\{{ }^{1} \mathrm{H}\right\} \mathrm{NMR}$

$125 \mathrm{MHz}^{\mathrm{CDCl}_{3}}$<smiles>Cc1ccc(C(C)(C)c2cccc(Cl)c2)cc1</smiles>

2)

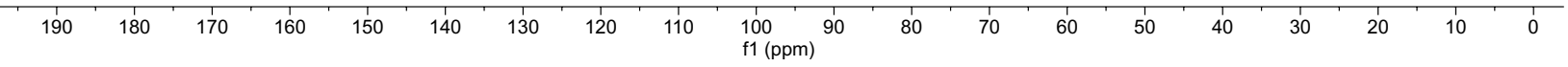




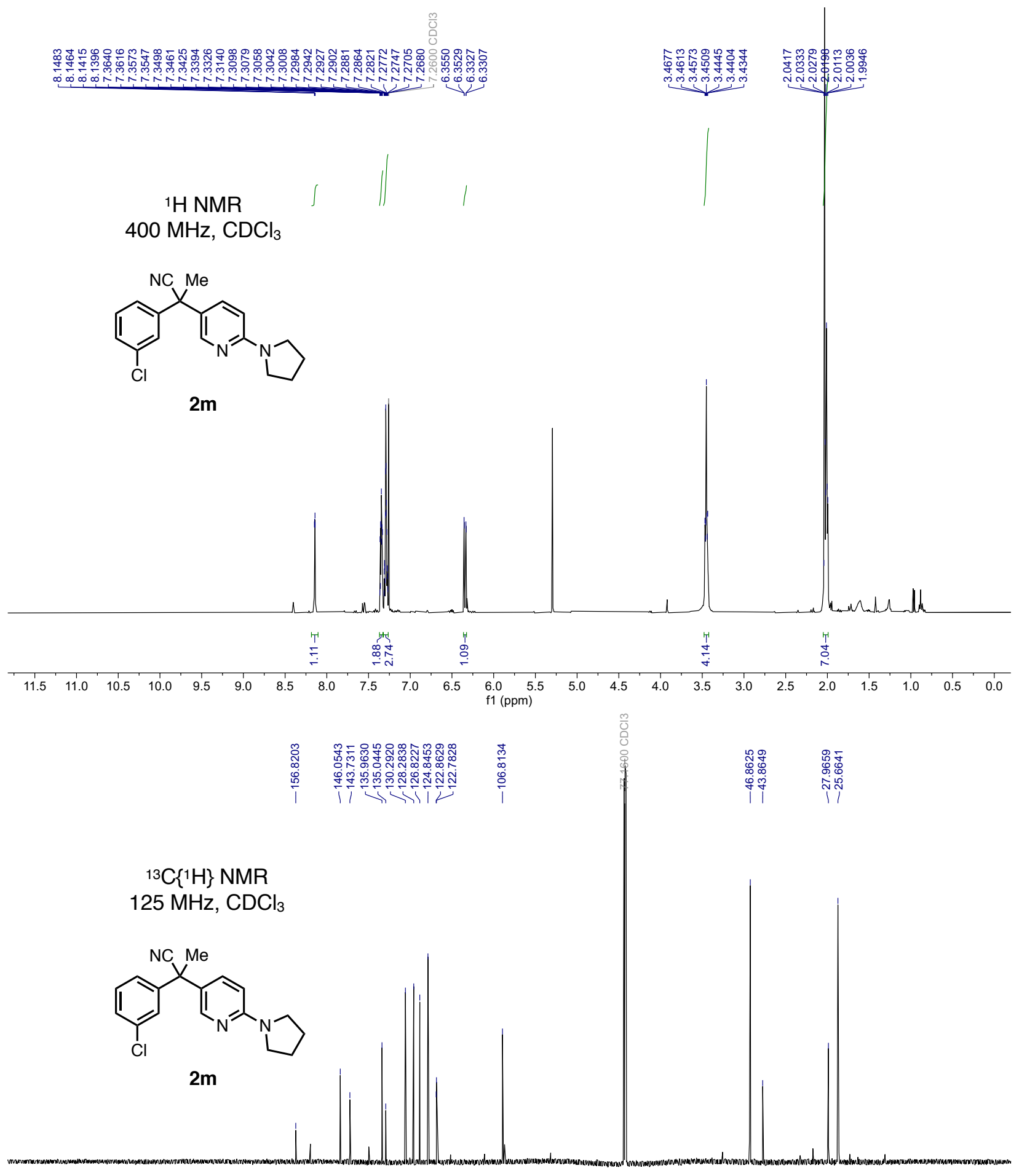

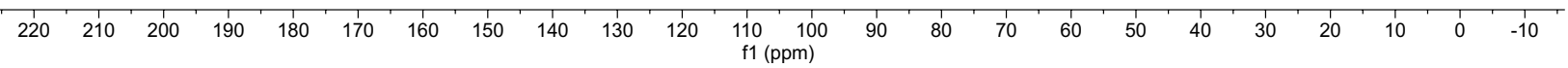




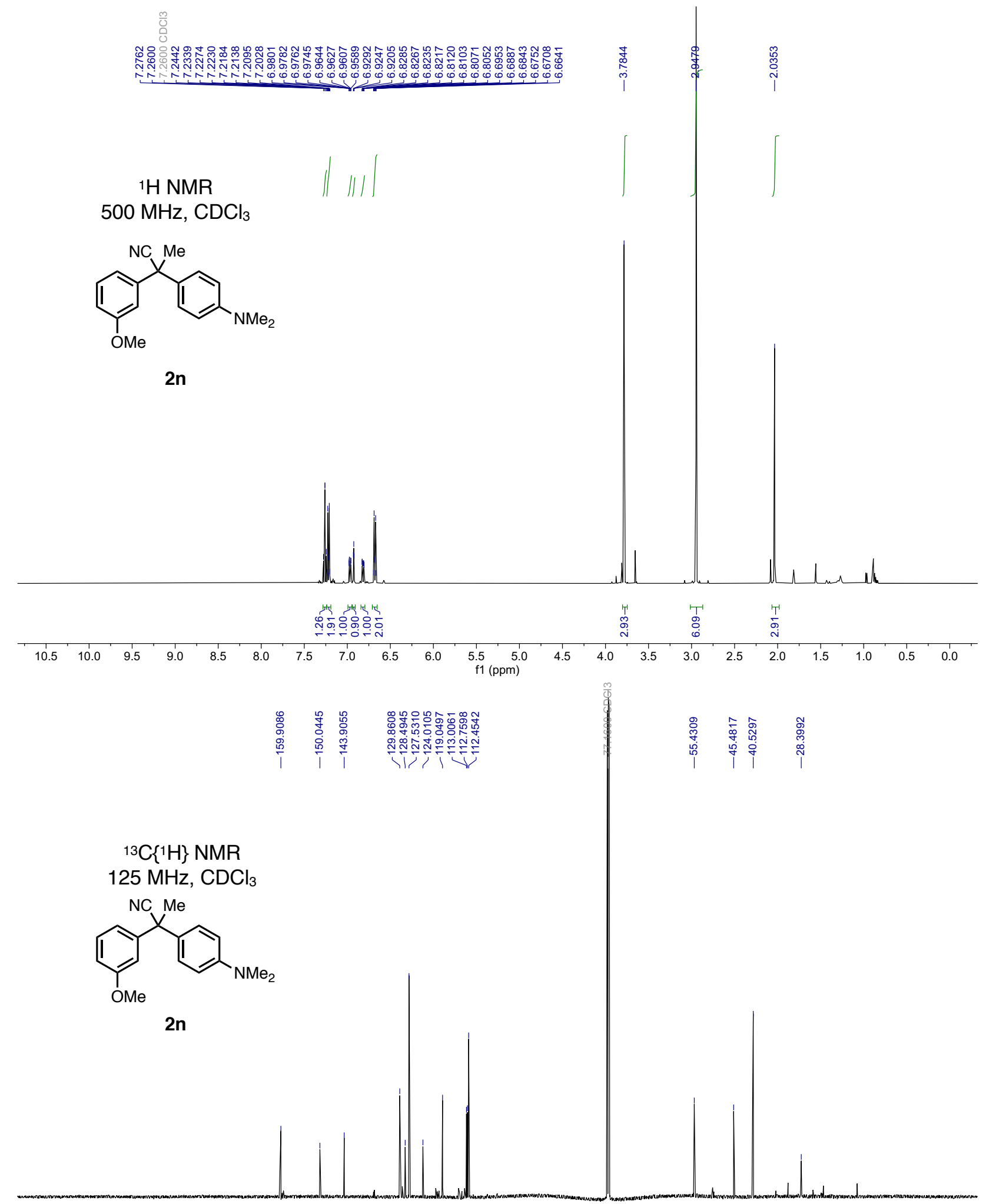

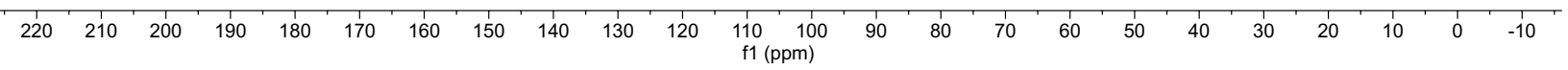




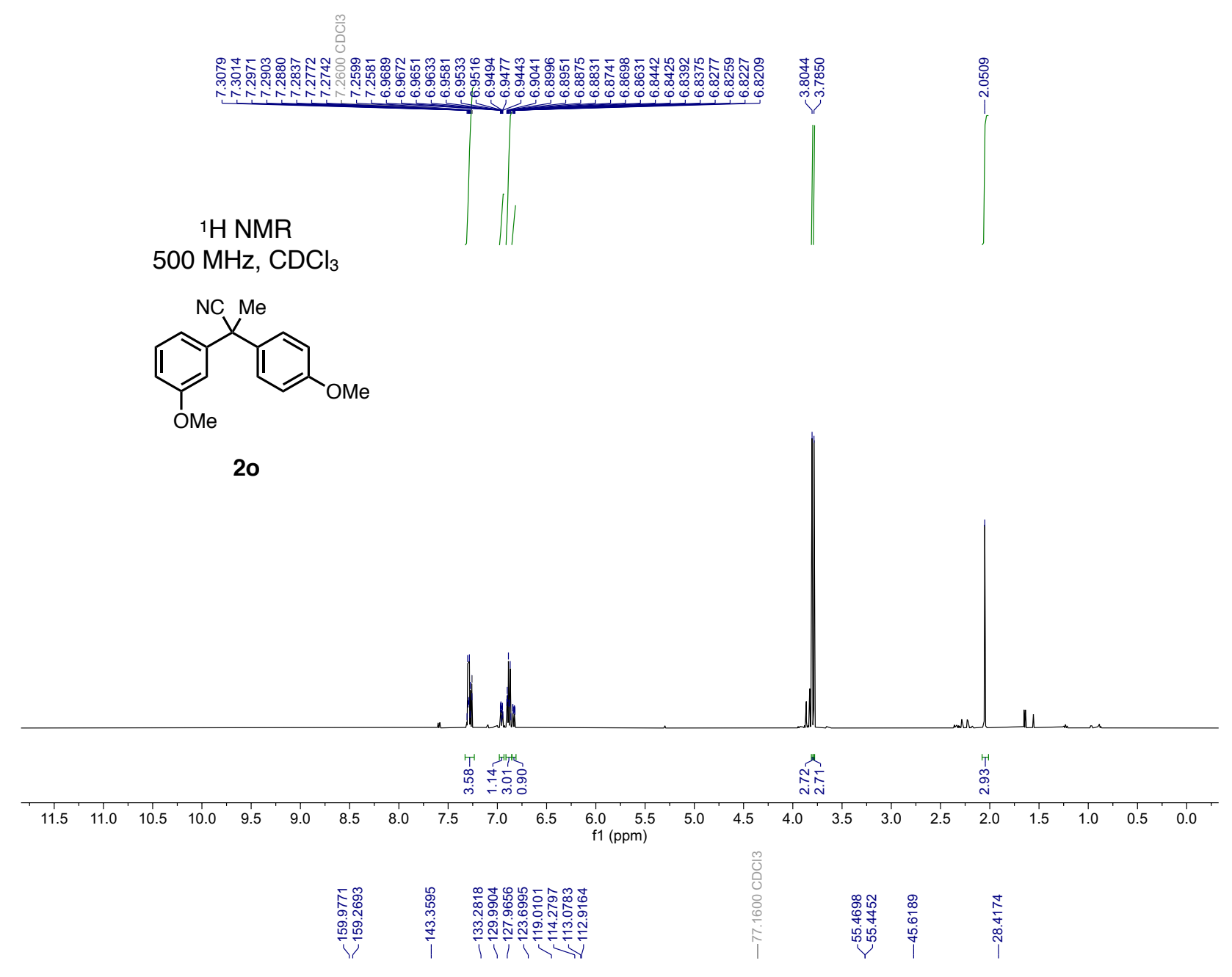

${ }^{13} \mathrm{C}\left\{{ }^{1} \mathrm{H}\right\}$ NMR

$125 \mathrm{MHz}, \mathrm{CDCl}_{3}$

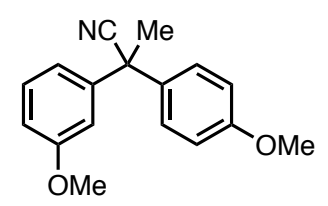

20

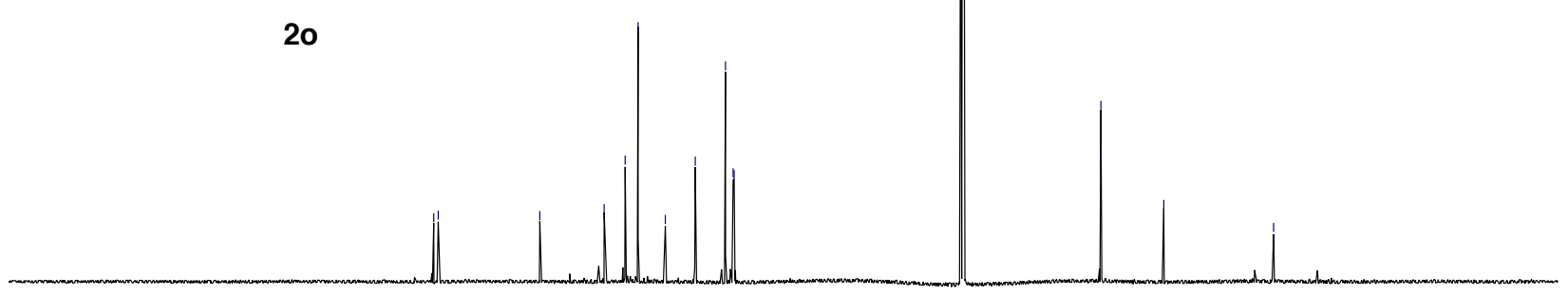

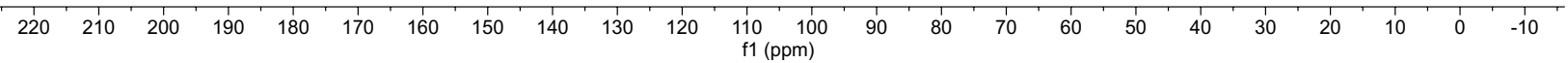




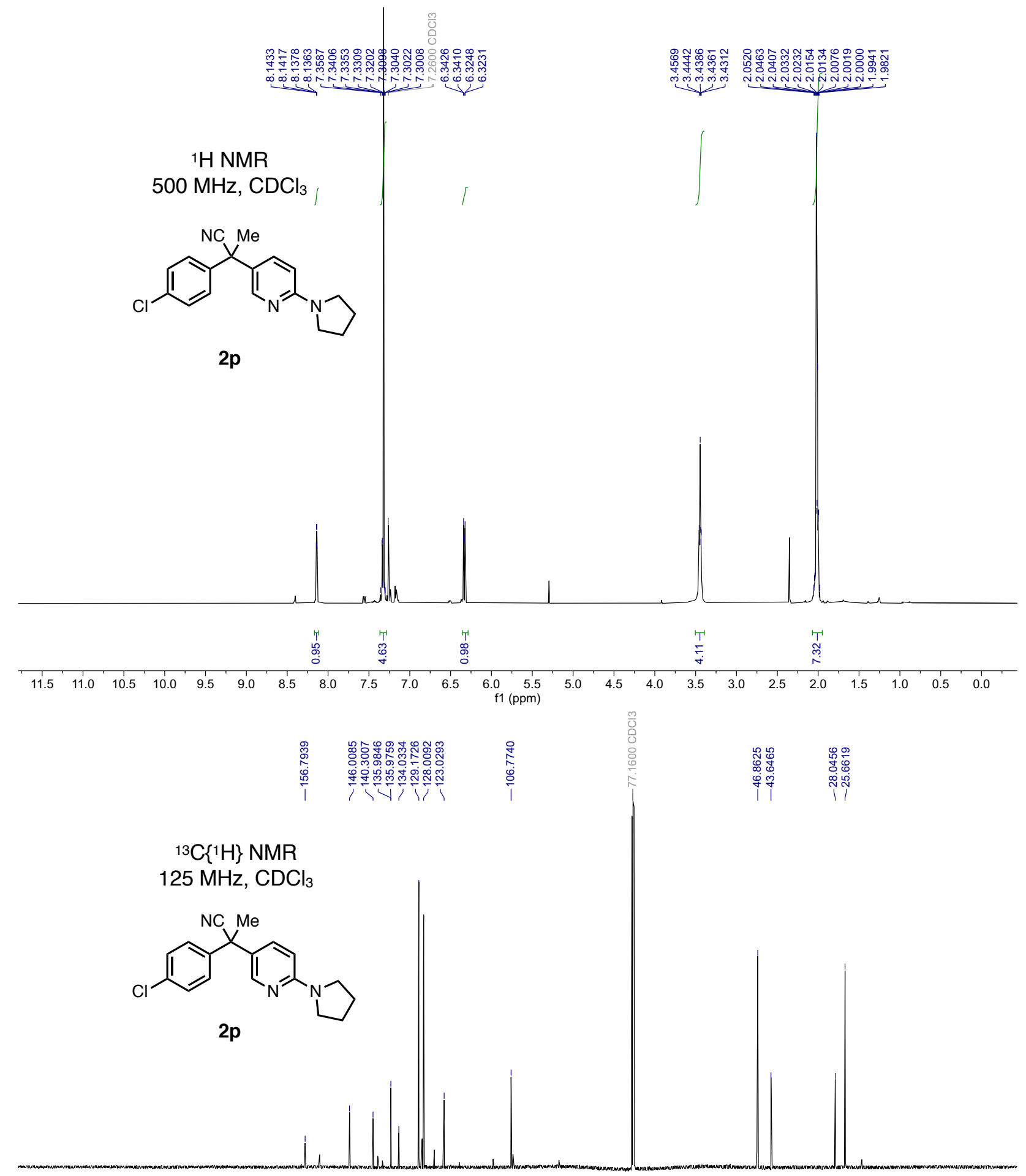

$\begin{array}{llllllllllllllllllllllll}1 & 120 & 210 & 200 & 190 & 180 & 170 & 160 & 150 & 140 & 130 & 120 & \begin{array}{c}110 \\ \mathrm{f} 1(\mathrm{ppm})\end{array} & 90 & 80 & 70 & 60 & 50 & 40 & 30 & 20 & 10 & 0 & -10\end{array}$ 

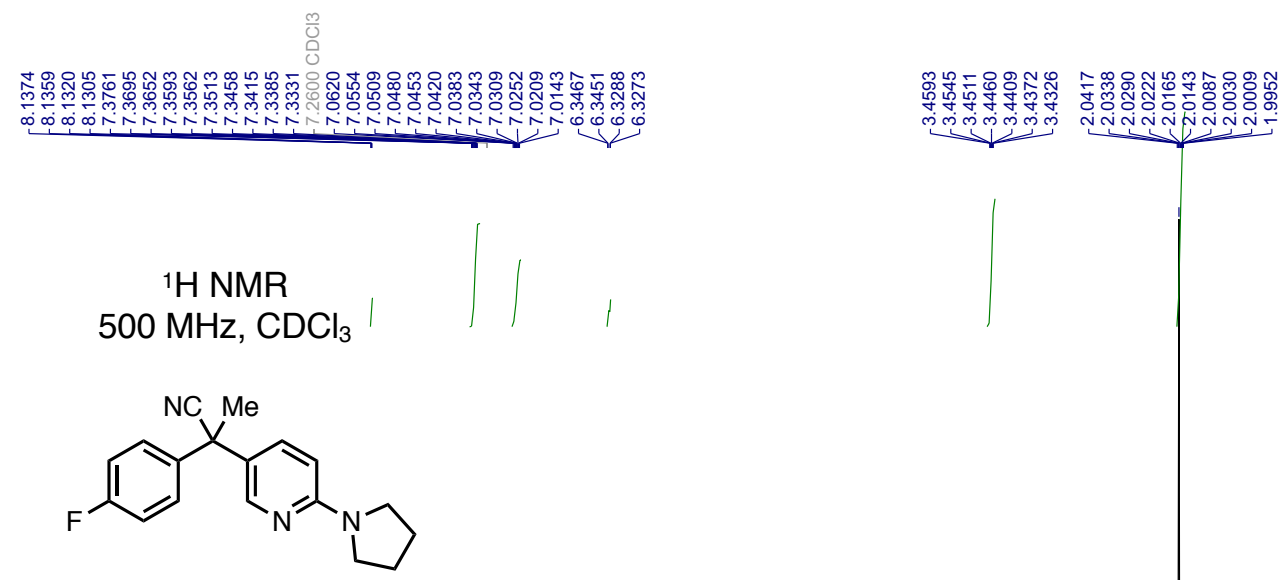

$2 q$

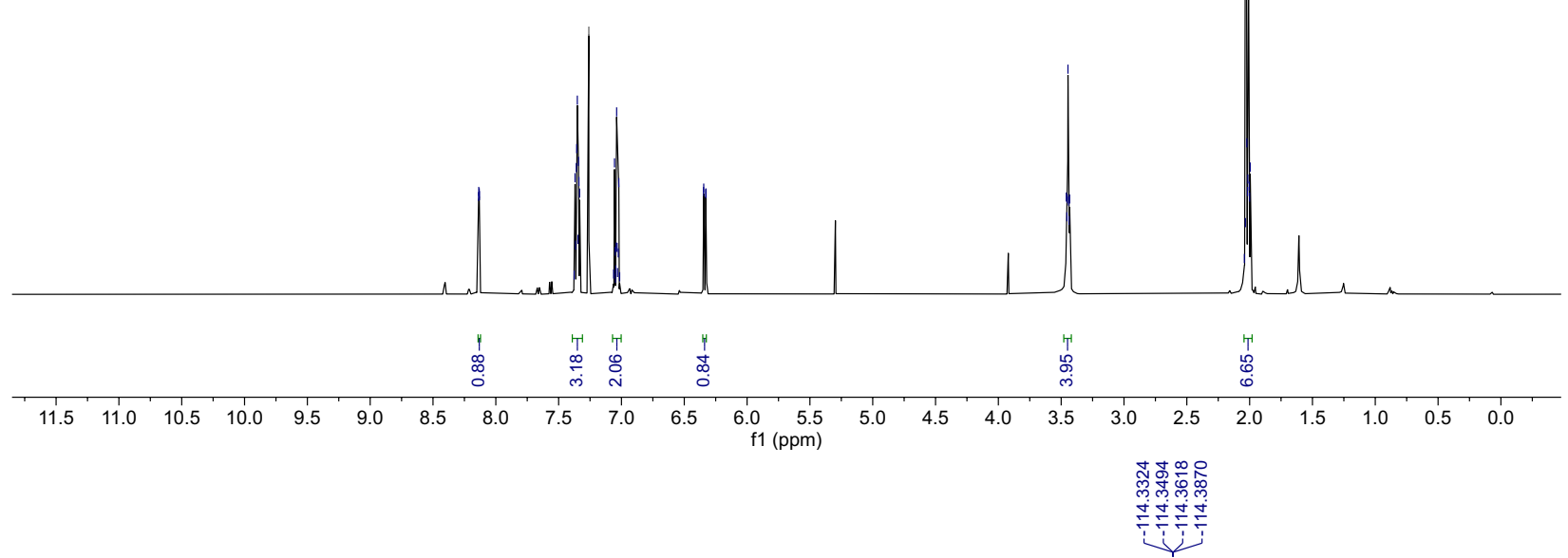

${ }^{19} \mathrm{~F}\left\{{ }^{1} \mathrm{H}\right\}$ NMR

$376 \mathrm{MHz}, \mathrm{CDCl}_{3}$<smiles>CC(C)(c1ccc(F)cc1)c1ccc(N2CCCC2)nc1</smiles>

$2 q$

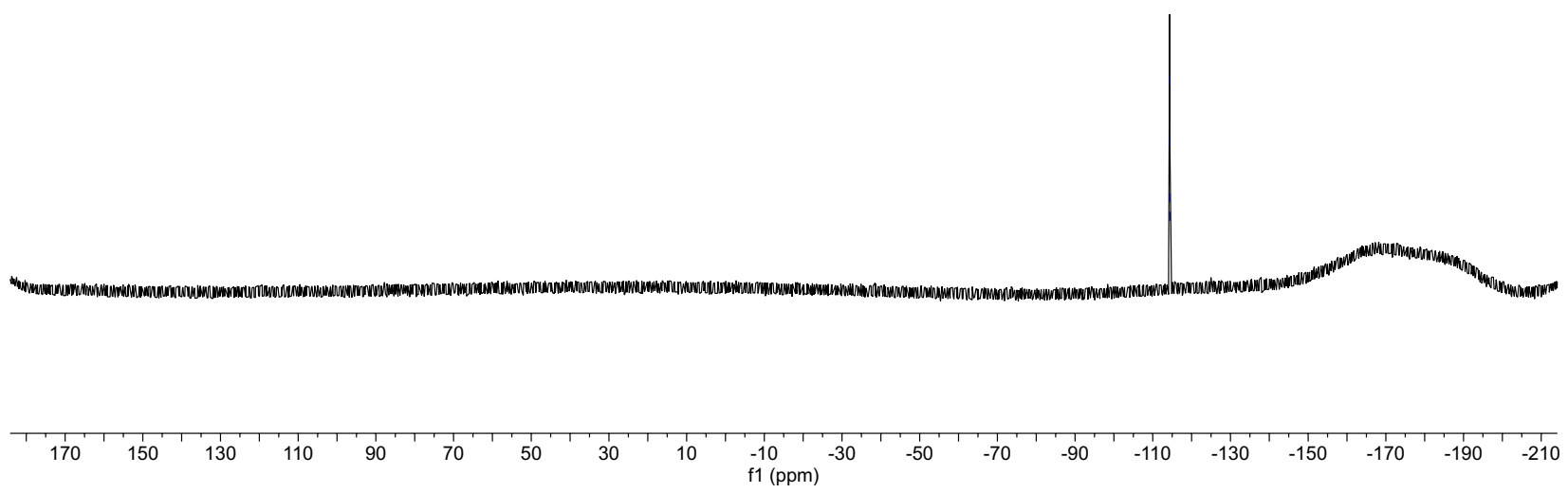




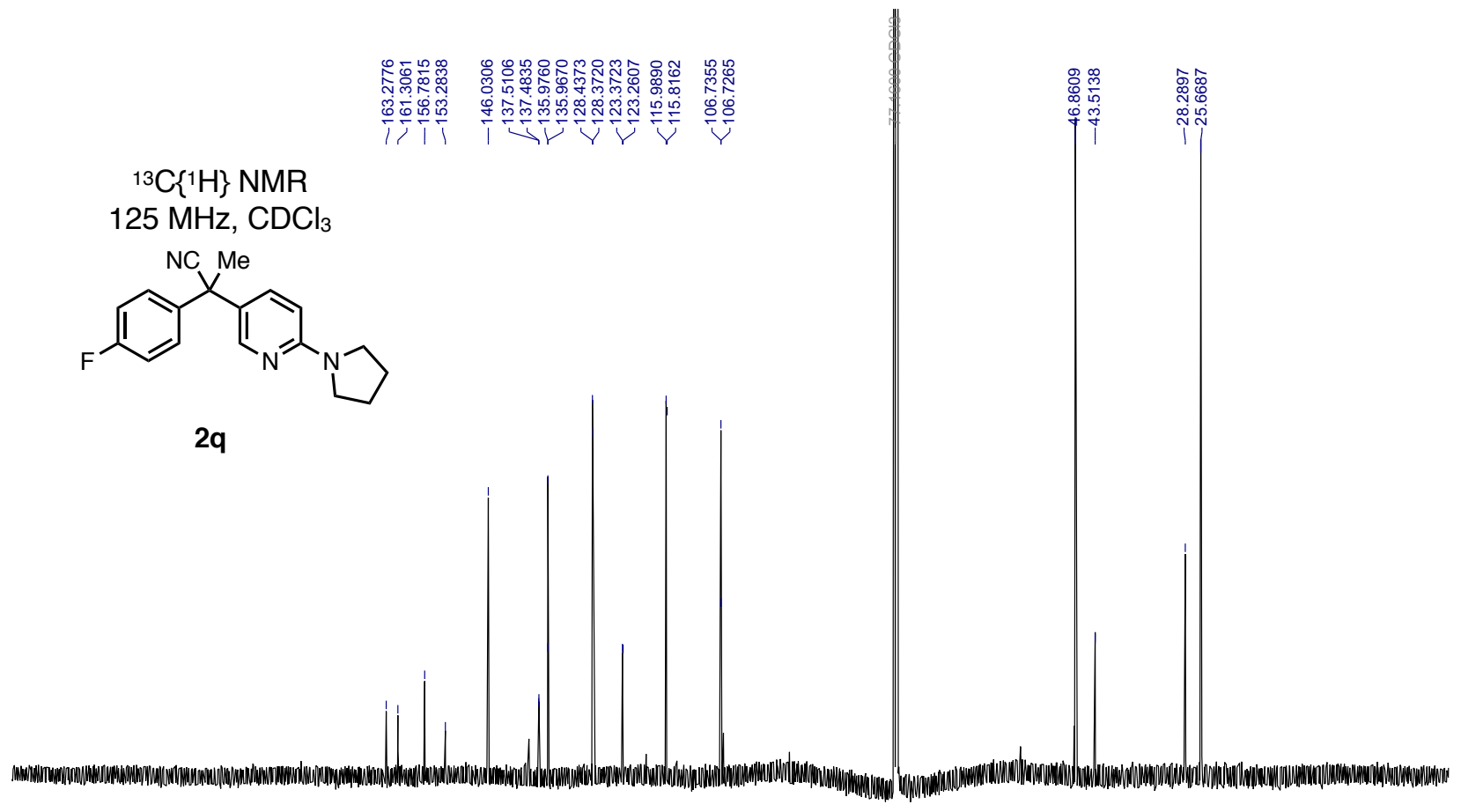

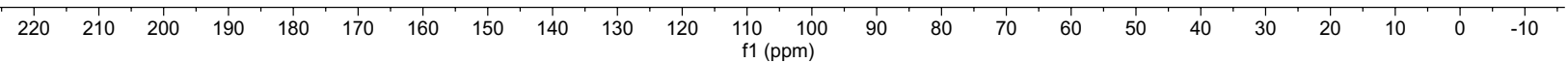




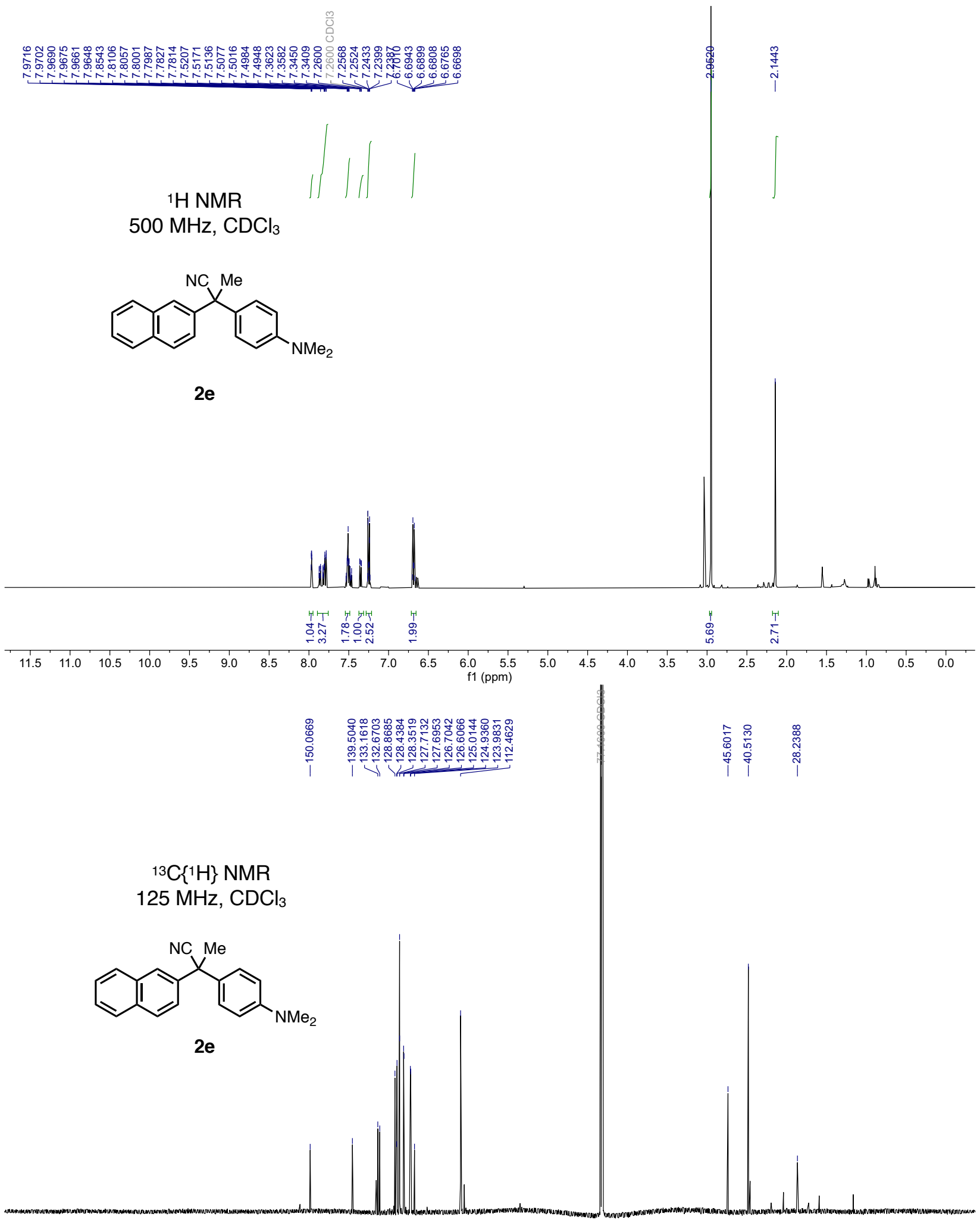

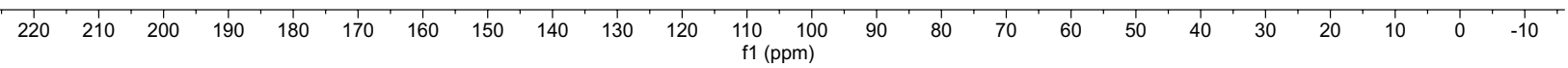




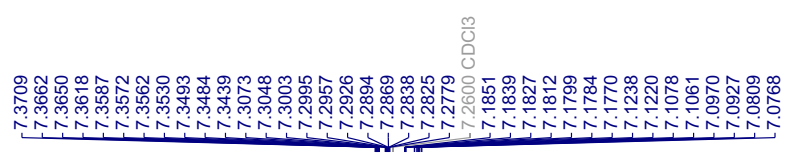

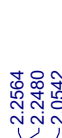

$1 \mathrm{H} \mathrm{NMR}$
$500 \mathrm{MHz}, \mathrm{CDCl}_{3} \quad \| / /$<smiles>Cc1ccc(C(C)(C)c2ccc(C(C)(C)C)cc2)cc1C</smiles>

2s

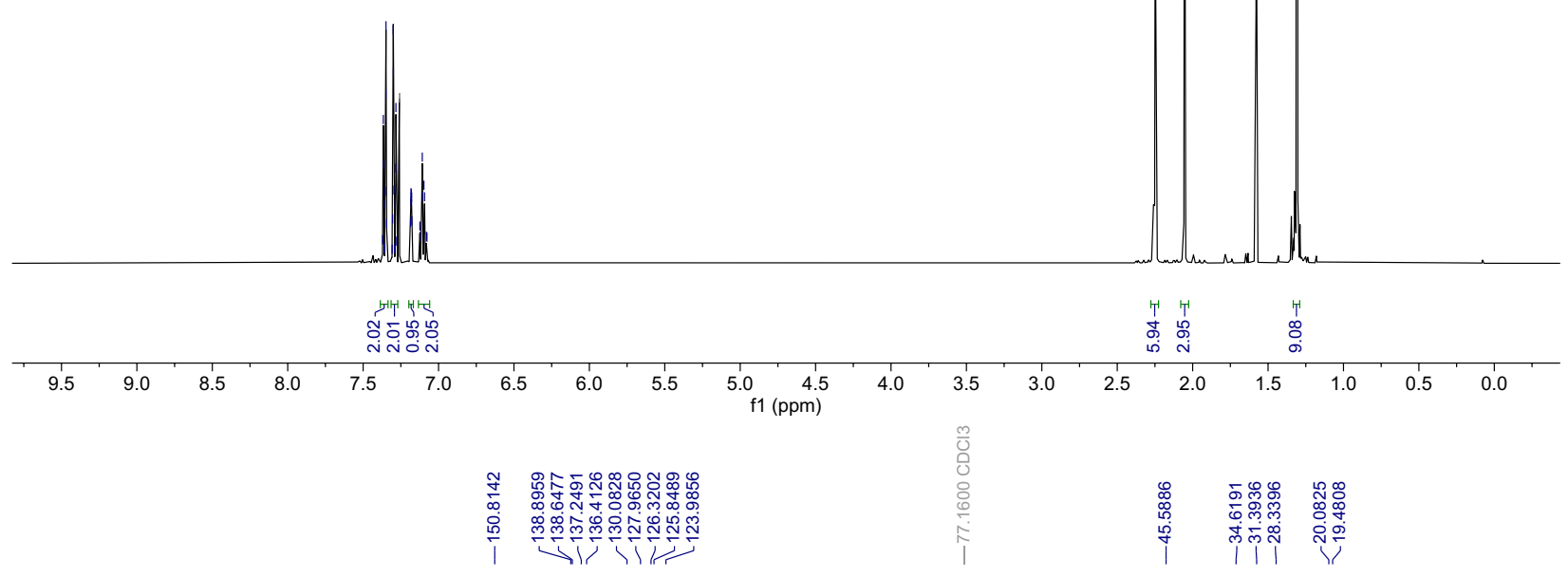

${ }^{13} \mathrm{C}\left\{{ }^{1} \mathrm{H}\right\}$ NMR

$125 \mathrm{MHz}, \mathrm{CDCl}_{3}$

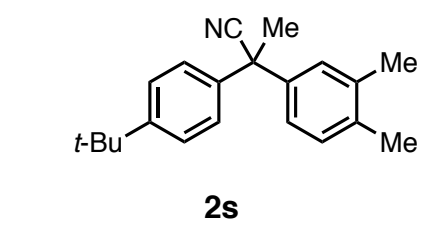

2s

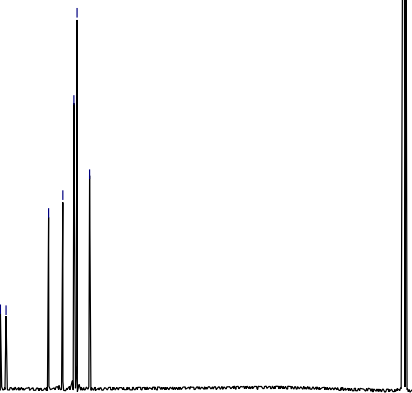

\begin{tabular}{lllllllllllllllllllllllll}
\hline & 220 & 210 & 200 & 190 & 180 & 170 & 160 & 150 & 140 & 130 & 120 & $\begin{array}{c}110 \\
\mathrm{f} 1(\mathrm{ppm})\end{array}$ & 90 & 80 & 70 & 60 & 50 & 40 & 30 & 20 & 10 & 0 & -10
\end{tabular} 

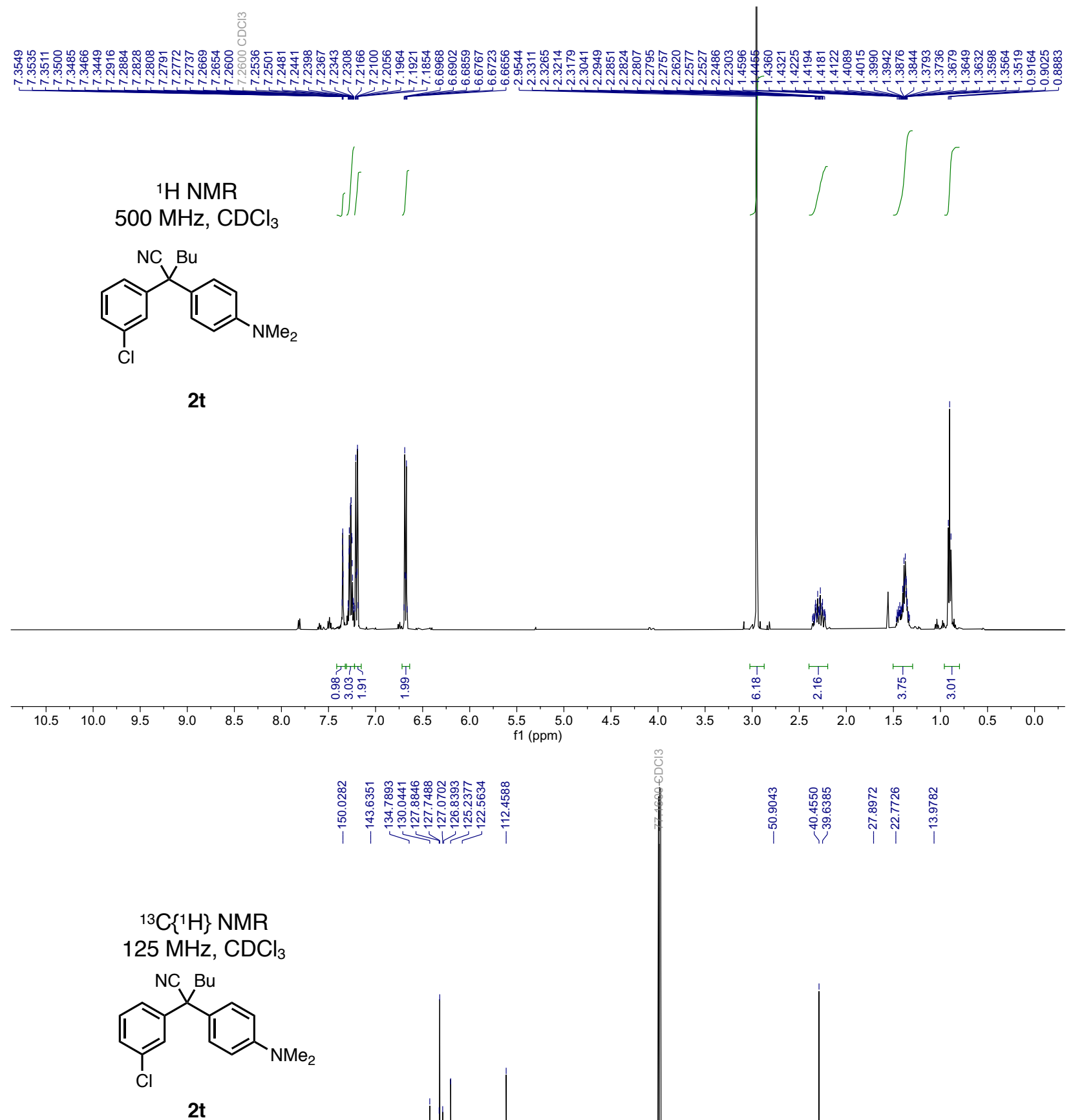

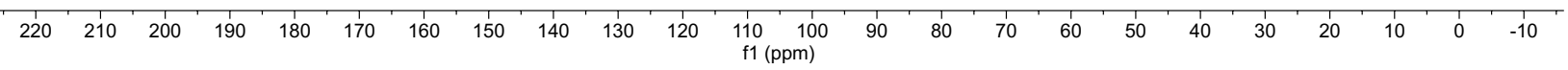




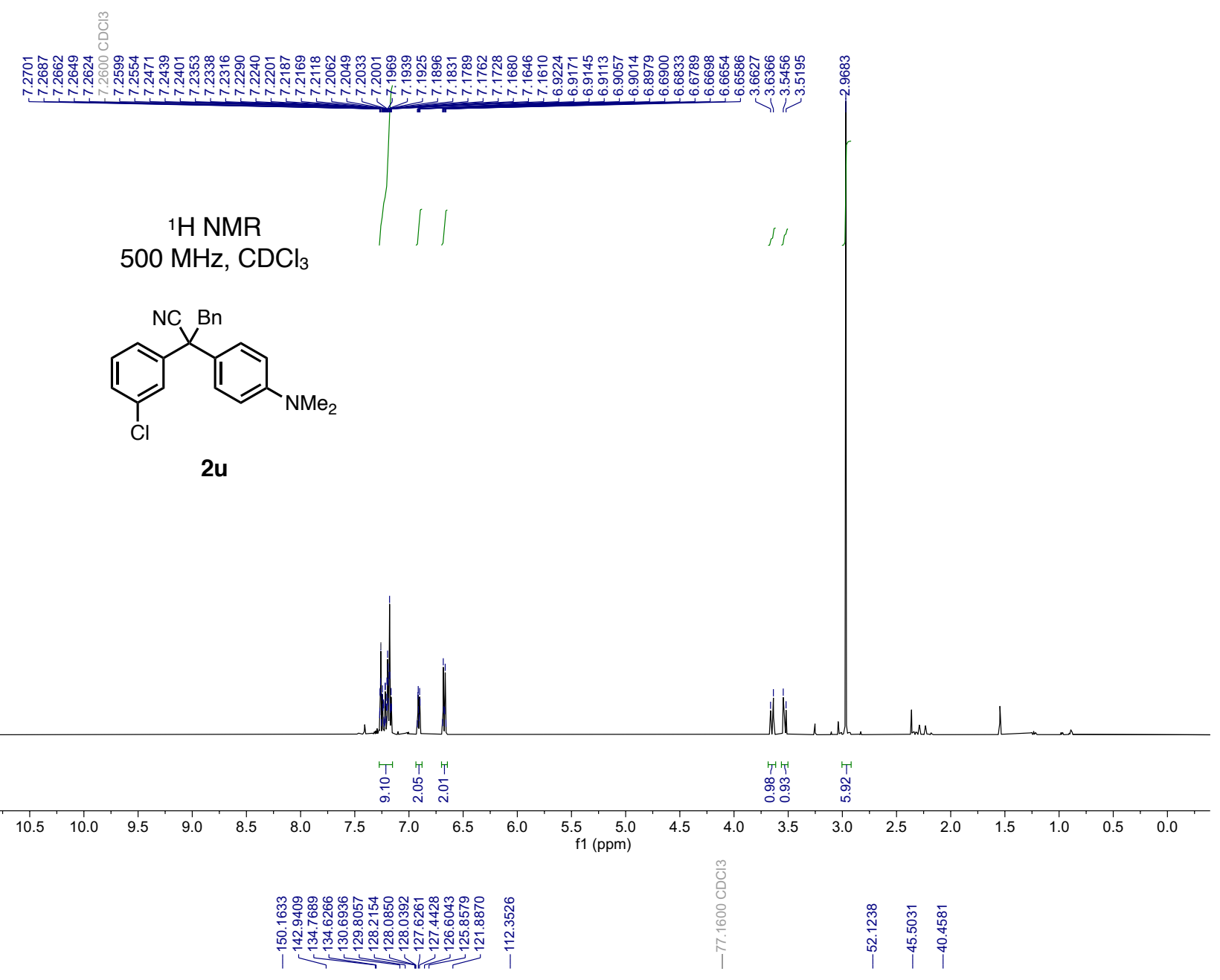

${ }^{13} \mathrm{C}\left\{{ }^{1} \mathrm{H}\right\} \mathrm{NMR}$

$125 \mathrm{MHz}, \mathrm{CDCl}_{3}$<smiles>CNc1ccc(C(Br)(C#N)c2cccc(Cl)c2)cc1</smiles>

$2 u$

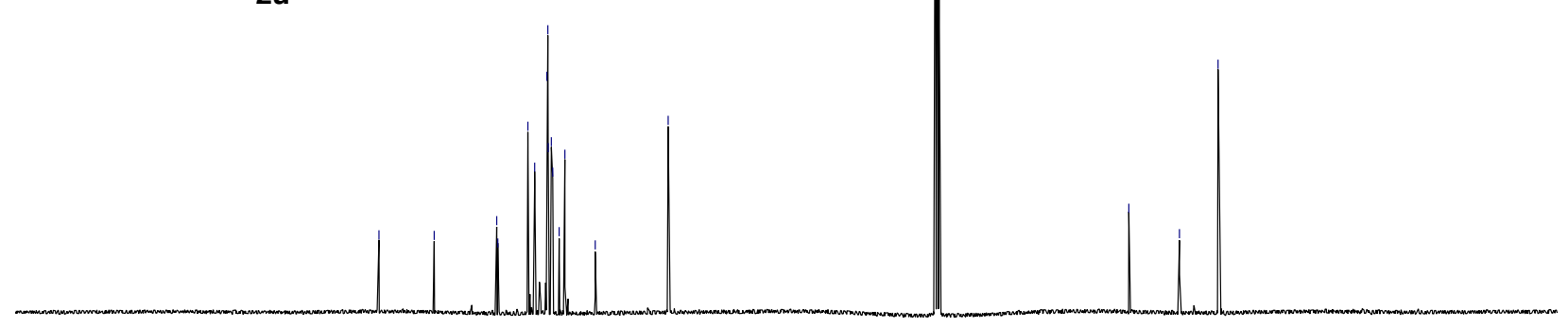

$\begin{array}{llllllllllllllllllll}190 & 180 & 170 & 160 & 150 & 140 & 130 & 120 & 110 & \begin{array}{l}100 \\ \mathrm{f} 1(\mathrm{ppm})\end{array} & 90 & 80 & 70 & 60 & 50 & 40 & 30 & 20 & 10 & 0\end{array}$




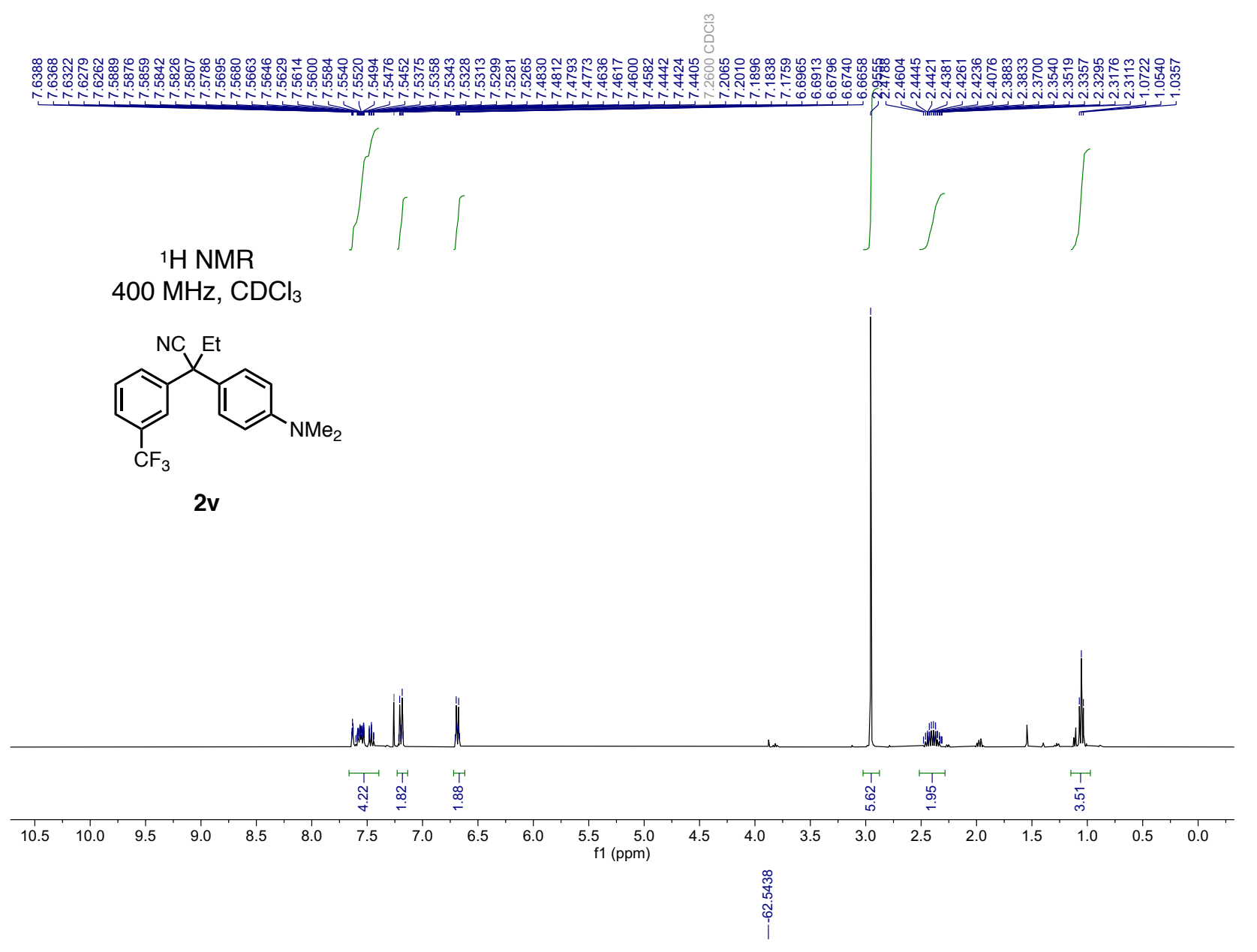

${ }^{19} \mathrm{~F}\left\{{ }^{1} \mathrm{H}\right\}$ NMR

$376 \mathrm{MHz}, \mathrm{CDCl}_{3}$

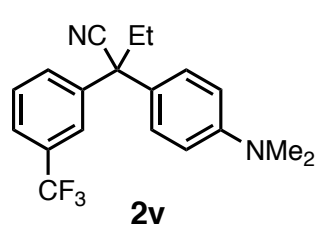

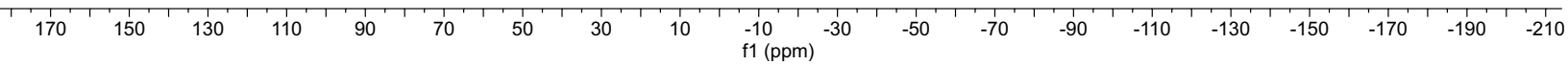




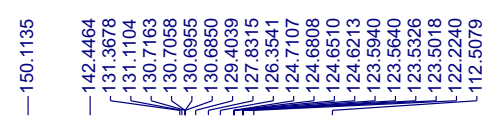

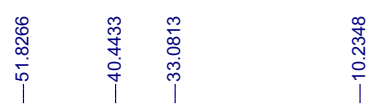

${ }^{13} \mathrm{C}\{1 \mathrm{H}\} \mathrm{NMR}$

$125 \mathrm{MHz} \mathrm{CDCl}_{3}$
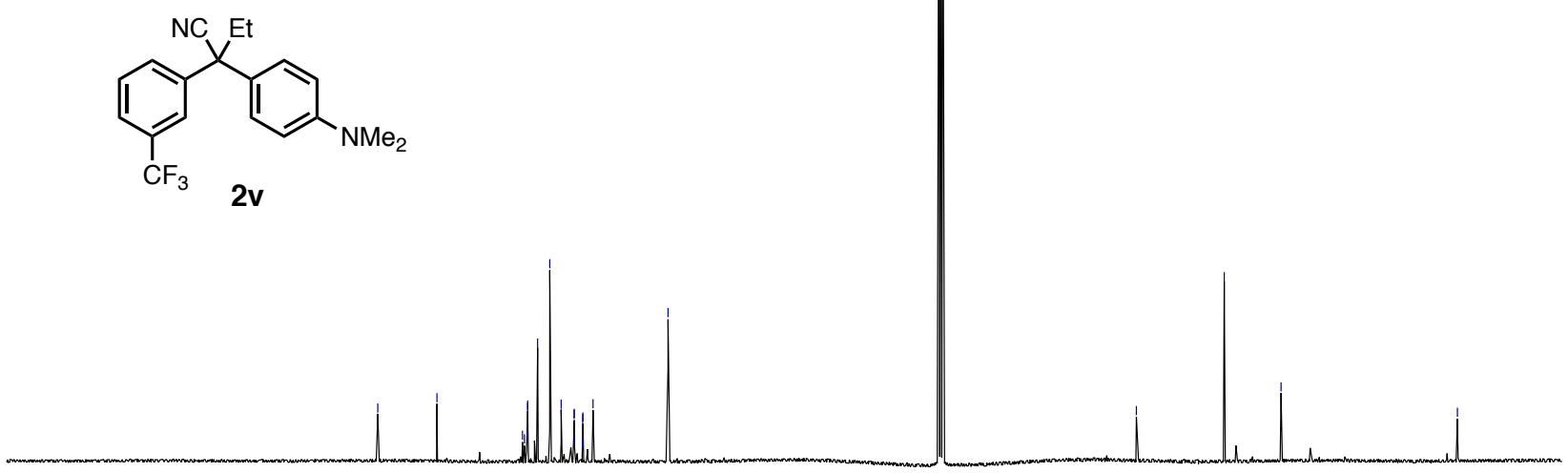

$\begin{array}{lllllllllllllllllllll}\mid & 190 & 180 & 170 & 160 & 150 & 140 & 130 & 120 & 110 & \begin{array}{l}100 \\ \mathrm{f} 1(\mathrm{ppm})\end{array} & 90 & 80 & 70 & 60 & 50 & 40 & 30 & 20 & 10 & 0\end{array}$ 


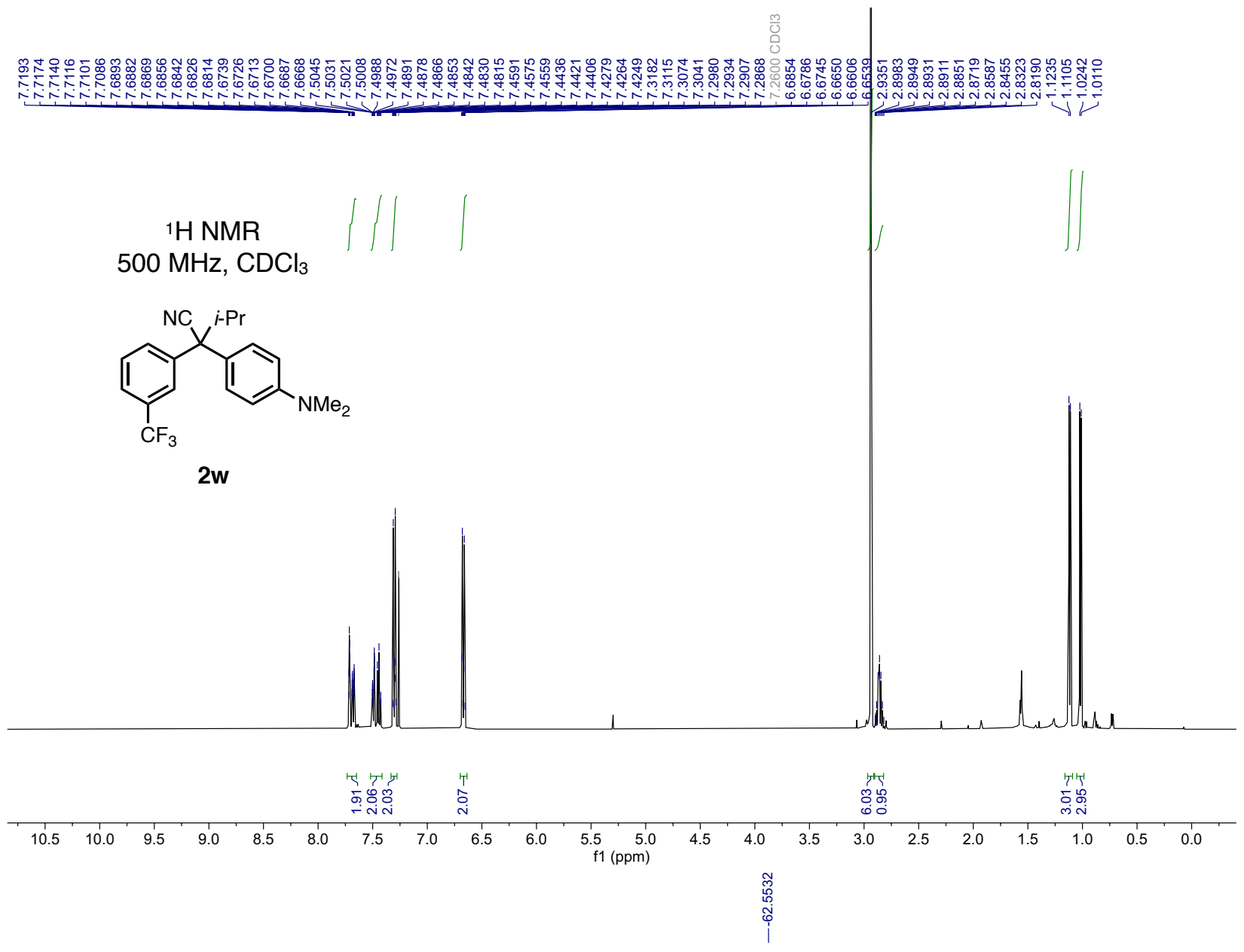

${ }^{19} \mathrm{~F}\left\{{ }^{1} \mathrm{H}\right\}$ NMR

$376 \mathrm{MHz}, \mathrm{CDCl}_{3}$<smiles>CCCC(C#N)(c1ccc(N(C)C)cc1)c1cccc(C(F)(F)F)c1</smiles>

2w

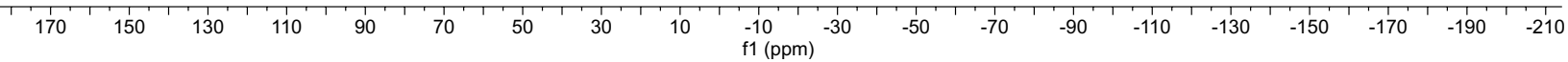




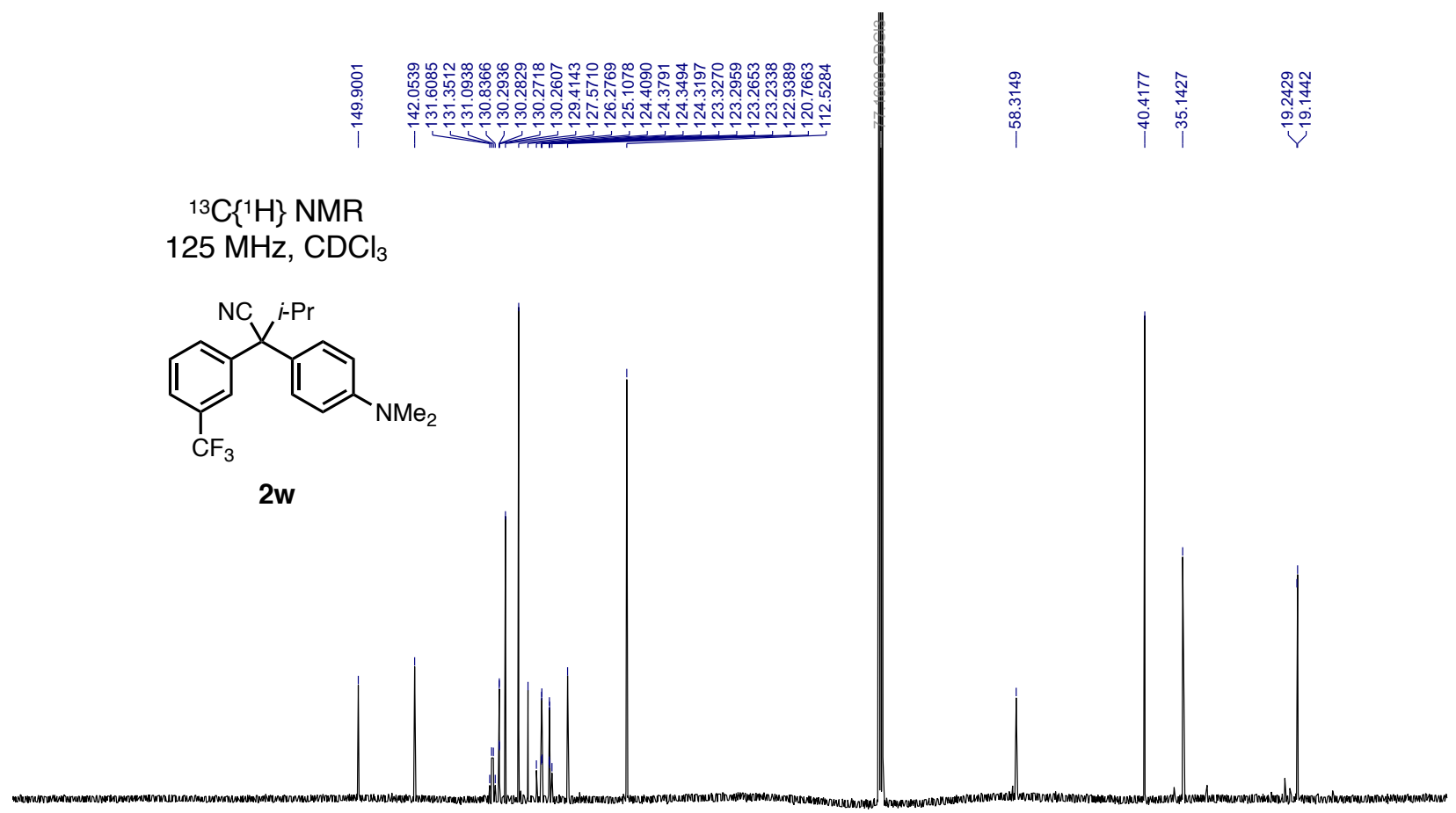

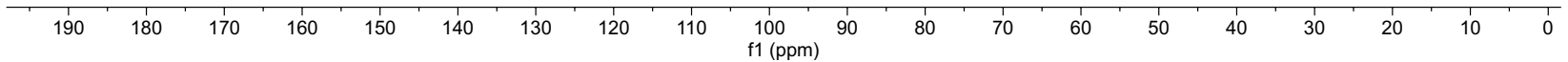




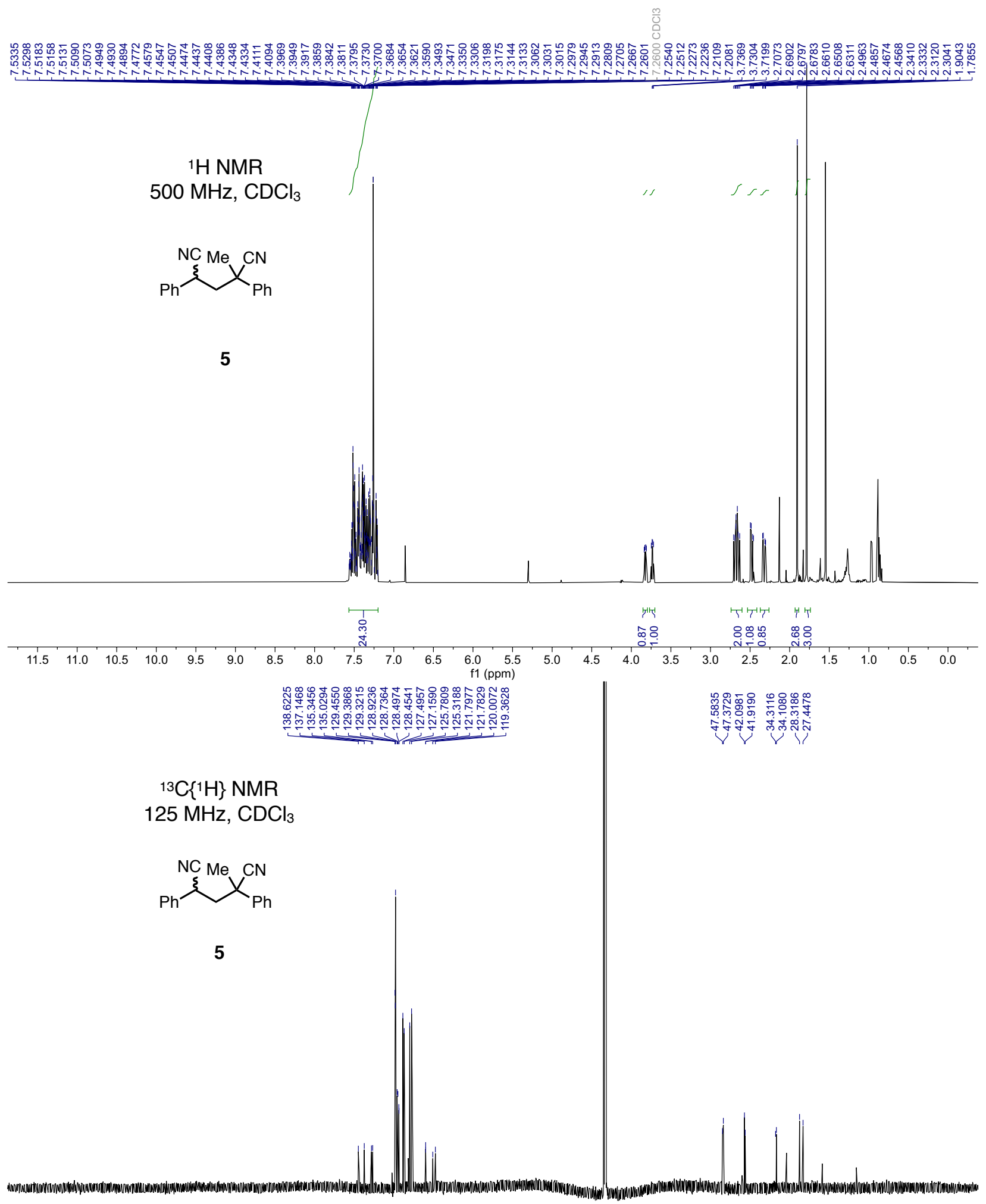

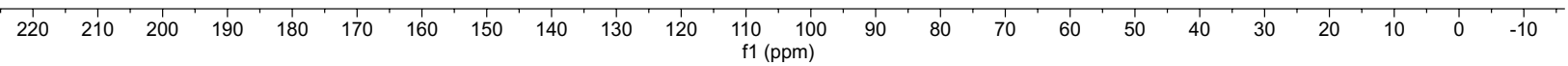


${ }^{1} \mathrm{H}$ NMR

$400 \mathrm{MHz}, \mathrm{CDCl}_{3}$<smiles>N#CC(C#N)c1ccccc1</smiles>

S11

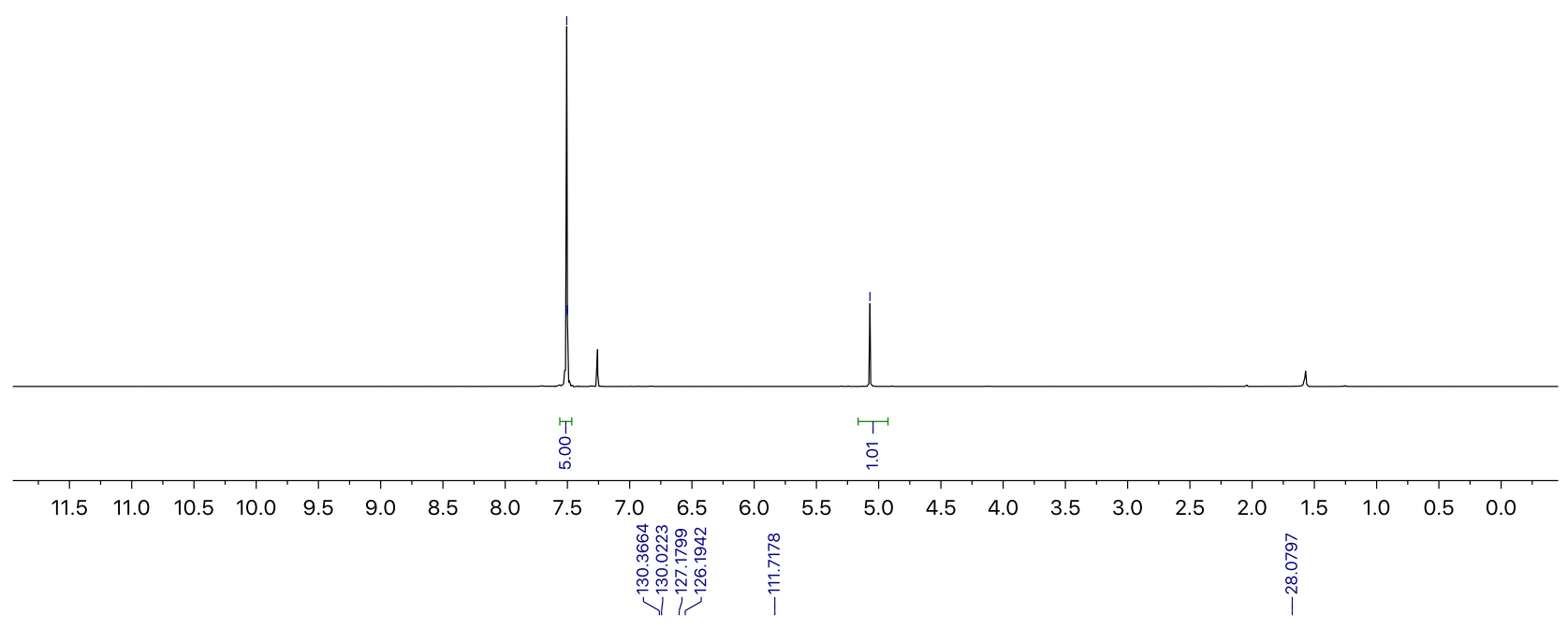

${ }^{13} \mathrm{C}\left\{{ }^{1} \mathrm{H}\right\}$ NMR

$100 \mathrm{MHz}, \mathrm{CDCl}_{3}$<smiles>N#CC(C#N)c1ccccc1</smiles>

S11

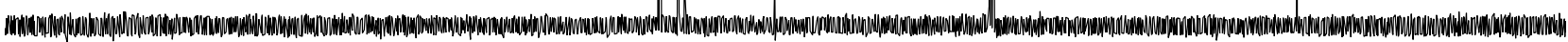

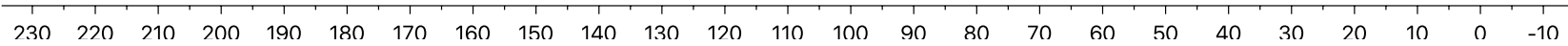




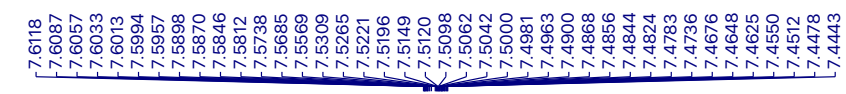

$1 \mathrm{H}$ NMR

$400 \mathrm{MHz}, \mathrm{CDCl}_{3}$<smiles>CC(C#N)(C#N)c1ccccc1</smiles>

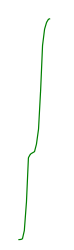

$4 a$

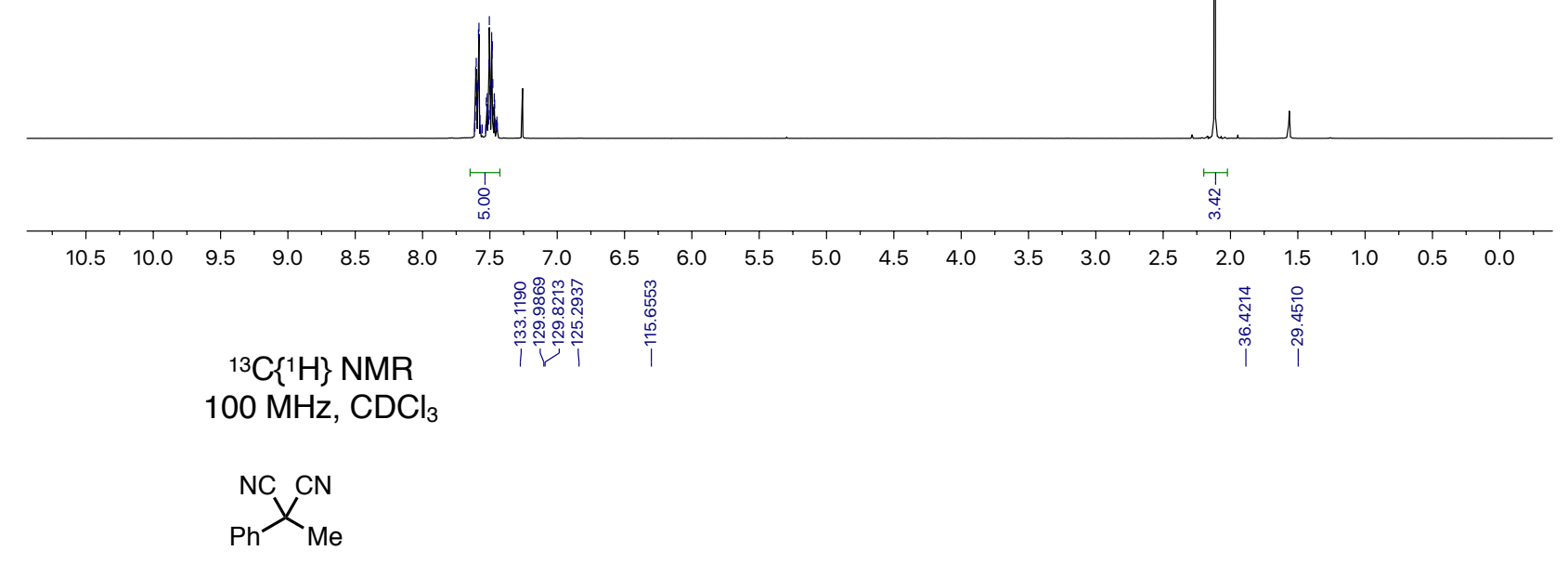

$4 a$

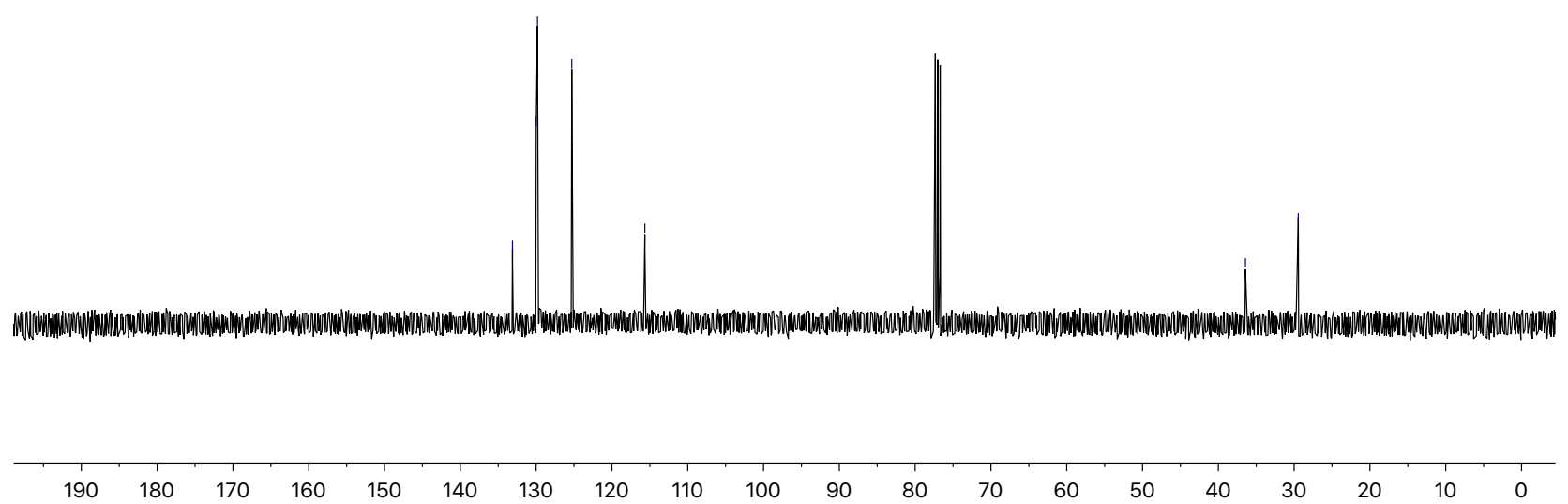




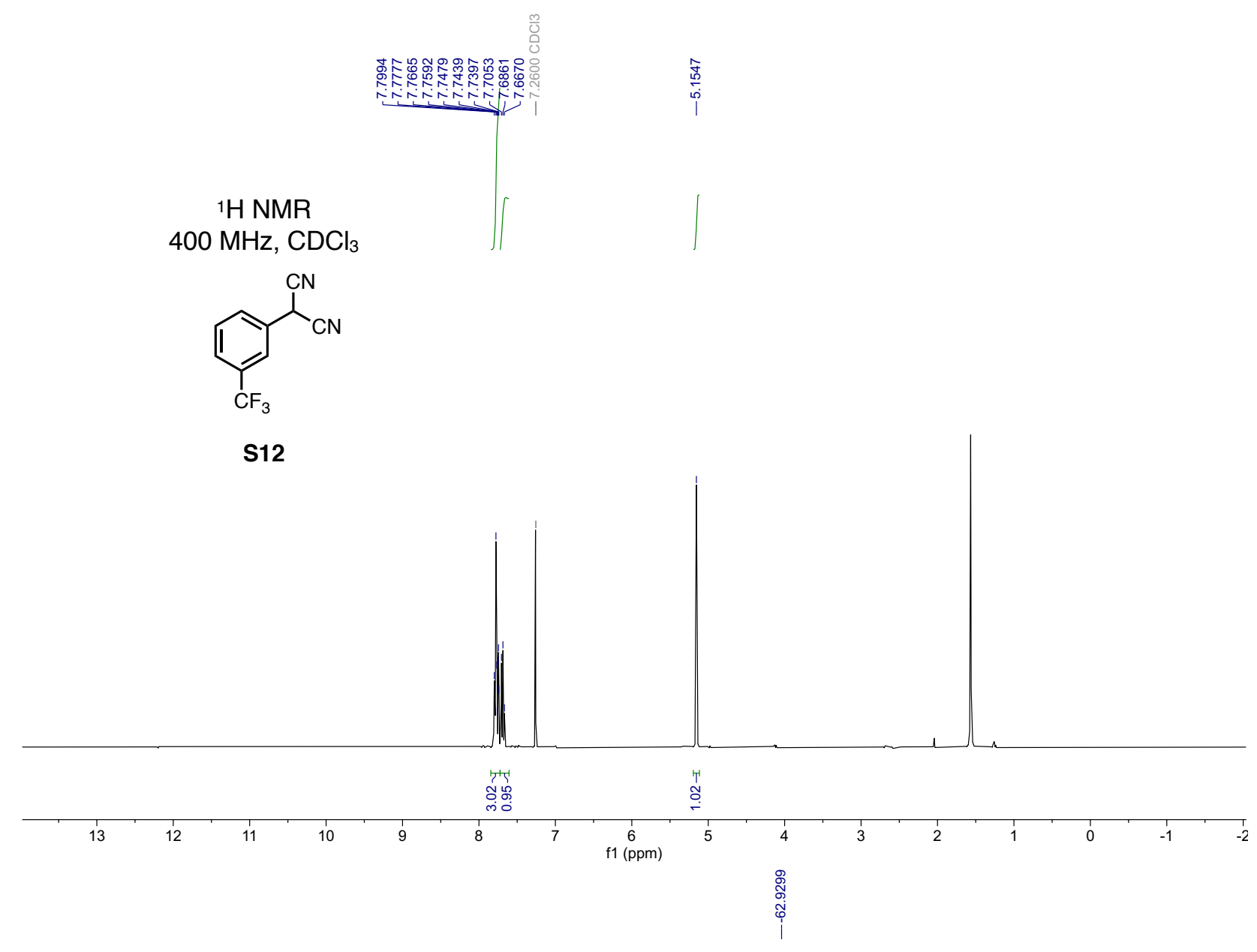

${ }^{19} \mathrm{~F}\left\{{ }^{1} \mathrm{H}\right\}$ NMR

$376 \mathrm{MHz}, \mathrm{CDCl}_{3}$

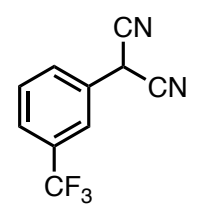

S12

\begin{tabular}{lllllllllllllllllllllll}
\hline 170 & 150 & 130 & 110 & 90 & 70 & 50 & 30 & 10 & -10 & -30 & -50 & -70 & -90 & -110 & -130 & -150 & -170 & -190 & -210
\end{tabular}




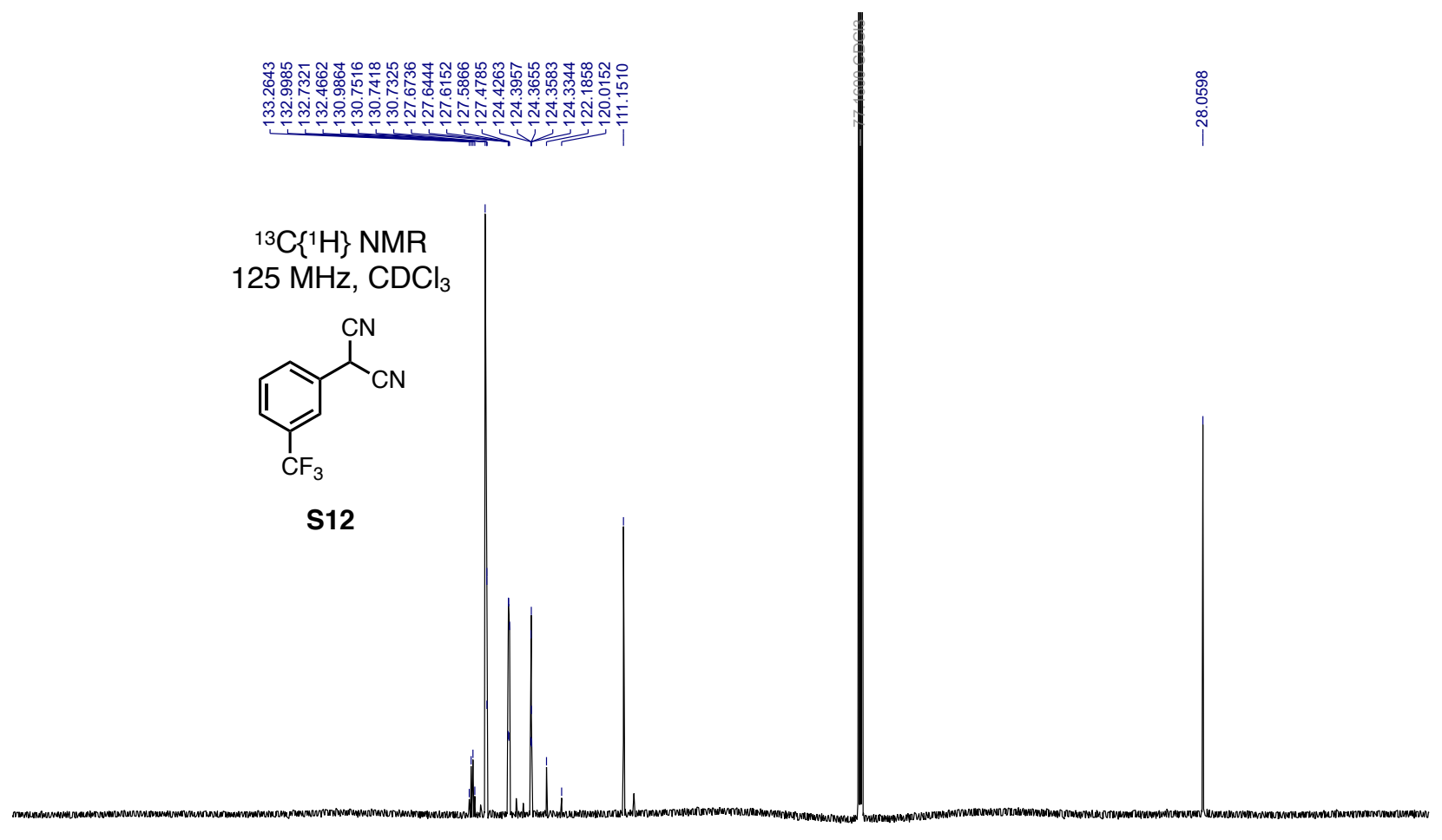

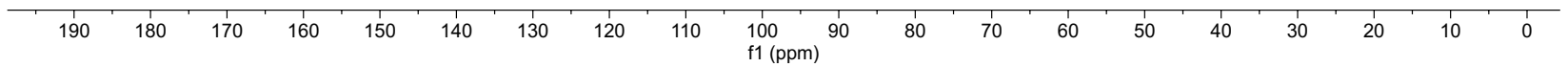




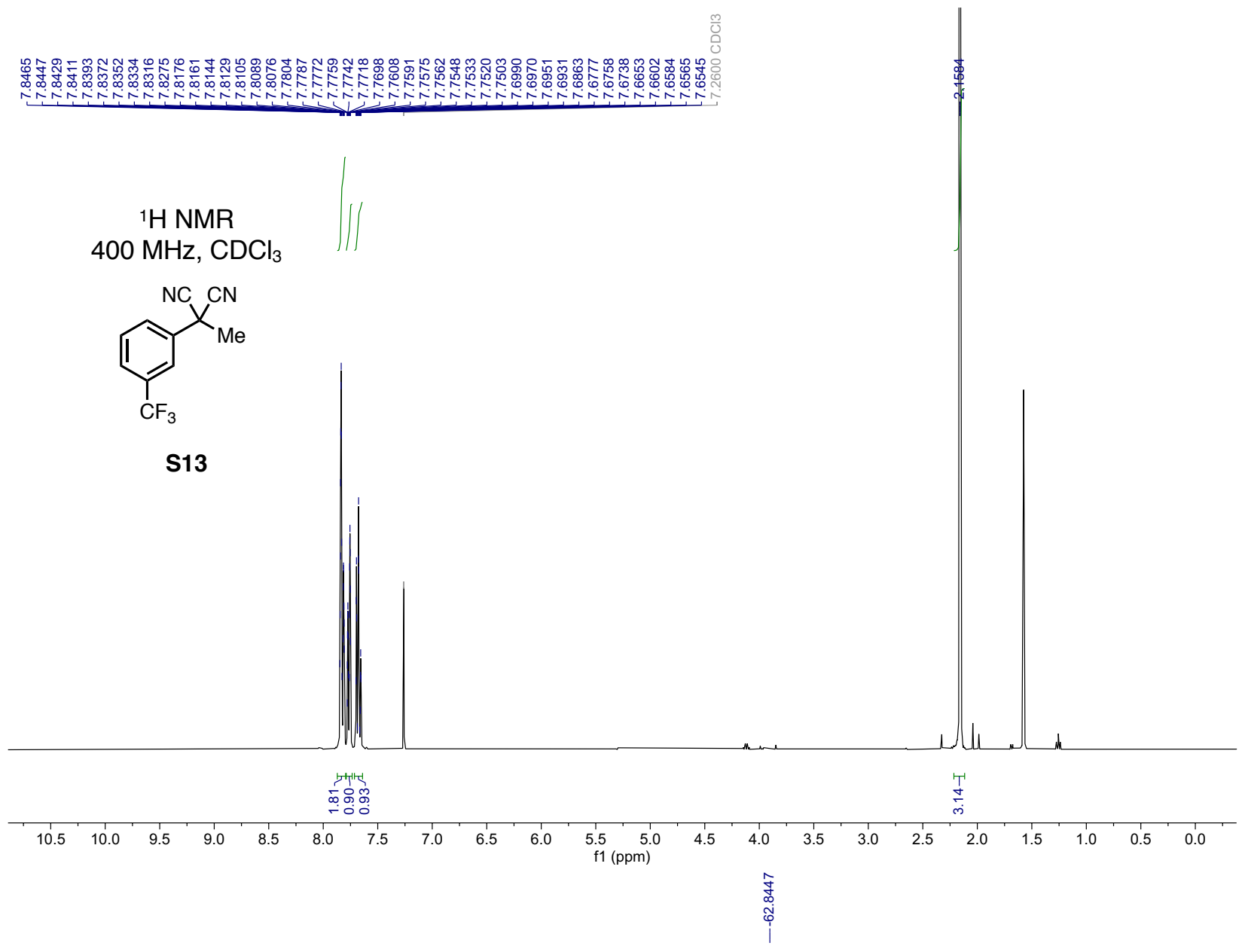

${ }^{19} \mathrm{~F}\left\{{ }^{1} \mathrm{H}\right\}$ NMR

$376 \mathrm{MHz}, \mathrm{CDCl}_{3}$<smiles>CC(C)(C#N)c1cccc(C(F)(F)F)c1</smiles>

S13

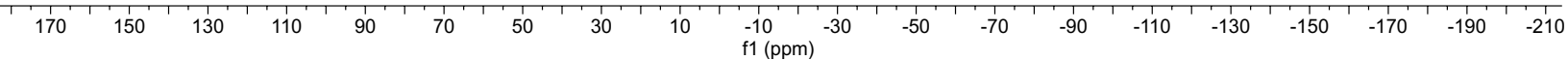




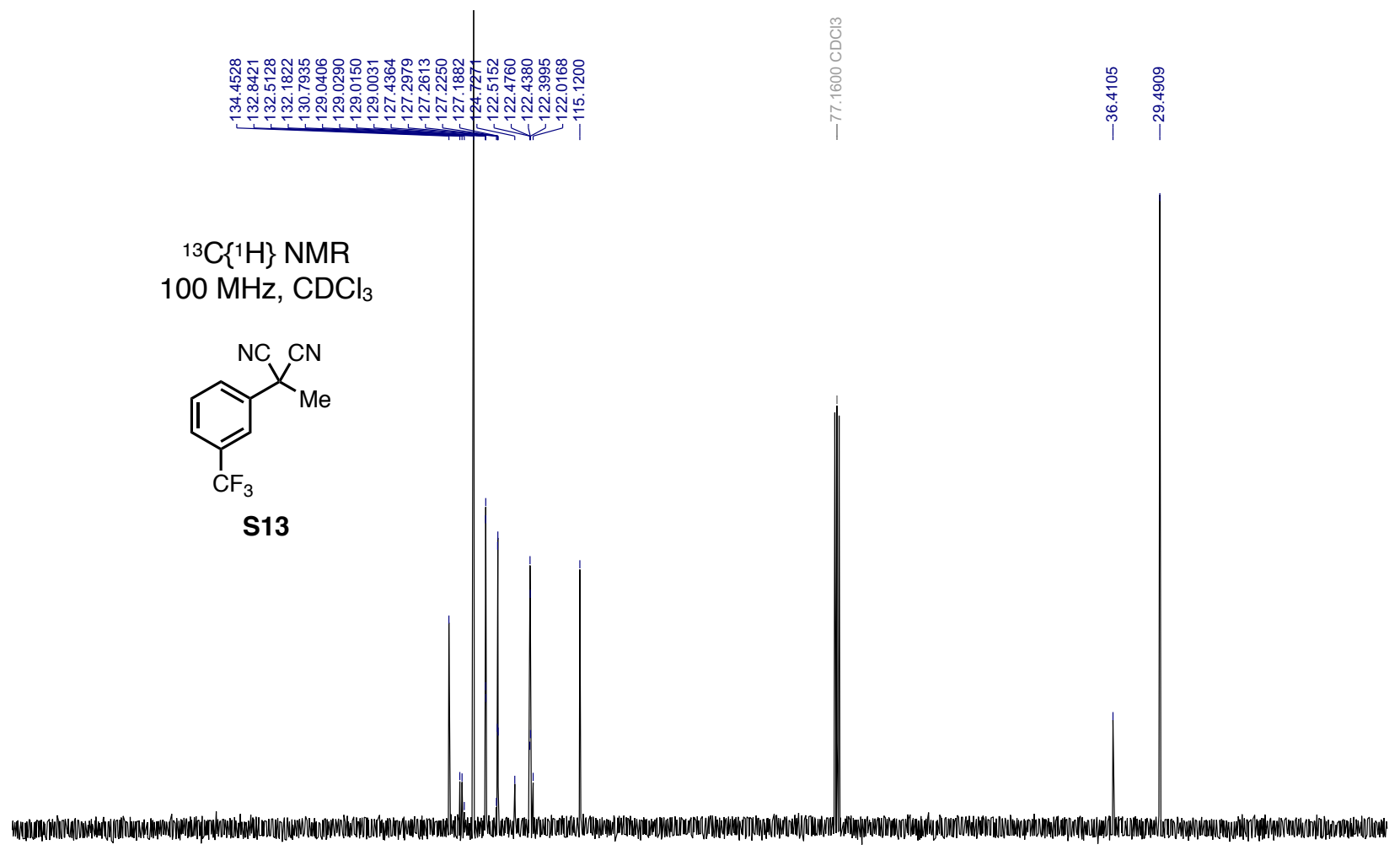

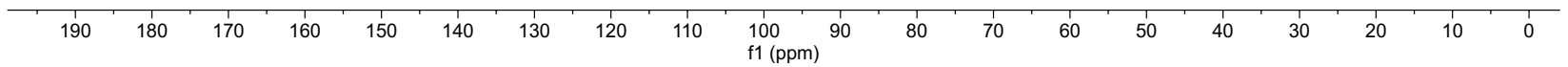




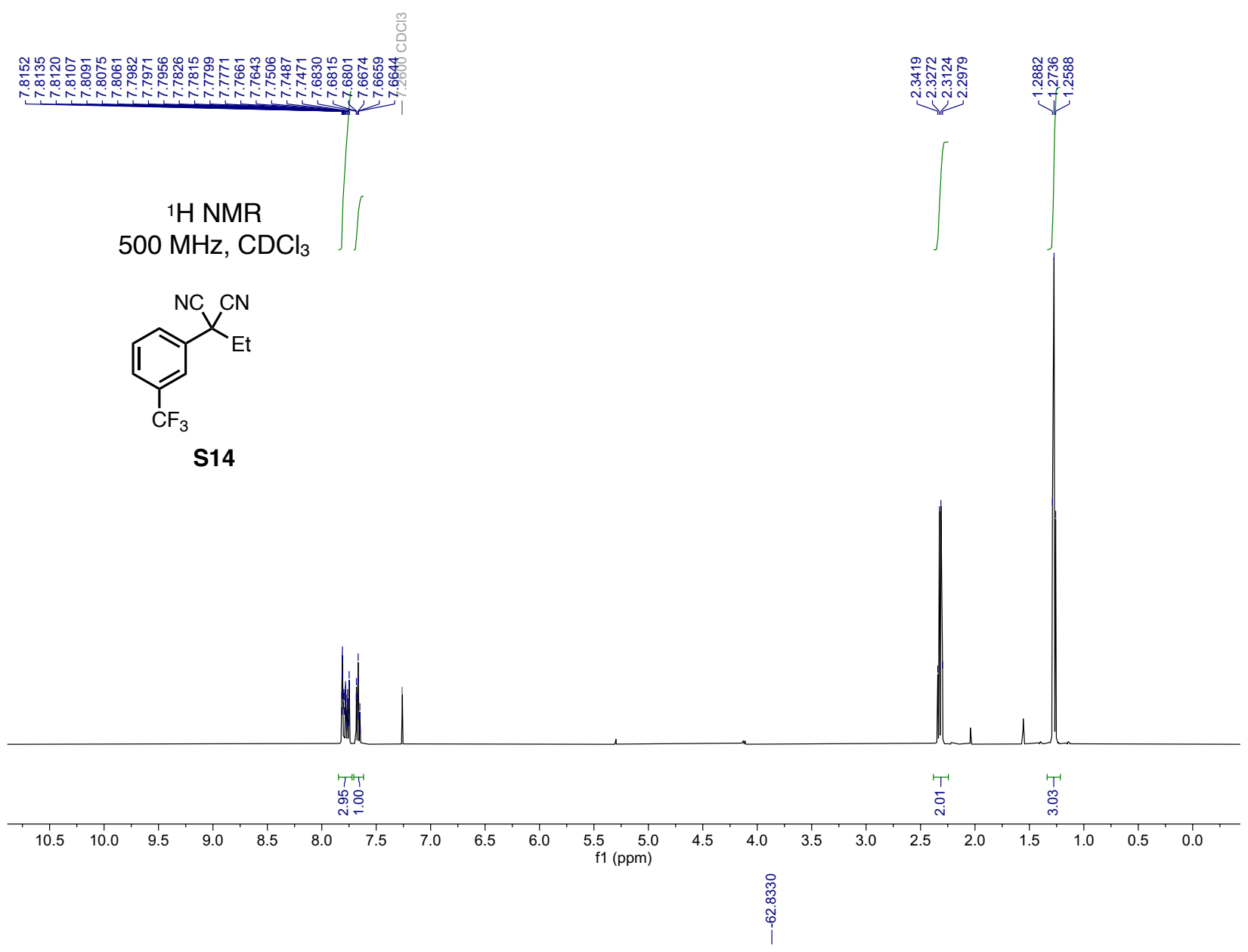

${ }^{19} \mathrm{~F}\left\{{ }^{1} \mathrm{H}\right\}$ NMR

$376 \mathrm{MHz}, \mathrm{CDCl}_{3}$<smiles>CCC(C)(C#N)c1cccc(C(F)(F)F)c1</smiles>

S14

$\begin{array}{llllllllllllllllllllllllllllll}170 & 150 & 130 & 110 & 90 & 70 & 50 & 30 & 10 & -10 & -30 & -50 & -70 & -90 & -110 & -130 & -150 & -170 & -190 & -210\end{array}$




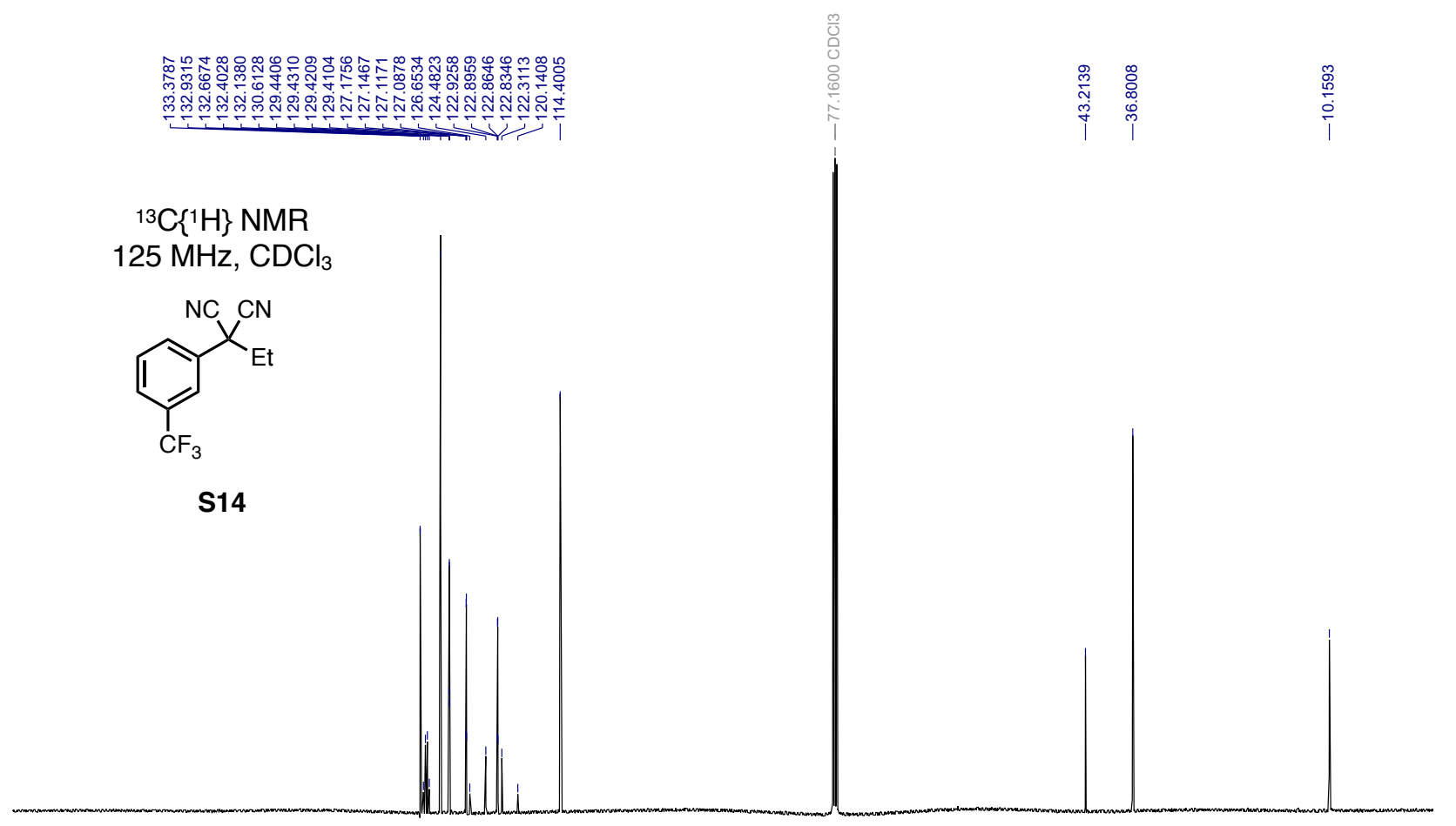

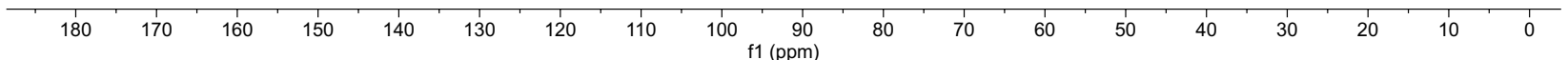



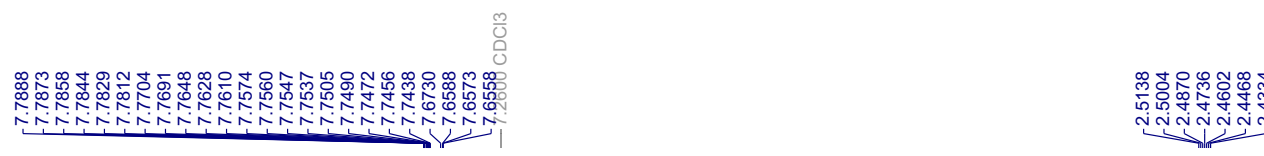

${ }^{1} \mathrm{H}$ NMR

$500 \mathrm{MHz}, \mathrm{CDCl}_{3}$<smiles>CC(C)C(C)(C#N)c1cccc(C(F)(F)F)c1</smiles>

S15

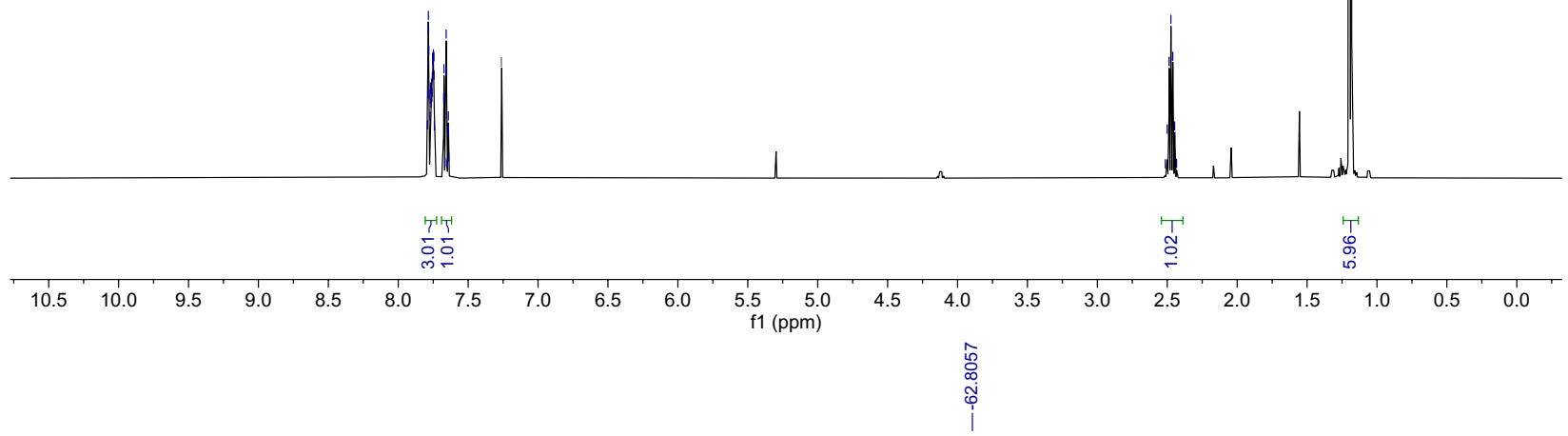

${ }^{19} \mathrm{~F}\left\{{ }^{1} \mathrm{H}\right\} \mathrm{NMR}$

$376 \mathrm{MHz}, \mathrm{CDCl}_{3}$<smiles>CC(C)C(C)(C#N)c1cccc(C(F)(F)F)c1</smiles>

S15

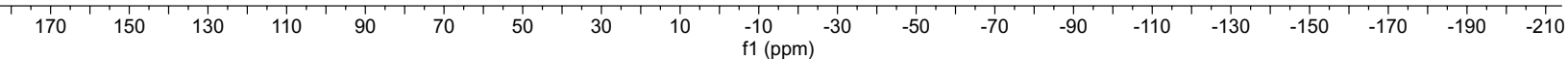


${ }^{13} \mathrm{C}\left\{{ }^{1} \mathrm{H}\right\} \mathrm{NMR}$ $125 \mathrm{MHz}, \mathrm{CDCl}_{3}$<smiles>CC(C)C(C)(C#N)c1cccc(C(F)(F)F)c1</smiles>
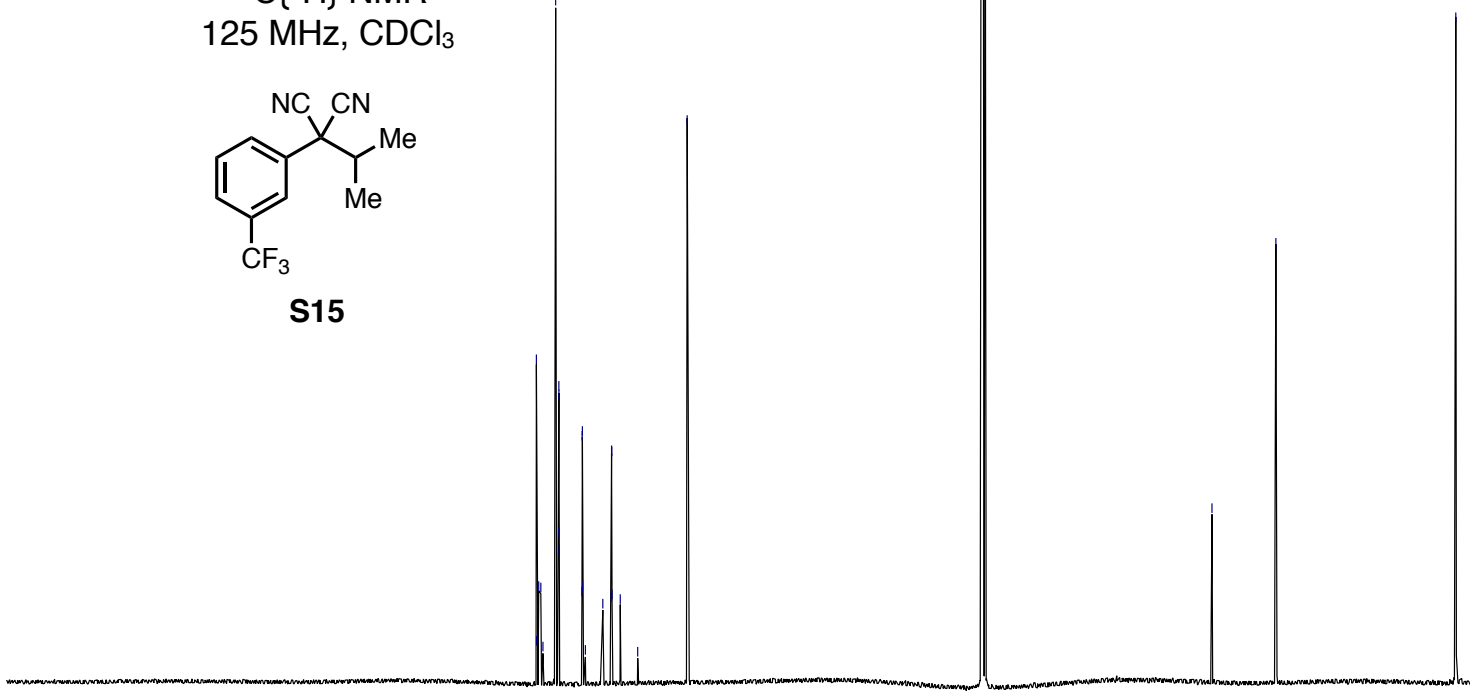

\begin{tabular}{lllllllllllllllllllll}
\hline 190 & 180 & 170 & 160 & 150 & 140 & 130 & 120 & 110 & $\begin{array}{l}100 \\
\mathrm{f} 1(\mathrm{ppm})\end{array}$ & 90 & 80 & 70 & 60 & 50 & 40 & 30 & 20 & 10 & 0
\end{tabular} 


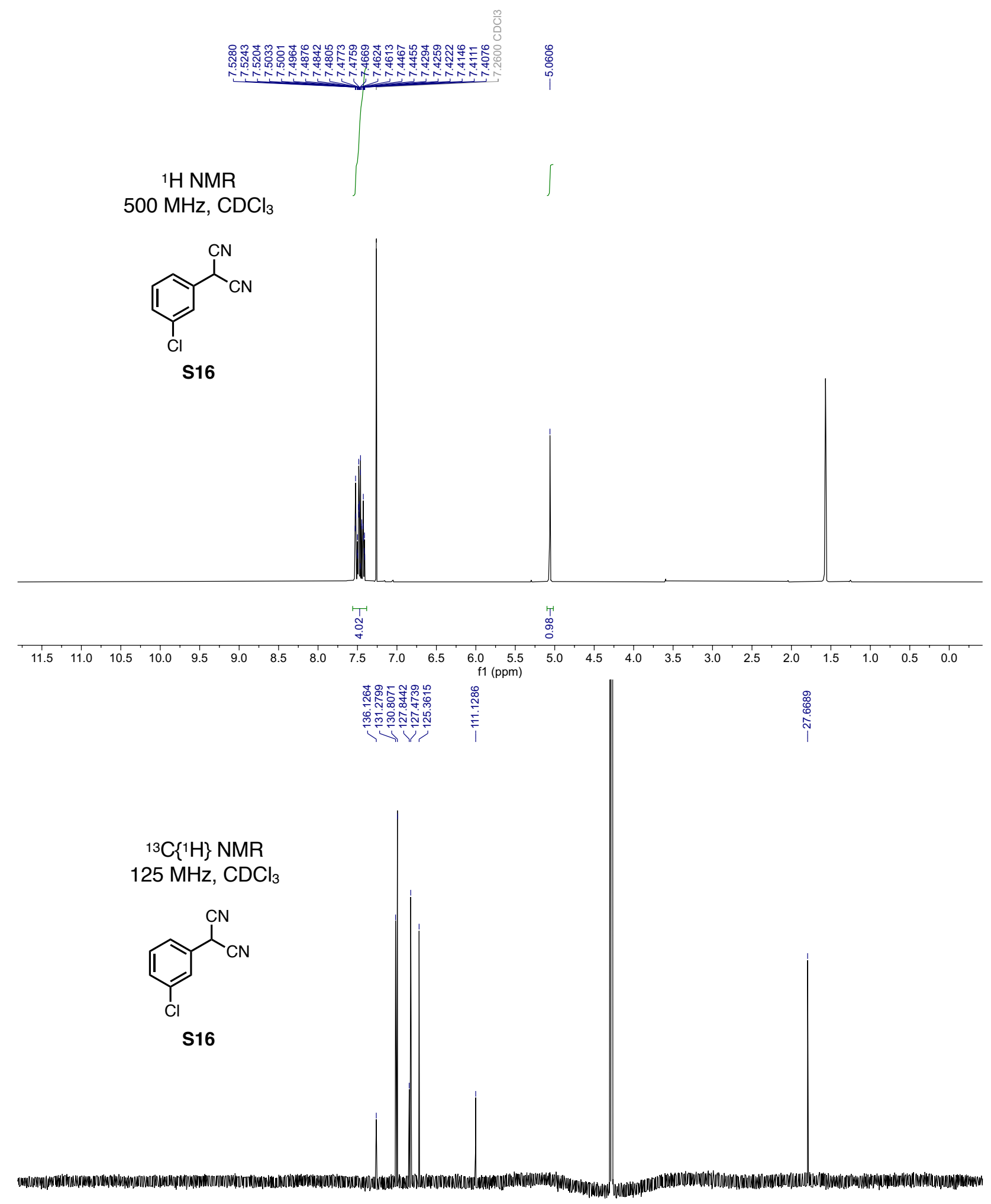

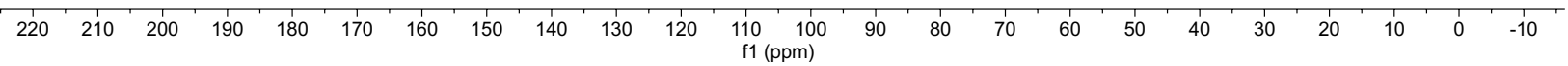




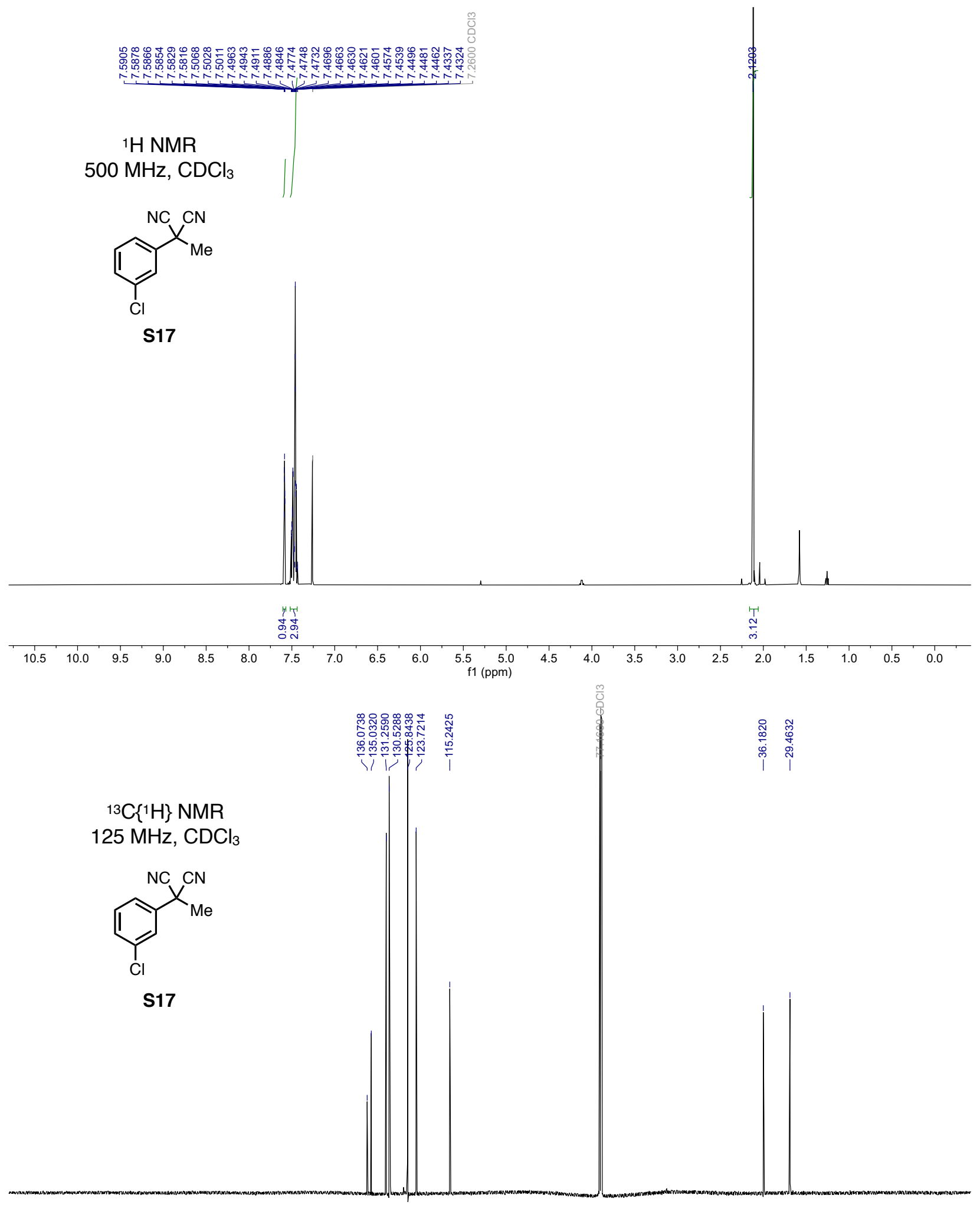

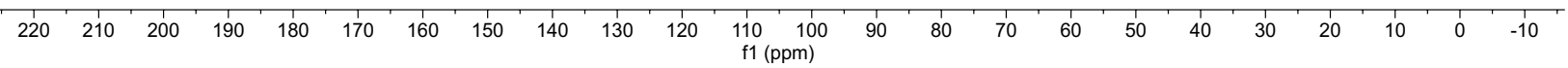




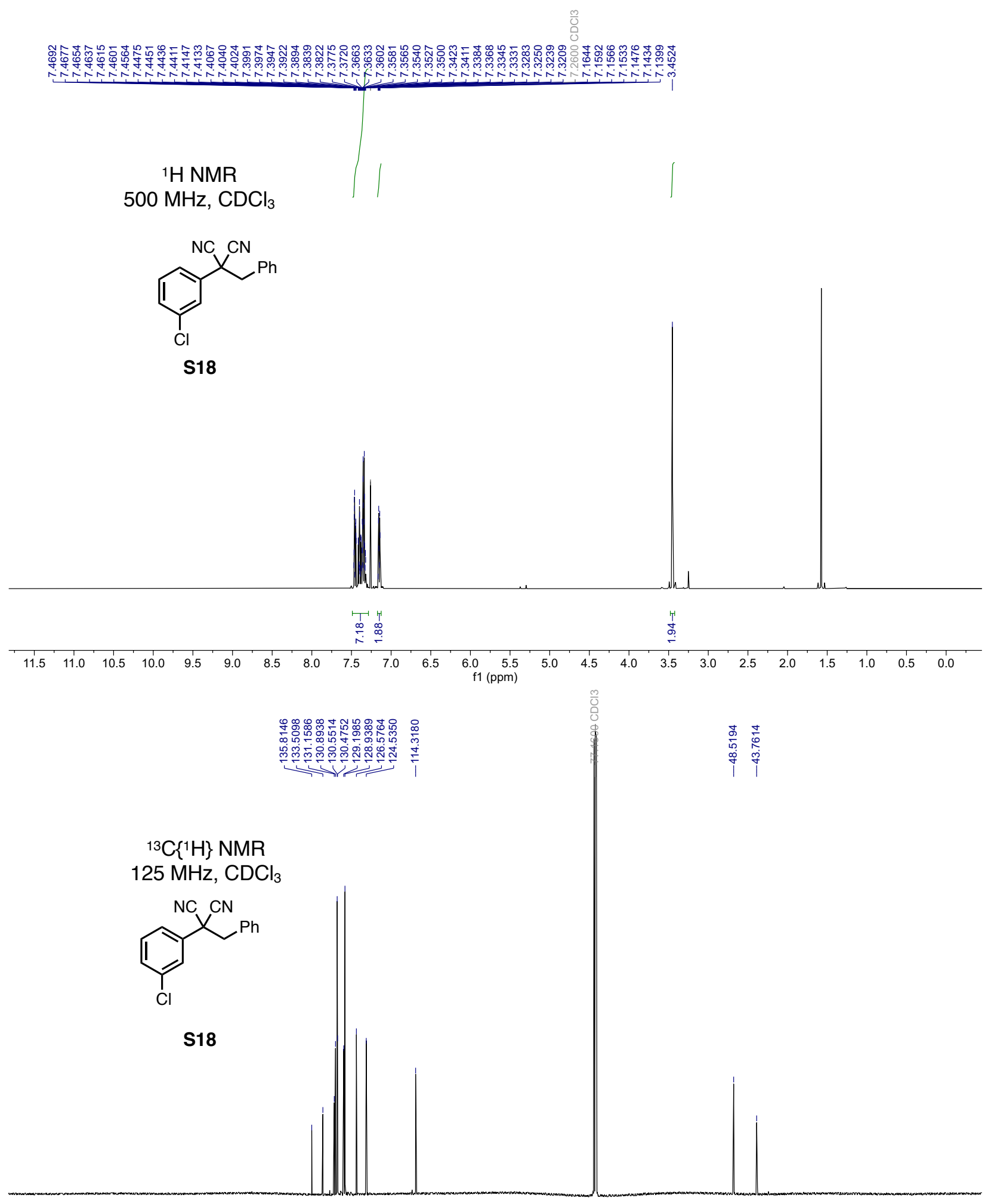

\begin{tabular}{|c|c|c|c|c|c|c|c|c|c|c|c|c|c|c|c|c|c|c|c|}
\hline 190 & 180 & 170 & 160 & 150 & 140 & 130 & 120 & 110 & $\begin{array}{l}100 \\
\mathrm{f} 1(\mathrm{ppm})\end{array}$ & 90 & 80 & 70 & 60 & 50 & 40 & 30 & 20 & 10 & 0 \\
\hline
\end{tabular}




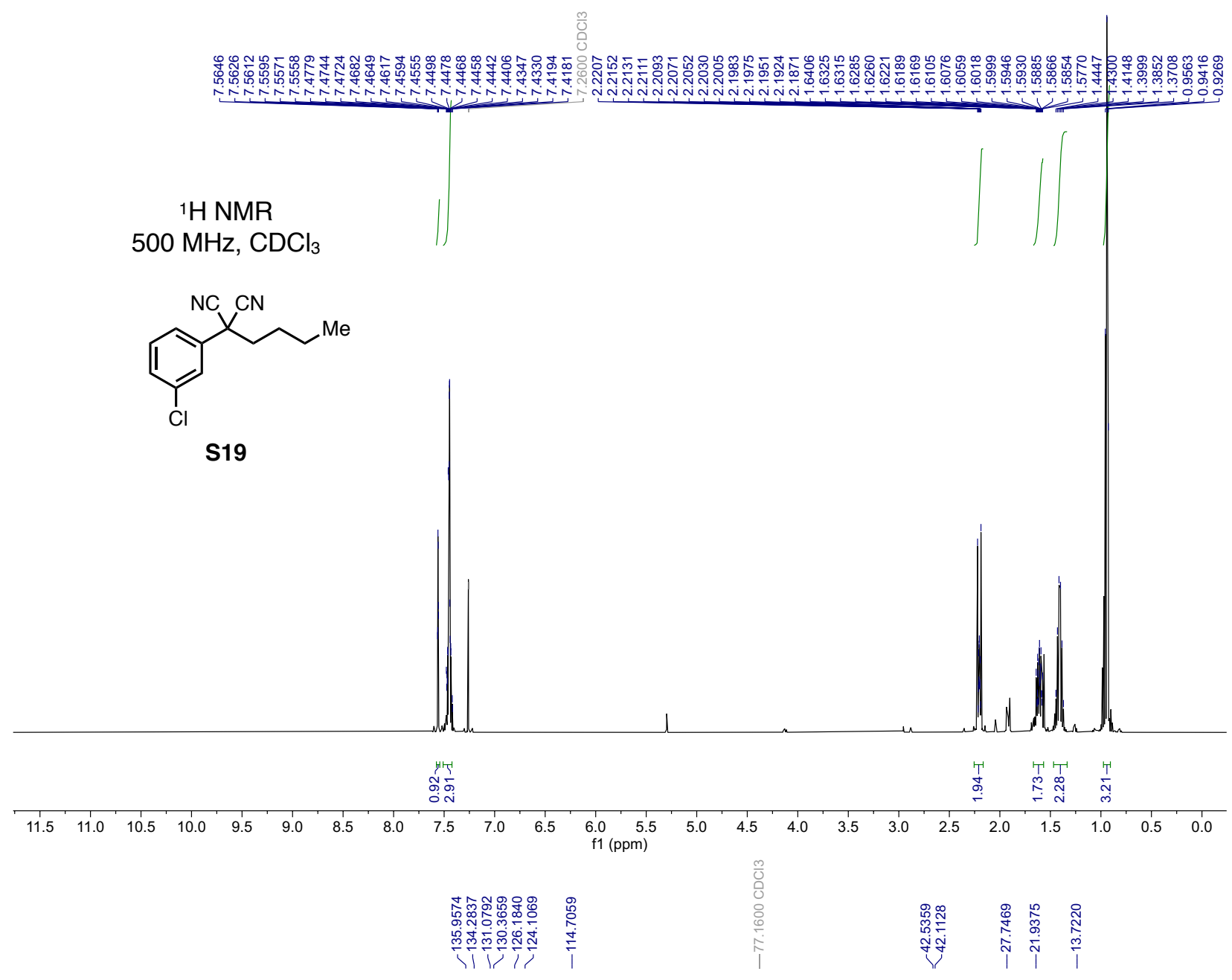

${ }^{13} \mathrm{C}\left\{{ }^{1} \mathrm{H}\right\}$ NMR

$125 \mathrm{MHz}, \mathrm{CDCl}_{3}$<smiles>CCCCC(C)(C#N)c1cccc(Cl)c1</smiles>

S19

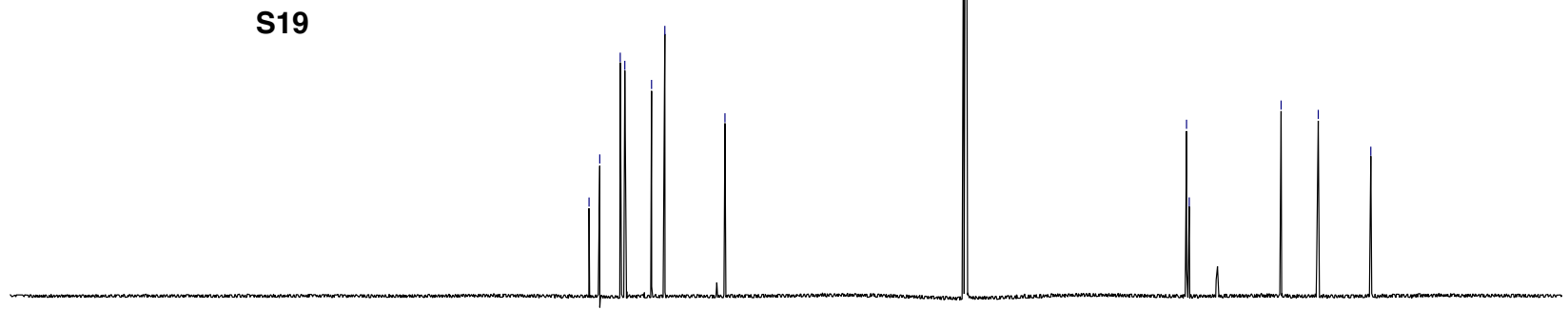

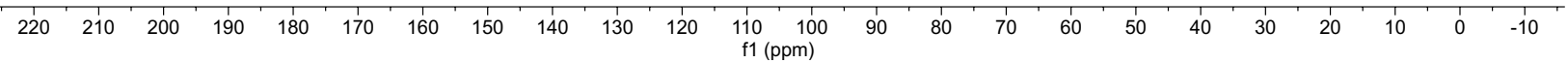



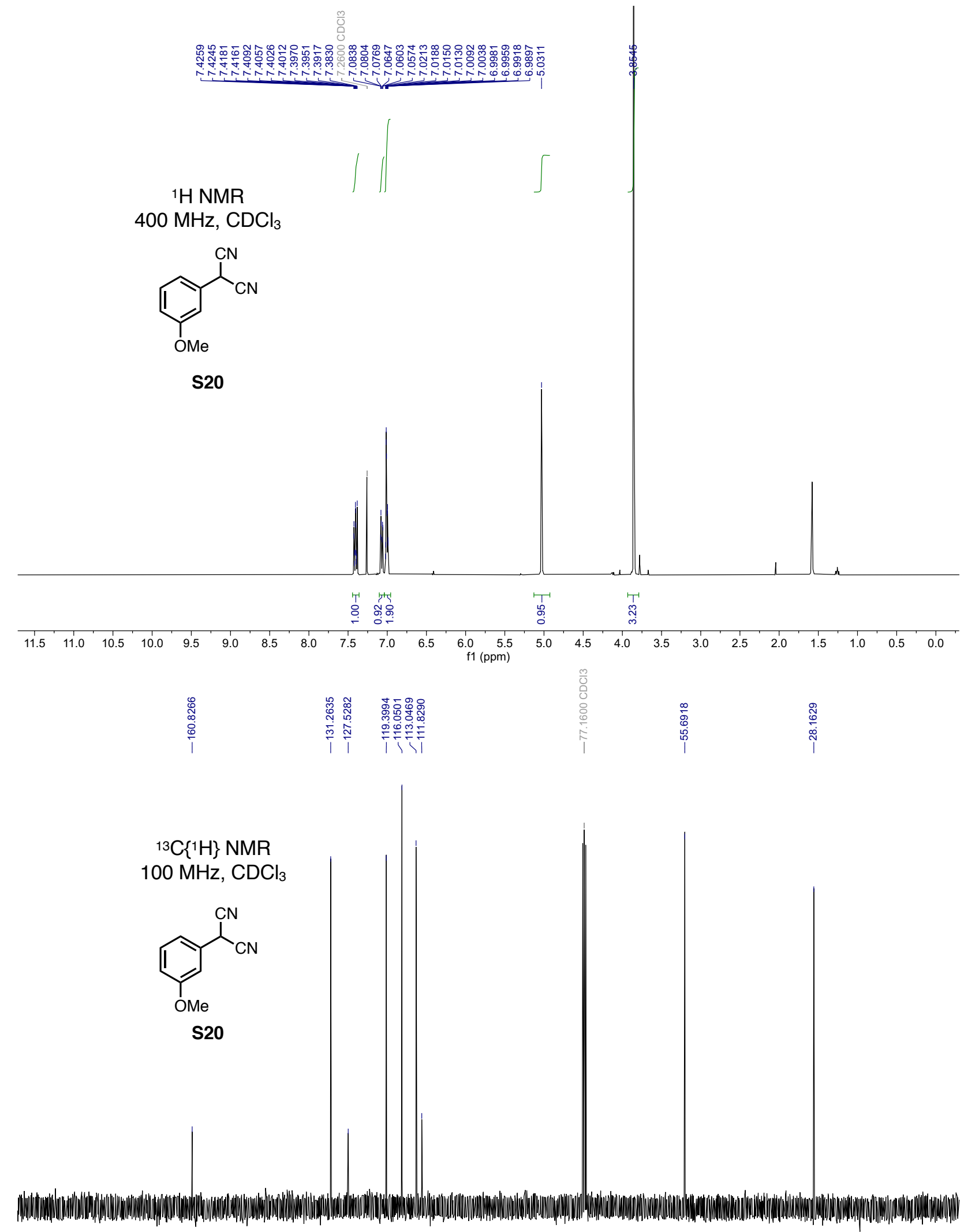

\begin{tabular}{|c|c|c|c|c|c|c|c|c|c|c|c|c|c|c|c|c|c|c|c|}
\hline 190 & 180 & 170 & 160 & 150 & 140 & 130 & 120 & 110 & $\begin{array}{l}100 \\
\mathrm{f} 1 \text { (ppm) }\end{array}$ & 90 & 80 & 70 & 60 & 50 & 40 & 30 & 20 & 10 & 0 \\
\hline
\end{tabular}



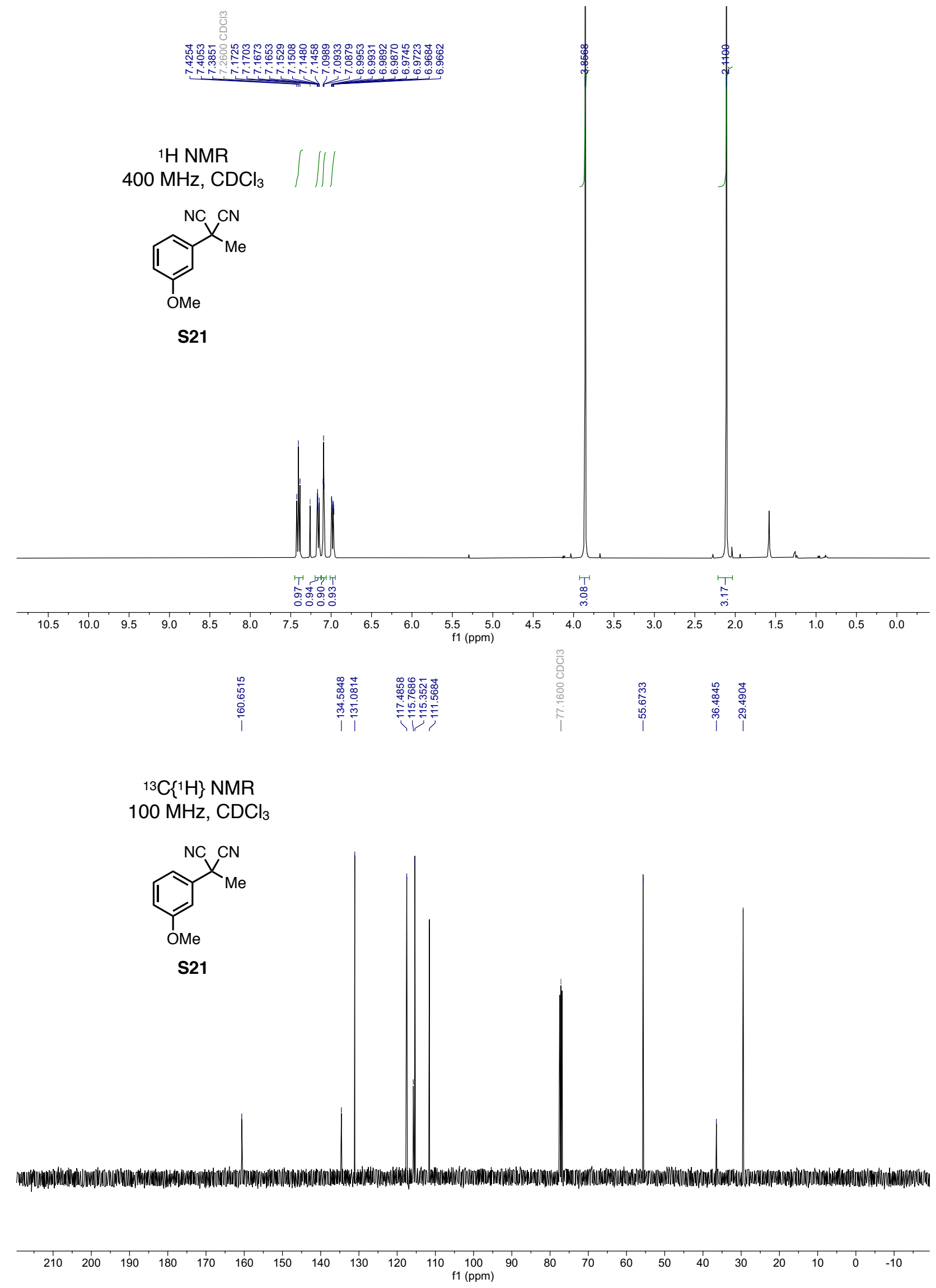


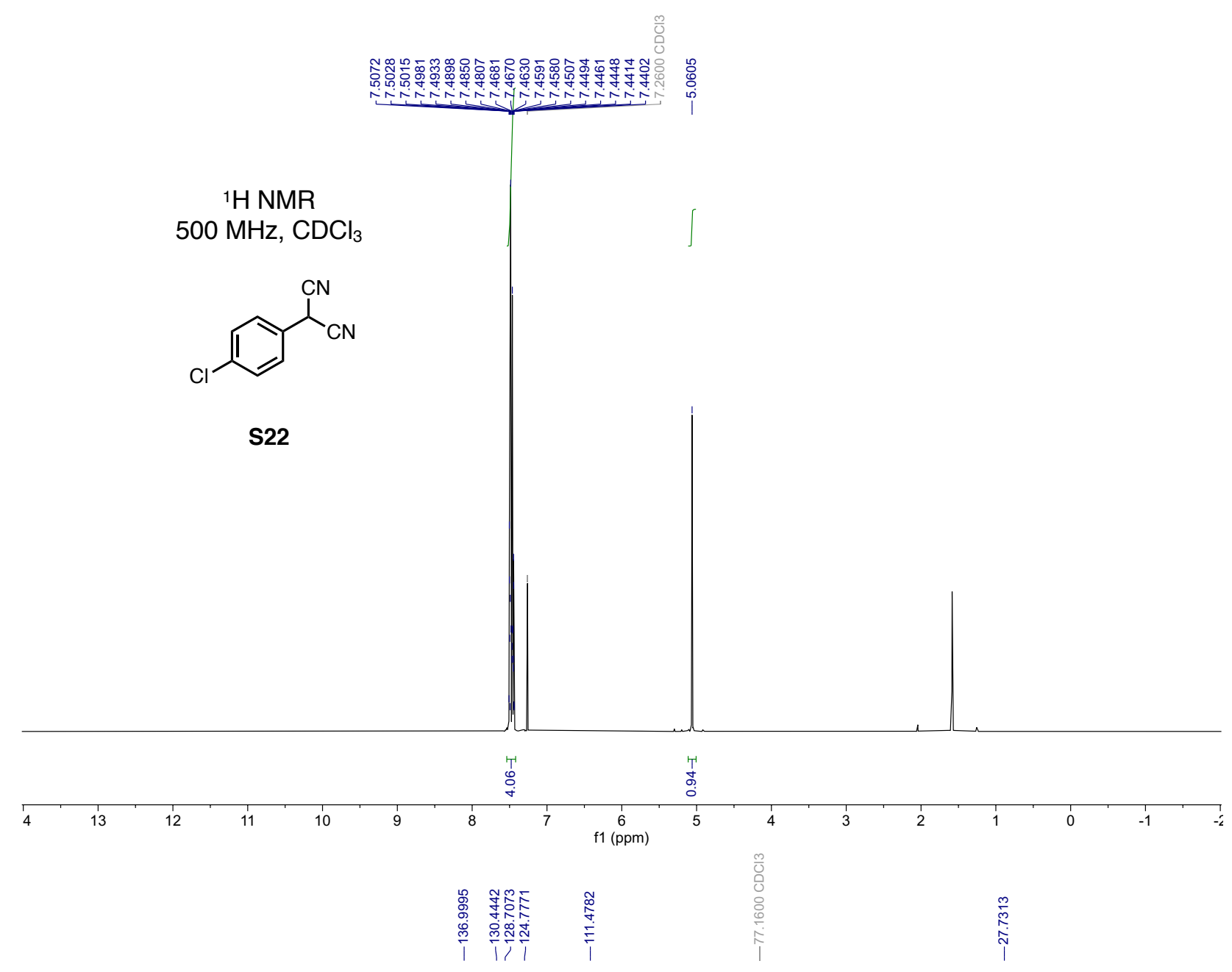

${ }^{13} \mathrm{C}\left\{{ }^{1} \mathrm{H}\right\}$ NMR

$125 \mathrm{MHz}, \mathrm{CDCl}_{3}$

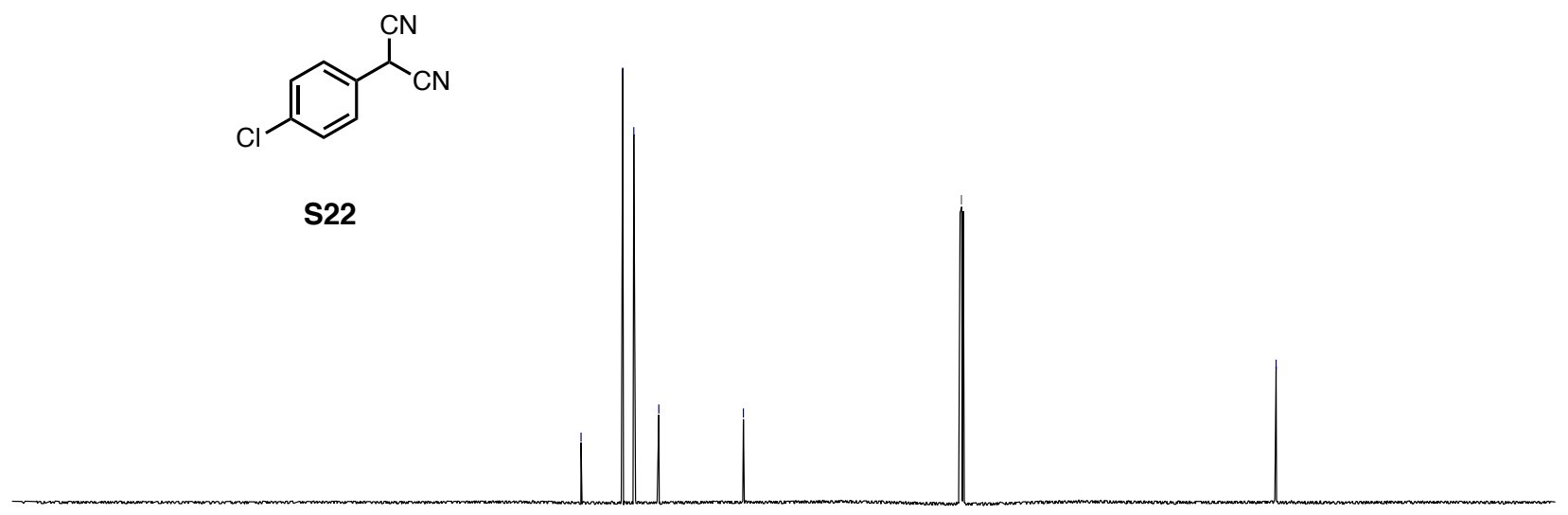

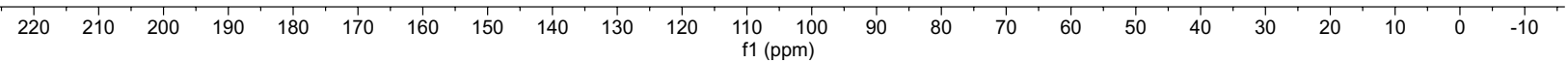


$1 \mathrm{H}$ NMR $500 \mathrm{MHz}, \mathrm{CDCl}_{3}$<smiles>CC(C)(C#N)c1ccc(Cl)cc1</smiles>

S23

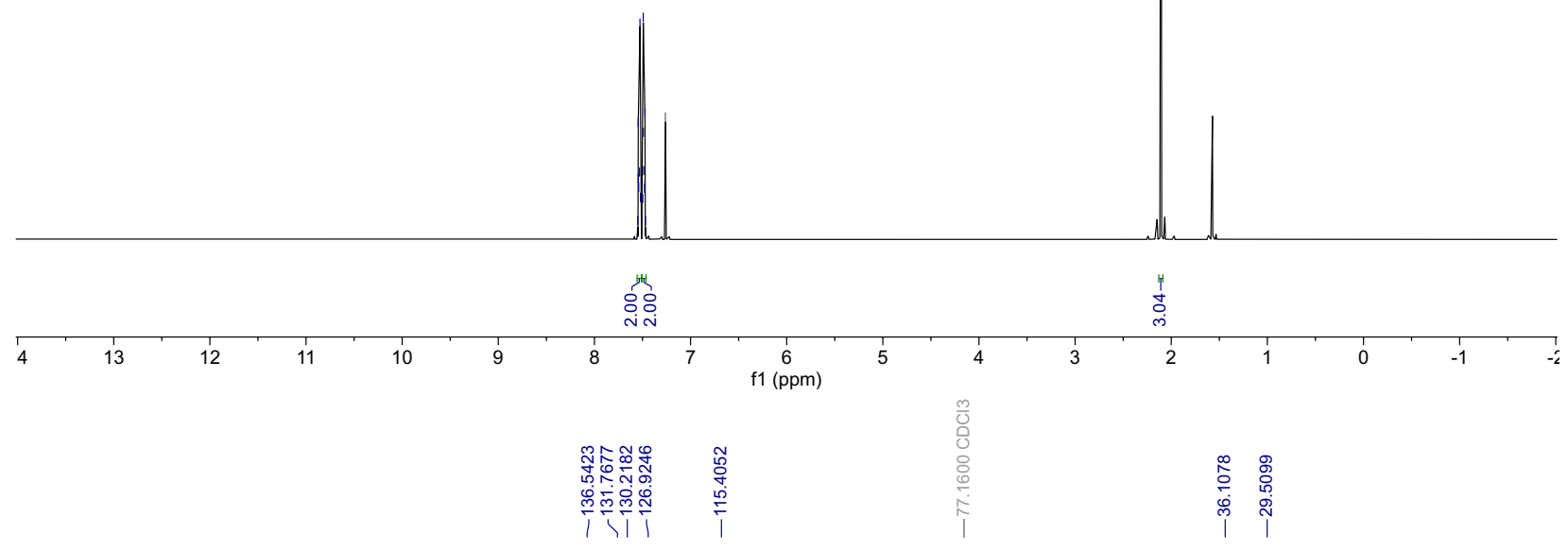

${ }^{13} \mathrm{C}\left\{{ }^{1} \mathrm{H}\right\}$ NMR

$125 \mathrm{MHz}, \mathrm{CDCl}_{3}$<smiles>CC(C#N)(C#N)c1ccc(Cl)cc1</smiles>

S23
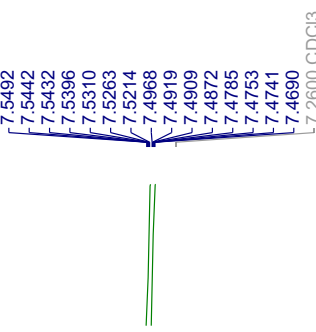


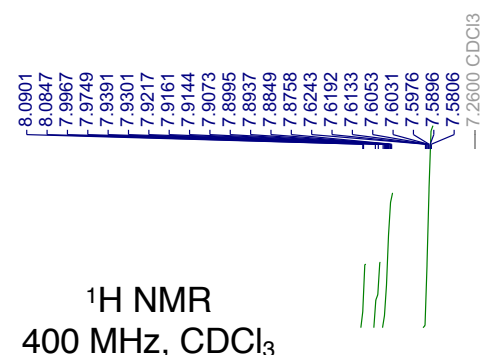

$400 \mathrm{MHz}, \mathrm{CDCl}_{3}$<smiles>CC(C)(C#N)c1ccc2ccccc2c1</smiles>

S25

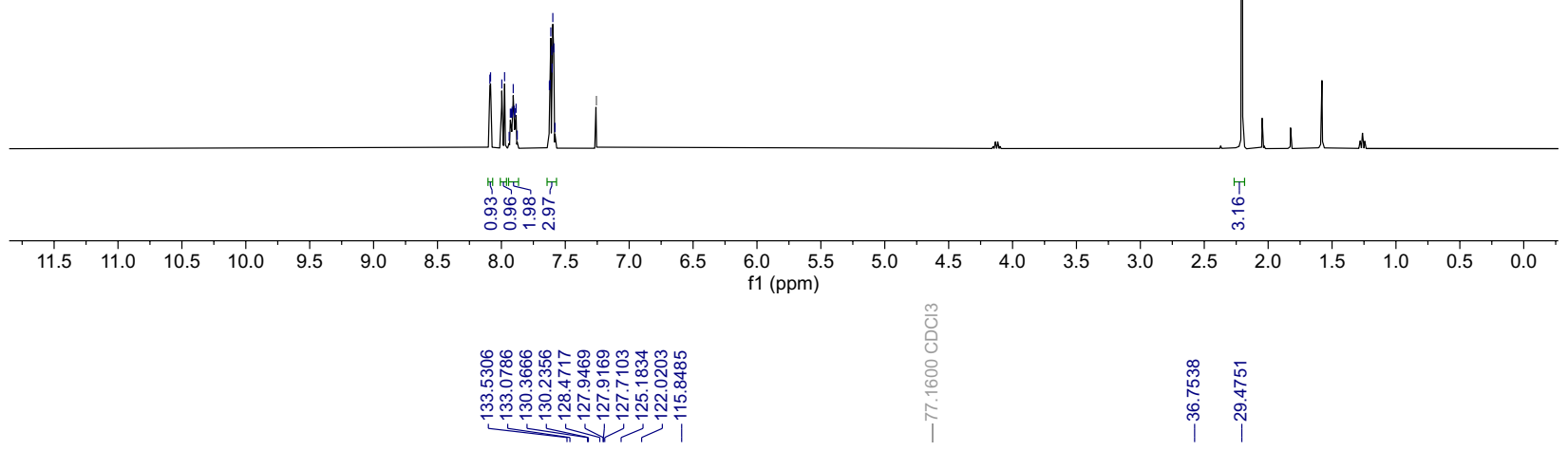

${ }^{13} \mathrm{C}\left\{{ }^{1} \mathrm{H}\right\}$ NMR

$100 \mathrm{MHz}, \mathrm{CDCl}_{3}$<smiles>CC(C)(C#N)c1ccc2ccccc2c1</smiles>

S25

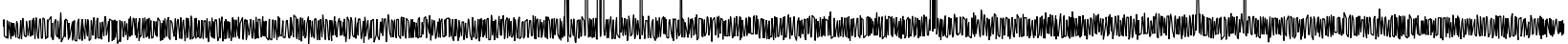

$\begin{array}{lllllllllllllllllllllllll}210 & 200 & 190 & 180 & 170 & 160 & 150 & 140 & 130 & 120 & 110 & \begin{array}{c}100 \\ \mathrm{f} 1(\mathrm{ppm})\end{array} & 90 & 80 & 70 & 60 & 50 & 40 & 30 & 20 & 10 & 0 & -10\end{array}$


$1 \mathrm{H}$ NMR

$400 \mathrm{MHz} \mathrm{CDCl}_{3}$<smiles>CC(C)(C)c1ccc(C(C#N)C#N)cc1</smiles>

S26

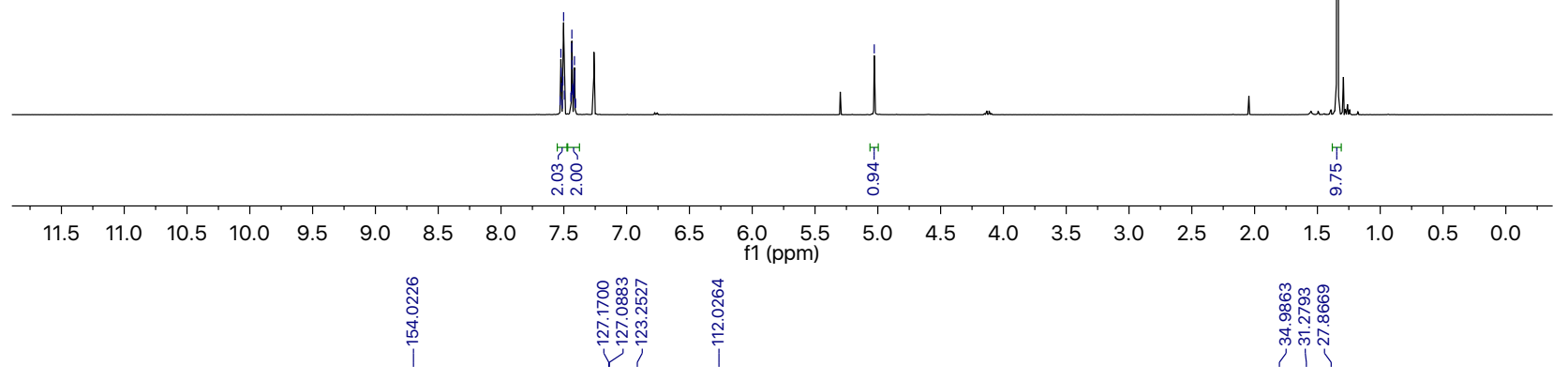

${ }^{13} \mathrm{C}\left\{{ }^{1} \mathrm{H}\right\}$ NMR

$100 \mathrm{MHz} \mathrm{CDCl}_{3}$<smiles>CC(C)(C)c1ccc(C(C#N)C#N)cc1</smiles>

S26

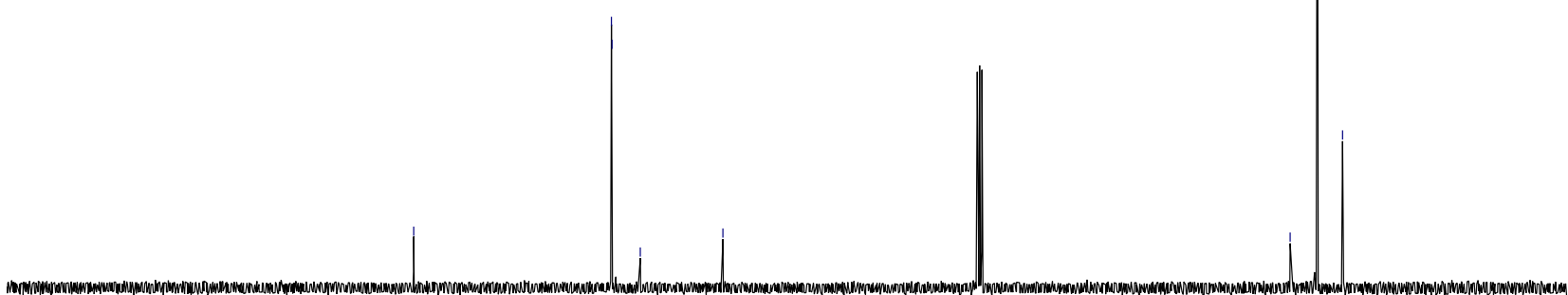

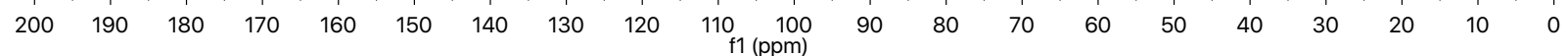


$1 \mathrm{H}$ NMR

$400 \mathrm{MHz}, \mathrm{CDCl}_{3}$<smiles>CC(C)(C)c1ccc(C(C)(C)C#N)cc1</smiles>

S27

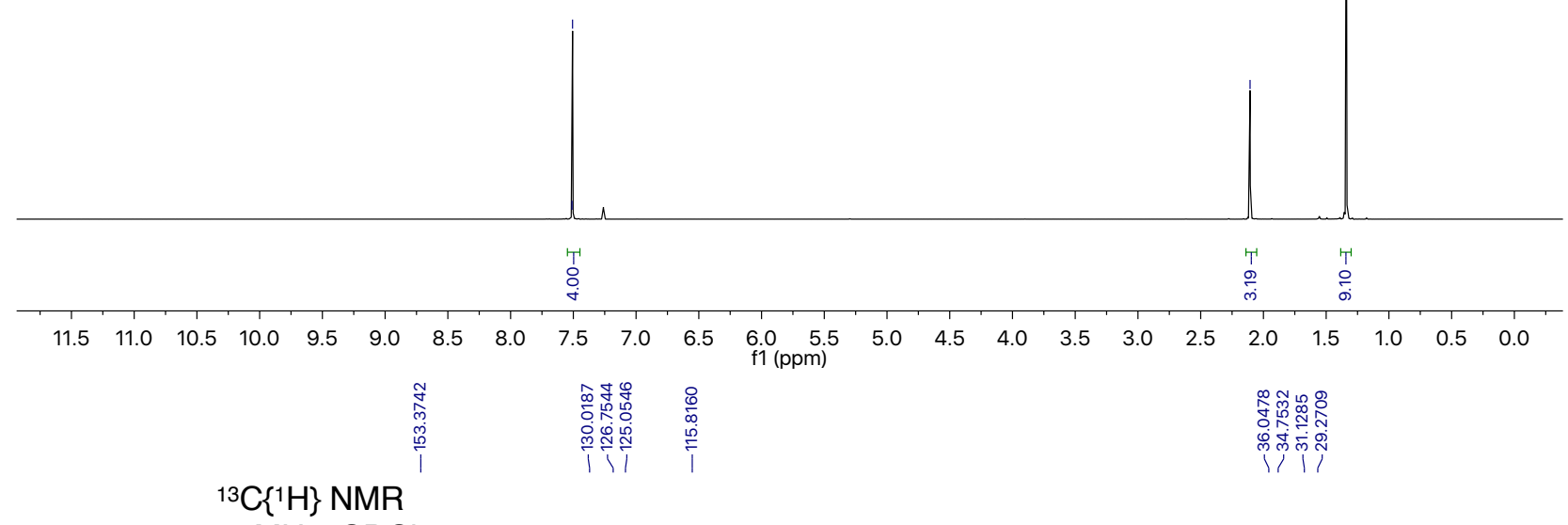
$100 \mathrm{MHz}, \mathrm{CDCl}_{3}$<smiles>CC(C)(C)c1ccc(C(C)(C#N)C#N)cc1</smiles>

S27

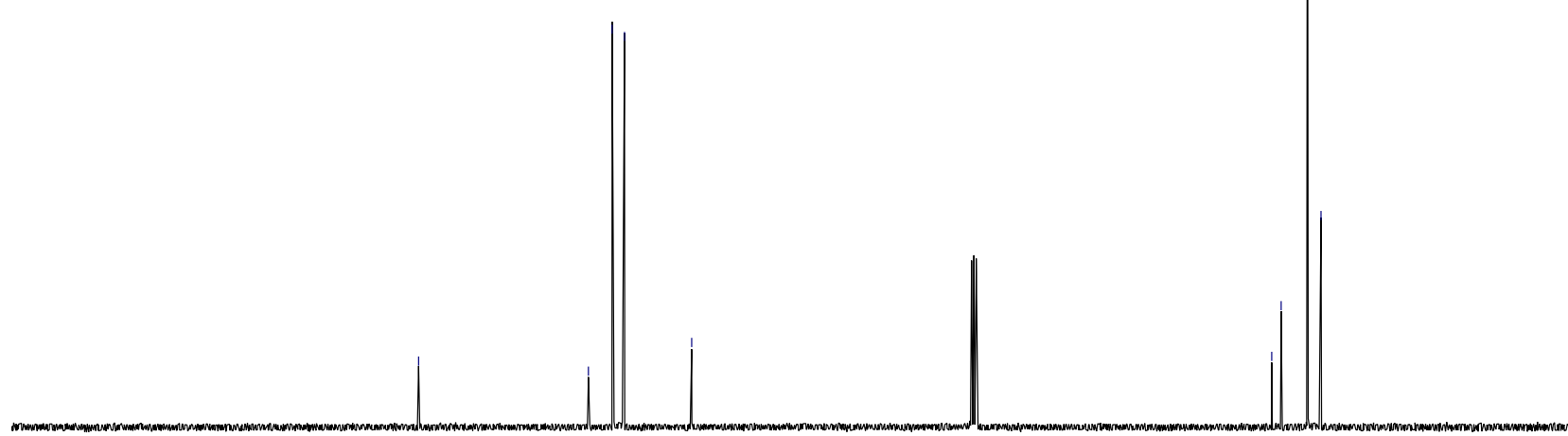

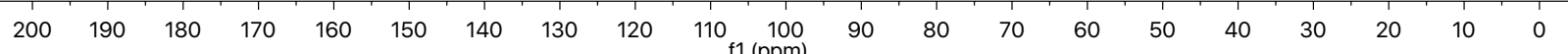




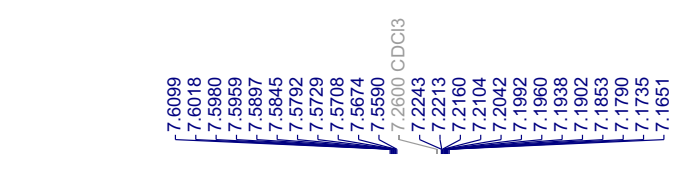

$1 \mathrm{H}$ NMR

$400 \mathrm{MHz}, \mathrm{CDCl}_{3}$<smiles>CC(C#N)(C#N)c1ccc(F)cc1</smiles>

S28

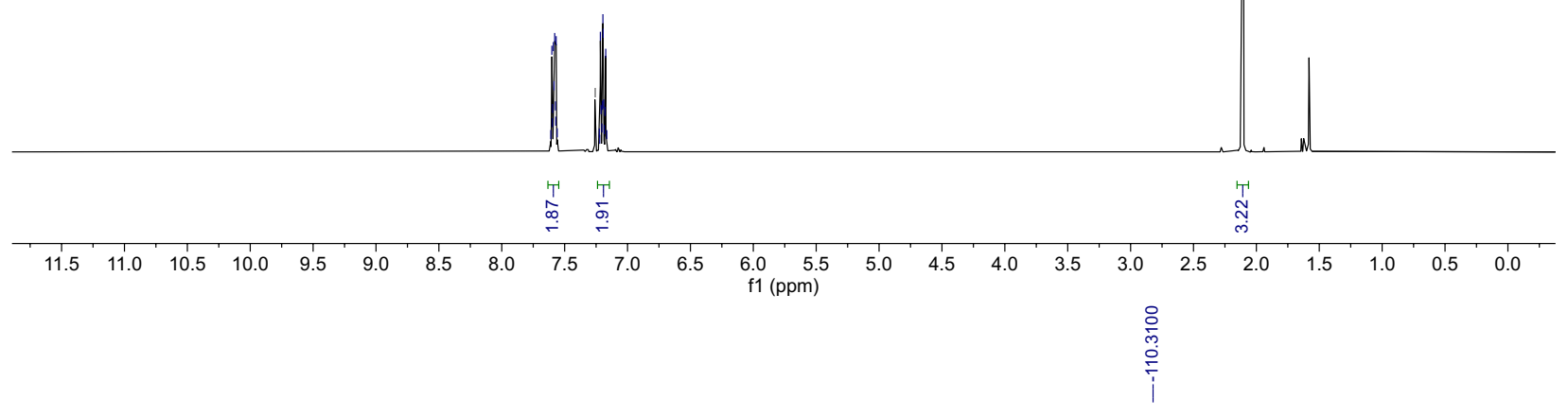

${ }^{19} \mathrm{~F}\left\{{ }^{1} \mathrm{H}\right\} \mathrm{NMR}$ $376 \mathrm{MHz}, \mathrm{CDCl}_{3}$<smiles>CC(C#N)(C#N)c1ccc(F)cc1</smiles>

S28

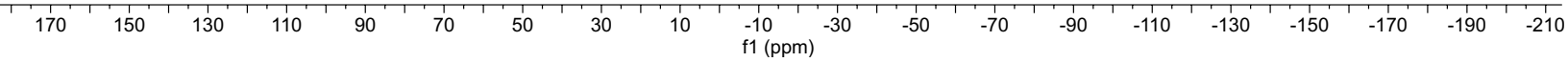




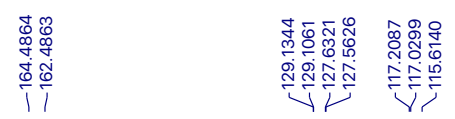

${ }^{13} \mathrm{C}\left\{{ }^{1} \mathrm{H}\right\}$ NMR

$125 \mathrm{MHz}, \mathrm{CDCl}_{3}$

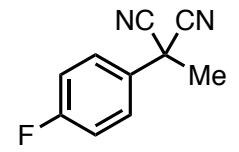

S28

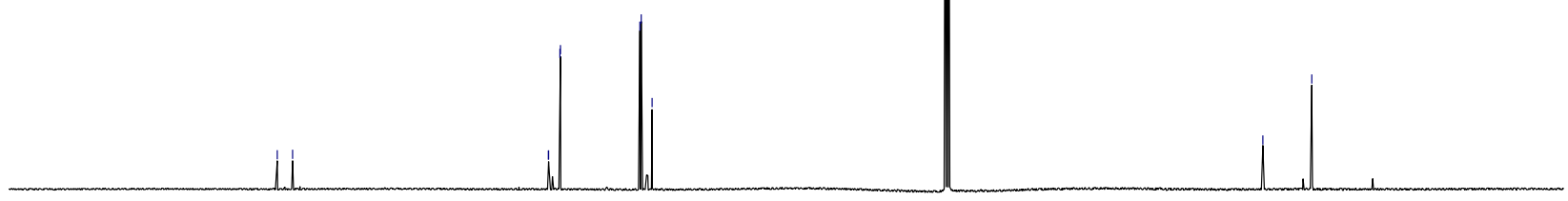

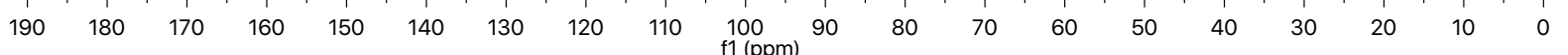




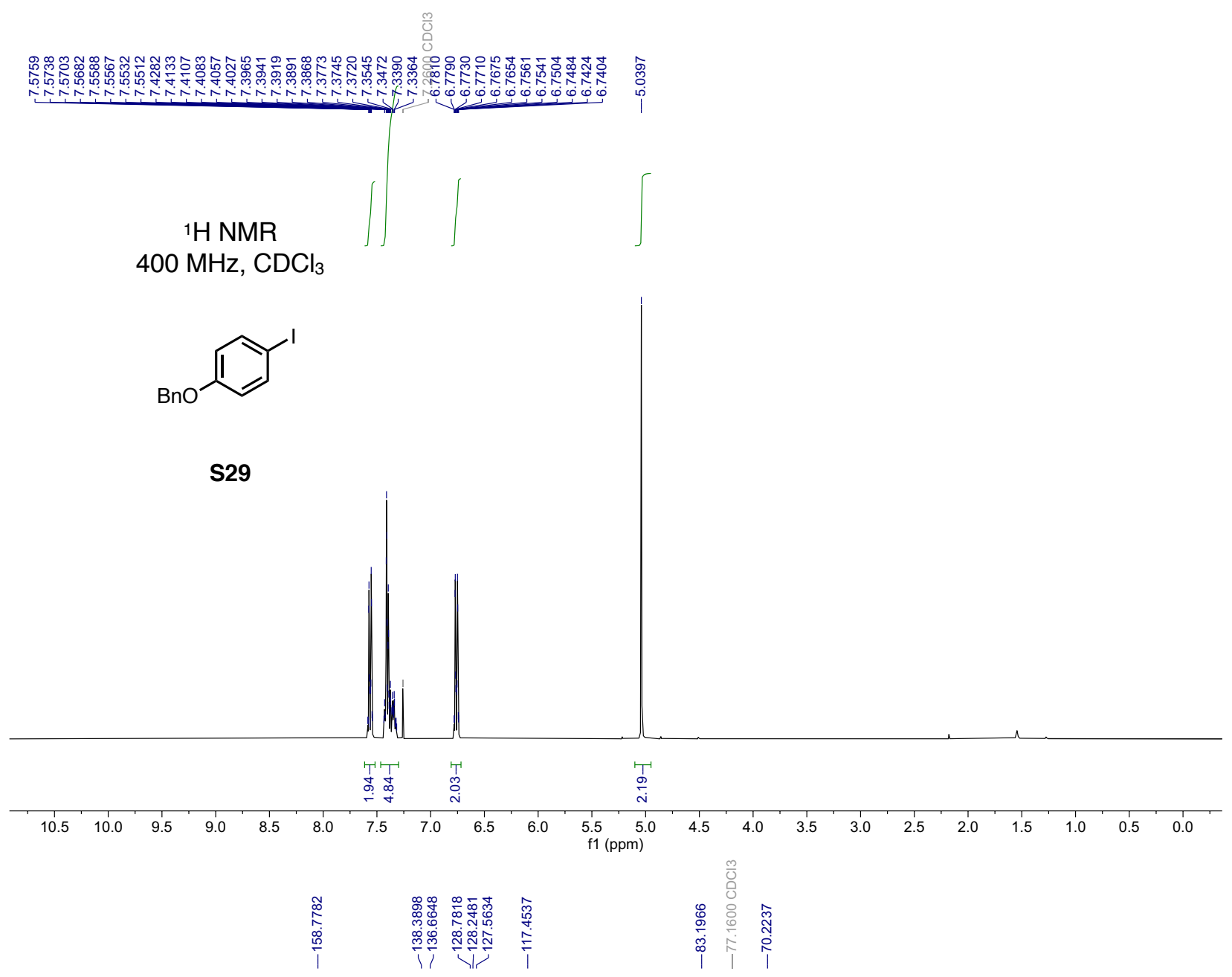

${ }^{13} \mathrm{C}\left\{{ }^{1} \mathrm{H}\right\}$ NMR $100 \mathrm{MHz}, \mathrm{CDCl}_{3}$<smiles>Oc1ccc(Br)cc1</smiles>

S29

120 $10 \begin{gathered}100 \\ \mathrm{f} 1(\mathrm{ppm})\end{gathered}$ 

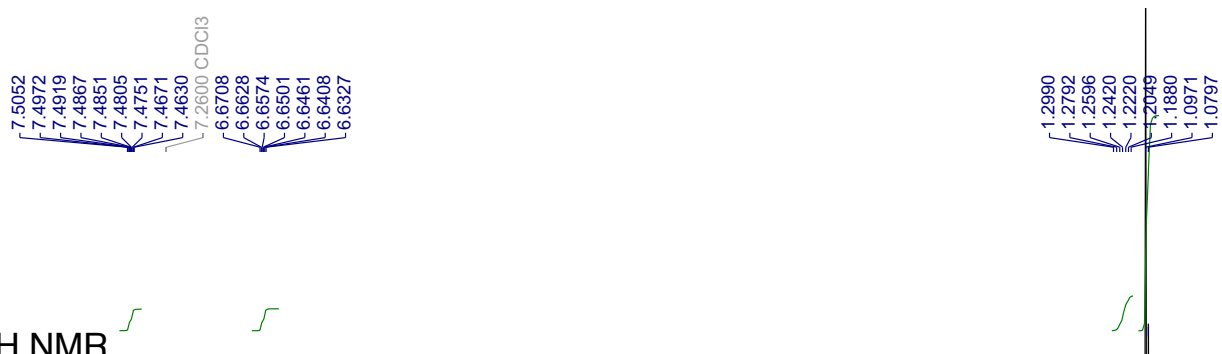

${ }^{1} \mathrm{H}$ NMR

$400 \mathrm{MHz}, \mathrm{CDCl}_{3}$

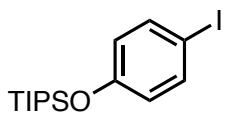

S30

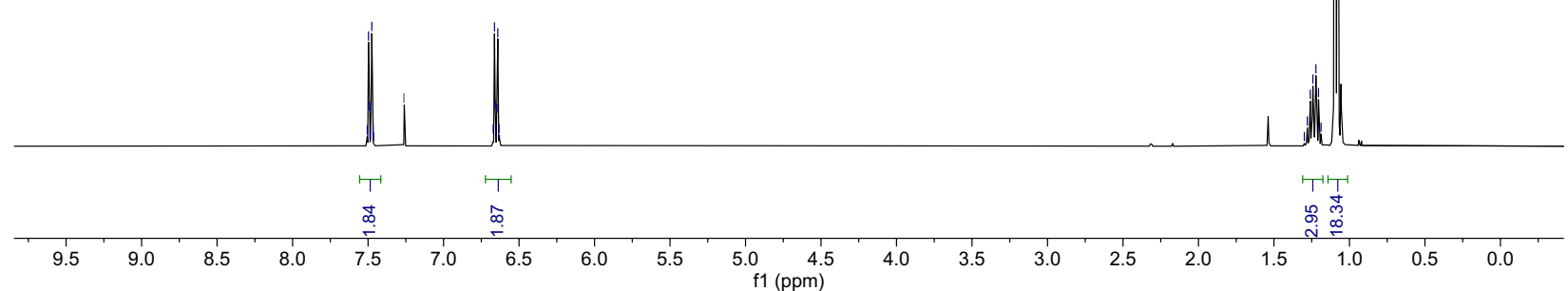

${ }^{13} \mathrm{C}\left\{{ }^{1} \mathrm{H}\right\} \mathrm{NMR}$

$100 \mathrm{MHz}, \mathrm{CDCl}_{3}$

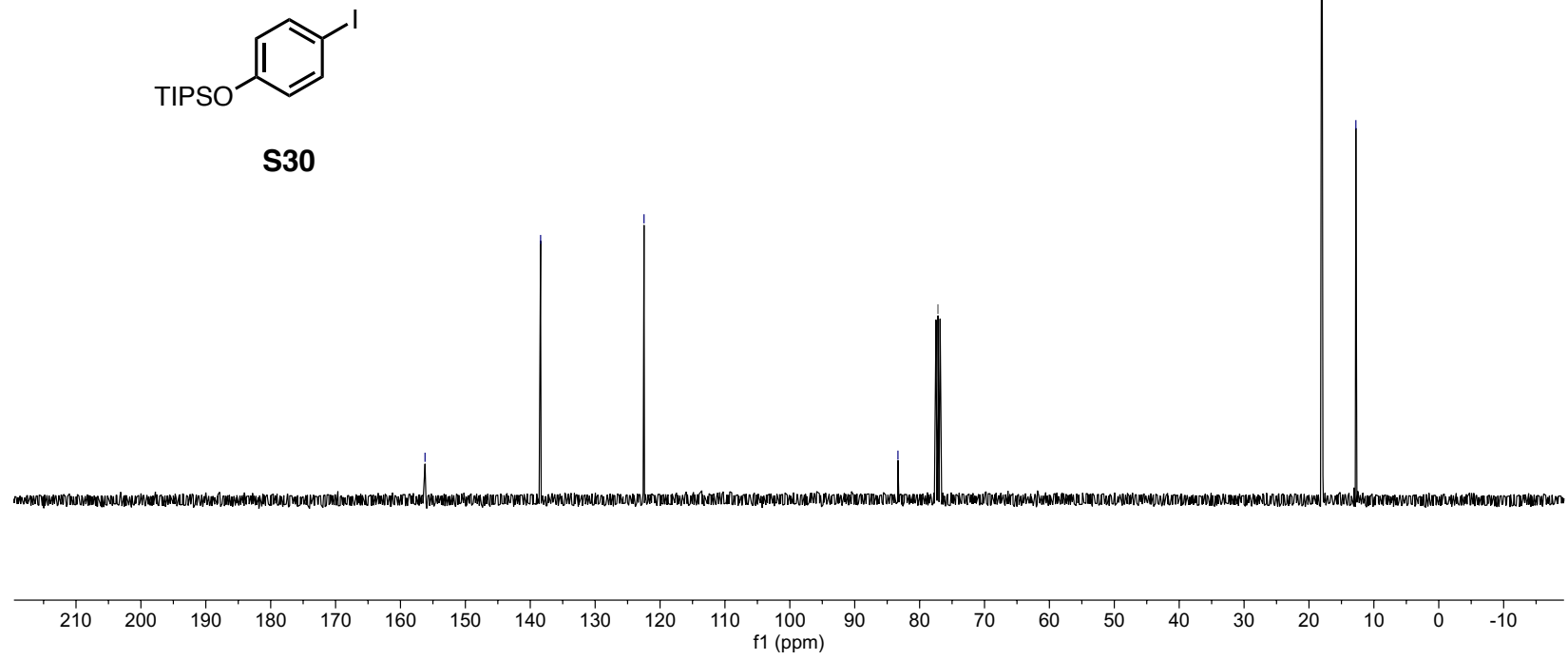

S30

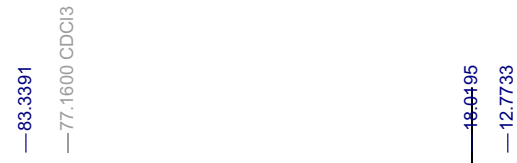




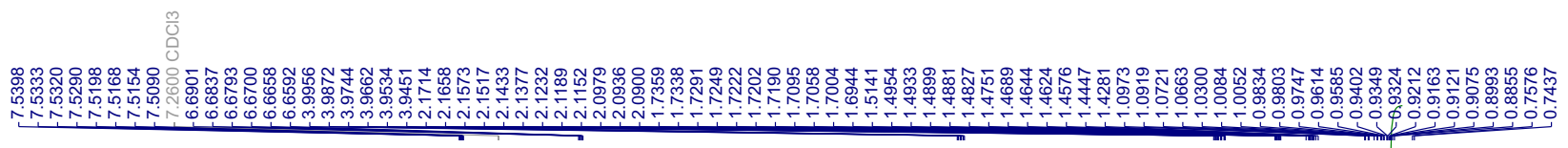

${ }^{1} \mathrm{H}$ NMR

$500 \mathrm{MHz}, \mathrm{CDCl}_{3}$<smiles>CC1CCC(P)[C@@H](Oc2ccc(I)cc2)C1</smiles>

S31

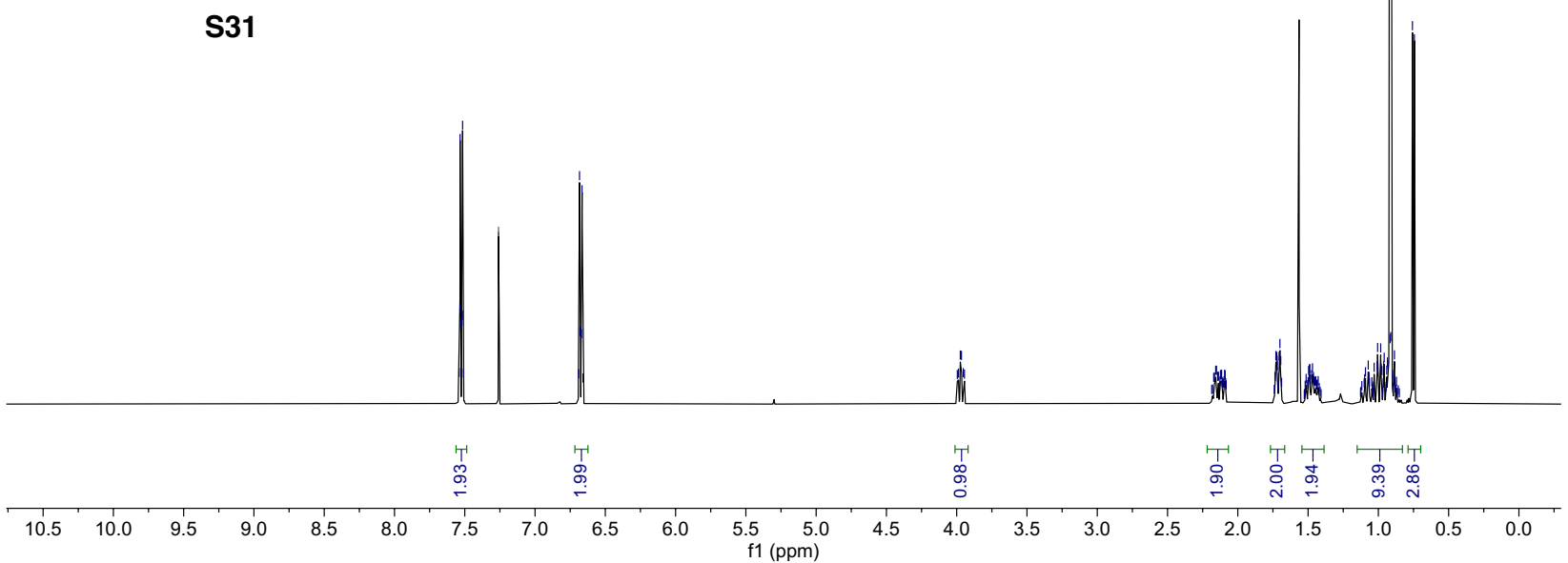

${ }^{13} \mathrm{C}\left\{{ }^{1} \mathrm{H}\right\}$ NMR

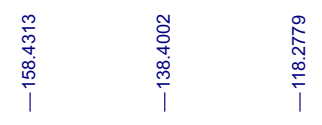
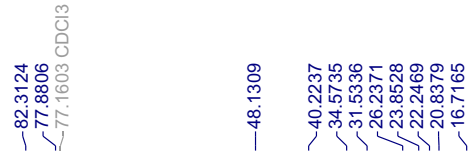

$125 \mathrm{MHz}, \mathrm{CDCl}_{3}$<smiles>CC1CCC(P)[C@@H](Oc2ccc(I)cc2)C1</smiles>

S31

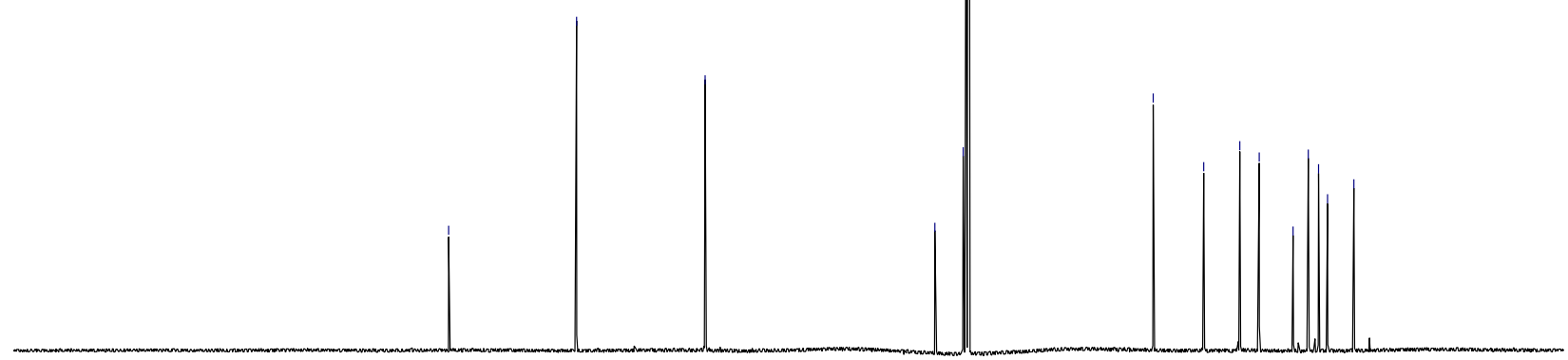

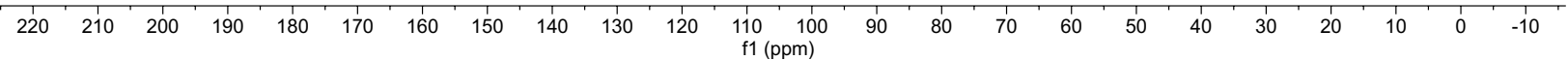




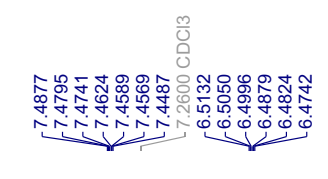

${ }^{1} \mathrm{H}$ NMR

$400 \mathrm{MHz}, \mathrm{CDCl}_{3}$

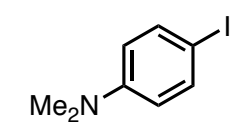

S33

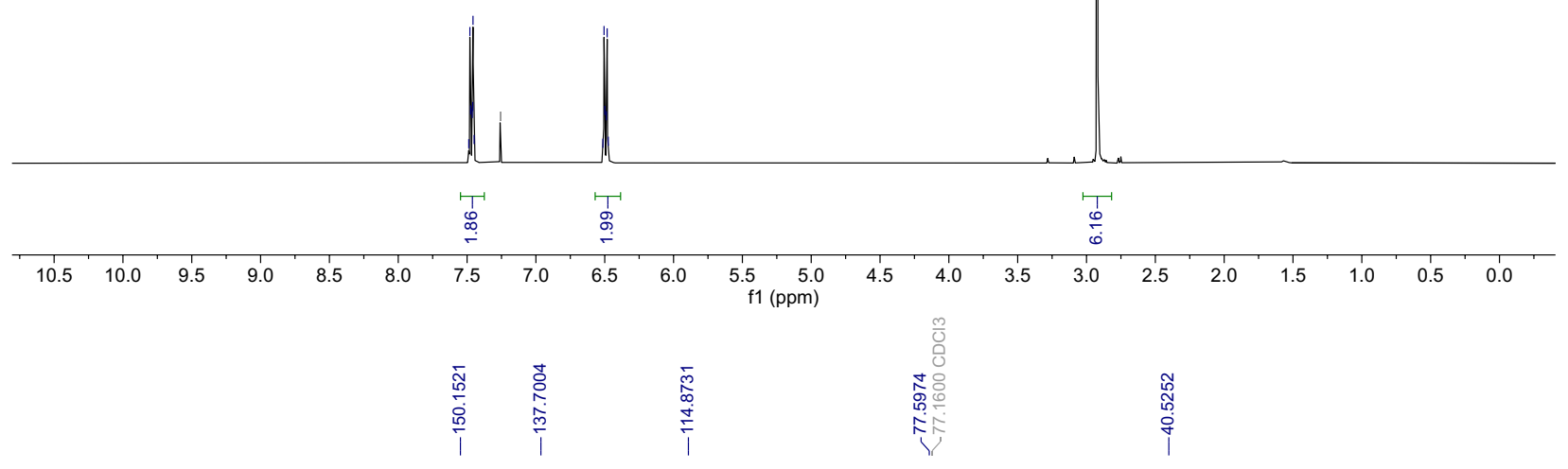

${ }^{13} \mathrm{C}\left\{{ }^{1} \mathrm{H}\right\}$ NMR

$100 \mathrm{MHz}, \mathrm{CDCl}_{3}$<smiles>CNc1ccc(I)cc1</smiles>

S33

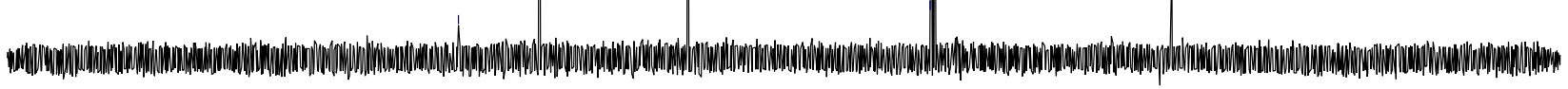

\begin{tabular}{lllllllllllllllllllllll}
\hline 10 & 200 & 190 & 180 & 170 & 160 & 150 & 140 & 130 & 120 & 110 & $\begin{array}{c}100 \\
1\end{array} 10$ & 80 & 70 & 60 & 50 & 40 & 30 & 20 & 10 & 0 & -10 & 10
\end{tabular}




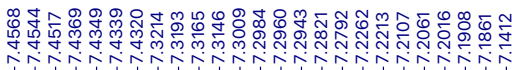

$1 \mathrm{H}$ NMR

$400 \mathrm{MHz}, \mathrm{CDCl}_{3}$<smiles></smiles>

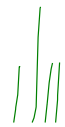

S34

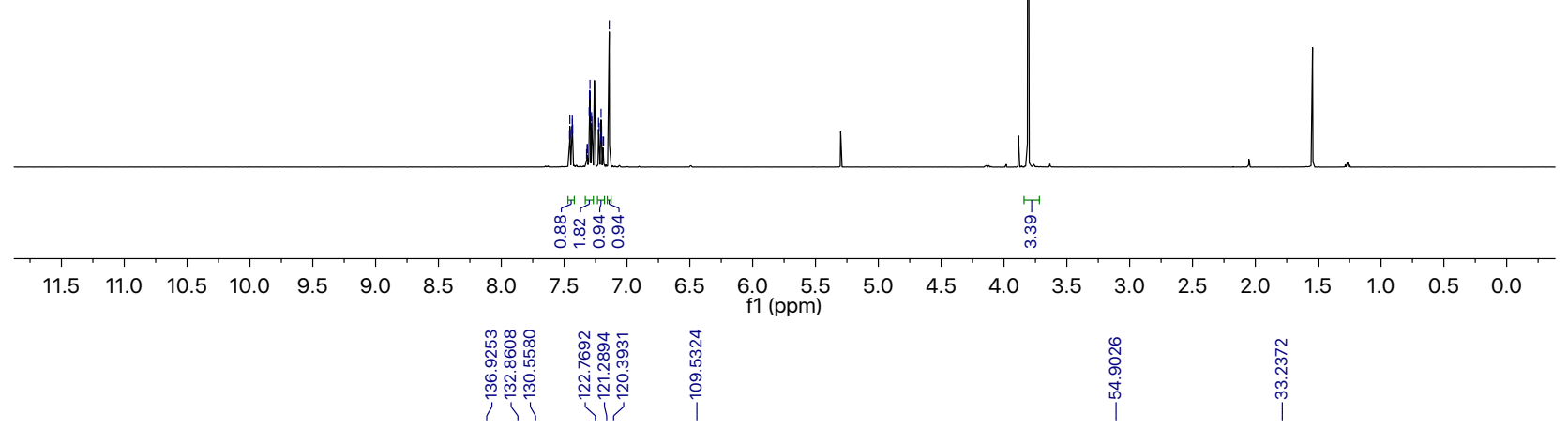

${ }^{13} \mathrm{C}\left\{{ }^{1} \mathrm{H}\right\}$ NMR

$100 \mathrm{MHz}, \mathrm{CDCl}_{3}$<smiles>O=[N+]([O-])c1cn(I)c2ccccc12</smiles>

S34

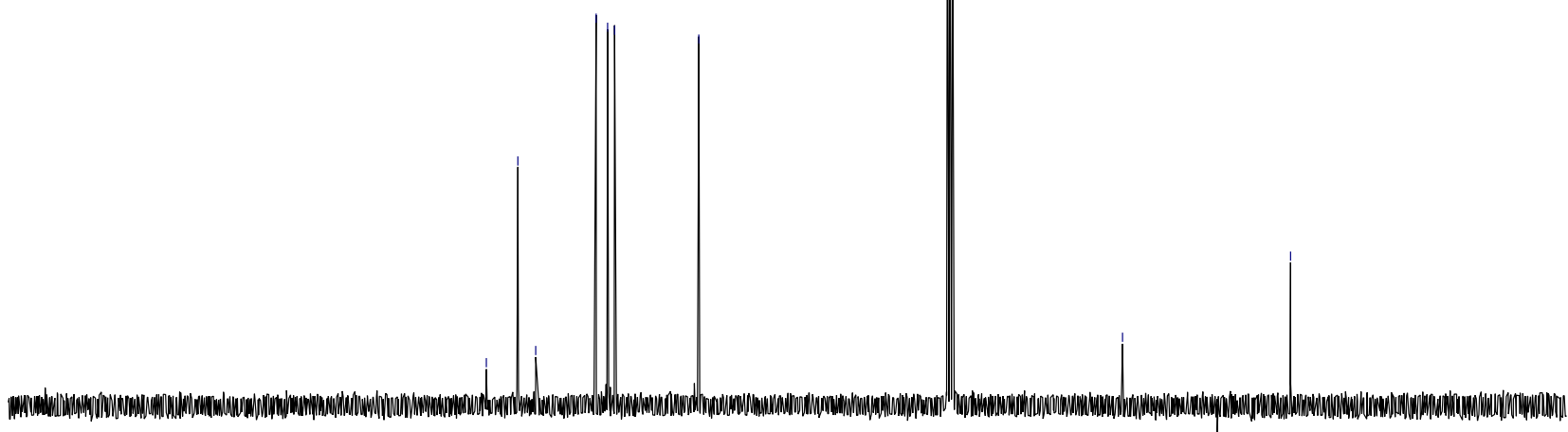

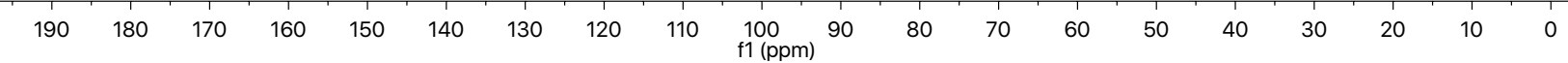




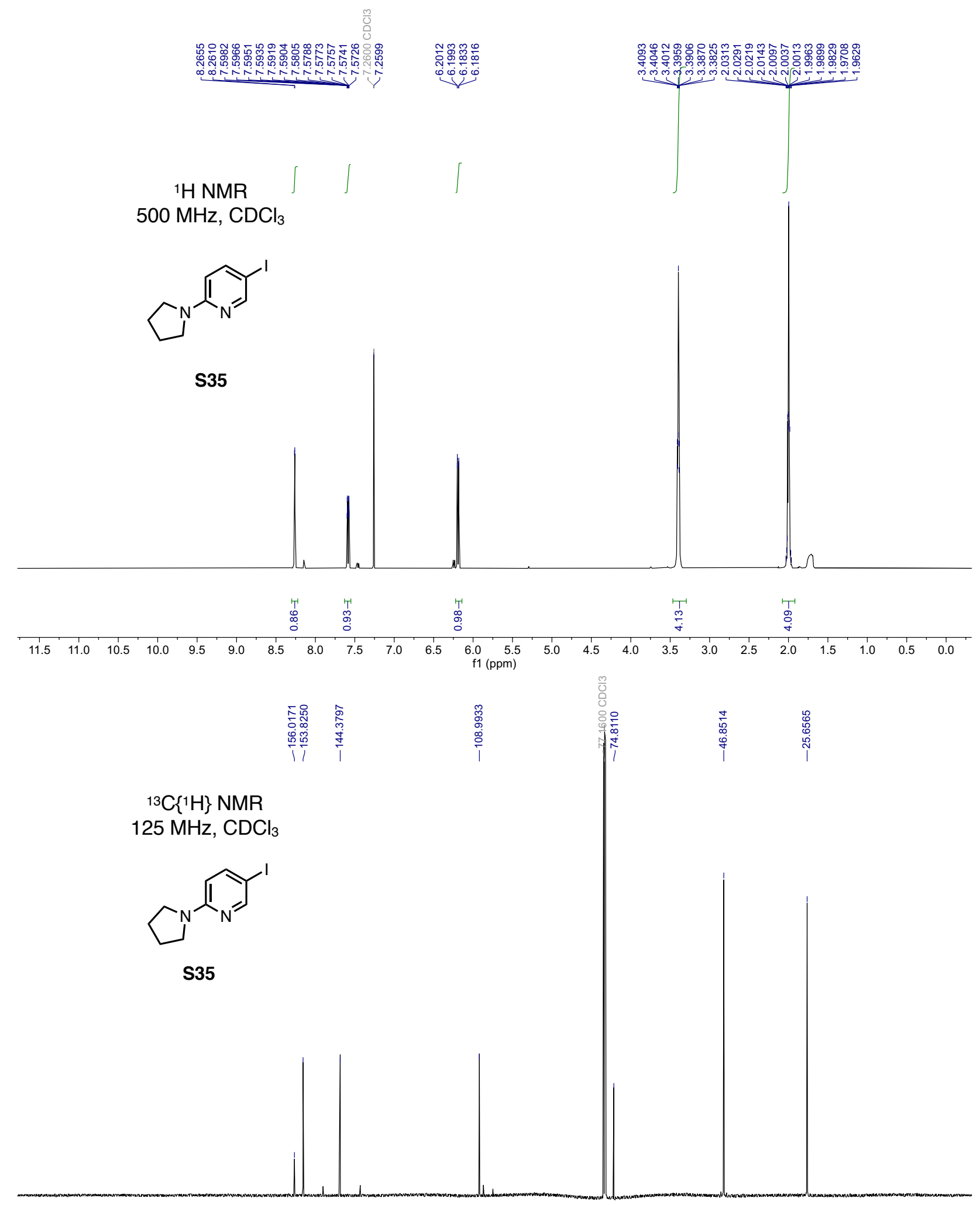

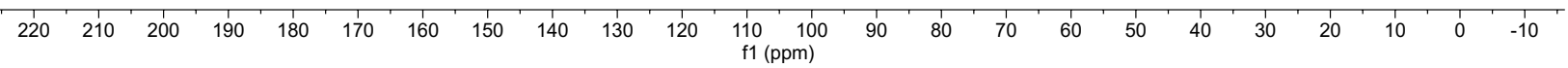

